Eneida de Goes Leal

\title{
TEORIA FonOLÓGICA E VARIAÇÃO: A QUEDA DE SílabA EM CAPIVARI E EM CAMPINAS
}

(Versão corrigida)

Tese apresentada junto ao Departamento de Linguística da Faculdade de Filosofia, Letras e Ciências Humanas da Universidade de São Paulo para obtenção do título de Doutora em Linguística.

Orientadora: $\quad$ Prof $^{\mathrm{a}} \mathrm{Dr}^{\mathrm{a}}$ Raquel Santana Santos Coorientador: Prof Dr Emilio Gozze Pagotto 
Unstable condition / A symptom of life In mental and environmental change / Atmospheric disturbance The feverish flux / Of human interface and interchange

The impulse is pure / Sometimes our circuits get shorted By external interference / Signals get crossed And the balance distorted / By internal incoherence

A tired mind become a shape-shifter / Everybody need a mood lifter Everybody need reverse polarity / Everybody got mixed feelings About the function and the form / Everybody got to deviate from the norm

An ounce of perception / A pound of obscure Process information at half speed / Pause, rewind, replay Warm memory chip / Random sample hold the one you need

Leave out the fiction / The fact is this friction Will only be worn by persistence / Leave out conditions Courageous convictions / Will drag the dream into existence

A tired mind become a shape-shifter / Everybody need a soft filter

Everybody need reverse polarity / Everybody got mixed feelings About the function and the form / Everybody got to elevate from the norm

Everybody got mixed feelings / Everybody got mixed feelings Everybody got to deviate from the norm / Everybody got to deviate from the norm Everybody got to elevate from the norm / Everybody got to elevate from the norm

Everybody got to elevate from the norm

Everybody got to evelate from the norm

Everybody got to escalate from the norm/Everybody got to elevate

Everybody got to elevate from the norm

Everybody got to deviate from the nooorm Everybody got to deviate from the norm

Lifeson, A.; Lee, G; Peart, N. (1981). Signos Vitais. Moving Pictures. Track 3, Side B. Canada: Anthem. 
Para

Antonio Leal (in memorian), Gloria Ma de Goes Leal, Belinda de Goes Leal (anjos terrestres) 


\section{Agradecimentos}

Depois de quatro anos, terminar de escrever uma tese é um momento de muita alegria. Devo isto (e mais) à minha Orientadora, Prof ${ }^{a} r^{a}$ Raquel Santana Santos, com quem tanto aprendi e aprendo. Agradeço à Raquel pelo apoio, pela segurança transmitida, pelo contato, pela didática eficiente e direta. Dizem que a pupila deve superar a mestra: é com muito orgulho que serei sempre sua Eterna Aluna! Que Deus Ihe dê em dobro e a abençoe hoje e sempre. Brigada, Raquel!

Agradeço ao Prof Dr Emilio Gozze Pagotto, meu co-orientador, por me passar de maneira tão fácil, simples o conhecimento sociolinguístico (tão legal aprender a jogar no Varbrul). Agradeço também as reuniões (inclusive as skypianas de além-mar).

Agradeço muito à minha família, aos meus pais e irmã, por serem/estarem sempre presente. À mamãe e Bê, agradeço demais pelas presenças constantes ao longo da escrita desta tese. (Vamo vê um filminho agora?)

Agradeço aos Profs Drs Ester Mirian Scarpa, Gisela Collischonn, Luciani Tenani e Ronald Beline por comporem minha banca de defesa, um grande privilégio que tive. Agradeço muito todos os comentários, que seguirão comigo em minha vida acadêmica. Aos Profs Drs Emilio Gozze Pagotto e Ronald Beline, agradeço todos os comentários muito proveitosos na minha qualificação de doutorado.

Agradeço às minhas irmãs de coração, Dimaura e Babi, pelo apoio e presença constantes, mesmo com distância física. (Ai, que saudá dos 6).

Agradeço ao Prof Dr Dr Everardo por me ajudar/ensinar tanto. Agradeço o ombro tão perto, tão amigo... Agradeço por me ajudar a passar pelas aventuras da vida (como a escrita desta tese, por exemplo), cheias de tantos altos e baixos!

Agradeço ao Prof Dr Bruce Hayes por ter me recebido na University of California, Los Angeles.

Agradeço à CAPES pelas bolsas de doutorado e de sanduíche - sem elas, impossível. 
Agradeço à $\operatorname{Prof}^{\mathrm{a}} \mathrm{Dr}^{\mathrm{a}}$ Esmeralda V. Negrão e Evani Viotti, pela grande ajuda quando saí no sanduíche.

Érica, Ben-Hur e Robson, sempre ali! Muito obrigada!

Agradeço à Alinha, ao Bruno B. e à Symare pelo apoio enquanto estive longe da minha terrinha. Vocês foram fundamentais! Agradeço também à Mare, Netão e Vardo pelas boas e velhas gargalhadas.

A Rodolfo e família; à Letícia e família, agradeço por... existirem...

Agradeço a Rodrigo, à Simone e, principalmente, à Clarinha por me alegrarem tanto e por "estarem" comigo em Lalaland.

Agradeço à Maria Angela por todos os cafés "filosóficos" que tomamos, todos que gostaríamos de ter tomado e por todos os muitos que ainda vamos tomar.

Agradeço à Fer Consoni, Livia, Marquinhus Lunguinho, Renatchinha e Aline Cruz por... serem meus amigos! Tão bom quando a gente se encontra!

Agradeço à Samara por me proporcionar momentos muito legais extra-sanduíches que ralouim! (Whassup, guria?)

To the Longs (Kevin and Megan), I am truly thankful for finding you guys. I thank you guys for becoming my family. Come to Brazil RIGHT now. Miss you.

Agradeço a todos os informantes (mais do que 48, que são os que estão nesta tese) que me ajudaram tanto, que me deixaram entrar em suas casas e ambientes de trabalho, dispostos a conversar!

Agradeço ao Allan, à Andressa, à Maitê, à Melanie A., à Raiça, à Uila e à Vanessa pela grande ajuda com as transcrições.

Agradeço à Aline, Babi, Livia e Matchizinho por estarem na defesa. Agradeço às suas presenças constantes, tanto na minha vida pessoal quanto na profissional.

Agradeço à família Freitas Leal pela presença na defesa, representada pelo tio Ditinho. Que alegria!

Agradeço à presença-surpresa de Marcia (CiaVi), à sua amizade, ao seu carinho e apoio. Agradeço à Fernanda Pimenta Falciroli pela presença não física na minha defesa. Agradeço à CiaVi e Pincesa por serem.

À Teca, agradeço cada apoio, cada estímulo, cada interesse, cada palavra. Se 
Galileu fosse linguista, ele diria: "A linguística é a equação com qual Deus multiplicou o universo."

Por fim, mas nem um pouquinho sem importância, agradeço à tia Má, Harol, tia Ana, tio Nenê, tio Lamar, vô Bene, pelos fins de semana deliciosos, de risos e brincadeiras, que tanto me ajudaram a "espairecer" e seguir escrevendo esta tese. Tantas vezes desopilei o fígado, como diria Tica! 


\section{Resumo}

Esta tese trata da comparação dos dialetos de Capivari e de Campinas, com o objetivo de verificar se há uma mesma regra de queda de sílaba nas duas cidades ou se cada um dos dialetos tem características diferentes para o processo.

O trabalho tem base na teoria fonológica gerativista e na sociolinguística variacionista, analisando variáveis linguísticas e sociais. As interferências linguísticas analisadas foram os segmentos do contexto de queda de sílaba (com a geometria de traços, cf. Clements \& Hume 1995), as estruturas das duas sílabas do contexto de apagamento (cf. Selkirk 1982), a estrutura métrica (Selkirk 1984, Hayes 1995), a prosódia (Nespor \& Vogel 1986) e, da palavra sujeita à queda, verificamos o número de sílabas e a frequência de uso. Quanto às variáveis sociais, analisamos a escolaridade, o gênero, a faixa etária e a cidade dos informantes.

No nível segmental, os resultados apontam que a igualdade dos segmentos não interfere em Capivari, mas há uma interferência em Campinas: os resultados apontam que não é a igualdade do conteúdo das sílabas que é importante para a aplicação do processo, mas sim as características da primeira sílaba (aquela sujeita ao apagamento). Com relação às consoantes, pudemos observar que coronais favorecem e nasais desfavorecem, em ambos os dialetos - e de modo quase idêntico. No entanto, há uma grande diferença na implementação no contexto consonantal com dorsais: o processo é favorecido em Capivari e desfavorecido em Campinas. No que concerne às vogais, pudemos verificar que há diferenças nas duas cidades, pois sequências [coronal + coronal] e [dorso-labial + coronal] são neutras ao processo em Capivari e favorecem em Campinas. Ainda para as vogais, o que parece importar não é a igualdade das duas sílabas, mas sim o traço da vogal sujeita ao apagamento, assim como apontam os resultados para a igualdade do conteúdo das sílabas (em Campinas).

No nível suprassegmental, para as estruturas das sílabas, as cidades diferem se a primeira sílaba for uma CV seguida de outros tipos de estruturas: há uma neutralidade em Capivari e em Campinas há um favorecimento. Com relação a número de sílabas, o 
tamanho da palavra importa para Capivari (quanto maior a palavra, há um leve favorecimento), enquanto que esta variável não foi selecionada em Campinas.

No âmbito lexical, foi visto que a frequência de uso da palavra sujeita à queda importa para o dialeto de Campinas (palavras de frequência média de uso favorecem levemente; em palavras de frequência alta, há uma neutralidade; e palavras de baixa frequência desfavorecem um pouco). Uma vez que esta variável não foi selecionada em Capivari, podemos concluir que há uma diferença na queda de sílaba nas duas cidades, com relação à frequência de uso da primeira palavra.

Assim, podemos afirmar que há diferenças segmentais, suprassegmentais e lexicais nas duas cidades; só há semelhanças com relação à Cavidade Oral das Consoantes sem distinguir a nasalidade entre as variantes (pois esta variável não foi selecionada em nenhuma das cidades), e com relação à Prosódia (os resultados foram muito parecidos: há um leve favorecimento entre duas frases fonológicas, neutralidade entre grupos clíticos e um pouco de desfavorecimento entre frases entonacionais). 


\section{Abstract}

This dissertation deals with syllable drop in Capivari and Campinas' dialects and the principle aim is to verify whether there is one single phonological rule or two distinct syllable drop rules for both cities.

This work is based on generative phonological theory and variacionist sociolinguistics, hence we analyze both linguistic and social variables. The linguistic factors analyzed were the segments (feature geometry, cf. Clements \& Hume 1995), syllable structure (cf. Selkirk 1982), metrical structure (Hayes 1995), prosody (Nespor \& Vogel 1986), number of syllables, and usage frequency for the first word in the context. As for the social factors, we analyzed the subjects schooling, gender, age, and city.

At segmental level, we have found that it is not important for the segments to be equal in Capivari, and it is in Campinas instead. As for the consonants, coronals are biased, and nasals disfavor the process, in both cities. On the other hand, there is a great difference in consonantal context concerning to dorsals: syllable drop is favored in Capivari and disfavored in Campinas. Considering the vowels, there are differences between the cities, since sequences of [coronal + coronal] and [dorso-labial + coronal] are unbiased in Capivari and favoring in Campinas.

At the suprasegmental level, both the dialects behave differently as for syllable structure if the first one is $\mathrm{CV}$ followed by other types of structures: the process is neutralized in Capivari and there is a favoring effect in Campinas. Regarding number of syllables, the size of the word undergoing the process is important in Capivari (bigger words are slightly biased), and this variable has not been selected in Campinas.

In relation to the lexical level, usage frequency of the first word (subjected to deletion) matters in Campinas (average frequency words slightly favor; high frequency words are unbiased, and low frequency words slightly disfavor). Since this variable was not selected in Capivari, we understand that there is a difference in usage frequency of words between the cities.

Therefore, we can conclude that there are segmental, suprasegmental e lexical 
differences in Capivari and Campinas. There are equal effects in the variable Oral Cavity of Consonants if [nasal] feature is not taken into account (this variable was never selected in the cities), and equal effects in Prosody variable (the results were very similar: the process is a slightly favored between phonological phrases, it is unbiased between clitic groups and it is slightly disfavored between entonational phrases). 


\section{Sumário}

Agradecimentos …….......................................................................................iv

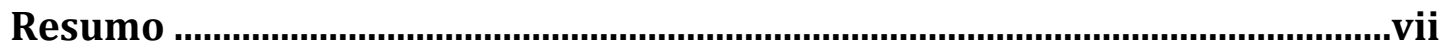

Abstract .................................................................................................

Lista de Tabelas ...................................................................................................xvi

Lista de Gráficos ..................................................................................................

CAPÍTULO I ……...................................................................................................... 1

1. Introdução

1.1. 0 que é a queda de sílaba?

1.2. As cidades: os panoramas sociais e os dialetos ................................................... 4

1.2.1. Formação das cidades e panoramas sociais .............................................................. 5

1.2.2. Os dialetos capivariano e campineiro............................................................................. 7

1.3. 0 quadro teórico e questões a serem respondidas ............................................ 9

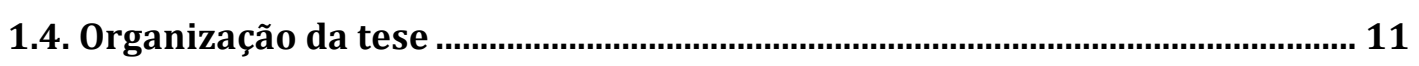

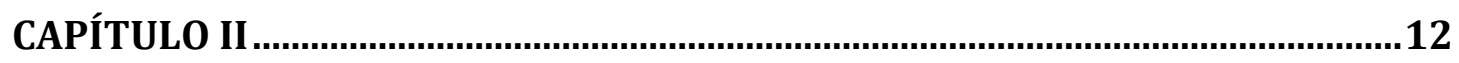

2. 0 quadro teórico ….................................................................................12

2.1. Os modelos variacionista e gerativista: pontos de diálogo ............................. 12

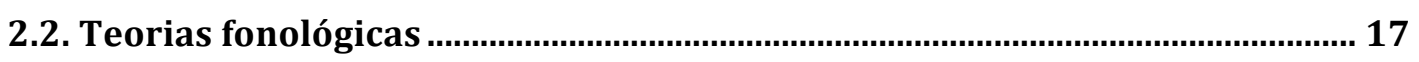

2.2.1. Geometria de traços: a estrutura interna dos segmentos..................................... 17

2.2.2. A estrutura silábica (do português brasileiro) ........................................................... 22

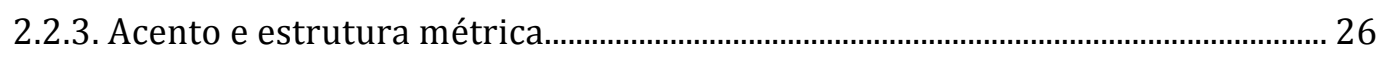

2.2.4. Hierarquia prosódica: a interface fonologia e outros níveis gramaticais ......... 32

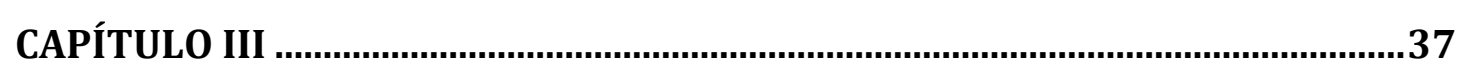

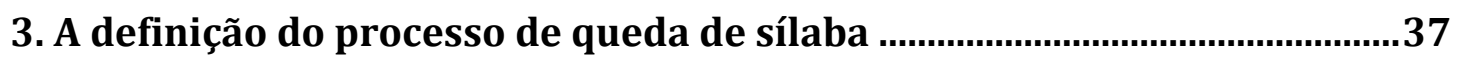

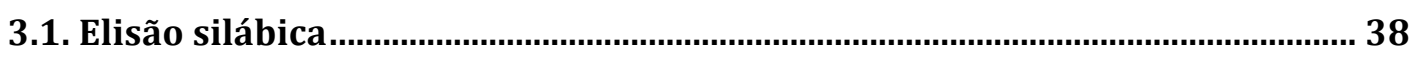

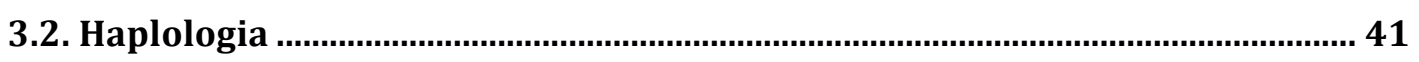

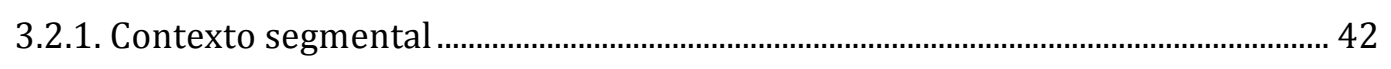

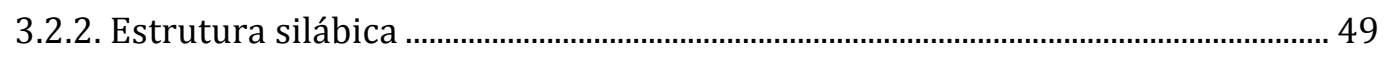




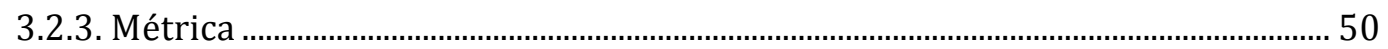

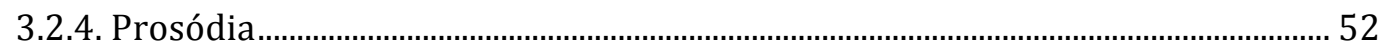

3.3. A análise de Leal (2006): unindo os dois processos .......................................... 53

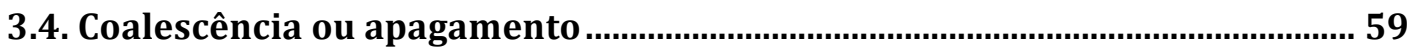

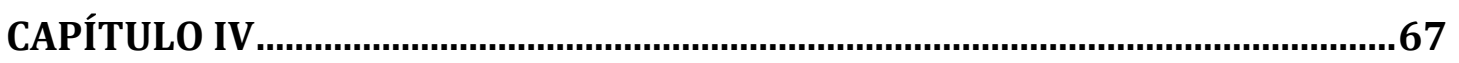

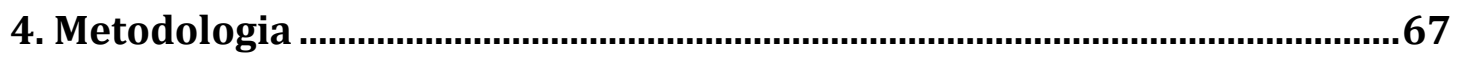

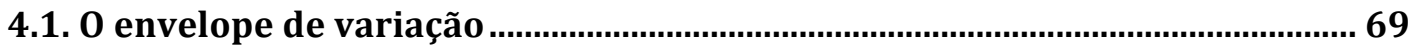

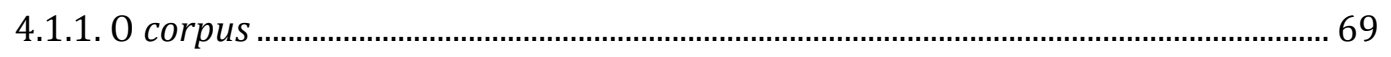

4.1.2. Coleta de dados: as restrições................................................................................... 71

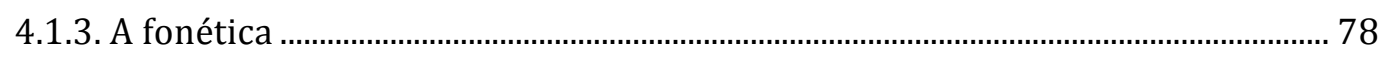

4.1.4. Os grupos de fatores................................................................................................ 81

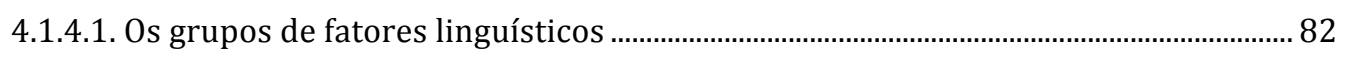

4.1.4.1.1. Contexto segmental............................................................................................ 82

4.1.4.1.1.1. Igualdade de Segmentos nas Sílabas CV ………………………………....... 83

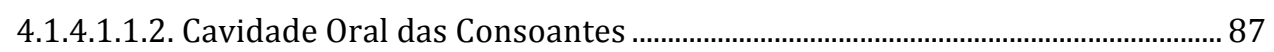

4.1.4.1.1.3. Cavidade Oral das Consoantes com Distinção de [nasal] ............................... 89

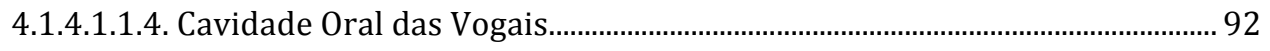

4.1.4.1.2. Estrutura Silábica...................................................................................................... 93

4.1.4.1.3. Métrica .................................................................................................................... 96

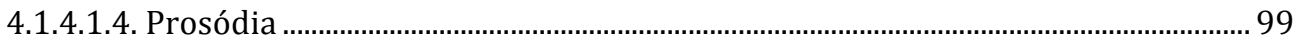

4.1.4.1.5. Número de Sílabas ......................................................................................................101

4.1.4.1.6. Frequência de Uso de Palavras ....................................................................................103

4.1.4.2. Os grupos de fatores sociais ............................................................................................105

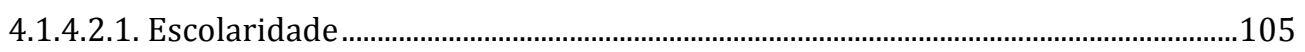

4.1.4.2.2. Gênero.....................................................................................................................106

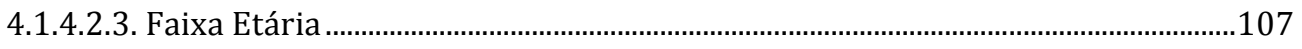

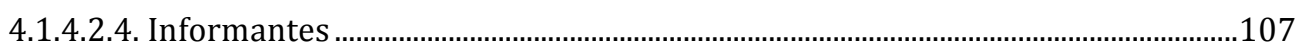

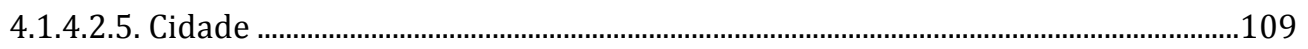

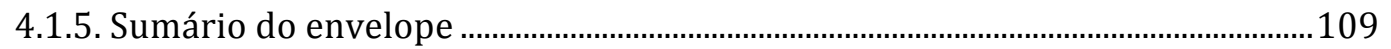

CAPÍTULO V .................................................................................................... 112

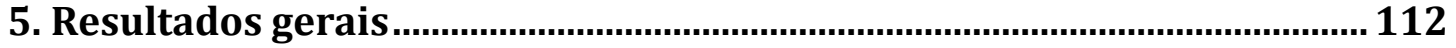

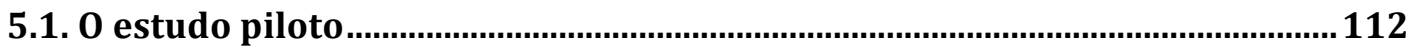

5.1.1. Casos particulares no estudo piloto …………………………………………........115

5.2. Distribuição geral e computação dos dados .......................................................118 


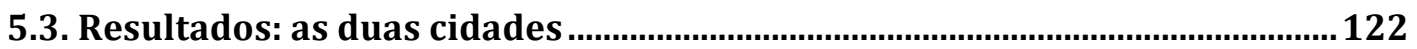

5.3.1. As variáveis linguísticas .....................................................................................122

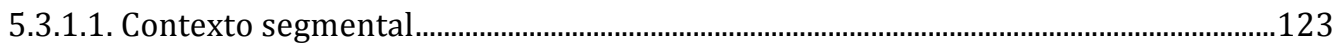

5.3.1.1.1. Igualdade de Segmentos nas Sílabas ........................................................................123

5.3.1.1.2. Cavidade Oral das Consoantes com Distinção de [nasal] ....................................127

5.3.1.1.3. Cavidade Oral das Vogais.........................................................................................130

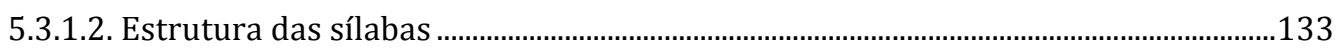

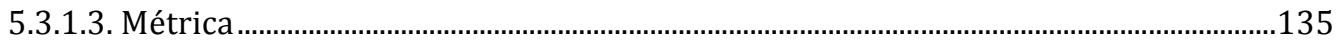

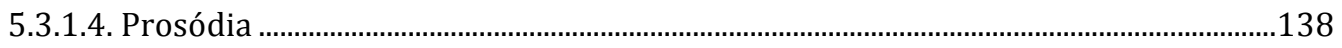

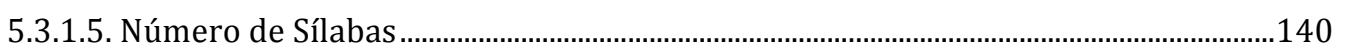

5.3.1.6. Frequência de Uso de Palavras …………………………………………………….....142

5.3.2. As variáveis sociais nas duas cidades .....................................................................143

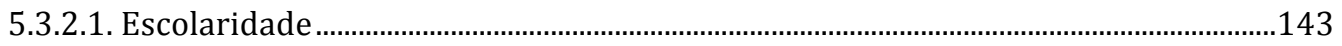

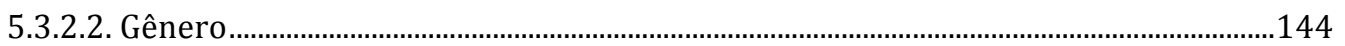

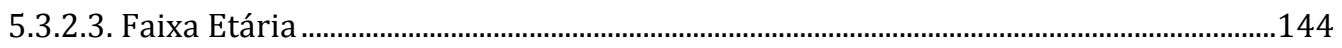

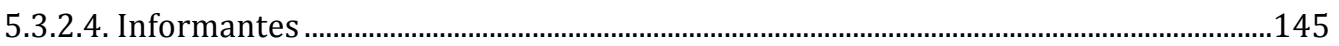

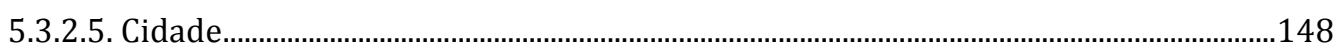

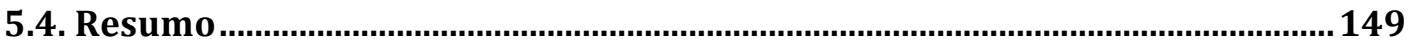

CAPÍTULO VI................................................................................................. 152

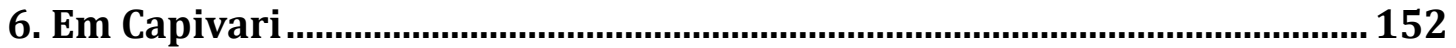

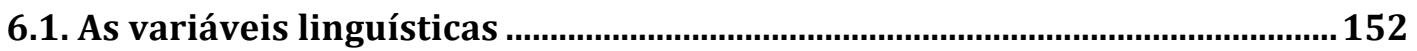

6.1.1. Contexto segmental ............................................................................................153

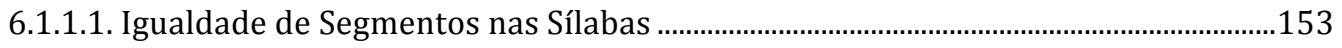

6.1.1.2. Cavidade Oral das Consoantes com Distinção de [nasal] .............................................155

6.1.1.3. Cavidade Oral das Vogais...............................................................................................157

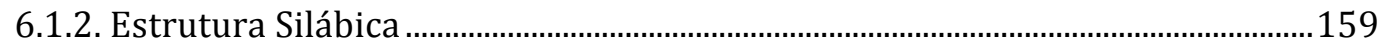

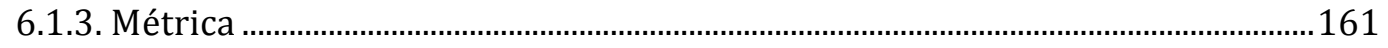

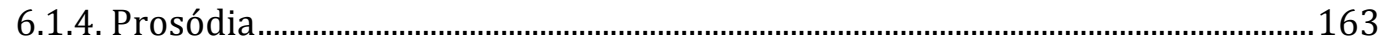

6.1.5. Número de Sílabas ..................................................................................................... 164

6.1.6. Frequência de Uso de Palavras.................................................................................166

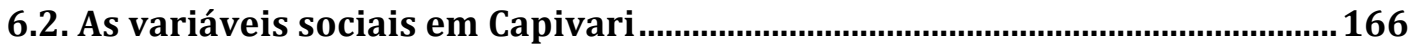

6.2.1. Escolaridade .............................................................................................................. 166

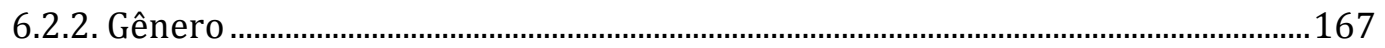

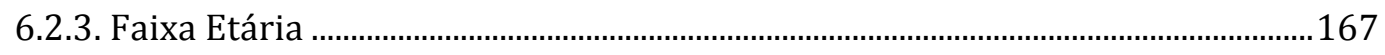

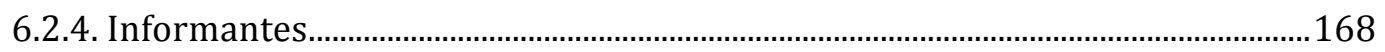




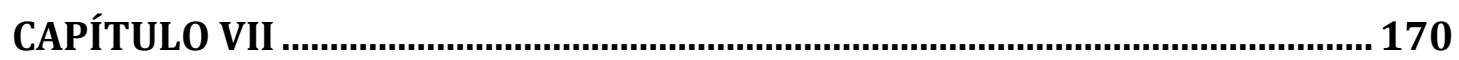

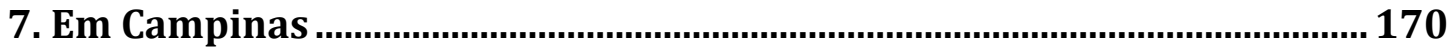

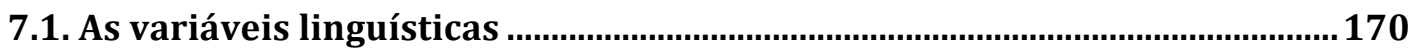

7.1.1. Contexto segmental ............................................................................................ 171

7.1.1.1. Igualdade de Segmentos nas Sílabas .............................................................................171

7.1.1.2. Cavidade Oral das Consoantes com Distinção de [nasal] .............................................172

7.1.1.3. Cavidade Oral das Vogais..............................................................................................174

7.1.2. Estrutura das sílabas............................................................................................ 176

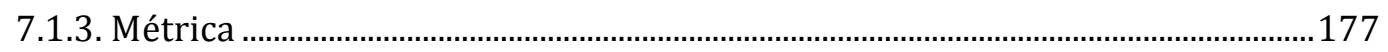

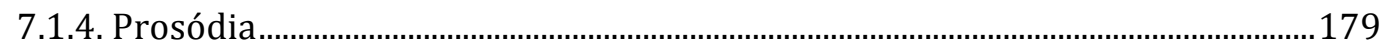

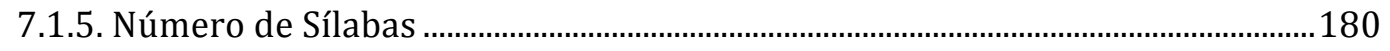

7.1.6. Frequência de Uso de Palavras..................................................................................182

7.2. As variáveis sociais em Campinas ..................................................................183

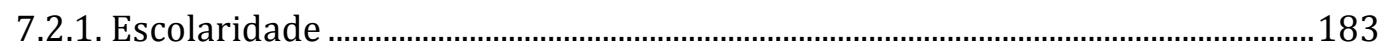

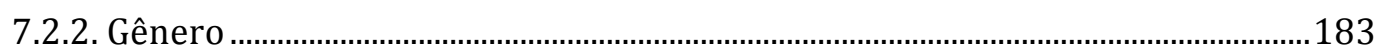

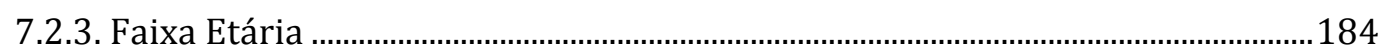

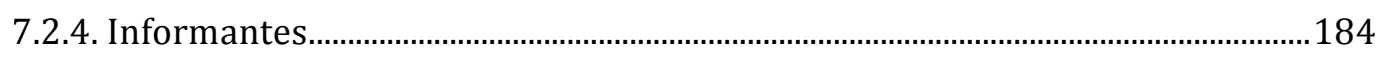

CAPÍTULO VIII.................................................................................................... 186

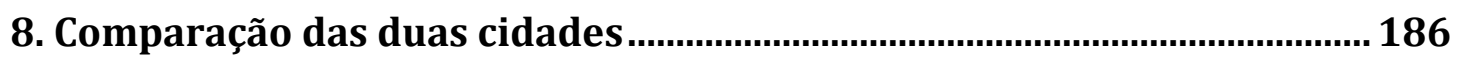

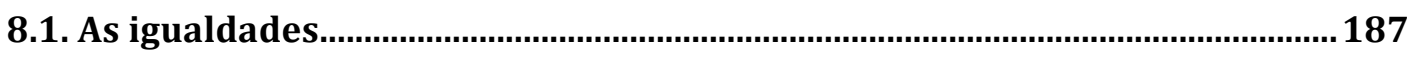

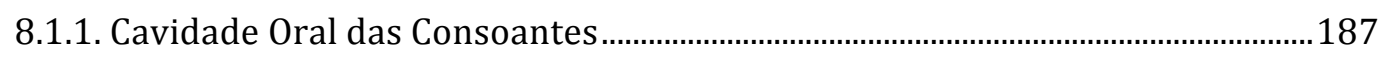

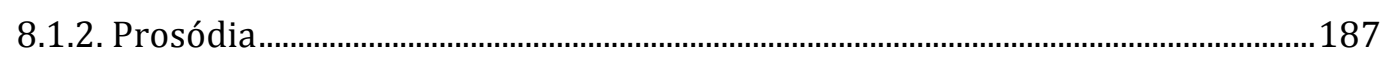

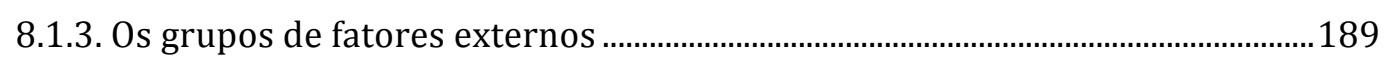

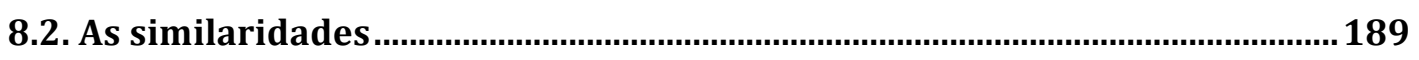

8.2.1. Cavidade Oral das Consoantes com Distinção de [nasal] ......................................189

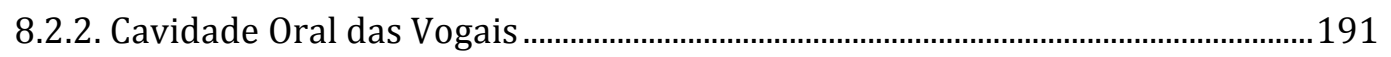

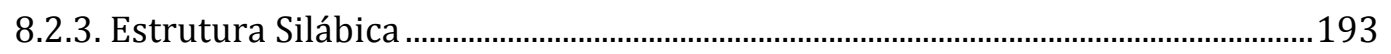

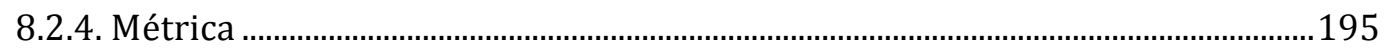

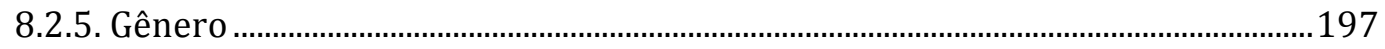

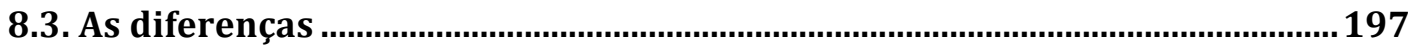

8.3.1. Igualdade de Segmentos.......................................................................................... 198

8.3.2. Número de Sílabas ....................................................................................................199

8.3.3. Frequência de Uso de Palavras..............................................................................20 
8.3.4. Escolaridade e Faixa Etária ......................................................................................20

8.4. Resumo

8.5. Duas cidades, duas regras?

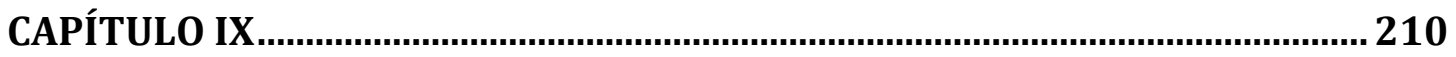

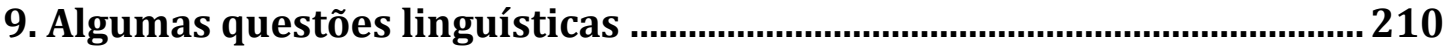

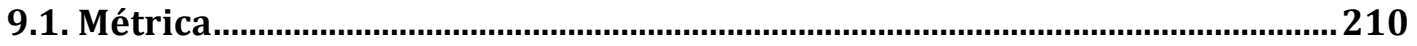

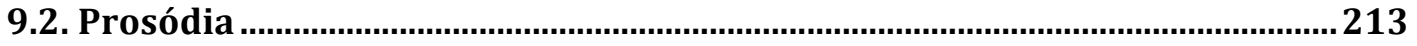

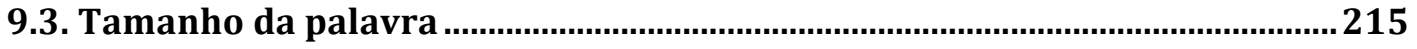

9.4. Estrutura silábica e geometria de traços: Sílabas ou segmentos? .................216

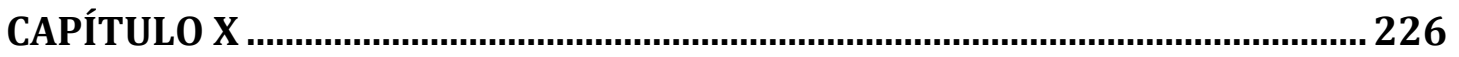

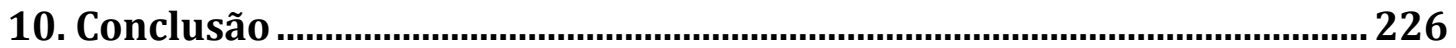

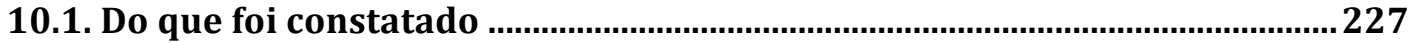

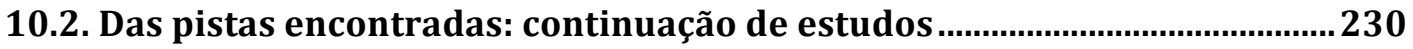

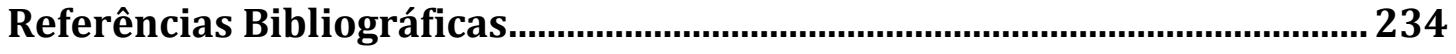

Anexos 


\section{Lista de Tabelas}

Tabela 1 - Comparação dos traços internos de consoantes 39

Tabela 2 - Aplicações de haplologia com relação às consoantes (Pavezi 2006a: 25) - fala espontânea 45

Tabela 3 - Haplologia e tonicidade, adaptado de Tenani (2002: 141). 51

Tabela 4 - Haplologia e domínios prosódicos - dados adaptados de Pavezi (2006a: 52) 52

Tabela 5 - Variáveis externas para a constituição do corpus. 70

Tabela 6 - Aplicações de haplologia em contextos com consoantes [nasal] no teste de Pavezi (2006a: 115). 90

Tabela 7 - Os 48 informantes. 108

Tabela 8 - Sumário do envelope de variação. 110

Tabela 9 - Informantes utilizados na primeira análise 113

Tabela 10 - Frequências das consoantes segundo as cavidades orais 114

Tabela 11 - Aplicações de queda de sílaba com cavidades orais das consoantes diferentes 116

Tabela 12 - Resultados gerais de aplicação de queda de sílaba. 118

Tabela 13 - Semelhanças nos pesos relativos da variável Frequência de Uso das Palavras 120

Tabela 14 - Variável Igualdade de Segmentos (as duas cidades). 124

Tabela 15 - Variável Cavidade Oral das Consoantes com Distinção do Traço [nasal] (as duas cidades) 127

Tabela 16 - Variável Cavidade Oral das Vogais (as duas cidades) …........................... 130

Tabela 17 - Variável Estrutura Silábica (as duas cidades) ......................................... 133

Tabela 18 - Variável Métrica (as duas cidades) ......................................................... 135

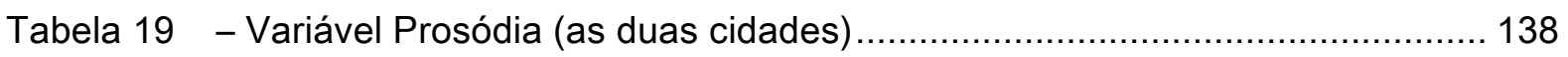

Tabela 20 - Variável Número de Sílabas (as duas cidades) ........................................ 140

Tabela 21 - Variável Frequência de Uso de Palavras (as duas cidades)....................... 142

Tabela 22 - Frequências da variável Escolaridade (as duas cidades) .......................... 144 
Tabela 23 - Frequências da variável Gênero (as duas cidades) .................................. 144

Tabela 24 - Frequências da variável Faixa Etária (as duas cidades)............................ 144

Tabela 25 - Variável Informante (as duas cidades) …............................................. 145

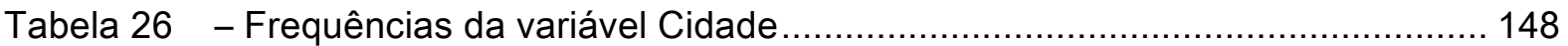

Tabela 27 - Resultados de aplicação de queda de sílaba em Capivari .......................... 152

Tabela 28 - Variável Igualdade de Segmentos apenas da rodada 2 (Capivari).............. 154

Tabela 29 - Variável Cavidade Oral das Consoantes com Distinção do Traço [nasal]

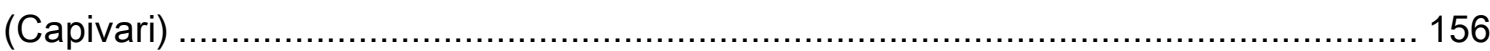

Tabela 30 - Variável Cavidade Oral das Vogais (Capivari) ........................................ 158

Tabela 31 - Variável Estrutura Silábica (Capivari) ........................................................ 160

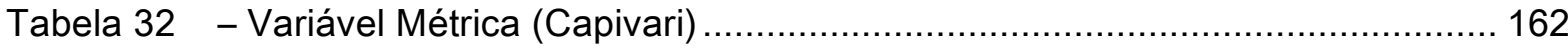

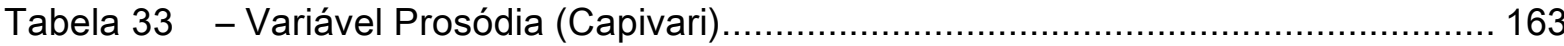

Tabela 34 - Variável Número de Sílabas (Capivari) ...................................................... 165

Tabela 35 - Variável Frequência de Uso de Palavras (Capivari) .................................. 166

Tabela 36 - Frequências da variável Escolaridade (Capivari) ..................................... 167

Tabela 37 - Frequências da variável Gênero (Capivari)............................................ 167

Tabela 38 - Frequências da variável Faixa Etária (Capivari) …................................... 168

Tabela 39 - Resultados de aplicação de queda de sílaba em Campinas ....................... 170

Tabela 40 - Variável Igualdade de Segmentos (Campinas) ...................................... 171

Tabela 41 - Variável Cavidade Oral das Consoantes com Distinção do Traço [nasal] (Campinas)

Tabela 42 - Variável Cavidade Oral das Vogais (Campinas) ....................................... 174

Tabela 43 - Variável Estrutura Silábica (Campinas)................................................... 176

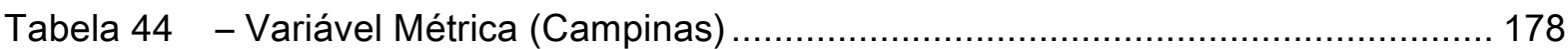

Tabela 45 - Variável Prosódia (Campinas) ................................................................. 179

Tabela 46 - Variável Número de Sílabas na rodada 2 (Campinas) .............................. 181

Tabela 47 - Variável Frequência de Uso de Palavras (Campinas) ................................ 182

Tabela 48 - Frequências da variável Escolaridade (Campinas) ................................... 183

Tabela 49 - Frequências da variável Gênero (Campinas)............................................. 184

Tabela 50 - Frequências da variável Faixa Etária (Campinas) ...................................... 184 
Tabela 51 - Comparação da variável Gênero na rodada Geral, em Capivari e em Campinas

Tabela 52 - Frequências das variáveis externas de Escolaridade e Faixa Etária da rodada

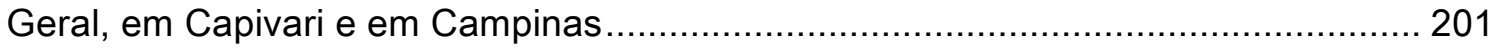

Tabela 53 - Resumo das tendências das fatores em Capivari e Campinas.................... 203

Tabela 54 - Resumo das diferenças, semelhanças e igualdades em Capivari e Campinas 206

Tabela 55 - Relação entre a queda de sílaba e a hierarquia de acento em que primeira palavra é $[\mathrm{x} \cdot]$ ) 


\section{Lista de Gráficos}

Gráfico 1 - Relação entre constituintes na geometria de traços .................................... 19

Gráfico 2 - Geometria de traços (adaptado de Clements \& Hume 1995: 292) .................. 20

Gráfico 3 - Organização interna de traços das consoantes /t/ e /d/.............................. 21

Gráfico 4 - Espectrograma de queda do clítico: posTO DE SAúde > pos(TO DE) saúde

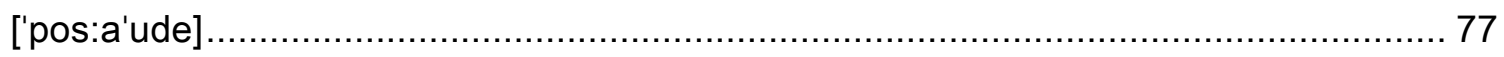

Gráfico 5 - Semelhanças nos pesos relativos da variável Frequência de Uso das Palavras 121

Gráfico 6 - Variável Igualdade de Segmentos (as duas cidades). 126

Gráfico 7 - Variável Cavidade Oral das Consoantes com Distinção do Traço [nasal] (as duas cidades) 129

Gráfico 8 - Variável Cavidade Oral das Vogais (as duas cidades) ............................... 132

Gráfico 9 - Variável Estrutura Silábica (as duas cidades) ........................................... 134

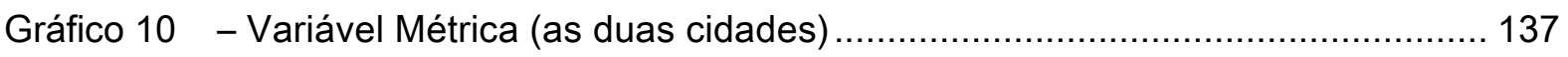

Gráfico 11 - Variável Prosódia (as duas cidades) ..................................................... 140

Gráfico 12 - Variável Número de Sílabas (as duas cidades) ......................................... 141

Gráfico 13 - Variável Frequência de Uso de Palavras (as duas cidades) ....................... 143

Gráfico 14 - Pesos relativos da variável Informante (rodada 1 - as duas cidades)......... 147

Gráfico 15 - Variável Igualdade de Segmentos apenas da rodada 2 (Capivari) ............. 155

Gráfico 16 - Variável Cavidade Oral das Consoantes com Distinção do Traço [nasal]

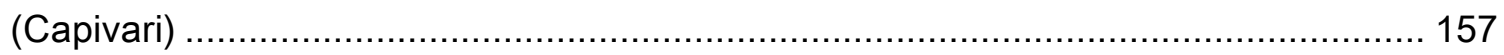

Gráfico 17 - Variável Cavidade Oral das Vogais (Capivari)........................................ 159

Gráfico 18 - Variável Estrutura Silábica (Capivari) ................................................... 161

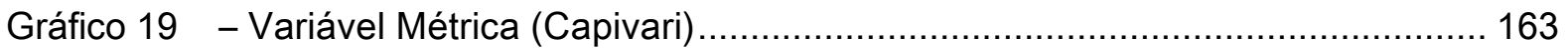

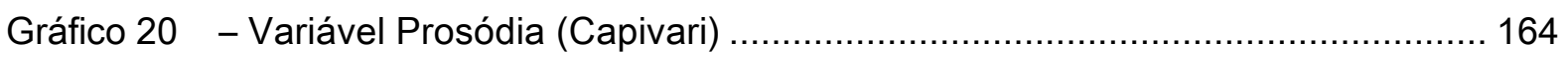

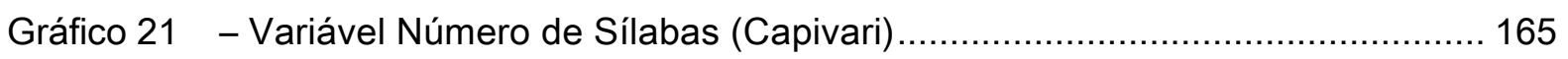

Gráfico 22 - Pesos relativos da variável Informante (Capivari) …................................. 168

Gráfico 23 - Variável Igualdade de Segmentos (Campinas) ....................................... 172 
Gráfico 24 - Variável Cavidade Oral das Consoantes com Distinção do Traço [nasal]

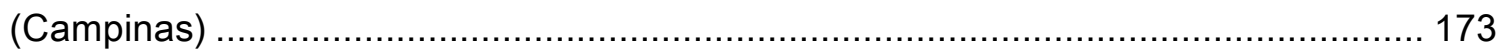

Gráfico 25 - Variável Cavidade Oral das Vogais (Campinas) ...................................... 175

Gráfico 26 - Variável Estrutura Silábica (Campinas) ..................................................... 177

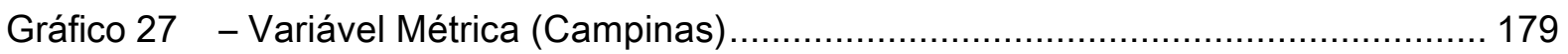

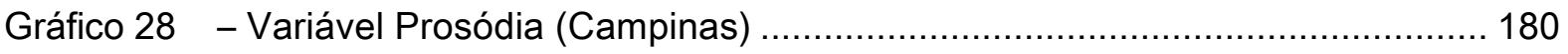

Gráfico 29 - Variável Número de Sílabas na rodada 2 (Campinas) ............................... 181

Gráfico 30 - Variável Frequência de Uso de Palavras (Campinas) ................................. 182

Gráfico 31 - Pesos relativos da variável Informante (Campinas) ................................. 185

Gráfico 32 - Comparação da variável Prosódia na rodada Geral, em Capivari e em Campinas 188

Gráfico 33 - Comparação da variável Cavidade Oral das Consoantes com Distinção do Traço [nasal] na rodada Geral, em Capivari e em Campinas. 190

Gráfico 34 - Comparação da variável Cavidade Oral das Vogais na rodada Geral, em Capivari e em Campinas 192

Gráfico 35 - Comparação da variável Estrutura Silábica na rodada Geral, em Capivari e em Campinas. 194

Gráfico 36 - Comparação da variável Métrica na rodada Geral, em Capivari e em Campinas 196

Gráfico 37 - Comparação da variável Igualdade de Segmentos na rodada Geral, em Capivari e em Campinas 198

Gráfico 38 - Geometria dos nós: raiz, laringal e cavidade oral (adaptado de Clements \& Hume 1995: 292) 221

Gráfico 39 - Aplicação de queda de sílaba: nó de raiz 222

Gráfico 40 - Geometria dos nós: raiz, laringal e cavidade oral (adaptado de Clements \& Hume 1995: 292) 


\section{CAPÍTULO I}

\section{Introdução}

Esta tese (praticamente) teve início a partir de um diálogo entre duas capivarianas, uma senhora e sua neta, em que esta perguntava onde estava seu pai: ${ }^{1}$

$\begin{array}{ll}\text { Criança } & - \text { Vó, cadê meu pai? } \\ \text { Avó } & - \text { Foi na academia. } \\ \text { Criança } & - \text { Quem é Mia? }\end{array}$

No diálogo acima, na academia tem uma forma fonética muito semelhante na produção da avó (cf. (1)) e na percepção da criança (ver (2)):2
(1) produção da avó
$>\quad$ [ne.,ka.de.'mi.a]
(2) percepção da criança
[ne.'ka.de.'mi.a]

As formas fonéticas não são idênticas, já que a sílaba [ka] recebe acento secundário em (1) e acento primário em (2). No entanto, esta diferença não resolve a ambiguidade entre o que a avó produziu e o que a neta entendeu. A diferença entre a forma fonológica da avó (ver (3)) e a forma fonológica da criança (cf. (4)) é dada a seguir:
(3) /na.a.,ka.de.'mi.a/ >
$\mathrm{n}[\mathrm{a}]$ cademia
$>\quad$ [na.,ka.de.'mi.a]
(4) /na.'ka.za.de.'mia/ >
na ca(sa) de Mia
[na.'ka.de.'mi.a]

Um outro exemplo do mesmo fenômeno ocorre na realização a seguir, em que o output fonético em (5) pode ser resultado de dois inputs fonológicos em Capivari; o primeiro, apresentado em (5)a), é comum a diversos outros falares, enquanto que o input (5)b) é

\footnotetext{
${ }^{1}$ No diálogo a seguir, esclareço que não há regra de alçamento em Capivari e o artigo não é usado na frente de nomes próprios.

2 Em todos os exemplos desta tese, as transcrições seguem o IPA (International Phonetic Alphabet) e, como se vê em (1) e (2), os símbolos " ' " e " , " indicam acento primário e secundário, respectivamente.
} 
peculiar à Capivari: ${ }^{3}$

(5) ['vi.a.ka.'de.le]

a) Vi a cadela.

b) Vi a ca(SA) DEla.

A peculiaridade que encontramos em Capivari está apresentada na queda de sílaba em (5)b) ca(sa) dela: se a realização em (5) ['vi.a.ka.'de.le] for ouvida por um campineiro, a única interpretação para ele é (5)a) Vi a cadela, e nunca (5)b)Vi a ca(SA) DEla. Para os capivarianos, é o contexto que vai dizer se o assunto é "uma cachorra" ou "uma casa". Curiosamente, se o tópico da conversa for "uma casa", com uma realização ['ka.'de.le], os capivarianos parecem não notar a ambiguidade com "a fêmea do cão". Note ainda que há diferença no acento da sílaba ka: em Vi a cadela, o [ka] é uma sílaba fraca, ['vi.a.ka.'de.le], enquanto que em $\mathrm{Vi}$ a $c a(S A)$ DEla, o [ka] que restou de casa porta acento primário ['vi.a.'ka.'dع.le]. Mesmo com esta diferença acentual, há ambiguidade.

Foi a partir desta diferença entre uma produção que pode ser ambígua em Capivari e que pode causar estranhamento em Campinas que decidimos por entender melhor a queda de sílaba nas duas cidades.

Assim, o principal objetivo desta tese é analisar as características de queda de sílaba em duas cidades do interior paulista, Capivari e Campinas, observando-se se as variáveis linguísticas e sociais que podem interferir neste processo fonológico atuam de maneira igual ou diferente nas duas cidades, tendo como assunção que a aplicação da queda de sílaba não se dá aleatoriamente em nenhuma das cidades.

Para as interferências linguísticas, os níveis analisados foram o segmental (consoantes e vogais), o suprassegmental (estrutura silábica, métrica, prosódia e número de sílabas) e o lexical (neste caso, a análise diz respeito à frequência de uso de palavras). Com relação às variáveis sociais, examinamos a atuação da escolaridade, do gênero e da faixa etária dos informantes.

$\mathrm{Na}$ próxima subseção, passamos a delimitar o escopo do trabalho, definindo o processo fonológico.

3 O contexto segmental de queda de sílaba está representado em maiúsculas e os parênteses indicam o apagamento de segmento(s). 


\subsection{O que é a queda de sílaba?}

Os estudos sobre a queda de sílaba não são novos. Uma de nossas referências mais constantes é de, por exemplo, 30 anos (cf. Alkmim \& Gomes 1982). De modo geral, a queda de sílaba é definida como um processo fonológico em que a adjacência de duas sílabas que tenham unidades internas iguais ou semelhantes resulta em apagamento de uma delas. Nesta tese, o processo estudado é o de sândi externo, ou seja, a queda de sílaba que ocorre entre fronteiras maiores do que a palavra.

Geralmente, a queda de sílaba é dividida em dois processos fonológicos: a elisão silábica (exemplificado em (7)) e a haplologia (cf. exemplo (6)) - este é o tipo de queda de sílaba mais estudado na literatura (cf. referências apresentadas na seção 3). Em linhas gerais, a diferença entre elisão silábica e haplologia é que, nesta última, as consoantes podem diferir, no máximo, no traço [vozeamento] (cf. exemplo (6)), enquanto que na elisão silábica, há mais diferença do que [vozeamento] - em (7), as consoantes diferem em [nasal], por exemplo, e aplicação é possível (em Capivari, cf. Leal 2006). Os exemplos (6), (7) e (9) são de Leal (2006) e o exemplo (8) é de Alkmim \& Gomes (1982: 49):
(6) /te+da/ na fren(TE) DA popular
['frẽ.da] popular
(ALES)
(7) /dos+nuN/ senta(DOS) NUM canto
sen['ta.nũ] canto
(ALES)
(8) /go+de/ *pin(GO) DE leite ${ }^{5}>$ ping(o) de leite *pin[dzi] leite
(teste)
(9) /va+bo/ *viú(VA) BOnita > viúV(A) BOnita *viú[bu]nita
(teste)

No exemplo (6), o contexto consonantal /te+da/ é formado por duas consoantes coronais [-contínuo], na terminologia da geometria de traços (cf. Clements \& Hume 1995 e subseção 2.2.1), com uma única diferença entre as consoantes, o [vozeamento]: /t/ é [-vozeado] e /d/ é [+vozeado]). O contexto consonantal /d+n/ em (7) é composto também de duas coronais [-contínuo], mas a primeira é oral e a segunda é uma nasal. ${ }^{6}$ Pode haver aplicação de queda de sílaba no exemplo (6), de acordo com Alkmim \& Gomes (1982), Battisti (2004), Tenani (2002), Pavezi (2006a) e Leal (2006); e foram atestados casos de

\footnotetext{
${ }^{4} \mathrm{O}$ informante que proferiu a sentença está marcado pelas letras entre parênteses; aqueles em que estão marcados (teste) são exemplos do teste de gramaticalidade de Leal (2006).

5 Usamos o sinal de asterisco para indicar que a sentença é agramatical.

6 Observe que $/ \mathrm{n} /$, apesar de ser [+contínuo] na cavidade nasal, é [-contínuo] na cavidade oral (cf. 2.2.1 e Clements \& Hume 1995).
} 
queda de sílaba em contextos como (7) no dialeto de Capivari, segundo Leal (2006). Por outro lado, há bloqueio da queda de sílaba nos exemplos (8) e (9): no primeiro caso, o contexto /go+de/ são duas consoantes [-contínuo] com pontos de C diferentes, [dorsal + coronal]; no segundo caso, as consoantes de /va+bo/ são duas [labial], e a diferença do contexto está no valor para contínuo: a primeira consoante /v/ [+contínuo] e a segunda /b/ [contínuo]) torna a sentença agramatical, mesmo tendo um valor igual de ponto de C.

Estes exemplos (6)-(9) ilustram que a queda de sílaba depende do contexto consonantal para ocorrer: os nós das cavidades orais das consoantes devem ser iguais (cf. Leal 2006), sendo que há bloqueio se as consoantes forem diferentes em ponto de C (ver (8)) ou em [contínuo] (cf. (9)).

Como vimos nos exemplos, há aplicações de queda de sílaba que não são aceitas em Campinas, mas que são usuais em Capivari, embora as cidades tenham uma mesma herança dialetal (cf. subseção 1.2 a seguir). Desta forma, apresento os panoramas sociais e os dialetos de Capivari e de Campinas na subseção a seguir.

\subsection{As cidades: os panoramas sociais e os dialetos}

A escolha de se estudar Capivari foi feita a partir dos resultados obtidos em minha dissertação de mestrado (Leal 2006): neste trabalho, verificou-se que o contexto segmental de queda de sílaba é mais abrangente (em termos de traços fonológicos) do que aqueles reportados na literatura (cf. Capítulo III e referências ali citadas).

Ao longo da feitura da dissertação, pudemos notar também que contextos segmentais que eram gramaticais em Capivari (tanto nos testes quanto nos dados das entrevistas) eram agramaticais para falantes de cidades próximas. Escolhemos então eleger Campinas, cidade a 54 quilômetros, e cujos informantes apresentam o fenômeno nos moldes em que ele é descrito pela literatura para comparação. Assim, dada as diferenças de aplicação de queda de sílaba, um trabalho interessante seria comparar as duas cidades, quantificando dados, a fim de verificar se há, de fato, diferenças na aplicação de queda de sílaba entre Capivari e Campinas.

Outros fatores interessantes se colocaram: estas duas cidades têm uma mesma herança dialetal (cf. subseção 1.2.1), mas seguiram caminhos diferentes de desenvolvimentos sociais e dos dialetos (cf. subseções 1.2.1 e 1.2.2). Nacionalmente, Campinas é uma região metropolitana $(R M)$, uma região administrativa $(R A)$ e uma região 
de governo $(R G)$, enquanto que Capivari pertence à $R M$ e à $R A$ de Campinas e à $R G$ Piracicaba. $^{7}$

Nas subseções a seguir, examinamos brevemente a história da formação das duas cidades e seus panoramas socioeconômico atuais (cf. 1.2.1); em seguida, descrevemos como a definição do contexto segmental de queda de sílaba pode depender do dialeto estudado, nosso ponto de partida para a comparação entre os dialetos de Campinas e Capivari (ver 1.2.2).

\subsubsection{Formação das cidades e panoramas sociais}

$\mathrm{Na}$ época da colonização, houve diversos momentos de picos de vindas de portugueses ao Brasil, como o da "corrida do ouro", no final do século XVII (Mattos e Silva 2004: 74-5). A exploração do ouro foi uma das principais razões para a formação das cidades de Campinas e Capivari: ${ }^{8}$ exploradores em busca de riqueza e bandeirantes enviados pela corte saíam da região de São Paulo, entrando pelas matas e rios, em direção ao estado do Mato Grosso (região em que havia jazidas de ouro), formando-se acampamentos por essas passagens. Estes acampamentos acabavam por se tornar vilarejos nas áreas em que hoje estão Campinas e Capivari.

No século XIX, depois do estabelecimento das cidades propriamente ditas (Campinas em 1774 e Capivari em 1832), a agricultura passa a ser a principal atividade econômica, com base principalmente nas lavouras de cana de açúcar e café. Estas sociedades eram constituídas de donos de engenho e de migrantes (provindos de cidades vizinhas) e imigrantes, que supriam a mão de obra barata.

Já nas décadas de 1950 e 1960, o movimento de migração populacional das zonas rurais para as urbanas faz com que Campinas se destaque como o grande pólo urbano no interior de São Paulo, enquanto que a urbanização de Capivari pode ser comparada à dos bairros de Campinas na mesma época. Numa entrevista que faz parte do corpus deste

\footnotetext{
7 RM é a reunião de um centro populacional (a cidade de Campinas neste caso) e suas cidades satélites, que tenham alto grau de integração (econômica, política ou cultural). RA e RG são subdivisões que estão abaixo dos estados, aglomerados de cidades de acordo com similaridades econômicas e sociais. RMs estão previstas na Constituição Federal: cada estado brasileiro pode "instituir regiões metropolitanas, aglomerações urbanas e microrregiões, constituídas por agrupamentos de Municípios limítrofes, para integrar a organização, o planejamento e a execução de funções públicas de interesse comum." (cf. Artigo 25 parágrafo $3^{\circ}$ da Constituição Federal). As RGs estão subordinadas às RAs e estas às RMs.

8 Cf. websites do IBGE e das prefeituras dos municípios de Campinas e de Capivari (cf. referências bibliográficas).
} 
trabalho, a informante $m$ (que tem ensino fundamental incompleto, de 54 anos) relata que o aspecto campineiro rural na década de 1960 ainda existia nos bairros: as ruas eram de terra e de difícil acesso, como era o centro da cidade de Capivari nessa mesma década de 1960 (panorama que ainda persiste nos dias de hoje em alguns bairros do subúrbio desta cidade).

A partir dos anos 80, o quadro socioeconômico de Campinas se torna semelhante ao atual: pessoas do nordeste e do sul do país passam a viver nesta cidade, em busca de trabalho; nos dias de hoje, a cidade de Campinas é um dos grandes centros urbanos do Brasil. Quanto à Capivari, uma das bases econômicas ainda é usinas de cana de açúcar, embora a cidade possua metalúrgicas, indústrias de bebida e de tecelagem, e diversos estabelecimentos comerciais.

Com relação ao quadro populacional (cf. dados do IBGE 2010), Campinas tem uma área de $795 \mathrm{Km}^{2}$, com uma população de um pouco mais de um milhão de habitantes (1.080.999), enquanto que a área territorial de Capivari é de $323 \mathrm{Km}^{2}$, contando com 48.573 habitantes - portanto, a área de Campinas é quase 2,5 vezes maior do que a de Capivari; aquela cidade possui 22,3 vezes mais habitantes do que esta. Outra informação a respeito das duas cidades é o Índice de Desenvolvimento Humano - Municipal (IDH-M), ${ }^{9}$ que pode variar de 0 (nenhum desenvolvimento humano) a 1 (desenvolvimento humano total): IDH-M (geral) de CAMPINAS é 0,852, enquanto que o de Capivari é 0,803; com relação ao IDHMeducação, os campineiros têm um desenvolvimento de 0,925 e os capivarianos, 0,86 . Isto significa que as duas cidades têm um alto desenvolvimento humano - apesar da diferença de Campinas ser uma cidade de grande porte, e Capivari uma cidade pequena.

\footnotetext{
9 O Índice de Desenvolvimento Humano foi feito para medir o desenvolvimento humano nos países. Depois, foram feitas modificações para se trabalhar com cidades (Índice de Desenvolvimento Humano - Municípios IDH-M). A base para o índice é 3 indicadores: educação (taxas de alfabetização e de matrícula em todos os níveis de ensino da cidade), longevidade (expectativa de vida ao nascer na cidade) e renda (PIB da cidade, em dólar PPC - paridade do poder de compra). Um índice na faixa de 0 a 0,499 pode ser considerado baixo; de 0,500 a 0,799: desenvolvimento humano considerado médio; e maior que 0,800: desenvolvimento humano alto (cf. "Entenda o cálculo do IDH Municipal (IDH-M)": www.pnud.org.br/atlas/PR/Calculo_IDH.doc).
} 


\subsubsection{Os dialetos capivariano e campineiro}

Primeiramente, é necessário discutir o que entendemos por dialeto. Neste trabalho, usamos este termo lato sensu, como sinônimo de "variedade de uma língua própria de uma região"10 ou cidade, mas esclarecemos que há muito mais complexidade por trás desta simples definição que estamos empregando: Camacho (1988) ressalta que não é apenas a limitação (geográfica) da cidade que dita as diferenças entre os falares. Em outras palavras, um dialeto pode não estar circunscrito apenas a uma distinção diatópica, mas pode estar relacionado também à comunidade de fala em que um indivíduo está inserido, às suas práticas sociais, e outras variáveis externas à língua. Uma vez que o foco desta tese é (principalmente) o linguístico (buscar uma regra de queda de sílaba), o termo "dialeto" foi usado de forma ampla, numa tentativa de delimitar "dialeto de Capivari", "dialeto de Campinas"; "dialeto de São José do Rio Preto", "dialeto de São Paulo", e outros - ou seja, discutir o que é um dialeto foge do escopo desta tese.

Quanto à forma de falar nesses dois lugares, Amaral (1920) e Garcia (2009a, 2009b) descrevem particularidades do falar capivariano, e Leite $(2004,2005,2011)$ trata de Campinas. Amaral e Garcia classificam o modo de falar capivariano como pertencente ao dialeto caipira. Amaral exemplifica a troca do fonema /// por [c] (como em $c[c] a r o$ em lugar de claro), um dos muitos "vícios de pronúncia" (cf. Amaral 1920) atribuídos ao falar caipira. Com relação ao dialeto campineiro, a maioria dos trabalhos são voltados ao $/ r /$ retroflexo (Leite 2004, 2005, 2011). Especificamente em sua tese, Leite (2004) faz uma análise sociolinguística sobre o /r/ retroflexo de Campinas, relacionando-o a atitudes linguísticas de estudantes de São José do Rio Preto (isto é, outra cidade do interior paulista). A autora trabalhou com 8 informantes de São José do Rio Preto que estudam em Campinas e verificou que há um prestígio do dialeto campineiro por parte destes estudantes riopretenses (Campinas é uma grande cidade, com poder econômico, tem representatividade se comparada às outras cidades do interior). $\mathrm{Na}$ visão dos estudantes, o campineiro tem uma fala socialmente menos marcada (cf. Leite 2004: 132) do que as outras cidades do interior paulista. Por fim, a autora conclui que há um mascaramento do retroflexo pelos falantes da sua pesquisa, pois entendem que o dialeto de Campinas é uma fala

\footnotetext{
10 Cf. definição em Dicionário Priberam da Língua Portuguesa [online].
} 
intermediária (é uma cidade do interior, mas o dialeto tem mais prestígio do que o caipira cf. Leite 2004: 97-113).

Especificamente para a queda de sílaba, apresentamos diversos trabalhos sobre haplologia, de variados dialetos: Alkmim \& Gomes (1982) não afirmam qual é o dialeto estudado, e definem-no como "sotaque brasileiro" (p. 44); Tenani $(2002,2003)$ estudam o dialeto de São José do Rio Preto; Battisti (2004) analisa o de Porto Alegre; Bisol (2000) também não define qual a variedade estudada, chamando-a de "dialetos populares" do português brasileiro (p. 406); Pavezi (2006a) analisa os dialetos de São Paulo (corpus NURC-SP) e de São José do Rio Preto (corpus IBORUNA-SJRP); finalmente, Leal (2006, 2007) estudam o falar da cidade de Capivari. Até onde sabemos, não há nenhum estudo sobre queda de sílaba com informantes de Campinas.

Notamos que a queda de sílaba é descrita de modo diferente (cf. também Capítulo III) nestes trabalhos citados: com relação ao contexto consonantal, por exemplo, Alkmim \& Gomes (1982) afirmam que a haplologia só pode ocorrer com as consoantes /t/ e /d/; em Porto Alegre, Battisti (2004) estuda contextos segmentais somente com /t/ e /d/, sem analisar outras consoantes, já que o objetivo da autora é verificar a natureza da haplologia; da mesma forma, Tenani (2002) não analisa contextos diferentes de $/ \mathrm{t} / \mathrm{e} / \mathrm{d} /,{ }^{11}$ já que o foco do estudo é verificar a relação entre a prosódia e a haplologia; Bisol (2000) também não analisa o contexto segmental (seu objetivo é verificar a relação entre haplologia e o ritmo), mas apresenta um exemplo de aplicação do processo com $/ \mathrm{k}+\mathrm{k} /$. Dois trabalhos focam o contexto segmental: em Pavezi (2006) e Leal (2006), a haplologia pode ocorrer com contextos diferentes de /t/ e /d/ (cf. também capítulo 3 desta tese). Em outras palavras, notamos que, em dialetos diferentes, a queda de sílaba parece se dar também de modo diferente.

No exemplo (5)b) da seção 1 , vimos que há uma diferença na aceitação de Vi a $c a(S A) D E l a:$ para capivarianos, a queda de sílaba é possível, enquanto que a aplicação do processo causa estranhamento aos campineiros. É esta a oposição entre Capivari e Campinas com que trabalhamos: as cidades podem ter regras de queda de sílaba diferentes. Tendo em vista esta hipótese, observe a seguir a afirmação de Guy \& Zilles

11 Tenani (2002: 135-6) explica: "Para argumentar que a ocorrência da haplologia é sensível à estrutura prosódica, buscamos inicialmente identificar os contextos segmentais que favorecem o processo, tomando como ponto de partida (...) A descrição do contexto segmental feita por Alkimim \& Gomes (1982)." 
(2007: 221):

Sempre que o pesquisador pensar que há possibilidade de os subgrupos ou indivíduos incluídos na análise terem gramáticas diferentes, pode rodá-los separadamente, permitindo assim que cada um tenha diferentes valores dos fatores. Feito isso, o pesquisador pode comparar os resultados das rodadas separadas: se mostrarem diferenças importantes, deve manter os grupos separados. Se mostrarem resultados basicamente iguais eles (os subgrupos ou indivíduos) podem ser combinados numa rodada unificada.

Com base na citação acima, analisamos primeiramente a queda de sílaba nas duas cidades computadas em conjunto (cf. capítulo V); em seguida, com o objetivo de verificar se há duas gramáticas diferentes em Capivari e Campinas, as cidades foram analisadas em separado (ver capítulos VI e VII, respectivamente).

Dito de forma simples, a questão que norteia esta tese é:

Há diferenças na regra de queda de sílaba em Capivari e Campinas?

\subsection{O quadro teórico e questões a serem respondidas}

Como foi dito na seção 1, o principal objetivo desta tese é verificar se há uma regra de queda de sílaba em Capivari e outra em Campinas, ou se as duas cidades têm características iguais para o processo. Dessa forma, não partimos de uma regra (geral) a priori ${ }^{12}$ e empregamos a metodologia laboviana de quantificação dos dados, o que significa que, num dado contexto segmental, as possibilidades de aplicação ou não aplicação de queda de sílaba são contadas e, a partir destas quantificações, podemos verificar quais interferências linguísticas e sociais atuam no processo - de modo a favorecê-lo ou inibi-lo. Assim, algumas questões linguísticas a serem discutidas são:

- Há uma consoante que favorece/inibe o processo?

- Há uma vogal que favorece/inibe o processo?

- Duas sílabas iguais favorecem mais o processo do que sílabas diferentes? Sílabas diferentes inibem o processo?

- Sílabas com estrutura CV favorecem/inibem o processo?

- Que tipo de estrutura métrica favorece/inibe o processo?

\footnotetext{
12 A única restrição que adotamos é que a sílaba sujeita à queda deve ser fraca, cf. exemplo (10) a seguir (ver também discussão em 2.2.3).
} 
- Que tipo de estrutura prosódica favorece/inibe o processo?

- O tamanho fonológico, isto é, o número de sílabas da palavra, interfere de que forma no processo?

- A frequência de uso de palavras (ou seja, ser uma palavra muito frequente, frequente e rara) interfere no processo?

Além das características linguísticas, também apontamos questões relacionadas a variáveis sociais, como:

- Qual cidade favorece/inibe a queda de sílaba: Capivari ou Campinas? Há regras de queda de sílaba distintas nas duas cidades ou a implementação do processo é igual/semelhante?

- Características sociais, como escolaridade, gênero e faixa etária, interferem no processo de que modo?

Há ainda a possibilidade de encontrarmos no corpus dados categóricos, ou seja, bloqueios de queda de sílaba, que podem ser verificados em ocorrências com knockouts. Assim, algumas questões a serem verificadas são:

- Há alguma consoante, vogal ou estrutura de sílaba que bloqueie o processo?

- Há uma estrutura métrica que bloqueie o processo?

- Há uma estrutura prosódica que bloqueie o processo?

- O tamanho da palavra envolvida no contexto pode bloquear processo?

- A frequência com que uma palavra é utilizada pode bloquear o processo?

Para exemplificar, temos que o processo nunca ocorre se a sílaba sujeita ao apagamento for forte (cf. Alkmim \& Gomes 1982, Bisol 2000, Mercado 2001, Tenani 2002, 2003, Battisti 2004, Pavezi 2006a e Leal 2006), como no exemplo a seguir, de Tenani (2002: 141):

(10) *o di(므) Dltou regras à polícia

A primeira sílaba do contexto segmental /di + di/ é forte em (10), o que ocasiona o 
bloqueio da queda de sílaba. Em outras palavras, na estrutura métrica, há bloqueio de queda de sílaba se a primeira sílaba for forte.

Uma vez que o processo fonológico é silábico (cai a sílaba), a base teórica utilizada foi a teoria da sílaba de Selkirk (1982); como é também processo segmental (desencadeado pela igualdade/semelhança entre as consoantes), utilizamos Clements \& Hume (1995); finalmente, já que pode ser afetado pela prosódia e pela métrica, usamos Nespor \& Vogel (1986) e Selkirk (1984), respectivamente.

\subsection{Organização da tese}

No Capítulo II, apresentamos o quadro teórico utilizado. Em seguida, no Capítulo III, apresentamos a definição do processo de queda de sílaba. No Capítulo IV, apresento a base metodológica, incluindo o envelope de variação linguístico e social (cf. subseção 4.1.4), com as variáveis internas e externas investigadas como atuantes na queda de sílaba. Os dados foram computados em três grandes conjuntos de rodadas: ${ }^{13}$ Geral (com dados das duas cidades), Capivari e Campinas. Primeiramente, todas as ocorrências encontradas no corpus foram rodadas, unindo os tokens tanto da cidade de Capivari quanto de Campinas, e os resultados da análise geral estão reportados no Capítulo V. Nos Capítulos VI e VII, apresento os resultados encontrados para Capivari e Campinas, respectivamente. No Capítulo VIII, há uma comparação entre as duas cidades, em que foram observadas as igualdades, semelhanças e diferenças entre Capivari e Campinas. A partir dos resultados encontrados, apresento algumas questões linguísticas relacionadas à queda de sílaba, no Capítulo IX. Por fim, no Capítulo X, apresento uma conclusão dos resultados encontrados, discutindo o que pôde ser constatado e também as pistas encontradas nesta tese, que podem contribuir para outros estudos a serem feitos.

\footnotetext{
13 Neste trabalho, utilizamos o programa GoldVarb (cf. Sankoff, Tagliamonte \& Smith 2005) para os cálculos estatísticos feitos nos dados. O termo "rodada" é usado para indicar o produto final deste programa (cf. Capítulo IV, em que explicitamos o funcionamento do programa).
} 


\section{CAPÍTULO II}

\section{O quadro teórico}

Antes de apresentar o processo fonológico (cf. seção 3 a seguir), julgamos necessário tratar do quadro teórico que está na base deste estudo.

Os dados do corpus tiveram um tratamento estatístico, seguindo-se a metodologia laboviana, o que implica no estudo da variação, uma interface entre a estrutura linguística e seus aspectos sociais (ou, nos termos sociolinguísticos variacionistas, as variáveis linguísticas e sociais). Assim, apresento na subseção 2.1 como relacionamos a teoria gerativista e o modelo laboviano no presente estudo; e na subseção 2.2, estão as teorias fonológicas utilizadas para análise do corpus.

\subsection{Os modelos variacionista e gerativista: pontos de diálogo ${ }^{14}$}

A questão de unir teoria fonológica e variação é uma discussão que integra diversos trabalhos (Tarallo 1983, 1991; Borges Neto \& Müller 1987; e Pagotto 2004). Utilizar num trabalho estas duas abordagens sobre a linguagem, o gerativismo e a sociolinguística variacionista, pode ser interpretado como contraditório: para o gerativismo, a língua é homogênea, enquanto que a sociolinguística variacionista parte exatamente da heterogeneidade; a gerativa tem uma abordagem mentalista, enquanto que a linha variacionista é crucialmente social (Honeybone 2011).

De acordo com a teoria gerativa, as línguas são estruturadas por princípios e parâmetros (cf. Chomsky 1965). Os princípios chomskyanos são universais, no sentido de que todas as línguas têm as mesmas propriedades capturadas por eles e não há línguas nas quais eles não se apliquem. Os parâmetros por sua vez, são princípios com valores a serem escolhidos. Isto é, dentro de um conjunto de valores possíveis para um parâmetro, as línguas podem variar exatamente por marcações paramétricas diferentes. Mais importante, uma vez marcados os valores dos parâmetros numa determinada língua, não

\footnotetext{
${ }^{14}$ Agradeço os comentários do Prof Dr Ronald Beline, que me levaram a melhorar a discussão desta seção.
} 
há possibilidade de mudança. Com relação ao acento, por exemplo, temos (adaptado de Massini-Cagliari 1995):

1. Princípio: toda palavra é acentuada.

2. Parâmetro de posição do núcleo do pé no português brasileiro: o acento à esquerda ( $v s$. direita) no último pé na palavra fonológica.

Assim, o princípio de que toda a palavra porta acento não muda nas línguas: não há línguas que apresentem palavras sem algum tipo de proeminência (quer acentual (stress), quer tonal (tone)). No que respeita à posição da proeminência, uma vez que a língua faz uma seleção, não há possibilidade de mudança (a estrutura seria agramatical em uma língua com um valor diferente). Por exemplo, o valor do parâmetro (2) gera as seguintes formas acentuadas: menino [me.'ni.nu] e casa ['ka.za]. Não existe, no português, a possibilidade de produção destas palavras como *['me.ni.nu] ou *[me.ni.'nu] e *[ka.'za]. Os erros acentuais por falantes nativos sempre vão dizer respeito a palavras que são exceção à aplicação do parâmetro (por exemplo, saci [sa.'si]). Assim, podemos dizer que a variação está na estrutura possível (na GU - Gramática Universal), que permite que haja mais de um valor para um parâmetro, e esta variação desaparece nas línguas, dado que as línguas fazem a seleção de um valor para o parâmetro.

No entanto, mesmo no gerativismo, existe alguma variação, ao menos ao se discutir fonologia. Isto por dois motivos: primeiro porque, diferentemente da sintaxe, assume-se que na fonologia haja também regras (por exemplo, elisão, degeminação, ditongação), nem todas redutíveis a combinações paramétricas, como foi o acento (cf. em Bisol 1992 a explicação do acento no português brasileiro via regra, e em Massini-Cagliari (1995), na forma de valores paramétricos).

O problema que deve ser resolvido para a pesquisa desta tese está no seguinte aspecto: as teorias fonológicas aqui empregadas são gerativistas (que buscam homogeneidade nas línguas), e a metodologia tem base na variação linguística (na variação regulada). Exemplificando a oposição teórica com o processo estudado, temos: 
(11) Tô com saudaDE DE Los Angeles - sem aplicação de queda

(12) Tô com sauda(DE) DE Los Angeles - com aplicação de queda

Tomando-se por base o gerativismo, em que a língua é homogênea, temos que um mesmo falante pode produzir (11) ou (12) arbitrariamente, uma vez que os ambientes internos nas duas realizações são os mesmos: contexto segmental, acento, prosódia (e outras variáveis linguísticas); no gerativismo, o falante produzir as formas (11) ou (12) é devido ao acaso - à variação livre. Na sociolinguística variacionista, a diferença entre (11) e (12) é o que move os pressupostos labovianos: todas as ocorrências em que houve e não houve aplicação de queda são quantificados, bem como todas as possíveis variáveis (sejam linguísticas, sejam sociais) que podem interferir na aplicação do processo. Em seguida, todas as aplicações versus não aplicações são relacionadas às variáveis (linguísticas e sociais), de onde se conclui quais favorecem, inibem ou são neutros à queda de sílaba. $\mathrm{Na}$ sociolinguística, produzir (11) ou (12) não é aleatório, mas estatisticamente orientado. Nos termos sociolinguísticos, o processo fonológico aqui em estudo é uma regra variável.

Além da questão das regras, na fonologia também assume-se que haja princípios violáveis, como o Princípio de Contorno Obrigatório (OCP), de Leben (1973), ou o Princípio de Alternância Rítmica (PAR), de Selkirk (1984) (cf. também subseção 2.2.3). A autora formula provisoriamente o PAR (p. 12) da seguinte forma: entre duas batidas fortes sucessivas deve $(\mathrm{m})$ intervir pelo menos uma e no máximo duas batida(s) fraca(s). Para garantir a 'obediência' a este princípio, diversas regras podem ser aplicadas (retração acentual, apagamento de sílaba, inserção de batida silenciosa). Observe as grades a seguir, em que os acentos relevantes estão sublinhados (exemplos de Santos 2002: 71):

(13) o josé maria cantou hoje

\begin{tabular}{|c|c|c|c|}
\hline can & $\underline{\text { tou }}$ & $\underline{\text { ho }}$ & je \\
\hline$\cdot$ & $\mathrm{x}$ & $\mathrm{x}$ & $\bullet$ \\
\hline
\end{tabular}

(14) o josé maria cantou hoje

\begin{tabular}{|c|c|c|c|}
\hline can & tou & ho & je \\
\hline $\mathrm{x}$ & $\bullet$ & $\mathrm{x}$ & $\bullet$ \\
\hline
\end{tabular}


De acordo com Abousalh (1997), uma das resoluções para choques acentuais como exemplificado em (13) é a retração de acento apresentada em (14), e esta última é a sequência rítmica que obedece ao PAR. No entanto, chamo a atenção para o fato de que ambas as sentenças são gramaticais, isto é, uma produção como (13) é gramatical, mesmo violando o PAR. Disso podemos concluir que princípios como o PAR (cf. 2.1) não são da mesma natureza do que os princípios sintáticos ou aquele em (1) - são mais tendências a serem buscadas nas línguas.

Desta forma, encontramos 2 casos de variação na fonologia: regras opcionais e princípios/tendências - ambos podendo ou não ser aplicados. Mesmo nestes casos, o que vemos na teoria gerativa atual é uma busca por descobrir a estrutura da língua, a forma como uma língua é organizada, estruturada enquanto sistema.

No caso da sociolinguística variacionista, seu objetivo é exatamente mostrar como a língua não é homogênea, e como há diferenças neste sistema. Estas diferenças podem ser resultado do próprio sistema (diferenças linguísticas) ou de variáveis externas que afetam a produção. O importante aqui não é que pessoas diferentes falam de modo diferente (por exemplo, capivarianos dizem porta ['por.te] enquanto que cariocas dizem ['poh.te], pois isto poderia ser interpretado como dois sistemas (dialetos?) diferentes), mas o fato de que uma mesma pessoa pode produzir a mesma sequência de forma diferente: um mesmo capivariano pode dizer tanto cantou hoje [kẽ.'tow.'o.3i] quanto cantou hoje ['kẽ.tow.'o.zi].

O modo encontrado pela sociolinguística variacionista (cf. Labov 1972, 1994, 2001) para buscar a lógica dentro das línguas é quantificar dados do vernáculo, analisando-os com ferramentas estatísticas e interpretando-os de modo a relacionar quais variáveis (linguísticas e sociais) podem estar agindo num processo fonológico. Além disso, a linha variacionista opera na interface entre o linguístico e o social da língua, em que a base está na heterogeneidade ordenada (Weinreich, Labov, \& Herzog 1968), ou seja, na premissa de que há variações e que são reguladas, e não dadas ao acaso. É pela probabilidade que se pode observar a atuação de variáveis linguísticas e sociais na variação entre cantou hoje [kẽ.'tow.'o.3i] e cantou hoje ['kẽ.tow.'o.zi], por exemplo. 
Dito de forma resumida, o gerativismo busca uma lógica linguística dentro do próprio sistema, com base em princípios e parâmetros imutáveis, sem computar o externo à linguagem, enquanto que a sociolinguística variacionista vê a língua como um sistema dual, e opera na interface entre as variáveis linguísticas e sociais, com base na quantificação destas interferências internas e externas à língua.

Há, no entanto, a questão de como unir a Teoria Fonológica Gerativa e a Sociolinguística Variacionista. Segundo Guy \& Bisol (1991: 135):

(...) estudos quantitativos da língua têm um papel central na avaliação e no desenvolvimento da teoria fonológica. (...) acreditamos que essa espécie de interação entre teoria e dado, entre construção de modelos e observação, representa a mais produtiva linha de futuras pesquisas linguísticas. (grifos meus)

Assim, os estudos quantitativos serviriam para avaliar as propostas descritivas/explicativas das teorias fonológicas, contribuindo para o desenvolvimento das mesmas. Pagotto (2004: 195), por outro lado, afirma que:

"(...) não operamos com o pressuposto de que a sociolinguística seja (...) somente um dispositivo heurístico para a testagem de hipóteses oriundas da Linguística (...)." (grifo meu)

Neste trabalho, os pontos de diálogo entre os dois modelos serão interpretados com relação à tendência da queda de sílaba e sua produtividade. ${ }^{15}$ Como dito em 1.2.2, nosso objetivo é descobrir se a regra de queda de sílaba é a mesma em Capivari e Campinas. Para chegar a esta resposta, observaremos a tendência e a produtividade (expressos via peso relativo da sociolinguística variacionista) dos diferentes contextos possíveis das regras (definidos pela fonologia gerativa). Os contextos são as variáveis (linguísticas e sociais) analisadas neste trabalho. Uma variável que tenha uma mesma tendência (favorecimento, neutralidade ou desfavorecimento) e uma mesma produtividade (pesos relativos muito

\footnotetext{
15 Agradeço a Emílio Pagotto por me chamar a atenção para a discussão entre produtividade e expansão de contexto de regra, que me levaram ao recorte que farei para a interpretação dos resultados encontrados.
} 
próximos) é interpretada como uma mesma propriedade da regra em Capivari e em Campinas. Se os resultados de uma variável tiverem tendências iguais mas os pesos relativos forem diferentes, a interpretação é que há uma mesma regra, com produtividade diferente nas duas cidades. Finalmente, tendências diferentes (e, consequentemente, produtividade e pesos relativos diferentes) indicam que há duas regras diferentes: uma para Capivari, outra para Campinas.

Assim, esta tese tem base na teoria fonológica gerativista em que, de modo geral, a sistematização da linguagem é feita pela forma ou estrutura, mas integramos também o modelo de quantificação de dados da sociolinguística variacionista, a fim de examinar quais variáveis (propriedades) interferem na aplicação da queda de sílaba nas duas cidades.

\subsection{Teorias fonológicas}

Nesta seção, apresento as teorias utilizadas para a análise do corpus, compreendendo os níveis fonológicos da estrutura interna do segmento (ver geometria de traços em 2.2.1) e da sílaba (cf. subseção 2.2.2), a métrica (subseção 2.2.3) e os constituintes prosódicos (ver 2.2.4).

\subsubsection{Geometria de traços: a estrutura interna dos segmentos}

A fim de justificar por que o uso da Geometria de Traços é importante na análise do corpus, observe, primeiramente, os contextos consonantais dos exemplos a seguir, definidos de acordo com a fonologia tradicional: ${ }^{16}$

$\begin{array}{llll}\text { (15) tape(TE) DA porta } & / \mathrm{t} / \text { [plosiva alveolar] } & + & / \mathrm{d} / \text { [plosiva alveolar] } \\ \text { (16) lógi(CO) QUE não } & / \mathrm{k} / \text { [plosiva velar] } & + & / \mathrm{k} / \text { [plosiva velar] } \\ \text { (17) quei(JO) saboroso } & / 3 / \text { [fricativa pós-alveolar] } & + & / \mathrm{s} / \text { [rricativa alveolar] } \\ \text { (18) }{ }^{*} \text { esco(VA) SEparada } & / \mathrm{V} / \text { [fricativa labio-dental] } & + & / \mathrm{s} / \text { [rricativa alveolar] }\end{array}$

Numa análise dos segmentos nos moldes estruturalistas tradicionais, podemos

16 Os exemplos (15)-(18) são dos testes de gramaticalidade de Leal (2006). 
observar que em (15) há duas plosivas alveolares; em (16), o contexto é formado por duas plosivas velares; em (17), o ambiente para a queda de sílaba é composto de duas fricativas, a primeira é pós-alveolar e a segunda é alveolar; finalmente, em (18), há também duas fricativas, com pontos de consoantes diferentes - [labio-dental] e [alveolar], respectivamente. Se a queda de sílaba ocorre com segmentos iguais, a descrição tradicional dos segmentos dá conta da possibilidade de aplicação em (15) (são duas plosivas alveolares) e em (16) (duas plosivas velares); explica também porque há bloqueio em (18), pois as consoantes têm o mesmo modo de articulação (duas fricativas), mas, dado que o ponto é diferente (labio-dental seguida + alveolar), a queda de sílaba não pode ser aplicada. No entanto, como explicar que em (17) o processo seja possível, se os pontos de articulação de /3/ e /s/ são diferentes ([pós-alveolar] e [alveolar], respectivamente)? Esta dificuldade em descrever os dados pela fonologia tradicional pode ser resolvida pela análise via geometria de traços.

Uma das diferenças entre as abordagens tradicional e a geometria de traços está no ponto de vista de como os sons são articulados: na primeira, os segmentos são definidos de acordo com seus articuladores passivos: num /t/, por exemplo, a língua bate nos alvéolos localizados na parte frontal da cavidade oral e esta é a descrição deste som (uma consoante alveolar). $\mathrm{Na}$ geometria, os traços são concebidos conforme os articuladores ativos: na produção de um /t/, por exemplo, a ponta da língua que atinge os alvéolos é o que descreve esse som (é chamado de consoante coronal - corona, ponta da língua - cf. Chomsky \& Halle 1968; Jakobson, Fant \& Halle 1952).

Para facilitar a visualização, as sentenças (15)-(18) estão reescritas abaixo, com a descrição das cavidades orais das consoantes nos moldes da geometria de traços:

\begin{tabular}{|c|c|c|c|}
\hline (19) tape(TE) DA porta & /t/ [coronal, -contínuo] & + & $/ \mathrm{d} /$ [coronal, -continuo] \\
\hline (20) lógi(CO) QUE não & $/ \mathrm{k} /$ [dorsal, -continuo] & + & /k/ [dorsal, -continuo] \\
\hline (21) quei(JO) saboroso & /3/ [coronal, +continuo] & + & /s/ [coronal, +contínuo] \\
\hline$(22)^{*}$ esco(VA) SEparada & /V/ [labial, +contínuo] & + & /s/ [coronal, +contínuo] \\
\hline
\end{tabular}

Nos exemplos (19)-(22) acima, os traços de ponto de C e de [contínuo] dão conta de 
descrever as características segmentais de queda de sílaba: em (19), há duas coronais [-contínuo]; em (20), o contexto /k + k/ é formado por duas dorsais [-contínuo]; no exemplo (21), há, novamente, duas coronais, desta vez, o traço para ambas as consoantes é [+contínuo]; ${ }^{17}$ finalmente, em (22), há uma labial / $/$ seguida de uma coronal /s/, e ambas são [+contínuo]. Assim, o único caso em que há bloqueio de queda de sílaba é (22), em que o ponto de $\mathrm{C}$ das consoantes é diferente (labial seguida de coronal).

Clements \& Hume (1995: 267) defendem que há diferentes maneiras de os traços se relacionarem, como representado no Gráfico 1:
a) $x$ domina $y$
b) y domina $x$
c) x e y são irmãos
d) x e y formam um nó
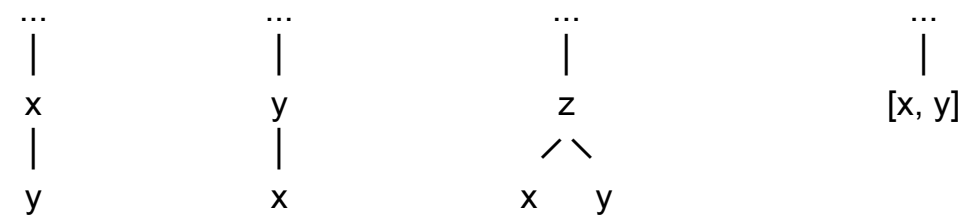

Gráfico 1 - Relação entre constituintes na geometria de traços

Em a), há uma relação de dominância, já que $x$ domina $y$, em b) a relação é a mesma, mas, desta vez, $y$ domina $x$, em c), um único traço $z$ domina $x$ e $y$, e estes dois são nós irmãos; finalmente, em d), $x$ e $y$ formam um único nó.

Com base nesses quatro modos de ligação que pode haver entre os constituintes, Clements \& Hume (1995: 292) propõem uma árvore de traços fonológicos, organizados de acordo com a geometria (adaptada) dada a seguir, em que estão assinalados os nós relevantes a este estudo:

\footnotetext{
17 Note que em (21) a diferença entre as consoantes abaixo do traço coronal parece não importar: /3/ é [anterior, +distribuído] e /s/ é [+anterior, -distribuído] e a queda de sílaba é gramatical (cf. Leal 2006).
} 


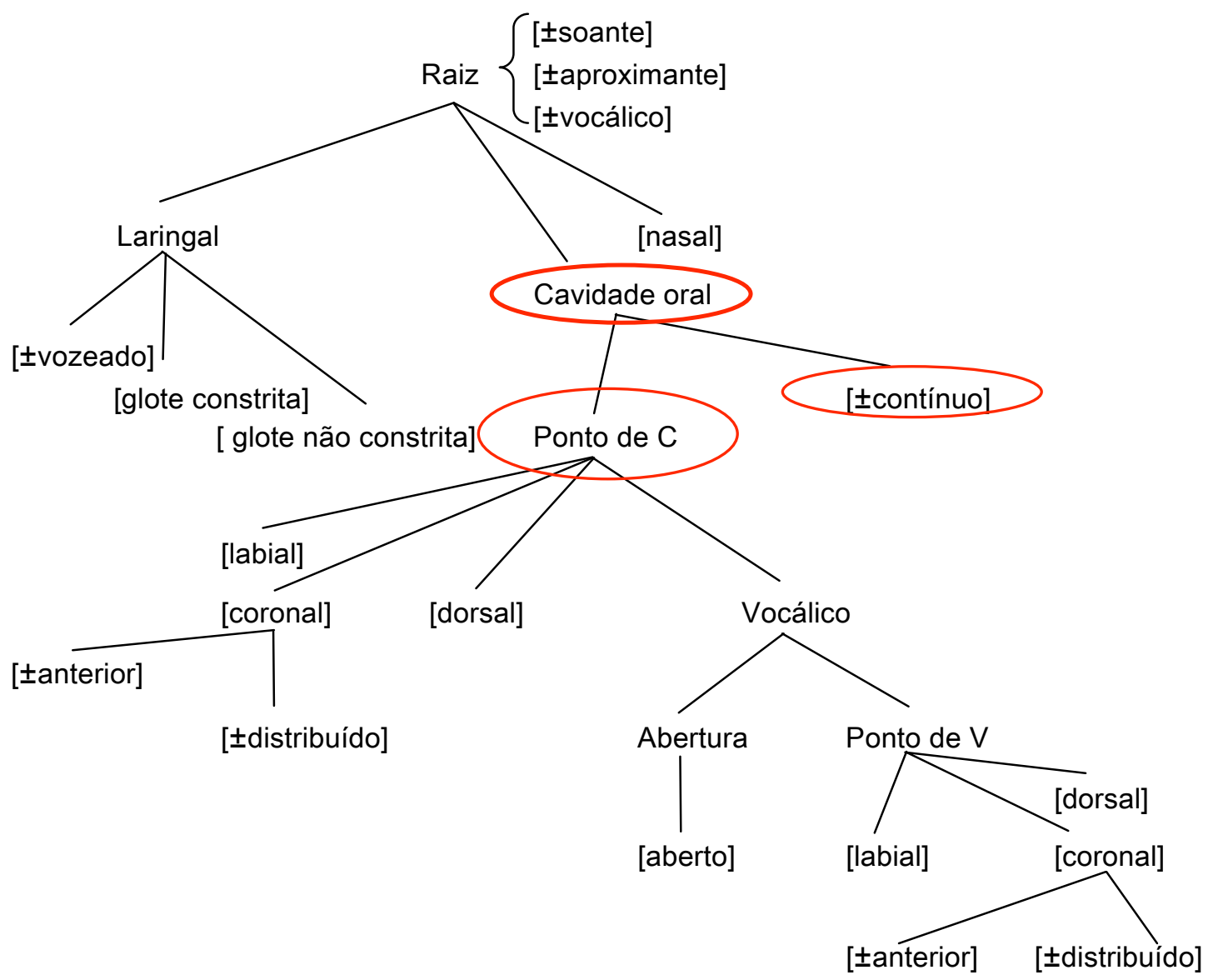

Gráfico 2 - Geometria de traços (adaptado de Clements \& Hume 1995: 292)

Os traços mais importantes para a definição do processo aqui em estudo são os nós irmãos Ponto de C e [contínuo] (cf. Leal 2006), ambos dominados pelo nó de Cavidade Oral, que aparecem destacados no Gráfico 2. Os traços na representação arbórea acima estão organizados de modo a implicar que, se uma regra fonológica ocorre em um determinado nó, esta mesma regra se aplica a todos os seus nós dominados (Clements \& Hume 1995: 251). Clements \& Hume (1995: 250) propõem ainda que a organização dos traços deve obedecer ao seguinte princípio:

Phonological rules perform single operations only. (grifo meu)

Assim, regras fonológicas se aplicam uma única vez (ou seja, executam uma única operação). 
Portanto, o constituinte mais importante no presente trabalho é a cavidade oral, pois é neste nó ${ }^{18}$ que estão as informações de um contexto que permite a queda de sílaba (para os casos de bloqueio, cf. subseção 5.1 e Leal 2006).

Assim, a queda de sílaba deve "olhar" a cavidade oral para identificar semelhança entre os segmentos; de outra forma, seriam 2 aplicações: primeiro, para ponto de C, e outra para [contínuo]. A relação entre a cavidade oral, ponto de C e [contínuo] é capturada na representação pelo item c) do Gráfico 1 , já que cavidade oral domina ponto de $\mathrm{C}$ e [contínuo], e estes dois são nós irmãos - em outras palavras, se o processo se aplica na cavidade oral, reflete diretamente nos dois nós abaixo dele.

Para exemplificar a geometria com a queda de sílaba, tomamos um dos dados de Leal (2006: 101). No sintagma ...na fren(Te) Da casa dela, o contexto consonantal para aplicação de apagamento é $/ t+d /$, com aplicação do processo. A seguir, apresento a geometria destas duas consoantes:

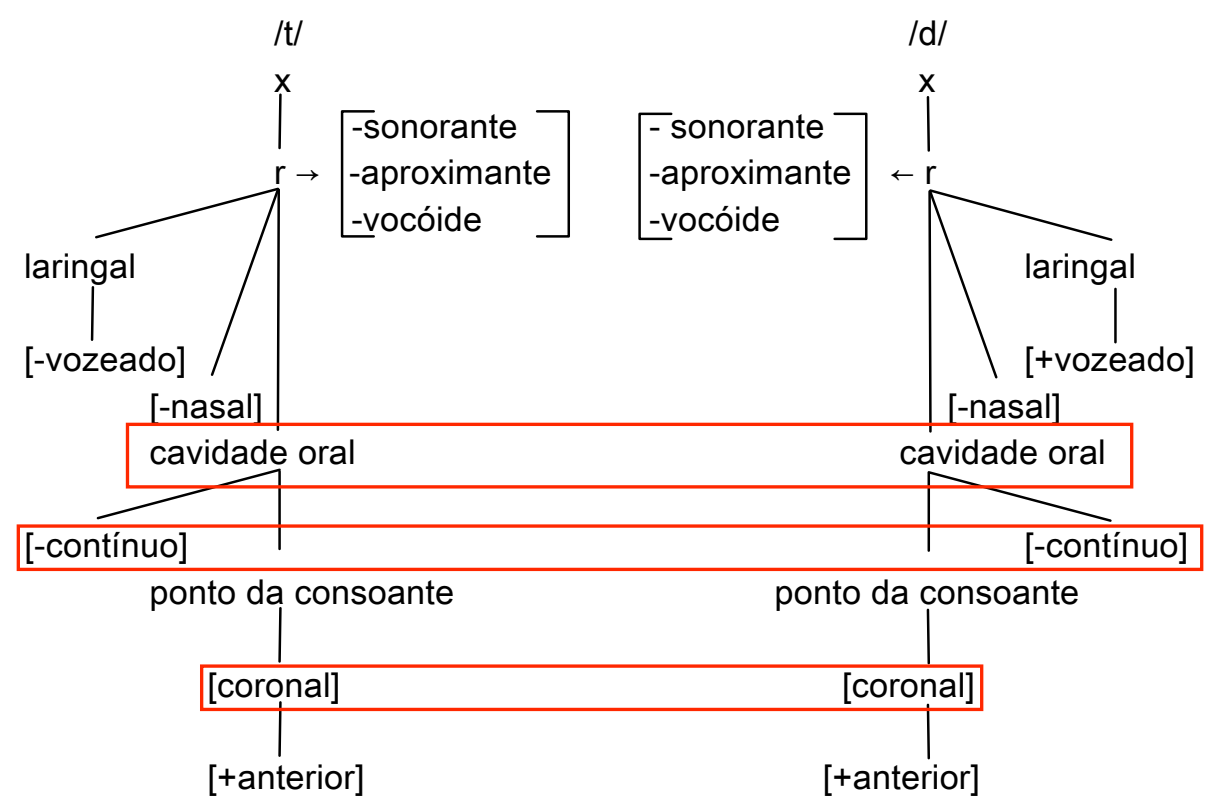

Gráfico 3 - Organização interna de traços das consoantes /t/ e /d/

A cavidade oral destacada no gráfico acima é o nó que atua como gatilho (trigger) no processo fonológico em estudo: se os traços de cavidade oral forem iguais nas consoantes,

18 Para uma proposta alternativa, cf. Sagey (1986). 
há possibilidade de queda, se a cavidade oral das consoantes for diferente, o processo nunca ocorre. ${ }^{19}$

Outra vantagem da geometria de traços na análise do corpus é a uniformização que se obtém para descrever consoantes e vogais, uma vez que ambos os tipos de segmentos são definidos da mesma forma. No exemplo (23), há 4 segmentos coronais no contexto /te + de/; em (24), as consoantes são coronais, mas as vogais são [dorso-labial]:20

(23) ...um paco(TE) DE feijão, tá ligado?

/te + de/: $\quad$ C1: coronal; V1: coronal

(24) ...fo(TO) DO nariz, queixo...

/to + do/: $\quad$ C1: coronal; V1: dorso-labial
(ALES)

C2: coronal; V2: coronal

(ALES)

C2: coronal; V2: dorso-labial

Como se pode observar em (23) e (24), há possibilidade de queda de sílaba mesmo que os pontos de $C$ das consoantes e das vogais sejam diferentes, como ocorre em (24) (as consoantes são coronais, enquanto que as vogais têm os traços [dorsal, labial] ou [dorsolabial] - na terminologia utilizada nesta tese -, e a queda de sílaba é gramatical).

\subsubsection{A estrutura silábica (do português brasileiro)}

Uma grande parte dos processos em português leva em conta a estrutura das sílabas - por exemplo, Bisol (1992) mostra que uma sílaba pesada final atrai o acento; Quednau (1993) aponta que a velarização ([ł]) ou vocalização ([w]) das laterais ([l]), no Rio Grande do Sul, só ocorre em posição de coda de sílaba.

Alkmin \& Gomes (1982) defendem que a haplologia só ocorre com a primeira sílaba com estrutura CV (e a segunda sílaba pode ter coda) - cf. exemplos (25) e (26) a seguir. Contudo, Battisti (2004), Pavezi (2006a) e Leal (2006) encontraram casos em que a sílaba

\footnotetext{
19 Não estamos dizendo, com isso, que a queda de sílaba seja um processo de geometria de traços. Como vimos nos exemplos citados até o momento, toda a sílaba é elidida, e não apenas um segmento. No entanto, é de se chamar a atenção que a variação dialetal leva em conta os valores abaixo do nó de cavidade oral, mostrando que o processo vai além do segmento, e a geometria dos segmentos envolvidos deve ser levada em conta. Ver também discussão na subseção 9.4 .

20 Exemplos do corpus de Leal (2006: 102).
} 
sujeita ao apagamento não é uma CV, mas sim CCV (ver (27), de Pavezi 2006a: 33), como exemplificado a seguir: 21
(25) CV+ CV:
limi(TE) DE palavra
(26) $C V+C V C$ :
lei(TE) TEMperado
(27) CCV+ CV:
cen(TRO) DE processamento de dados

Este fato aponta que há uma organização silábica que deve ser considerada em algumas regras fonológicas.

A teoria que assumimos para a estrutura silábica é Selkirk (1982), em que a sílaba subdivide-se hierarquicamente em ataque e rima; estes constituintes, por sua vez, podem ser novamente subdivididos em outros constituintes binários (núcleo e coda), como representando a seguir (do exemplo de Selkirk 1982: 331):

(28) Representação silábica da palavra flounce /flawns/

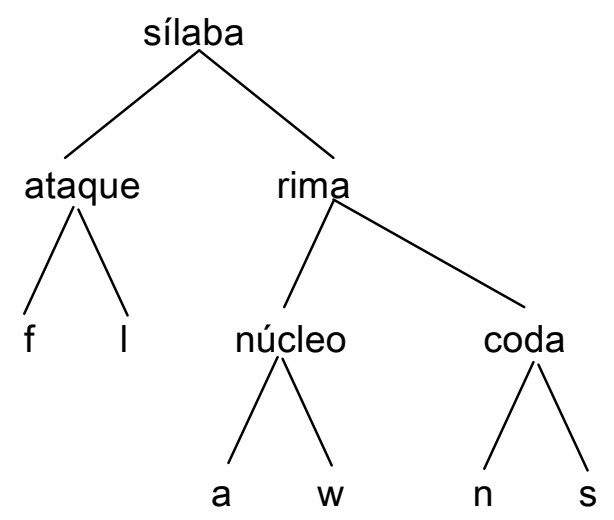

Um dos pontos menos controversos relacionados à estrutura interna da sílaba é o ataque, já que pode ser facilmente comprovado que os segmentos precedentes aos vocálicos em sílabas CCV formam uma unidade: nas diferentes línguas que distinguem sílabas pesadas e sílabas leves para marcação de acento (como no português), não importa se o ataque é ramificado ou não, sempre contará como uma mora (Hayes 1995). Para exemplificar, observem-se as últimas sílabas $/ \mathrm{ko} / \mathrm{e} / \mathrm{kro} /$ dos exemplos abaixo, com

21 Os exemplos (25) e (26) são de Alkmim \& Gomes (1982: 48) e (27)) é do corpus de Pavezi (2006a: 33). 
duas palavras trocaicas similares:

(29) saco /'sa.ko/

(30) sacro /'sa.kro/ sílaba /ko/: CV, não atrai acento

sílaba /kro/: CCV, não atrai acento

Em (29) e (30), as sílabas fortes são leves, e o ataque ramificado em /kro/ de (30) não atrai acento. Entretanto, se o segmento /r/ estiver em posição de coda, a sílaba atrai o acento no português:

(31) fato /'fa.to/

(32) fator /fa.'tor/ e não */'fa.tor/ sílaba /to/: CV, não atrai acento

sílaba /tor/: CVC, atrai acento

Em (31), ambas as sílabas são leves; em (32), o /r/ em coda torna a sílaba pesada, atraindo o acento da palavra.

Para os casos de ditongos crescentes, assumimos a proposta de Bisol (1989), para quem a posição do glide depende se ele é leve (cf. (33)) ou verdadeiro (ver (34)) (p. 189):

(33) peixe $>$ pe(i)xe $\rightarrow$ ditongo leve, rima simples

(34) peito > *pe(i)to $\rightarrow$ ditongo pesado (verdadeiro), rima complexa

Os ditongos leves são aqueles que podem ser reduzidos a uma única vogal e por isso a autora advoga serem fonéticos e não preencherem uma posição na estrutura silábica (apenas na melódica) - em (33) portanto, a primeira sílaba é uma CV. Os ditongos verdadeiros, por outro lado, não são passíveis de monotongação, e por isso Bisol sugere serem sílabas com um segmento pós-nuclear. Para estes ditongos, assumimos a proposta de Câmara Jr (1970) (cf. também Cristófaro-Silva 1999, Lee 1999)22 de que o glide preenche a posição de núcleo (a não ser que o glide seja resultado de uma líquida vocalizada, quando então preenche a coda - Camara Jr. 1969: 29-30). O argumento dos autores baseia-se no fato de que seguindo-se ditongos (verdadeiros) é possível uma sílaba iniciada pelo segmento ambissilábico /r/ (cf. (35)), o que não ocorre com sílabas em que ${ }^{22}$ Para análise alternativa, Cf. Wetzels (2007). 
claramente tem-se um segmento em coda (ver (36)):
(35) Cairo > Cai/r/o
/r/ fraco ambissilábico
CVVrV
(36) Israel > is/h/ael, e não *is/r/ael /r/ forte
CVC.CV

A mesma questão da distribucionalidade do / $r /$ ambissilábico nos auxilia na interpretação das vogais nasalizadas em português. Como se pode observar em (37), não é possível o /r/ forte seguindo uma sílaba com vogal nasalizada.

(37) tenro > ten/h/o, e não *ten/r/o /r/ forte CVC.CV

Assim, assumimos que a nasal também preenche a posição de coda de sílaba.

As vogais nasalizadas foram codificadas como orais, levando-se em conta o nível subjacente, já que consideramos que há estes tipos de segmentos somente no nível fonético no português (cf. Camara Jr. 1970 e Wetzels 1997, 2000). ${ }^{23}$ Assim, é importante discutir como foi tratada a nasalidade no presente estudo. Nos exemplos a seguir, podemos observar vogais nasalizadas por regra fonológica (cf. (38)) e por regra fonética (ver (39)):
(38) canto: /kaNto/ > [kẽntu]
nasalização fonológica
(39) cano: /kano/ > [kẽnu]
nasalização fonética

\begin{abstract}
23 Assumimos que o inventário fonológico vocálico do português é oral (não há vogais nasais subjacentes), e que estes segmentos podem ser nasalizados dos dois modos apresentados em (38) e (39). Nos casos como em (38), a primeira sílaba tem uma estrutura CVN e é, portanto, pesada. Um argumento para a existência de uma nasal subjacente é a distribuição do /r/ forte e do /r/ fraco no português (por exemplo, [h] forte e [r] fraco, como em carro ca[h]o e caro ca[r]o) também é um indicativo da presença de uma nasal subjacente, já que só há /r/ forte antecedido por nasal, e nunca de /r/ fraco (Camara Jr. 1970, Wetzels 1997, 2000). O /r/ fraco é ambissilábico: está no ataque de uma sílaba e também na coda da anterior, impossibilitando a presença de uma nasal nessa posição - somente há palavras como genro, nunca *gen[r]o no português brasileiro. Um terceiro argumento de Camara Jr. (1970) é que não há vogal nasal em hiato: ou a nasalidade desaparece, como em boa (que provém de bona), ou a consoante nasal vai para a sílaba seguinte, como em valentão > valentona ou nem um > nenhum. "Assim, não haver vogal nasal em hiato, dentro de um vocábulo, equivale a dizer que o arquifonema nasal, se subsiste, se comporta como qualquer consoante nasal intervocálica: pertence à sílaba seguinte (u-ma, e não um-a, como a-sa, a-ço, a-la, a-ra etc)" (Camara Jr. 1970: 60). Finalmente, Camara Jr. (1970) explica que, em casos de distinção fonológica, como em minto e mito, não é a ressonância nasal da vogal que gera o contraste, mas sim o travamento da consoante nasal, como em sem mana (com travamento) e semana (sem travamento).
\end{abstract}


Em (38), há uma sequência de 5 segmentos fonológicos kaNto, em que uma consoante $/ \mathrm{N} /$ subjacente passa o traço [nasal] à vogal anterior, ou seja, a vogal é nasalizada por estar em contato ou com uma nasal tautossilábica subjacente - uma regra fonológica, como representado na geometria em (40):

(40) Nível fonológico: /kaN.to/

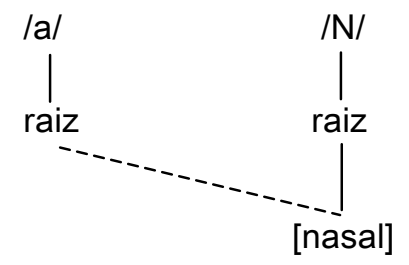

Em (38), há 4 segmentos fonológicos em cano, sem travamento da sílaba, e a vogal recebe o traço [nasal] a partir da produção (fonética) da consoante [n], isto é, o traço [+nasal] de [n] (uma nasal heterossilábica) se espalha para a vogal anterior, decorrente da coarticulação entre /a/ oral seguido de /n/, como representado na geometria em (41) abaixo:

(41) Nível fonético: [kẽ.nひ]

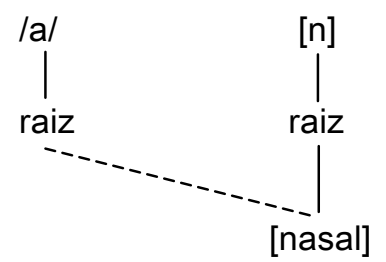

Assim, a partir do exposto nesta subseção, seguimos a teoria de representação de estrutura silábica de Selkirk (1982), a análise de Bisol (1989) para ditongos no português brasileiro, e as propostas de Camara Jr. (1970) e Wetzels $(1997,2000)$ para a nasalização de vogais.

\subsubsection{Acento e estrutura métrica}

Inúmeros processos fonológicos levam em conta a estrutura métrica ou ao menos o tipo de proeminência envolvida no contexto. A retração acentual, por exemplo, ocorre quando duas sílabas portadoras de acento primário estão adjacentes (cf. Abousalah 1997, 
Santos 2002, entre outros), enquanto que a degeminação pode ocorrer se a primeira sílaba for forte, como exemplificam Komatsu \& Santos (2007: 225) decidi estudar > [desi'dzistu'dar] - cf. também Bisol (1996, 2000, 2003); Tenani (2002); Veloso (2003). Defende-se que muitos destes processos ocorrem para otimizar a alternância rítmica em um dado contexto, alternando-se sílabas fracas e fortes.

De acordo com Hayes (1995: 01), a estrutura rítmica de uma língua é a expressão de seus padrões acentuais, ou seja, é o modo com que os acentos se organizam na fonologia; e cabe à teoria métrica resolver como são gerados e como se organizam no sistema fonológico (cf. Liberman \& Prince 1977, Hayes 1995, Fudge 1999). Hayes (1995: 377-8) explica que a classificação dos acentos é relacional:

(...) a strong beat is not strong to some absolute degree, but only in relation to other beats in the same rhythmic structure.

Galves \& Abaurre (1996) e Collischonn (2007) definem 3 graus de acento para o português brasileiro, dentre os quais citamos dois: (i) o acento primário (proeminência mais forte de uma palavra); e (ii) o acento secundário (qualquer outra proeminência na cadeia (string) de sílabas, cujo domínio pode ser a palavra ou sequência de palavras)..24

Segundo Hayes (1995: 24), uma das principais características do acento primário é a culminância:

One distinctive phonological characteristic of stress is that it is normally culminative, in the sense that each word or phrase has a single strongest syllable bearing the main stress. (grifos do autor)

Assim sendo, uma palavra como abacaxi labaka'fi/ tem um acento mais forte em /' $\mathrm{f} /$ do que nas outras sílabas /abaka/.

No entanto, podemos notar que na sequência labaka/ as sílabas também têm proeminências diferentes. Neste exemplo há outra uma proeminência, que pode estar na

24 O terceiro grau de acento apresentado por Galves \& Abaurre (1996) e Collischonn (2007) é chamado de frasal (ou principal), que é atribuído a uma sequência de palavras (tanto sintagmas quanto sentenças). Galves \& Abaurre (1996) explicam que "O acento principal de sintagma deve necessariamente corresponder a uma sílaba previamente marcada como portadora de acento primário de palavra." 
primeira ou na segunda sílaba: /,abaka'fi/ ou /a,baka'fi/ (Sandalo \& Abaurre 2007: 150). Esta segunda proeminência é conhecida como acento secundário. As autoras explicam que o padrão no português brasileiro do acento secundário é binário, raramente violado; as exceções são os dátilos (como em /,abaka'/i/), mas não são obrigatórios. Sandalo \& Abaurre (2007) explicam que enquanto a atribuição do acento primário no português brasileiro e no europeu é o mesmo, os dois dialetos são diferentes no que concerne ao acento secundário (ou acento rítmico, cf. também Bisol 2000). No caso de abacaxi, é possível /,abaka'fi/ ou /a,baka'fi/ embora esta última produção seja a mais comum no português brasileiro. Os exemplos de Sandalo \& Abaurre (2007: 146) a seguir ilustram a distribuição de acentos secundários em contextos maiores do que a palavra no sintagma a modernização: ${ }^{25}$

(42) Português europeu: a) A moodernização foi satisfatória

b) A modernização foi satisfatória

(43) Português brasileiro: a) A modernização foi satisfatória

Observando-se os exemplos (42) e (43) de Sandalo \& Abaurre (2007: 146), notamos que há duas alternativas na atribuição de acento secundário no português europeu: na sílaba mo, em a modernização ou no clítico a modernização. Para o português brasileiro, só há uma possibilidade: a modernização. Assim, os exemplos (42) e (43) ilustram que não há a possibilidade de o determinante em *a modernização receber acento secundário no português brasileiro, e este clítico fonológico pode ser então considerado mais fraco do que o secundário. ${ }^{26}$

Finalmente, a literatura é consensual em admitir que há sílabas que não portam acento - são as sílabas fracas. No caso de abacaxi, a sílaba ka ilustra uma sílaba fraca, quaisquer que sejam as posições do acento secundário. No caso de sequências maiores do que a palavra, há trabalhos defendem que há segmentos invisíveis ao acento (cf. Galves \&

\footnotetext{
25 Nos exemplos (42) e (43), os acentos fortes estão marcadas em negrito e as sílabas portadoras de acento secundário estão sublinhadas.

${ }^{26}$ Exceções de o clítico ser mais forte do que o acento secundário no português brasileiro são os casos de ênfase. Por exemplo, numa sentença como Comprei o quadro, o artigo pode ser enfatizado, Comprei o quadro para mostrar que "não foi qualquer quadro", mas um determinado quadro - e não outro.
} 
Abaurre 1996). Por exemplo, em (43) vimos que não é uma opção no português brasileiro que o acento secundário caia no determinante $a$, igualando-o à sílaba za; estes trabalhos definem os determinantes monossilábicos como clíticos fonológicos. Diversos trabalhos tratam da natureza híbrida do clítico fonológico (Nespor \& Vogel 1986: 145; Galves \& Abaurre 1996): é uma forma invisível a regras de acento e deve se apoiar a formas plenas; estão sujeitas frequentemente a reduções fonológicas segmentais. Em nota de rodapé, Hayes (1995: 377) explica:

(...) function words, such as pronouns, typically do not take phrasal stress. We assume this is to be accounted for by phonologically cliticizing them onto neighboring full words, as in Hayes (1989); thus they are not present as terminals for purposes of phrasal stress rules.

Hayes (2009: 271) exemplifica o clítico com a palavra the em the book [ðə buk]: o clítico fonológico [ðə] é desacentuado porque está adjacente a uma palavra de conteúdo [buk], passando fonologicamente a fazer parte da palavra de conteúdo. Ainda, o autor explica que se the for usada isoladamente, recebe um acento artificial, como em [ð^:] ou [ði:], obedecendo ao princípio da culminância. Hayes (1995) aponta que os determinantes não recebem acento primário. A partir dos exemplos de Sandalo \& Abaurre (2007) inferimos que estes clíticos também não podem portar acento secundário no português brasileiro. Assim, até aqui, temos uma distinção de 3 graus de acento: comparando-se o acento primário e o secundário, temos que este é mais fraco do que aquele; ao comparar, de um lado, o primário e o secundário e, de outro, o clítico, notamos que ambos são mais fortes do que o clítico, pois este não tem proeminência (Hayes 1995, Galves \& Abaurre 1996). Dado que o clítico e a sílaba fraca não têm proeminência, a pergunta que se coloca é: há alguma diferença em grau de acento entre clíticos fonológicos e sílabas fracas?

Observe os exemplos a seguir, no dialeto campineiro:
(44) a) pretônica:
semente $>\mathrm{s}[\mathrm{e}] \mathrm{mente}$
${ }^{*}$ s[i]mente
b) clítico:
se mente $>$ s[i]mente 
(45) a) pretônica: o Alckmin é bom devoto > d[e]voto *d[i]voto

b) clítico: o Alckmin é bom de voto > d[i]voto

Comparando-se a sílaba pretônicas de SEmente em (44)a) com o clítico em SE mente em (44)b), parece não haver redução de /e/ > [i] nas pretônicas, somente no clítico fonológico. Da mesma forma, o exemplo em (45)a) parece não reduzir, diferente de (45)b). Assumimos que não há mudança de qualidade da vogal numa sílaba pretônica, enquanto que um clítico parece reduzir.

Passamos a comparar agora sílabas postônicas e clíticos. Os exemplos a seguir são ditos populares e que, a depender do dialeto, podem ser produzidos diferentemente:

(46) Um homem estava no morro a /ca.'va.lo/.

a) postônica de cavalO: cava[lu]

b) clítico de cavá-IO: caval[o]

(47) Hoje é domingo, /'pe.de/ cachimbo

a) postônica de pedE: $\quad$ pe[dzI]

b) clítico de pé $d E$ : pé[de]

Num teste piloto de julgamento de gramaticalidade, notamos uma direção no julgamento: quando há neutralização da vogal, a sílaba final tanto pode ser a última sílaba de uma palavra, como um clítico. Por outro lado, se não há neutralização, a sílaba final é interpretada como clítico. Nunca é o caso de se interpretar a sílaba que não sofreu neutralização como parte do radical. Isto é, em (46), quando lo é produzida como [lv], tanto pode ter uma interpretação de cavalo quanto cavá-lo; por outro lado, quando lo é produzida como [lo], a primeira interpretação é de cavá-lo, e não de cavalo.

Da mesma forma, também é diferente a realização de de apresentada no exemplo (47): quando há alçamento de /e/ > [i], há duas interpretações possíveis: pé de ou pede; se não ocorre o alçamento e a produção fica [de], a primeira interpretação é que a sequência é 
pé de.

Em resumo, tanto para clíticos vs. pretônicas quanto clíticos vs. postônicas, parece haver uma diferença no comportamento de clíticos e sílabas fracas. ${ }^{27}$ Tendo em vista estes fatos, trabalharei com uma hierarquia com quatro graus de acento, os dois primeiros acentuados, e os dois últimos, desacentuados:

(48) Hierarquia de acento:

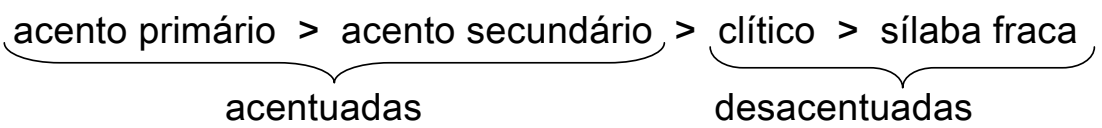

Além da geração e tipos de acentos, uma questão importante ao se lidar com processos que alteram a quantidade de sílabas numa cadeia é o que motiva esta alteração. Especificamente para a queda de sílaba, no nível segmental advoga-se o OCP como motivador da aplicação do processo. Do ponto de vista métrico, um outro princípio pode estar em ação, o Principle of Rhythmic Alternation (PAR) (cf. em 2.1 a formulação provisória do princípio). Selkirk (1984: 52) propõe que ele seja formulado do seguinte modo:

The Principle of Rhythmic Alternation

a. Every strong position on a metrical level $n$ should be followed by at least one weak position on that level.

b. Any weak position on a metrical level $n$ may be preceded by at most one weak position on that level.

Tomando-se $n$ como sentença, por exemplo, temos que uma posição forte deve ser seguida de pelo menos uma fraca na sentença; uma posição fraca pode ser seguida, no máximo, por uma posição fraca na sentença.

27 A sílaba postônica é prosodicamente mais fraca do que pretônica (cf. Bisol 2003: 187, Leal \& Santos 2010); assim, a pretônica deve reduzir menos. É o que podemos observar se compararmos os exemplos (44)a) e (45)a), de um lado, (46)a) e (47)a), de outro: as vogais das pretônicas em SEmente e em DEvoto parecem não reduzir, enquanto que as vogais das postônicas de cavaLO > cava[lu] e peDE > pe[dzI] são reduzidas. Com relação aos clíticos, a expectativa é que o comportamento seja o mesmo, sem importar a posição com relação à postônica. No entanto, comparando-se os clíticos que aparecem antes da sílaba forte em (44)b) e (45)b), de um lado, e aqueles que estão depois da sílaba forte em (46)b) e (47)b), vemos que, no primeiro caso, há redução da vogal (SE mente > s[i]mente e $D E$ voto > d[i]voto), enquanto que o mesmo não ocorre no segundo caso (caváLO > caval[o] e pé DE > pé[de]). Não temos uma explicação para este fato, mas é um tema a ser trabalhado futuramente. Agradeço à Prof ${ }^{a} \mathrm{Dr}^{\mathrm{a}}$ Luciani Tenani por me chamar a atenção a esta questão. 
Observe o exemplo a seguir:

(49) Organização acentual no sintagma faculdaDE DE medicina

$$
\begin{array}{lllllllllll}
\text { fa } & \text { cul } & \text { da } & \text { DE } & \text { DE } & \text { me } & \text { di } & \text { ci } & \text { na } & \\
& & & & & & & & & \\
x & \bullet & x & \bullet & \bullet & x & \bullet & x & \bullet & \text { estrutura rítmica }
\end{array}
$$

Em (49), a estrutura rítmica resulta em um lapso acentual, um encontro de duas sílabas fracas /de + de/ (marcadas em vermelho). Lapsos e choques acentuais tendem a ser evitados nas línguas, ou seja, de um modo geral, há uma grande tendência de regularidade na alternância de sílabas fortes e fracas.

Assim, uma das soluções para resolver o lapso acentual em (49) é apagar a sílaba à esquerda do sintagma, reestruturado do seguinte modo:

(50) Reestruturação rítmica no sintagma faculda(DE) DE medicina

$$
\begin{aligned}
& \text { fa cul da (DE) DE me di ci na } \\
& \mathrm{x} \quad \mathrm{x} \quad \mathrm{x} \mathrm{x} \quad \mathrm{x} \quad \mathrm{x} \text { estrutura rítmica reestruturada }
\end{aligned}
$$

Com a aplicação de queda de sílaba em (50), o lapso da última sílaba de faculdade e da preposição de se resolve, já que os dois tempos das sílabas /de + de/ passam a ter uma única batida na produção da fala.

\subsubsection{Hierarquia prosódica: a interface fonologia e outros níveis gramaticais}

Uma questão importante a se levantar é se a queda de sílaba é um fenômeno puramente fonológico ou se leva em conta informações de outros componentes gramaticais, como acontece na retração acentual, por exemplo (Cf. Abousalah 1997; Santos 2002, 2003a, 2003b). Alguns trabalhos sobre haplologia apontam que esta ocorre preferencialmente em alguns domínios prosódicos (mais especificamente a frase fonológica, cf. Capítulo III e citações ali referidas).

Em linhas gerais, a hierarquia prosódica é a interface entre a fonologia com outros 
níveis da gramática, em que os sons da fala estão organizados em unidades maiores, como apresento abaixo:

(51) Organização dos sons em constituintes prosódicos:

(U...) U enunciado(s)...

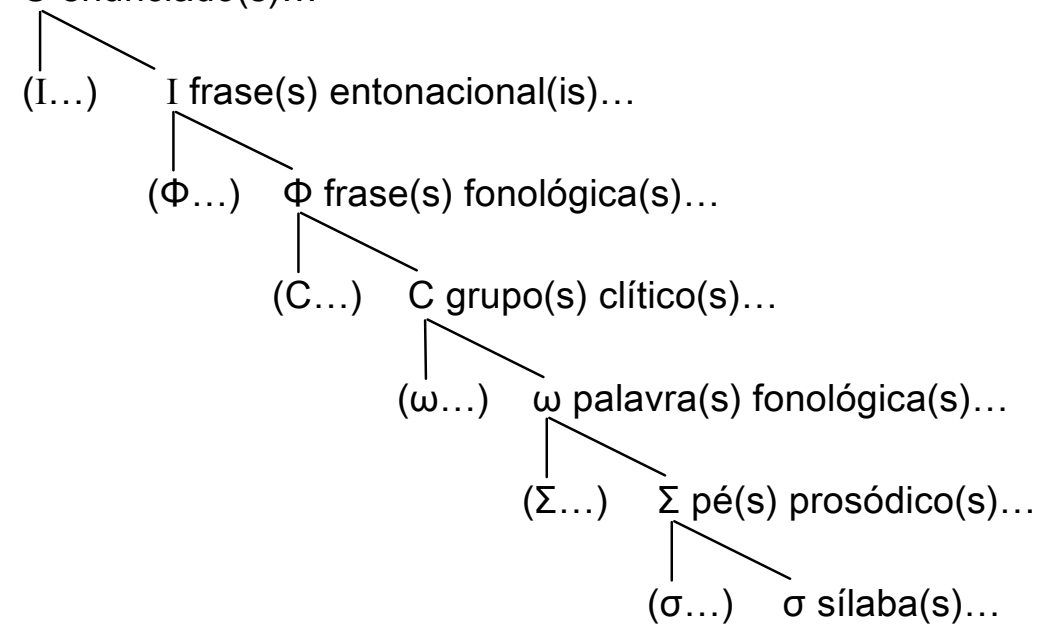

A representação acima corresponde aos níveis prosódicos definidos em Nespor \& Vogel (1986). Para Selkirk (1984), o número de níveis é 5 e não 7: não há o nível de palavra fonológica, somente de grupo clítico (chamado de palavra prosódica pela autora), e nem o nível de enunciado. Assim, a principal diferença entre as duas abordagens é se há ou não um clítico na organização prosódica, como exemplificado a seguir:

(52) Sintagma: perto de lá

\begin{tabular}{|c|c|c|c|c|c|c|c|c|c|}
\hline per & to & de & lá & Nespor \& Vogel (1986) & per & to & de & lá & Selkirk (1984) \\
\hline$[\bullet$ & - & • & $\mathrm{x}]$ & frase entonacional & {$[\cdot$} & $\bullet$ & • & $x]$ & frase entonacional \\
\hline$[\bullet$ & - & • & $\mathrm{x}]$ & frase fonológica & {$[\cdot$} & • & • & $x]$ & frase fonológica \\
\hline$[x$ & $\bullet]$ & {$[\cdot$} & $x]$ & grupo clítico & $\int^{2}$ & . 1 & & & nalayrn nrocóding \\
\hline$[x$ & •] & {$[x]$} & {$[x]$} & palavra fonológica & {$[x$} & •] & $L$ & $J$ & paravia piosocica \\
\hline$[x$ & •] & {$[x]$} & {$[x]$} & pé fonológico & {$[x$} & •] & {$[x]$} & {$[\mathrm{x}]$} & pé fonológico \\
\hline$[x]$ & {$[\mathrm{x}]$} & {$[x]$} & {$[x]$} & sílaba & {$[x]$} & {$[x]$} & {$[x]$} & {$[x]$} & sílaba \\
\hline
\end{tabular}

O item lexical de em (52) é uma palavra fonológica para Nespor \& Vogel (1986), já que recebe acento neste nível prosódico. No entanto, no grupo clítico, de não é acentuado 
e se agrega à palavra que possui acento neste nível, lá (note-se que lá não é um clítico, já que recebe acento neste nível), formando o constituinte [de lá] grupo clítico. Por outro lado, a palavra prosódica para Selkirk (1984) equivale ao constituinte que Nespor \& Vogel (1986) chamam de grupo clítico: [de lá] palaura fonológica (marcado em itálico nas duas grades em (52)). Neste nível, lá é acentuado e de não é. Neste trabalho, assumimos a teoria de Nespor \& Vogel (1986), dado que esta inclui a de Selkirk (apesar de não haver diferença entre utilizar a teoria de Selkirk (1984) e Nespor \& Vogel (1986) no presente trabalho; assim, chamamos o nível mais baixo estudado de grupo clítico - e não palavra prosódica). ${ }^{28}$

Os níveis prosódicos de interesse para este trabalho são aqueles acima da palavra fonológica, quais sejam: o grupo clítico $(C)$, a frase fonológica $(\Phi)$ e a frase entonacional (I). Nespor \& Vogel (1986: 07) afirmam que a construção de cada um dos níveis é determinada pelas mesmas regras, da seguinte forma:

\section{Prosodic Constituent Construction}

Join into an $n$-ary branching $X^{P}$ all $X^{P-1}$ included in a string delimited by the definition of the domain of $X^{P}$.

Em outras palavras, um constituinte prosódico é formado pelos constituintes que estão logo abaixo dele - ou seja, um grupo clítico é formado por palavra(s) fonológica(s); uma frase fonológica é constituída de grupo(s) clítico(s); e uma frase entonacional contém frase(s) fonológica(s).

Apresento abaixo a formação dos três constituintes estudados no presente trabalho:

(53) Algoritmo de formação do Grupo Clítico (Nespor \& Vogel 1986: 155)

I. C domain

The domain of $C$ consists of a $\omega$ containing an independent (i.e. nonclitic) word plus any adjacent $\omega$ s containing

a. a DCL [directional clitic], or

b. a CL [Clitic] such that there is no possible host with which it shares more than category memberships.

\footnotetext{
28 Não há contexto de queda de sílaba entre duas palavras fonológicas (nos termos de Nespor \& Vogel 1986), e o nível mais baixo da hierarquia a ser considerado para análise do corpus foi o de grupos clíticos - cf. subseção 4.1.4.1.4.
} 
(54) Algoritmo de formação da Frase Fonológica (Nespor \& Vogel 1986: 168)

I. $\Phi$ domain

The domain of $\Phi$ consists of a $C$ which contains a lexical head $(X)$ and all $C$ s on its non-recursive ${ }^{29}$ side up to the $C$ that contains another head outside of the maximal projection of $\mathrm{X}$.

(55) Algoritmo de formação da Frase Entonacional

Intonational Phrase Formation (Nespor \& Vogel 1986: 189)

I. I Domain

An I domain may consist of

a. all the $s$ in a string that is not structurally attached to the sentence tree at the level of s-structure; or

b. any remaining sequence of adjacent $\mathrm{s}$ in a root sentence.

Especificamente sobre a frase fonológica, as autoras afirmam que pode haver uma reestruturação neste nível, de aplicação opcional ${ }^{30}$ cujo principal propósito é evitar frases fonológicas curtas:

(56) Reestruturação de frase fonológica (opcional)

A non-branching $\Phi$ which is the first complement of $X$ on its recursive side is joined into the $\Phi$ that contains $X$.

Na reestruturação da frase fonológica, não é formado um novo nível, pois a fronteira entre as duas frases fonológicas em questão é apagada, e o resultado é uma única frase fonológica:

(57) $\left.\left.[\text { [deserto }]_{c}\right]_{\Phi}[\text { [distante }]_{c}\right]_{\Phi}$

(58) [ [deserto] c [distante] c ] Фr frase fonológica

frase fonológica reestr.

29 O lado recursivo de uma língua é aquele em que são introduzidas palavras para gerar novas sentenças.

${ }^{30} \mathrm{~A}$ reestruturação é um parâmetro e, uma vez marcado (reestruturar ou não), é fixo numa determinada língua. Assim, opcional se refere a uma variação entre as línguas, uma vez que há línguas em que a reestruturação é obrigatória, outras em que é impossível e, ainda, outras em que é opcional (cf. Nespor \& Vogel 1986: 172-186). 
As duas frases fonológicas [deserto] $\Phi_{\phi}$ e [distante] $]_{\Phi}$ (marcadas em azul) podem ser reestruturadas em um único constituinte [deserto distante] $\Phi$ reestr (marcado em vermelho); a fronteira de frase fonológica entre elas é apagada e o que fica é uma fronteira de dois grupos clíticos - segundo Nespor \& Vogel (1986), há processos que podem ocorrer internos a um domínio, nos limites de um domínio ou entre domínios.

Como dissemos, a hierarquia prosódica resulta do mapeamento da fonologia com outros níveis da gramática: no grupo clítico, este mapeamento é feito entre o componente fonológico e o morfo-sintático; na frase fonológica, é entre a fonologia e a sintaxe; na frase entonacional, o mapeamento pode ser entre a fonologia e informações semânticas, sintáticas e de performance (como a taxa de elocução, o tamanho da sentença, etc). Embora a hierarquia prosódica seja construída a partir da relação entre a fonologia e outros níveis gramaticais, Nespor \& Vogel (1986) explicam que não há necessidade de isomorfia entre eles, como exemplifico no português:

(59) $\left.[\text { [linda }]_{\omega}[\text { mente }]_{\omega}\right]_{\mathrm{adv}}$

Em (59), há apenas uma elemento terminal na árvore sintática lindamente, enquanto que, prosodicamente, há duas palavras fonológicas, pois há acento primário em 'linda e outro em 'mente, (cf. Lee 1994).

Uma vez delineado o quadro teórico de fonologia, passamos a tratar, no próximo capítulo, da definição do processo fonológico. 


\section{CAPÍTULO III}

\section{A definição do processo de queda de sílaba}

Neste capítulo, descrevemos as características que definem a queda de sílaba no português brasileiro com base em análises encontradas tanto para esta língua quanto para outras, limitando-nos a processos sincrônicos de sândi externo (cf. Alkmim \& Gomes 1982, Battisti 2004, Tenani 2002, Pavezi 2006a e Leal 2006).

Geralmente, a elisão silábica (cf. Leal 2006) e a haplologia (Alkmim \& Gomes 1982, Battisti 2004, Tenani 2002, Pavezi 2006a e Leal 2006), dois processos de queda de sílaba, são tratados separadamente e a grande maioria dos trabalhos do português brasileiro apresentados nesta tese - que são a base para definirmos o processo - analisam a haplologia, apresentando restrições variadas para o processo. Estas restrições diferentes nas análises podem indicar que a implementação da queda de sílaba é diferente porque depende do dialeto estudado. Dos trabalhos sobre haplologia, Alkmim \& Gomes (1982) não reportam qual é o dialeto, afirmando logo no início do artigo (p. 44):

Pretendemos aqui dar uma contribuição ao estudo dos fenômenos de limite de palavra, área pouco explorada da fonologia portuguesa, em que pese a sua importância como ingrediente do que se pode chamar, impressionisticamente, o "sotaque brasileiro".

A interpretação que se tem da afirmação acima é que a haplologia teria as mesmas características em todos os dialetos do português brasileiro. Assim como Alkmim \& Gomes (1982), Bisol (2000) não define o dialeto, mas afirma que a base é o português brasileiro e, com o objetivo de analisar o ritmo, um dos processos fonológicos estudados pela autora é a haplologia. Outro trabalho sobre haplologia é o de Battisti (2004) que, com base no corpus VARSUL, analisa o dialeto de Porto Alegre. Os trabalhos de Tenani $(2002,2003)$ tratam do dialeto de São José do Rio Preto, também para haplologia. Pavezi (2006a, 2006b) analisa a haplologia nos dialetos de São José do Rio Preto, com base no IBORUNA-São José do Rio 
Preto, e de São Paulo, com base no NURC-SP. Finalmente, com o objetivo de analisar a elisão silábica e a haplologia, o dialeto estudado em Leal $(2006,2007)$ é o de Capivari.

Assim, chamamos a atenção para o fato de que as diferenças entre as propostas para a queda de sílaba podem estar relacionadas ao dialeto em estudo, ou seja, pode ser o caso de detectarmos diferenças entre a aplicação de queda de sílaba em diferentes cidades (casos de variação diatópica).

Leal (2006) argumenta que a elisão silábica e a haplologia, tratadas separadamente na literatura, são um único processo fonológico - a queda de sílaba - em Capivari, com as mesmas propriedades nos níveis segmental, prosódico e métrico. Assim, trataremos as duas separadamente (haplologia em 3.1 e elisão silábica em 3.2), e em 3.3 apresentamos a análise de Leal (2006).

\subsection{Elisão silábica}

Para definirmos a elisão silábica, observe os exemplos abaixo, todos do teste de Leal (2006):

$\begin{array}{llll}(60) / t+n / & \text { consoan(TE) NAsalizada } & \text { conso['ẽ.na]salizada } & \text { (teste) } \\ (61) / z+z / & \text { bele(ZA) Glgantesca } & \text { be['le.3i]gantesca } & \text { (teste) } \\ (62) / k+p / & { }^{*} \text { mole(QUE) POderoso } & { }^{*} \text { mo['IE.po]deroso } & \text { (teste) } \\ (63) / s+d / & { }^{*} \text { crian(ÇA) Dlfícil } & { }^{*} \text { crian[di]fícil } & \text { (teste) }\end{array}$

No exemplo (60), o contexto consonantal $/ t+n /$ é formado por duas consoantes coronais [-contínuo, +anterior, -distribuído], em que a primeira é um segmento oral [-vozeado] e a segunda é uma nasal [+vozeado], e a queda de sílaba pode ser aplicada. ${ }^{31}$ No contexto /z + z/ em (61), há duas coronais [+contínuo, +vozeado], e há aplicação do processo, mesmo que o segmento /z/ seja [+anterior, -distribuído] e /3/ [-anterior,

\footnotetext{
31 Lembramos que as nasais são [+contínuo] na cavidade nasal, mas na cavidade oral são segmentos [-contínuo], e é esta última que dita se o processo pode ou não ocorrer. O traço [nasal] e o ponto de C coronal, no exemplo (60), estão em nós diferentes, seguindo-se a geometria de traços: o nó que domina [nasal] é a raiz do segmento, enquanto que o que domina o ponto de C é a cavidade oral (cf. Clements \& Hume 1995 e subseção 2.2.1 desta tese).
} 
+distribuído]. ${ }^{32}$ Em casos como (62), há dois segmentos [-contínuo] /k + p/, mas o ponto de C das consoantes é diferente (há uma dorsal seguida de uma coronal), e a aplicação do processo é agramatical, segundo Leal (2006). Em (63), há duas coronais /s $+\mathrm{d}$ /, a primeira é [-vozeado, +contínuo, +anterior, -distribuído] e a segunda é [+vozeado, -contínuo, +anterior, -distribuído] e aplicação do processo torna a sentença agramatical. Para facilitar a discussão que segue, apresento na tabela abaixo uma comparação dos traços internos das consoantes dos contextos (60)-(63):

Tabela 1 - Comparação dos traços internos de consoantes

\begin{tabular}{|c|c|c|c|c|c|}
\hline contexto & vozeamento & anterior, distribuído & ponto de C & contínuo & $\begin{array}{c}\text { possibilidade } \\
\text { de aplicação33 }\end{array}$ \\
\hline$/ \mathrm{t}+\mathrm{n} /$ & diferente & igual & $\begin{array}{c}\text { igual } \\
\text { [coronal] }\end{array}$ & $\begin{array}{c}\text { igual } \\
\text { [-contínuo] }\end{array}$ & sim \\
\hline$/ z+z /$ & igual & diferente & $\begin{array}{c}\text { igual } \\
\text { [coronal] }\end{array}$ & $\begin{array}{c}\text { igual } \\
{[+ \text { contínuo] }}\end{array}$ & sim \\
\hline$/ \mathrm{k}+\mathrm{p} /$ & igual & - & $\begin{array}{c}\text { diferente } \\
\text { [dorsal+labial] }\end{array}$ & $\begin{array}{c}\text { igual } \\
\text { [-contínuo] }\end{array}$ & não \\
\hline$/ \mathrm{s}+\mathrm{d} /$ & diferente & igual & $\begin{array}{c}\text { igual } \\
\text { [coronal] }\end{array}$ & $\begin{array}{c}\text { diferente } \\
\text { [+continuo]+[-contínuo] }\end{array}$ & não \\
\hline
\end{tabular}

Com relação a vozeamento, notamos que este traço não interfere no processo, já que nos casos em que as consoantes são diferentes (cf. contexto /t $+n /$ em (60)) ou iguais $(\operatorname{ver} / z+3 /$ em (61)) em [vozeamento], o processo pode ocorrer (cf. Alkmim \& Gomes 1982, Tenani 2002, Battisti 2004 e Pavezi 2006a). Os traços [anterior, distribuído] dizem respeito apenas às coronais (cf. nota 32) e pode haver aplicação do processo com valores iguais (cf. $/ t+n /$ em (60)) ou diferentes (ver / $z+3 /$ em (61)). Como se pode ver no contexto $/ k+p /$ em (62), há bloqueio do processo e, mesmo que tenham um valor igual para contínuo (ambas são [-contínuo]), os pontos de C são diferentes: há uma dorsal seguida de uma labial, o que

\footnotetext{
32 Veja que os traços [anterior, distribuído] se aplicam somente para as coronais, já que são nós irmãos dependentes do traço [coronal], que está abaixo deste nó na geometria - cf. subseção 2.2.1 desta tese e Clements \& Hume (1995: 292).

${ }^{33}$ A possibilidade de aplicação de queda de sílaba é estabelecida de acordo com os resultados do estudo de Leal (2006), ou seja, do dialeto capivariano.
} 
causa o bloqueio. Em /s+d/ (cf. exemplo (63)), o ponto de C é o mesmo [coronal], mas a primeira consoante é [+contínuo] e a segunda é [-contínuo] e o processo é bloqueado.

Assim, podemos observar que a aplicação da elisão silábica não é aleatória, já que os traços de cavidade oral (ponto de $C$ e contínuo) é o que restringe a regra: se as consoantes do contexto segmental não tiverem um mesmo ponto de $\mathrm{C}$ e um mesmo valor para o traço [contínuo], a implementação do processo é bloqueada, como exemplificado com os contextos (62) e (63) (cf. subseção 3.3).

Casos de elisão silábica são pouco estudados na literatura, e Alkmim \& Gomes (1982: 50) apontam, de maneira breve, que há alguns tipos de elisão silábica ${ }^{34}$ em que o resultado é obtido por efeito da próclise, como exemplificado a seguir: ${ }^{35}$

(64) poDE FAlar > po(DE) Falar ['po.fa.'la]

No entanto, não há como se considerar que a sílaba po de pode, resultante do apagamento silábico, seja um proclítico: clíticos fonológicos são palavras que não carregam acento acima da palavra, e que podem se juntar à direita (enclíticos) ou à esquerda (proclíticos) de palavras que possuem acento, como exemplificado abaixo:

$\begin{array}{ll}(65) \text { o menino }> & \left.[0]_{\omega}[\text { menino }]_{\omega}\right]_{c} \\ (66) \text { pegue-o }> & \left.[\text { [pegue- }]_{\omega}[0] \omega\right] c\end{array}$

Em (65), o determinante o é um clítico fonológico que se associa à palavra fonológica menino por efeito da próclise; em (66), o pronome o se associa à pegue, em decorrência da ênclise.

Retomando o exemplo de Alkmim \& Gomes (1982), observe as grades métricas a seguir:

\footnotetext{
34 Alkmim \& Gomes (1982) chamam o processo apresentado em (67) de redução; usamos aqui o termo 'elisão silábica' para contemplar a especificidade deste tipo de processo fonológico, diferenciando-o do uso genérico 'redução' - este termo é um hiperônimo, que abarca vários tipos de processos fonológicos (cf. Leal 2006: 11-4).

${ }^{35}$ Cf. também discussão em Leal (2006).
} 
(67) Sintagma pode falar

$$
\begin{aligned}
& {\left[\begin{array}{lll}
\cdot & - & x
\end{array}\right] \text { frase fonológica }} \\
& {\left[\begin{array}{ll}
x & \bullet
\end{array}\right]\left[\begin{array}{ll}
\bullet & x
\end{array}\right] \text { grupo clítico }} \\
& {\left[\begin{array}{ll}
x & \bullet
\end{array}\right]\left[\begin{array}{ll}
\bullet & x
\end{array}\right] \text { palavra fonológica }} \\
& \text { po de fa lar }
\end{aligned}
$$

(68) Sintagma po(de) falar

$$
\begin{array}{cccc}
{[\cdot} & \bullet & x] & \text { frase fonológica } \\
{[x]} & {[\cdot} & x] & \text { grupo clítico } \\
{[x]} & {[\bullet} & x] & \text { palavra fonológica } \\
\text { po } & \text { fa } & \text { lar } &
\end{array}
$$

Como representado em (67) e (68), a primeira sílaba de pode recebe acento nos níveis de palavra fonológica e de grupo clítico, não podendo ser considerada um clítico fonológico. Mesmo que se construa uma grade com apagamento da sílaba de de pode, cf. (68), [po] continua a receber acento nos níveis citados.

Com relação ao nível segmental do sintagma poDe Falar, observamos que tanto o ponto de C quanto o valor para [contínuo] (isto é, a cavidade oral) das consoantes $/ \mathrm{d}+\mathrm{f} /$ são diferentes: o primeiro segmento é uma coronal [-contínuo], enquanto que o segundo é uma labial [+contínuo] e, apesar destas diferenças, a queda de sílaba é gramatical. Estes tipos de dados são muito interessantes, e podem ser analisados pela proposta de difusão lexical (cf. Oliveira 1992 e Cristófaro 2001): podem ser palavras específicas em que uma mudança de som se aplica, ou seja, parecem ser marcadas lexicalmente para uma propensão a um determinado processo fonológico. ${ }^{36}$ No entanto, associar a queda de sílaba a processos fonológicos de difusão lexical foge ao escopo deste trabalho (cf. resultados do estudo piloto deste trabalho e a discussão na subseção 5.1).

\subsection{Haplologia}

Em linhas gerais, a haplologia é um processo de apagamento de sílabas, no qual o contexto segmental deve ser duas sílabas iguais ou semelhantes. Para o caso de semelhanças, as consoantes devem ser, no máximo, diferentes em [vozeamento]. Observe os exemplos a seguir, adaptados de Alkmim \& Gomes (1982: 48):

\footnotetext{
36 Oliveira (1992: 32) explica que a difusão lexical, "em sua essência, propõe que as mudanças sonoras sejam vistas como sendo lexicalmente graduais e foneticamente abruptas. O modelo da DL [difusão lexical] se opõe, portanto, ao modelo Neogramático (NG), que concebe as mudanças sonoras como sendo lexicalmente abruptas e foneticamente graduais."
} 

(69) $/ \mathrm{t}+\mathrm{t} /$
quanTO TRAbalho >
quan(TO) TRAbalho
$(70) / t+d /$
limiTE DE palavra >
$\operatorname{limi}(T E)$ DE palavra

Em (69), as consoantes do contexto segmental são idênticas e, em (70), são semelhantes, visto que a única diferença entre elas é [vozeamento]; em ambos os casos, os contextos permitem a aplicação de haplologia.

A literatura sobre haplologia é mais abundante e trata de diferentes aspectos do contexto de aplicação. Por isso, nas subseções a seguir, apresento as análises sobre este processo, de acordo com os seguintes níveis fonológicos: o contexto segmental, em 3.2.1; a estrutura silábica, na subseção 3.2.2; a estrutura prosódica, em 3.2.3; e a estrutura métrica em 3.2.4. Em 3.3, apresento a análise de Leal (2006), em que se unificam os dois processos. Finalmente, em 3.4, há uma discussão sobre a natureza da queda de sílaba, se é de coalescência ou apagamento.

\subsubsection{Contexto segmental}

Como dito na subseção anterior, diferentemente da elisão silábica, a haplologia é um processo fonológico muito estudado na literatura (cf. referências a seguir), cuja regra é formalizada do seguinte modo por Alkmim \& Gomes (1982: 51):

(71) Regra de haplologia para Alkmim \& Gomes (1982: 51) ${ }^{37}$

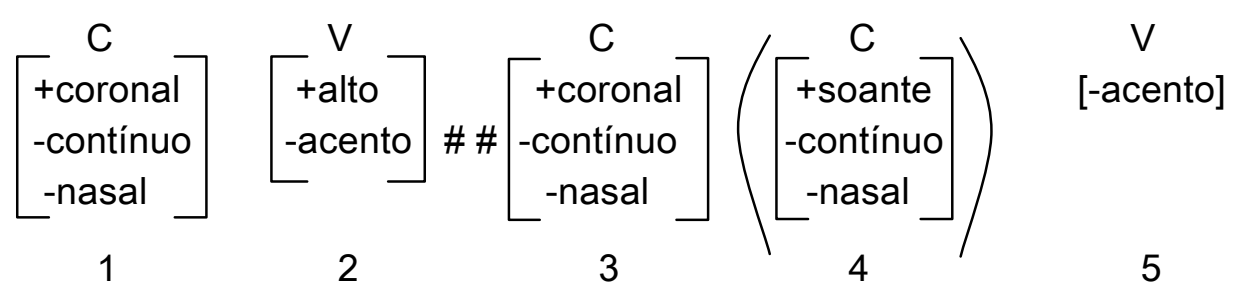

Segundo as autoras, a regra em (71) representa que pode haver aplicação de haplologia, num contexto de sândi externo (as fronteiras de palavra estão marcadas por “\#”), se a primeira sílaba for uma CV e a segunda pode ser tanto CV quanto CCV (a

\footnotetext{
37 Apesar de os pontos de $\mathrm{C}$ não serem binários, de acordo com o modelo de geometria de traços (cf. Clements \& Hume 1995) que adotamos aqui, conservamos a notação de Alkmim \& Gomes (1982) como [+coronal].
} 
opcionalidade da segunda consoante está representada pelos parênteses em (71)), e a possibilidade de apagamento dos segmentos 1 e 2 deve seguir os seguintes critérios:

i. O segmento 1 (primeira consoante) é uma coronal [-contínuo, -nasal] (ou seja, é necessariamente /t/ ou /d/);

ii. O segmento 2 (primeira vogal) não deve ser acentuado e não deve ter o traço [+alto];

iii. O segmento 3 (segunda consoante) é uma coronal [-contínuo, -nasal] (novamente, somente pode ser/t/ ou /d/);

iv. O segmento 4 (segunda consoante de ataque ramificado) é uma soante [-contínuo, -nasal], que pode aparecer ou não; e

v. O segmento 5 (segunda vogal) não deve ser acentuado e seus traços internos não importam.

Alkmim \& Gomes (1982: 48) afirmam que, mesmo que as consoantes possuam um mesmo ponto de articulação na forma subjacente, se forem diferentes de $/ \mathrm{t} / \mathrm{e} / \mathrm{d} /$, o processo fonológico é outro: há elisão vocálica, acarretando a adjacência de duas consoantes iguais, que ficam alongadas no output.

(72) saBE BEljar > *sa(BE) BEljar, mas sim: saB(E) BEljar ['sab:ej'za]

Em (72), a vogal /e/ é elidida, duas consoantes /b/ se tornam adjacentes, o que acarreta o alongamento destes segmentos, segundo Alkmim \& Gomes (1982), e continuam a ser produzidos distintamente como [b:]. No entanto, as autoras não apresentam espectrogramas em sua análise que mostrem este alongamento.

Para corroborar a ideia de que há apenas apagamento da vogal, e não haplologia, Alkmim \& Gomes (1982: 50) apresentam o seguinte par mínimo:

(73) A Fale limitou > [a.fa.l:i.mi.tow]

(74) A Fale imitou > [a.fa.li.mi.tow] 
Segundo as autoras, não há possibilidade de queda de sílaba em (73), já que o resultado é a produção de dois /I/, que continuam sendo pronunciados distintamente [l:]. Esta produção distinta das consoantes [l:] pode ser percebida com a comparação de (73) com (74), já que, neste último exemplo, há apenas um [l] na produção. Assim, para Alkmim \& Gomes (1982), só há possibilidade de haplologia com as consoantes /t/ e /d/; para as outras consoantes, o processo aplicado só pode ser a elisão vocálica, e as duas consoantes, em consequência do apagamento da vogal, ficam geminadas e são pronunciadas distintamente - um segmento alongado.

Bisol (2000), Battisti (2004) e Tenani $(2002,2006)$ concordam que, de fato, há a geminação consonantal. Seguindo a proposta de Sá Nogueira (1958), as autoras apontam que há duas etapas na haplologia: na primeira, há elisão da vogal; na segunda etapa, por estarem adjacentes, as consoantes podem geminar ou não. ${ }^{38}$

A diferença entre as duas propostas (a primeira em Bisol 2000, Tenani 2002 e Battisti 2004, seguindo Sá Nogueira 1958) é que, para Alkmim \& Gomes (1982), se houver duas consoantes iguais no resultado do apagamento vocálico, não há haplologia, já que as duas consoantes continuam a ser produzidas; por outro lado, para Bisol (2000), Battisti (2004) e Tenani (2002, 2006), a haplologia decorre de dois processos fonológicos: primeiramente, há elisão da vogal, e as consoantes adjacentes podem continuar a ser produzidas - desta vez, com degeminação destes segmentos.

Tenani (2003: 284, 304) explica que não trabalha com contextos segmentais que possam bloquear a haplologia, e assume aqueles que favorecem o processo (/t/ e /d/, como apontado por Alkmim \& Gomes 1982), já que a finalidade da autora é estudar a relação entre haplologia e constituintes prosódicos (cf. subseção 3.2.3). Da mesma forma, a variável dependente no trabalho de Battisti (2004) é a haplologia com as consoantes /t/ e $/ d /$, com o finalidade de verificar qual é a natureza do processo fonológico, se de apagamento ou de coalescência. Assim, as duas autoras não discutem contextos segmentais diferentes de /t/ e /d/.

Bisol (2000) também não trata de contextos segmentais, já que o intuito do artigo é verificar a relação entre ritmo e processos fonológicos, mas a autora apresenta o seguinte 
exemplo de haplologia (Bisol 2000: 409):

(75) O macaCO COmeu todas as bananas > maca(CO) COmeu

Como vemos em (75), há a possibilidade de queda de sílaba com o contexto segmental /ko + ko/ para Bisol (2000), ou seja, um contexto diferente da definição de Alkmim \& Gomes (1982) - diferente de /t/ e /d/.

Pavezi (2006a), trabalhando com os dialetos da cidade de São Paulo (NURC-SP) e de São José do Rio Preto (IBORUNA-SJRP), e Leal (2006), com o de Capivari, expandem o inventário de Alkmim \& Gomes (1982) com relação às consoantes que podem sofrer haplologia (e elisão silábica, segundo Leal 2006). ${ }^{39}$

A tabela a seguir apresenta os resultados dos dados de fala espontânea de Pavezi (2006a: 25):

Tabela 2 - Aplicações de haplologia com relação às consoantes (Pavezi 2006a: 25) - fala espontânea

\begin{tabular}{|c|c|c|}
\hline consoantes & total & $\% \mathrm{apl}$ \\
\hline obstruintes não contínuas & 1552 & 93 \\
\hline nasais & 82 & 5 \\
\hline fricativas & 33 & 2 \\
\hline total & 1667 & 100 \\
\hline
\end{tabular}

Os resultados da autora apontam que: i) as consoantes [-contínuo] representam 93\% de aplicação do processo; ii) as nasais tiveram 5\%; e iii) as consoantes [+contínuo] resultaram em $2 \%$ do total de aplicações. Como podemos observar na Tabela 2, a autora faz distinções das consoantes pelo seu modo de articulação, sem tratar das consoantes separadamente. Já no corpus experimental, Pavezi (2006a) analisa as sílabas (consoantes e vogais unidas) ${ }^{40}$ e, a partir dos resultados apresentados (Quadro 3.1 em Pavezi 2006a:

39 Os resultados de Leal (2006) estão reportados na subseção 3.3.

40 Pavezi (2006a: 114) classifica as consoantes do seguinte modo: (i) obstruintes: [labial] /p/ e /b, [-contínuo, +distribuído] [t J] e [dz] e [dorsal] /k/ e /g/; (ii) nasais: [labial] /m/ e [coronal] /n/; (iii) fricativas: [+contínuo, labial] /f/ e /v/, [+contínuo, coronal, +anterior] /s/ e /z/, [+contínuo, coronal, -anterior] /// e /z/; (iv) vibrantes: [+vozeado, -contínua, -distribuído] /r/; e (v) lateral: [+sonoro, +contínua, coronal] /l/. Quanto às vogais, são classificadas em [+baixo] /a/ e [+alto] /i/ e /u/. 
115) podemos verificar que:

(i) coronais [-contínuo] variaram de $70 \%$ a $80 \%$ na aplicação de haplologia (contextos $/ \mathrm{tu}+\mathrm{tu} /, / \mathrm{t} f \mathrm{i}+\mathrm{t} \mathrm{f} / \mathrm{/} / \mathrm{da}+\mathrm{da} /, / \mathrm{du}+\mathrm{du} / \mathrm{e} / \mathrm{d} z \mathrm{i}+\mathrm{d} z \mathrm{i} / ;$; e apenas $25 \%$ para o contexto /ta + ta/;

(ii) coronal [+contínuo] teve uma variação de aplicação do processo de $65 \%$ a $90 \%$, e os contextos /zu + zu/ e /lu + lu/ tiveram, respectivamente, só $25 \%$ e $30 \%$ de aplicação;

(iii) para as labiais [-contínuo], a taxa de aplicação é um pouco mais baixa (de $20 \%$ a $60 \%$ ), e o contexto que menos variou foi /pa + pa/, com $15 \%$;

(iv) as labiais [+contínuo] tiveram de $35 \%$ a $60 \%$ de aplicação, e o contexto /fu $+\mathrm{fu} /$ teve apenas $5 \%$;

(v) as dorsais [-contínuo] variaram na aplicação entre $40 \%$ e $80 \%$, e as taxas mais baixas são para os contextos /ga $+\mathrm{ga} / \mathrm{e} / \mathrm{ku}+\mathrm{ku} /(40 \%$ e $45 \%$, respectivamente);

(vi) com relação às nasais (todas [-contínuo]), a taxa de aplicação variou de $45 \%$ a $60 \%$, e o contexto /ma + ma/ teve apenas $20 \%$ de aplicação; e

(vii) para contextos com os fonemas /r/ (o /r/ forte, como em carro), as taxas de aplicação de haplologia variaram de $85 \%$ a $55 \%$.

A autora conclui que pode haver aplicação de haplologia com contextos segmentais diferentes daqueles apresentados por Alkmim \& Gomes (1982).

Com relação às vogais, Alkmim \& Gomes (1982: 50) afirmam que somente há haplologia se a primeira vogal do contexto segmental possuir o traço [+alto] (cf. regra apresentada em (71)). Assim, no exemplo abaixo, a aplicação de haplologia é agramatical para as autoras (p. 50):

(76) comiDA DO Líbano > *comi(DA) DO Líbano

Alkmim \& Gomes (1982) não discutem qual processo fonológico pode ocorrer em (76), mas afirmam que há bloqueio de haplologia. Para Pavezi (2006a), no entanto, a 
haplologia pode ocorrer tanto com vogais altas /i/ e /u/, como também com vogais baixas /a/, com base no mesmo teste aplicado a universitários de São José do Rio Preto.

Com relação ao nível em que o processo pode ser aplicado, podemos verificar que, ao longo dos trabalhos de Tenani (2002) e Pavezi (2006a), os segmentos vocálicos favoráveis à haplologia são /i/ e /u/, ou seja, as autoras utilizam barras para designar os segmentos, o que indicaria que são fonemas. Por outro lado, Alkmim \& Gomes (1982) descrevem os segmentos do contexto de haplologia entre colchetes "[ ]", indicando que a definição do processo está no nível fonético (cf. a regra para a haplologia de Alkmim \& Gomes (1982: 51), e sua reescrita em (71), apresentada na subseção 3.2.1). Ainda, Alkmim \& Gomes (1982: 48) definem a haplologia como:

(...) a supressão da sílaba final de uma palavra quando seguida por outra foneticamente semelhante. (grifos meus)

Observe os exemplos abaixo de Alkmim \& Gomes (1982: 48) (cf. (77) e (78)), de Tenani (2002: 105) (ver (79)) e de Pavezi (2006a: 116) (cf. exemplo (80)):

$\begin{array}{llll}(77)[i+i] & \text { limiTE DE palavra } & > & \text { limi(TE) DE palavra } \\ (78)[u+i] & \text { calDO DE cana } & > & \text { cal(DO) DE cana } \\ (79) / i+i / & \text { faculdaDE DInâmica } & > & \text { faculda(DE) DInâmica } \\ (80) / \mathrm{u}+\mathrm{u} / & \text { boniTO TUbarão }> & \text { boni(TO) TUbarão }\end{array}$

Em (77) e (78), Alkmim \& Gomes (1982) representam as vogais com o traço [+alto], no nível fonético; nos exemplos (79) de Tenani (2002) e (80) de Pavezi (2006a), as vogais são subjacentes.

Assim, é necessário uma discussão com relação a que nível deve ser levado em conta para o apagamento de sílaba, se o fonológico ou o fonético. Um indício de que é no nível fonológico (e não no fonético) que a regra de queda de sílaba se aplica pode ser encontrado no corpus desta tese, se levarmos em conta a diferença de processos de alçamento das vogais em final de palavra. Em Campinas, esta regra se aplica, ao contrário 
de Capivari, como exemplificamos abaixo com a palavra caldo:

(81) Capivari, sem alçamento:

['kaw.do]

(82) Campinas, com alçamento:

['kaw.dv]

Em ambas as cidades, apesar de haver uma redução na vogal final, notamos que as qualidades das vogais em final de palavra são diferentes em Capivari e Campinas. E pode haver aplicação de queda de sílaba tanto em dialetos sem o alçamento (o capivariano) quanto em dialetos com alçamento (o campineiro) - há variação de queda de sílaba em ambas as cidades.

Um outro argumento para interpretarmos que a queda de sílaba ocorre no nível fonológico, e não no fonético, é o emprego da teoria que embasa a análise do contexto segmental: trabalhamos com a geometria de traços, pois é a partir dos traços internos da cavidade oral (ponto de C e contínuo) dos segmentos que se define o processo (fonologicamente).

Assim, as vogais do contexto de queda de sílaba dos exemplos (77)-(80) são escritas a seguir, com base na geometria de traços, como tendo fonologicamente os traços de ponto de $\mathrm{C}$, da seguinte forma:
(83) $/ \mathrm{e}+\mathrm{e} / \mathrm{\text {[coronal }}+$ coronal]
$\operatorname{limi}(T E)$ DE palavra
(84) /o + e/: [dorso-labial + coronal]
cal(DO) DE cana
(85) $/ \mathrm{e}+\mathrm{i} /:$ [coronal + coronal]
faculda(DE) DInâmica
(86) /o + u/: [dorso-labial + dorso-labial]
boni(TO) TUbarão

Adicionalmente, vogais [+baixo] são tratadas como apresento abaixo (cf. exemplo de Leal 2006: 141), em que a implementação da regra é gramatical:

(87) $/ \mathrm{a}+\mathrm{a} / \mathrm{:}$ [dorsal + dorsal] não adian(TA), TÁ feito

(ALES)

Portanto, como pudemos observar nesta subseção, a regra de haplologia e, em 
termos gerais, de queda de sílaba, pode comportar todos os segmentos consonantais e vocálicos, assim como explicam Pavezi (2006a) e Leal (2006) (sobre este trabalho, cf. a subseção 3.3).

\subsubsection{Estrutura silábica}

Com relação à estrutura silábica, vimos que a sílaba elidida deve ser $\mathrm{CV}$, segundo a análise de Alkmim \& Gomes (1982).

Para explicar a relação entre acento e estrutura silábica, Collischonn (2007) analisa processos fonológicos de sândi interno e externo e, dentre estes, a haplologia. De acordo com a autora (pp. 221-2), a estrutura silábica não interfere neste processo fonológico, já que:

(...) as sílabas afetadas são originalmente bem-formadas. (...) O que desencadeia a haplologia não é nem uma nem outra [estrutura silábica e acento], mas uma exigência sobre propriedades da estrutura segmental, o OCP.

Collischonn (2007) defende que a haplologia está relacionada ao OCP, primeiramente proposto por Leben (1973) em estudos de línguas tonais, e muitos outros autores trabalham com o princípio (cf. McCarthy 1979, Goldsmith 1990). McCarthy (1988: 88) reformulou-o do seguinte modo: ${ }^{41}$

Adjacent identical elements are probibited.

Assim, para Collischonn (2007), se houver elementos adjacentes idênticos numa sequência segmental, a haplologia é implementada; a autora sustenta que a estrutura silábica não é um fator importante na queda de sílaba, pois as estruturas originais já são bem formadas. Contudo, Battisti (2004), Pavezi (2006a) e Leal (2006) encontraram casos em que a sílaba sujeita ao apagamento não é uma CV, mas sim CCV. O exemplo a seguir é de Battisti (2004):

\footnotetext{
41 McCarthy (1986: 208) define o OCP de um modo mais restrito: "At the melodic level, adjacent identical elements are prohibited."
} 
(88) Den(TRO) DO consultório.

Em (88), a sílaba elidida tem ataque ramificado, em que a consoante / $r /$ preenche a segunda posição do ataque e, mesmo assim, a haplologia é gramatical.

Os exemplos abaixo também ilustram contextos em que as sílabas sujeitas à queda têm estruturas diferentes - sílaba leve em (89) e (92), sílaba com ataque ramificado em (90) e (93), e sílaba pesada em (91) e (94):

(89) o cenTO DA banana é caro > o cen(TO) DA banana é caro

(90) o cenTRO DA cidade é bonito > o cen(TRO) DA cidade é bonito

(91) a general moTORS DO brasil > a general mo(TORS) DO brasil

(92) o denTE DO juízo > o den(TE) DO juízo

(93) o venTRE DA terra > o ven(TRE) DA terra

(94) o shopping cenTER DE Campinas > o shopping cen(TER) DE Campinas

Assim, a queda de sílaba não é bloqueada em (89)-(94); em outras palavras, a sílaba sujeita ao processo não precisa ser necessariamente uma estrutura CV. ${ }^{42}$

\subsubsection{Métrica}

A maior parte dos trabalhos sobre haplologia e métrica discutem se o acento das sílabas do contexto pode influenciar o processo; poucos são os trabalhos que observam se a aplicação do processo pode ter consequências rítmicas.

\footnotetext{
42 As sílabas sujeitas ao apagamento, por exemplo, /tre/ de ventre (em (93)) e /ter/ de center (cf. (94)) não têm uma estrutura simples CV, mas sim CCV e CVC, respectivamente. Poderíamos seguir o raciocínio de que as sílabas /tre/ e /ter/ possam se realizar com a queda de /r/, já que esse tipo de processo fonológico é comum em palavras como dentro, que também pode ser produzido para den[tv], centro > cen[tv]; outro > ou[tv]. Da mesma forma, sílabas CVC podem ser simplificadas para CV, como em revólver > revólve; açúcar > açúca; hambúrguer > hambúrgue. Haveria, talvez, duas causas (dentre outras) para a simplificação silábica: (i) taxa de elocução (contextos em que as palavras tenderiam a uma maior simplificação); e (ii) difusão lexical (de acordo com Cristófaro (2001), os difusionistas "sugerem que uma mudança sonora é aplicada a algumas palavras e pode atingir (ou não) o léxico como um todo. Portanto, é a palavra que muda em relação a sons específicos." (cf. também cf. nota 36). Não tratamos do tema nesta tese, e análises futuras podem elucidar a questão. Agradeço ao Prof. Dr. Emilio Gozze Pagotto e Prof $^{\mathrm{a}}$ Dr $^{\mathrm{a}}$ Luciani Tenani por me chamarem a atenção a estas possibilidades de análise.
} 
Especificamente com relação ao acento da primeira sílaba do contexto de haplologia, Alkmim \& Gomes (1982), Bisol (2000), Pavezi (2006a) e Tenani (2002, 2003, 2006) concordam que só é possível a aplicação de haplologia se a sílaba sujeita à queda for fraca - sílaba com acento bloqueia o processo (cf. Alkmim \& Gomes 1982, Tenani 2002: 141 e subseção 1.3).

De acordo com Alkmim \& Gomes (1982), a segunda sílaba do contexto também deve ser fraca, como vimos na regra apresentada em (71). Observe o exemplo abaixo, adaptado de Alkmim \& Gomes (1982: 50):

(95) gaTO TONto > *ga(TO) TONto

De acordo com as autoras, não há queda de sílaba em (95) porque a segunda sílaba do contexto segmental ton é forte, o que impede a aplicação do processo. A fim de verificar se contextos em que a segunda sílaba é forte podem causar o bloqueio do processo, Tenani (2002) testa os acentos das sílabas do contexto de haplologia, controlando o contexto segmental, a prosódia (fronteira de frases fonológicas) e a estrutura rítmica, como exemplifico a seguir:

Tabela 3 - Haplologia e tonicidade, adaptado de Tenani (2002: 141)

\begin{tabular}{|l|c|c|}
\hline \multicolumn{1}{|c|}{ sentença } & estrutura rítmica & $\%$ de haplologia \\
\hline (a) a autoridaDE Dltou regras à polícia & $' \sigma \sigma \# \sigma^{\prime} \sigma$ & 50 \\
\hline (b) a autoridaDE Dlta regras à polícia & $' \sigma \sigma \# \sigma^{\prime} \sigma \sigma$ & 50 \\
\hline (c) o diDI DItou regras à polícia & $\sigma{ }^{\prime} \sigma \# \sigma^{\prime} \sigma$ & 0 \\
\hline
\end{tabular}

No teste de Tenani, houve bloqueio de haplologia somente se a primeira sílaba do contexto segmental for forte - cf. exemplo (c) na Tabela 3. Estes resultados são os mesmos de Alkmim \& Gomes (1982), Pavezi (2006a) e Leal (2006). Tenani (2002: 141) continua:

Como o contexto segmental e a estrutura prosódica são exatamente iguais aos contextos em que as sílabas são ambas átonas ou somente a segunda acentuada, conclui-se que o bloqueio encontrado é motivado pela tonicidade da primeira sílaba do contexto de sândi. 
Assim, pode-se concluir que uma exigência acentual da aplicação do processo é que a primeira sílaba deve ser fraca.

\subsubsection{Prosódia}

Há três trabalhos que relacionam a haplologia com a estrutura prosódica.

O primeiro deles é Tenani (2002), que examinou os contextos segmentais de haplologia dentro frase fonológica (ou seja, entre dois grupos clíticos), entre frases fonológicas, entre frases entonacionais e entre enunciados. Tenani explica que a aplicação do processo está inversamente relacionada aos constituintes mais altos da hierarquia, isto é, quanto mais alto for o constituinte, menor é a aplicação de haplologia.

Outro trabalho é o de Battisti (2004), que analisa, com base na sociolinguística variacionista, a posição do contexto segmental na frase fonológica. A autora explica que o contexto que mais favoreceu a haplologia foi o de vogais iguais, dentro de frase fonológica, como exemplifico a seguir:

(96) vonta(DE) DE conhecer

Os níveis estudados por Pavezi (2006a) são os mesmos que Tenani (2002) (dentro frase fonológica, entre frases fonológicas, entre frases entonacionais e entre enunciados); no entanto, os resultados encontrados pelas autoras foram diferentes: dentro de frases fonológicas e entre frases fonológicas são os níveis mais propícios à haplologia, segundo Pavezi (2006a). Apresento abaixo a tabela de comparação entre os resultados de Tenani (2002) e Pavezi (2006a) (adaptada de Pavezi 2006a: 52):

Tabela 4 - Haplologia e domínios prosódicos - dados adaptados de Pavezi (2006a: 52)

\begin{tabular}{|c|c|c|c|c|c|c|}
\hline & \multicolumn{3}{|c|}{ Tenani (2002) (dados experimentais) } & \multicolumn{3}{|c|}{ Pavezi (2006a) (fala espontânea) } \\
\hline estrutura prosódica & tokens & aplicação & $\%$ & tokens & aplicação & $\%$ \\
\hline entre Фs e mesmo $\Phi$ & 24 & 22 & 92 & 51 & 25 & 49 \\
\hline entre Is e mesmo I & 12 & 8 & 66 & 1 & 0 & 0 \\
\hline enunciado & 30 & 17 & 56 & 0 & 0 & 0 \\
\hline total & 66 & 47 & & 52 & 25 & \\
\hline
\end{tabular}

Pavezi (2006a) explica que, ao comparar resultados de fala espontânea e dados 
experimentais, o único constituinte que pôde de fato ser comparado foi a frase fonológica, pois para frase entonacional houve apenas um dado, e nenhum token para enunciado. A autora conclui que contextos de haplologia na frase fonológica são os mais frequentes, com variação na aplicação do processo.

De forma resumida, vimos nesta subseção que o nível mais favorável para aplicação de haplologia é a frase fonológica, de acordo com Battisti (2004) e Pavezi (2006a) - para dados de fala espontânea. Tenani (2003) argumenta que quanto mais alto for o nível prosódico, menor é a implementação da haplologia.

\subsection{A análise de Leal (2006): unindo os dois processos}

Nesta subseção, apresento os resultados de queda de sílaba (elisão silábica e haplologia) encontrados em Leal (2006), unificando nesta análise os dados apresentados nas subseções anteriores.

O principal objetivo de Leal (2006) foi verificar se a elisão silábica e a haplologia são um mesmo processo fonológico ou se são duas regras distintas, com base em três níveis fonológicos: segmental, prosódico e métrico. O corpus desse trabalho é composto de duas partes: na primeira (experimental), foram aplicados testes contendo sintagmas nominais (substantivo seguido de adjetivo), controlando-se o ponto de C, o traço [contínuo] (cf. Clements \& Hume 1995) e o vozeamento dos segmentos. A gramaticalidade da queda de sílaba nos sintagmas foi julgada de acordo com a intuição da pesquisadora e da informante capivariana FC, de 31 anos. A segunda parte do corpus é naturalística, formada por duas seções de trinta minutos cada uma (falas espontâneas), com dois informantes capivarianos de 28 anos, um deles com estudo até o ensino fundamental (ALES) e o outro estudou até o ensino médio (BGN).

Para o contexto segmental, os resultados do teste e da análise naturalística apontam que, na elisão silábica e na haplologia, deve haver consoantes que tenham os mesmos traços abaixo da cavidade oral, ou seja, os pontos de C e o valor para [contínuo] devem ser os mesmos. Observe os seguintes exemplos (de Leal 2006): 
(97) $/ \mathrm{t}+\mathrm{d} / \quad$...um mon(TE) DE técnica pra cantar.

$(B G N)$

(98) $\quad / d+d / \quad$...tenho vonta(DE) DE matar.

(ALES)

(99) $\quad / d+t / \quad \operatorname{var}(\mathrm{DO})$ TInha contado

(100) /k+k/ um mole(QUE) COM outra

(ALES)

Em (97), o contexto consonantal é composto de duas coronais [-contínuo], e a única diferença entre elas é que a primeira é [-vozeado] e a segunda é [+vozeado]. No contexto em (98), há duas sílabas idênticas com consoantes coronais [-contínuo]. Em (99), também há apenas uma diferença entre as consoantes: /d/ é [+vozeado] e /t/ é [-vozeado], ambas coronais [-contínuo]. O exemplo (100), / k+k/ é composto de duas consoantes com os traços dorsais [-contínuo]. ${ }^{43}$ Uma vez que os ambientes nestes exemplos têm consoantes com diferenças, no máximo, em vozeamento, caracterizam casos de haplologia.

Nos exemplos a seguir, as consoantes do contexto segmental são diferentes em mais traços do que apenas [vozeamento]:

$\begin{array}{lllll}(101) & / \mathrm{b}+\mathrm{m} / & \text { goia(BA) MAdura } & >\text { [go'ia.ma]dura } & \text { (teste) } \\ (102) & / \mathrm{z}+\mathrm{J} / & \text { babo(SA) CHElrosa } & >\text { ba['bofe]rosa } & \text { (teste) } \\ (103) & / \mathrm{s}+\mathrm{d} / & { }^{*} \text { crian(ÇA) DInamarquesa } & >\text { *crian[di]namarquesa } & \text { (teste) } \\ (104) & / \mathrm{b}+\mathrm{d} / & { }^{*} \text { goia(BA) DOcinha } & >{ }^{*} \text { [go'jado]cinha } & \text { (teste) }\end{array}$

No contexto segmental /b+m/ em (101), as duas labiais [+vozeado, -contínuo], que diferem quanto ao traço [nasal]: a primeira é uma consoante oral e a segunda é uma nasal. Em (102), o contexto /z+J/ é formado por duas coronais [+contínuo]; a primeira consoante é [+anterior, -distribuído] e a segunda é [-anterior, +distribuído]. Em (103), /s+d/ é formado por duas consoantes que têm em comum o ponto de $C$ [coronal] e os traços [+anterior, -distribuído]; mas, além da distinção em [vozeamento] (/s/ é [-vozeado] e /d/ é [+vozeado]), as consoantes são diferentes em [contínuo]: a primeira é [+contínuo] e a segunda é [-contínuo]. Finalmente, no contexto $/ \mathrm{b}+\mathrm{d} / \mathrm{em}(104)$, há duas consoantes [+vozeado, -contínuo] que diferem no ponto de C: /b/ é uma [labial] e /d/ é uma [coronal, +anterior,

${ }^{43}$ Cf. exemplo apresentado em (75), de Bisol (2000), com um mesmo contexto /k + k/. 
-distribuído]. Em (103), /s+d/ são diferentes em [contínuo] e, em (104), /b+d/ têm pontos de C distintos; a aplicação de haplologia e de elisão silábica, respectivamente, em ambos os casos, é agramatical.

Nos exemplos de haplologia e de elisão silábica, podemos observar que os dois processos são regidos pelas mesmas regras: se as consoantes tiverem pontos de $\mathrm{C}$ iguais e valores para [contínuo] idênticos (cf. exemplos de haplologia de (97)-(100) e de elisão silábica em (102) e (101)), o processo pode ser implementado. Por outro lado, consoantes com [contínuo] (cf. contexto /s+d/ no exemplo (103)) ou pontos de C diferentes (cf. contexto $/ b+d /$ em (104)), o processo é bloqueado. Além disso, notamos que [vozeamento] não bloqueia o processo, pois as consoantes podem ser iguais neste traço (cf. contextos de haplologia $/ \mathrm{d}+\mathrm{d} /, / \mathrm{k}+\mathrm{k} /$ e $/ \mathrm{b}+\mathrm{m} /$ de elisão silábica) ou diferentes $(/ \mathrm{t}+\mathrm{d} /, / d+\mathrm{t} /$ que são contextos de haplologia e $/ z+\int /$ de elisão silábica). Finalmente, podemos observar que a diferença em [anterior, distribuído] não bloqueia o processo, como se vê no contexto $/ z+\int /$.

Assim, no que concerne ao contexto segmental, de acordo com a análise consonantal realizada, Leal (2006) explica que a elisão silábica e a haplologia são um mesmo processo fonológico, que obedece à seguinte regra (p. 165):

A queda de sílaba se dá se as consoantes envolvidas no processo tiverem o mesmo ponto de $\mathrm{C}$ e o mesmo valor para o traço [contínuo].

Com relação às vogais, Leal (2006) aponta que a qualidade não influencia na aplicação da queda de sílaba: as combinações vocálicas podem variar em anterioridade ou altura, com gramaticalidade da sentença (cf. de Lacy 1999, Bisol 2000, Pavezi 2006a e Sasaki 2008) - diferente do que afirmam Alkmim \& Gomes (1982). Observe os exemplos a seguir, do corpus naturalístico de Leal (2006):

$\begin{array}{lll}\text { (105) } & / \mathrm{a}+\mathrm{a} / \mathrm{cabe}(\mathrm{C} A) \text { SAUdável } & \text { (teste) } \\ \text { (106) } & / \mathrm{a}+\mathrm{e} / \mathrm{estra}(\mathrm{DA}) \mathrm{DE} \text { terra } & \text { (BGN) }\end{array}$

O contexto (105) é de haplologia, pois há duas consoantes iguais /s + s/; quanto às 
vogais, também são iguais, la + a/. No exemplo (106), no que diz respeito às consoantes, é novamente um ambiente para haplologia (coronais $/ d+d /$ com mesmo traço [+vozeado]). No entanto, o contexto la + e/, em que a primeira vogal é [dorsal] (ou [+baixa], nos termos de Alkmin \& Gomes 1982), seguida de uma coronal eliminaria este tipo de contexto como possibilidade de haplologia, segundo as autoras, já que a primeira vogal é uma dorsal. Como se pode notar, a queda da sílaba é possível. Assim, além de vogais [coronal] /e, i/ e [dorso-labial] /o, u/ (segmentos com o traço [+alto], segundo a fonologia tradicional), a queda de sílaba é permitida também em contextos vocálicos com [dorsal] na primeira sílaba. O mesmo ocorre com os contextos referidos por Leal (2006) como ambientes de elisão silábica, isto é, casos em que as consoantes partilham o mesmo ponto de $\mathrm{C}$ e contínuo, diferente de [coronal], também permitem a queda de sílaba quando a primeira vogal é [dorsal], como ilustram os exemplos abaixo:

$$
\begin{array}{lll}
(107) & / a+a / \text { namora(DA) NAriguda } & \text { (teste) } \\
\text { (108) } & / a+e / \text { cabe(ÇA) Glgante } & \text { (teste) }
\end{array}
$$

Em (107), há uma possibilidade de aplicação de elisão silábica, pois o contexto consonantal é de duas coronais [-contínuo], diferentes em [nasal] (é uma oral seguida de uma nasal); quanto às vogais, são duas dorsais idênticas. No exemplo (108), há um contexto consonantal $/ s+3 /$ de elisão silábica, já que as consoantes são coronais [+contínuo], que diferem nos traços que estão abaixo do nó coronal: a primeira é uma consoante [+anterior, -distribuído] e a segunda é [-anterior, +distribuído]. Com relação às vogais, há uma dorsal seguida de uma coronal - contexto la + e/. Comparando-se os contextos vocálicos nos exemplos de (105)-(108), podemos notar que, tanto para a haplologia (cf. (105) e (106)) quanto para a elisão silábica (ver (107) e (108)), não há bloqueio dos processos se houver na primeira sílaba uma vogal dorsal - tanto para vogais iguais /a + a/ (cf. haplologia em (105) e elisão silábica em (107)) ou diferentes /a + e/ (ver. haplologia em (106) e elisão silábica em (108)). Em outras palavras, se a vogal da sílaba sujeita à queda for uma dorsal, a elisão silábica e a haplologia podem ocorrer.

Leal (2006) não controlou a estrutura das sílabas sujeitas à elisão silábica e 
haplologia. No entanto, houve aplicação de haplologia com sílabas CCV, o que corrobora Battisti (2004) e Pavezi (2006a), como exemplificado a seguir:

$\begin{array}{lll}(109) & \text { den(TRO) DA delegacia } & \text { (ALES) } \\ (110) & \text { den(TRO) DO esgoto } & \text { (ALES) } \\ (111) & \text { vi(DRO) DA frente } & \text { (ALES) }\end{array}$

Para a elisão silábica, houve um caso de aplicação em que a sílaba sujeita ao processo é uma CVC: ...os caras senta(DOS) NUM canto (ALES) $)^{44}$

Até o momento, verificamos que a elisão silábica e a haplologia são um mesmo processo fonológico no que concerne ao contexto segmental (consoantes e vogais). Mesmo não tendo controlado a estrutura silábica, notamos que pode haver casos de aplicação de elisão silábica e haplologia com sílabas diferentes de CV nos dados de Leal (2006), o que vai de encontro aos resultados de Alkmim \& Gomes (1982).

Corroborando Tenani (2002, 2003), Battisti (2004) e Pavezi (2006a), Leal (2006) verifica que a haplologia pode ser aplicada em qualquer nível prosódico, como ilustram os exemplos a seguir:

(113) $\quad[\text { a gen(TE) }]_{\Phi}[\text { TOcou }]_{\phi}$ e Roni gravou $(B G N)$

(114) $\quad[\text { pendura(DO) }]_{\Phi}[\text { NO pau-de-arara }]_{\Phi}$ (ALES)

O contexto segmental em (113) é ambiente para haplologia, já que as consoantes

\footnotetext{
44 Chamamos a atenção para a possibilidade, neste exemplo (112), de o /s/ de sentados poder ser apagado antes da aplicação da queda de sílaba, pois é a $3^{a}$ marca de plural no sintagma nominal oS caraS sentadoS, que pode ser proferida como os cara sentado. Desse modo, haveria uma simplificação da sílaba de CVC /dos/ de sentadoS para uma estrutura CV /do/ sentado(S). A pergunta que se coloca é: como se dá a ordenação de regras nestes casos de apagamento, em que parece haver um efeito da morfologia na queda de sílaba? Esta é uma questão que foge do escopo deste trabalho, a ser estudada futuramente. Agradeço à Prof $^{a}$ Dr $^{a}$ Ester Mirian Scarpa por me chamar a atenção para este tema.
} 
são idênticas, e o processo ocorre entre duas frases fonológicas: [ a gente ] $e_{\phi}[$ tocou ] $\Phi$ não podem ser reestruturadas, pois tocou não é complemento de a gente. Em (114) /d + n/ é um contexto de elisão silábica, em que no pau-de-arara é complemento de pendurado, mas não há reestruturação porque a segunda frase fonológica é ramificada (há dois grupos clíticos [ no pau ]c e [ de-arara ]c que impossibilitam a reestruturação).

Para ambos os processos, o constituinte prosódico em que mais ocorreu a queda de sílaba é dentro de frase fonológica reestruturada, o que corrobora Battisti (2004) e Pavezi (2006a).

De tudo o que vimos podemos concluir que a elisão silábica e a haplologia são regidas também pelas mesmas características prosódicas.

Com relação à métrica, o maior número de aplicação de elisão silábica e de haplologia do corpus de Leal (2006) foi a sequência de [sílaba forte + sílaba fraca + sílaba forte], ou seja, numa sucessão de sílabas $[x \cdot \# \cdot x]$, com um resultado $[x \# \cdot x]$. Nestes casos, a tendência ao PAR é respeitada na aplicação de ambos os processos. Nos resultados de Leal (2006), observou-se também que há possibilidade de elisão silábica e de haplologia com um resultado de choque de acento, o que corrobora Tenani (2002) (para haplologia): uma sequência $[x(\bullet) \# x$ ] não bloqueia o processo - diferente da proposta de haplologia de Alkmim \& Gomes (1982).

Com base nas análises apresentadas nesta subseção, podemos afirmar que a elisão silábica e haplologia possuem as mesmas propriedades fonológicas, listadas a seguir:

i. Contexto segmental: não é necessariamente composto das consoantes /t/ e /d/ (especificamente para a haplologia, cf. Alkmim \& Gomes 1982), mas pode ocorrer ainda com outras consoantes (também para a haplologia, cf. Bisol 2000 e Pavezi 2006a), e estes segmentos devem ter, internamente, o mesmo ponto de C e o mesmo valor para o traço [contínuo] (Leal 2006, 2007). As vogais subjacentes do contexto podem ser, além daquelas propostas por Alkmim \& Gomes (1982) (quais sejam: /i/, /e/, /o/, /u/), também /a/ (cf. Pavezi 2006a e Leal 2006);

ii. Estrutura silábica: não está restrita a sílabas CV (Alkmim \& Gomes 1982), mas o apagamento pode ser aplicado também com sílabas CCV (Battisti 2004, Pavezi 
2006a, Leal 2006) ou CVC (Leal 2006);

iii. Hierarquia prosódica: não afeta a aplicação de queda de sílaba, uma vez que nenhum constituinte bloqueia o processo (Tenani 2002, 2003; Pavezi 2006a e Leal 2006) e o nível em que há um maior favorecimento do processo é o da frase fonológica (Tenani 2002, 2003; Battisti 2004, Pavezi 2006a e Leal 2006); e

iv. Nível métrico: a sílaba propensa ao apagamento deve ser fraca (Alkmim \& Gomes 1982; Tenani 2003, 2006; Bisol 2000, Pavezi 2006a e Leal 2006); Leal 2006 aponta também que o maior número de aplicações de queda está no contexto $[\mathrm{x} \cdot \# \cdot \mathrm{x}]$ que resulta em $[\mathrm{x} \# \cdot \mathrm{x}]$; por fim, a aplicação de queda de sílaba que resulte em choque acentual não bloqueia o processo.

Uma vez descritas as propriedades dos segmentos, das estruturas silábicas, prosódicas e métricas de queda de sílaba, com base na literatura, uma questão relevante é se a natureza da regra é de apagamento ou coalescência, questão tratada na subseção a seguir.

\subsection{Coalescência ou apagamento}

Uma questão importante sobre a queda de sílaba diz respeito à questão de qual sua natureza: o processo resulta de coalescência (fusão) ou apagamento?

A grande parte dos trabalhos defendem que a haplologia ${ }^{45}$ é um modo de se evitar material fonético/fonológico idêntico (cf. Plag 1998) e normalmente o desencadeador do processo é então algum tipo de restrição como o OCP (Plag 1998, Yip 1998, Tenani 2002, Battisti 2004, McBride 2004, Neeleman \& Koot 2005, Collischonn 2007). A definição de Stemberger (1981) a seguir é uma restrição mais específica do que McCarthy (1988: 88) (cf. 3.2.2), pois leva em conta também informações morfológicas:

\footnotetext{
45 Veja que aqui haplologia não está restrita a um tipo de segmento ou sílaba. Assim, observamos que, em conformidade com a proposta de Leal (2006), ele se aplica também aos casos de elisão silábica - cf. capítulo 3, seção 3.3 .
} 
(115) Stem-End Haplology (Stemberger 1981: 791):

[The absence of] an affix or clitic (...) when the adjacent part of the stem is homophonous to it.

Outro trabalho em que há uma versão mais restrita do OCP é Menn \& McWhinney (1984). Para os autores, há nas línguas uma restrição de morfes repetidos e que estejam adjacentes, mas esta restrição pode ser violada (p. 519).

Como se vê, estas restrições fazem menção a aspectos morfo-fonológicos. E de fato, os estudos costumam diferenciar dois tipos de haplologia: morfológica (ou sintática) ${ }^{46}$ e fonológica. De Lacy (1999), por exemplo, distingue a haplologia morfológica da fonológica: na primeira, há dois morfemas fonologicamente idênticos no nível subjacente que se coalescem no output. Em nota de rodapé (p. 51), o autor afirma que a haplologia fonológica é somente encontrada diacronicamente nas línguas e tem uma natureza de apagamento, mas esta supressão é idiossincrática:

Phonological haplology is basically a diachronic process (Hock 1991:109, Grammont 1933), and is the idiosyncratic deletion of similar sequences of morpheme-internal material. (grifo meu)

De Lacy (1999) apresenta os exemplos (116) e (117) abaixo, casos de haplologia morfológica e fonológica, respectivamente:

$$
\begin{aligned}
& \text { /analIZ/ + }\{\text {-ISt }\} \quad>\text { /analISt/ versus */analIZISt/ } \\
& \text { 'analisar' 'sufixo subst.' > analista (francês) } \\
& \text { (exemplo de Corbin \& Plénat 1992: 101) }
\end{aligned}
$$

*nuTRITRIx > nuTRIx

'enfermeira' (latim)

(exemplo de Hock 1991:109)

46 Há outros autores que consideram que a morfologia tem um papel importante na haplologia, em que morfemas homófonos (sufixos, raízes, morfes) se fundem (merge) no output - por isso, o processo é muitas vezes chamado de haplologia morfológica (Russel 1999; Stemberger 1981; Menn \& McWhinney 1984; Plag 1998; de Lacy 1999; Plag 1998). 
Em (116), os segmentos /iz/ e /is/ se fundem (nenhum segmento é apagado) em /is/, permanecendo propriedades morfológicas no output, de acordo com de Lacy (1999). Este exemplo é um dos casos chamados de identidade parcial, já que o traço [vozeamento] é diferente entre as consoantes. De Lacy (1999: 72) explica que este traço é irrelevante na haplologia, já que o processo pode ser implementado mesmo com uma diferença em [vozeamento].

A proposta de haplologia morfológica é similar à assimilação de traços na fonologia autossegmental: informações morfológicas não poderiam ser apagadas no output, caso contrário, estas informações se perderiam depois da aplicação do processo. O conteúdo morfológico se une ao elemento que permanece no output.

No caso da haplologia fonológica, tem-se o apagamento do conteúdo semelhante, como em (117), em que há duas sequências /TRI + TRI/. Mas, para de Lacy, a haplologia fonológica é idiossincrática, ou seja, não há uma regra de aplicação sempre que o contexto for encontrado.

Outros autores que consideram a haplologia como resultado de coalescência são Stemberger (1981), Menn \& McWhinney (1984), Plag (1998), Lawrence (1998) e Russel (1999).

O problema de se considerar a haplologia como coalescência ou fusão é que este processo indica a convergência de unidades linguísticas, originalmente separadas, que antes podiam ser distinguidas (Crystal 1985: 49, 123). Observe um exemplo de coalescência no português brasileiro:

(118) leu/ropa > [o]ropa

Em alguns dialetos, as vogais /eu/ podem se fundir, formando um único segmento [o] no output. Observe que, no resultado da fusão [o], há traços de ambos os segmentos subjacentes /e/ e /u/: 


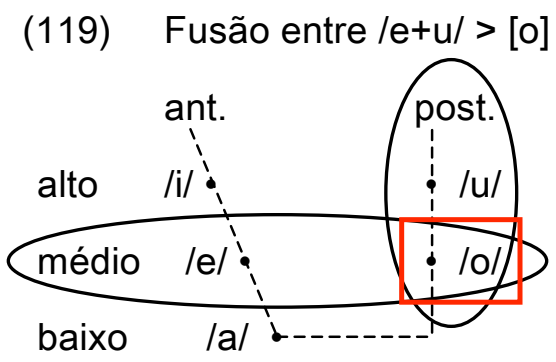
/e/: [anterior, médio]
/u/: [posterior, alto]
resulta em
[o]: [posterior, médio]

Como se nota em (119), a fusão entre os traços [anterior, médio] da vogal /e/ e [posterior, alto] da vogal /u/ resulta nos traços [posterior, médio] da vogal [o].

De Lacy (1999: 06-08) busca no japonês um exemplo de haplologia para ratificar a proposta do processo como coalescência de segmentos, como apresento a seguir:

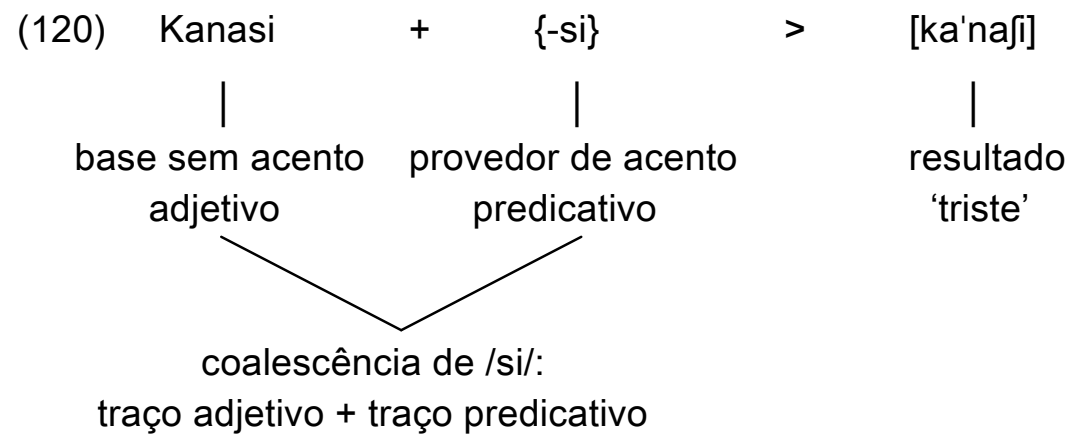

Como se observa em (120), no japonês, o adjetivo kanasi 'triste' não possui acento, mas, quando se junta ao predicativo $\{-$ si $\}$, este morfema atribui acento à sílaba imediatamente anterior a ele, em bases não acentuadas. Se fosse concebido como apagamento de afixo, o output não teria acento, formando *[kanafi]. O acento estaria correto em bases desacentuadas, como /kanasi/, mas errado em bases acentuadas - a acentuação por afixação de $\{$-si\} faz com que se acentue a penúltima vogal da raiz. Dessa forma, o afixo \{-si\} deve pertencer à raiz e, simultaneamente, ao sufixo da palavra. Então, o resultado [ka'nafi], com acento, explicaria a coalescência de traços morfológicos.

No entanto, como vimos no exemplo sobre coalescência do português, duas consoantes coronais /s/ [+anterior, -distribuído] não teriam por que se tornar /J/ [-anterior, +distribuído], como resultado de coalescência. Assim, entendemos que a união dos fonemas /s/ da raiz kanasi e /s/ do sufixo \{-si\} que se tornam [] em [ka'nafi] não podem ser 
explicados fonologicamente como fusão.

Além da questão acima, se haplologia como coalescência pode dar conta de casos em que os segmentos não são necessariamente idênticos, mas semelhantes - como na haplologia com /t/ e /d/ ou no caso do francês /analiZ/ + \{-iSt $\}>$ /analiSt/ versus */analiZiSt/, cf. exemplo anterior (116), de de Lacy (1999: 22), para quem o traço [vozeamento] não é relevante para o processo - a coalescência não dá conta de outros casos, como exemplificado a seguir (cf. exemplos de Battisti 2004, Pavezi 2006 e Leal 2006):

(121) den(TRO) DE ${ }^{47}$

Em (121), um resultado de coalescência entre as consoantes /tr/ e /d/ deveria levar em conta também os traços de $/ r /$, do ataque ramificado, o que não acontece.

A alternativa, então, é a análise de que o processo se dá por apagamento, independentemente de ser haplologia sintática ou fonológica. Neeleman \& Koot (2005) dão o seguinte exemplo em mandarim:

$\begin{array}{lllcc}\text { Bing dou } & \text { hua } & \text { LE } & (\text { LE) } \\ \text { gelo todo } & \text { derreter } & \text { perfectivo } & \text { mudança de estado }\end{array}$

'O gelo derreteu' (exemplo de Yip: 1998: 226)

Em (122), segundo os autores, há apagamento do segundo $\{$-le\}, indicativa de 'mudança de estado', uma vez que está adjacente ao perfectivo $\{-l e\}$.

Autores que assumem que a natureza da haplologia é por apagamento são Miller (1992), Ortmann \& Propescu (2000), Neeleman \& Koot (2005), Mercado (2001) e McBride (2004).

Para o português brasileiro, Battisti (2004) defende que este processo fonológico é de apagamento (resultante do OCP). Com base na teoria da otimalidade, a autora defende que, na hierarquia de haplologia, o OCP está abaixo de MAX, e conclui:

${ }^{47}$ Cf. nota 42. 
O desempate pela versão A [apagamento] de HS [haplologia sintática] para o PB [português brasileiro] vem da análise com OCP abaixo de MAX, conforme a Hierarquia Básica de de Lacy (1999). Por ela, só sequências idênticas de segmentos sofrem haplologia (por Co [coalescência]); sequências parcialmente idênticas como as que são passíveis de sofrer HS no PB não são possíveis.

No caso de haver apagamento, a questão que se coloca é qual sílaba deve ser apagada, a primeira ou a segunda. De acordo com Casali (1997), as línguas diferem quanto a apagamentos vocálicos em contextos $\mathrm{V}$ \# $\mathrm{V}$ : é mais comum o apagamento de $\mathrm{V} 1$ do que de V2. O autor estudou 85 línguas e, dentre elas, 55 apagam V1, e toda língua que apaga V2 apaga também V1 (com exceção de 2 línguas apenas - cf. Casali 1997: 496).

Para Miller (1992) e Ortmann \& Popescu (2000), por exemplo, há apagamento do primeiro ou segundo morfema, a depender de características morfológicas.

Há inclusive análises que propõem um apagamento de partes de sílaba, como Malamud (2004) que, embora não afirme quais segmentos são apagados na haplologia, apresenta o seguinte exemplo do inglês:

$$
\text { proBABLY }>\text { proB'LY } \rightarrow \operatorname{proB}(A B) L Y \quad \text { 'provavelmente' }
$$

Com base no exemplo em (123), observa-se que os segmentos elididos são a vogal la/ e o segundo /b/, de acordo com o autor.

Battisti (2004: 33) afirma que a sílaba produzida no output em português é a segunda, com base em exemplos como:

$$
\text { completamenTE Diferente /te }+ \text { di }>\text { completamen(TE) Dlferente }
$$

No exemplo (124), o contexto segmental é formado por sílabas diferentes: as consoantes $/ t+d /$ diferem apenas no traço [vozeamento] (a primeira é [-vozeado] e a segunda é [+vozeado]); e as vogais /e + i/ diferem na altura (a primeira é [-alto, -baixo] e a segunda é [+alto, -baixo]). Segundo Battisti (2004), se o contexto segmental tiver sílabas diferentes, como no caso apresentado em (124), do corpus da autora, o resultado da 
haplologia (em que a segunda sílaba do contexto é produzida, e a segunda não é), é um indicativo de que a primeira é a apagada.

Finalmente, há uma terceira análise, que propõe que na haplologia temos os dois processos: fusão e apagamento (cf. Frota 1995, Bisol 2000, Tenani 2002, Battisti 2004). As autoras seguem a definição de haplologia de Sá Nogueira (1958), que defende que há três passos neste processo (cf. Capítulo 3, subseção 3.2.1). Inicialmente tem-se o apagamento da primeira vogal, e em seguida, opcionalmente, a fusão das duas consoantes. Um terceiro passo ainda possibilita ou não o encurtamento da consoante fundida, como ilustram os exemplos a seguir, a partir da sentença de Bisol:

\section{O maca(CO) COmeu todas as bananas}

$\begin{array}{lll}\text { a) } \operatorname{macaC}(O) \text { COmeu } & \text { b) macaC+COmeu } & \text { c) macaCOmeu }\end{array}$

apagamento da vogal

fusão das consoantes

encurtamento

output

$\begin{array}{ccc}{[\text { ma.ka.k.ko.mew] }} & {[\text { ma.ka.k.ko.mew] }} & \text { [ma.ka.k.ko.mew] } \\ \ldots . . & {[\text { ma.ka.k:o.mew] }} & {[\text { ma.ka.k.o.mew] }} \\ \ldots . . & \ldots . . & {[\text { ma.ka.ko.mew] }} \\ \text { [ma.ka.k.ko.mew] } & {[\text { ma.ka.k:o.mew] }} & {[\text { ma.ka.ko.mew] }}\end{array}$

Em (125)a), no primeiro passo, acontece a elisão vocálica de /o/, fazendo com que duas consoantes idênticas fiquem adjacentes $/ \mathrm{k} . \mathrm{k} /$; em seguida, há fusão das duas consoantes geminadas /k:/ (cf. (125)b), finalmente, a consoante alongada pode se encurtar, gerando a haplologia completa, como se vê em (125).

Como se pode observar, ainda são muitas as questões sobre o processo de haplologia, especificamente, e da queda de sílaba, em âmbito mais geral - esperamos que os resultados encontrados possam trazer mais luzes para uma futura resposta. Nosso trabalho não versa sobre estas questões, e assumimos que a queda de sílaba no português brasileiro tem uma natureza de apagamento (da primeira sílaba), com base em três indicativos: (i) no português brasileiro, sílabas postônicas (isto é, a primeira sílaba do contexto) são prosodicamente mais fracas que pretônicas (cf. Bisol 2003: 187, Leal \& Santos 2010) e são exatamente as postônicas as sílabas que desaparecem na haplologia; (ii) com base em Casali (1997), para quem, em contextos $\mathrm{V} \# \mathrm{~V}$, a grande maioria das 
línguas apagam a primeira vogal; e (iii) em Battisti (2004), segundo quem contextos em que as duas sílabas sujeitas ao processo são diferentes, há apagamento da primeira sílaba, e a segunda permanece. 


\section{CAPÍTULO IV}

\section{Metodologia}

Como vimos na subseção 2.1, esta tese se fundamenta na teoria fonológica gerativista e no modelo da sociolinguística variacionista para examinar dados de uma regra variável - a queda de sílaba. ${ }^{48}$ Utilizamos a ferramenta estatística GoldVarb X (cf. Sankoff, Tagliamonte \& Smith 2005) para a análise, programa que, em linhas gerais, oferece ao pesquisador o produto de cálculos estatísticos de uma regra variável.

No presente trabalho, a variável dependente (binária) é apagar a sílaba ou produzila: estas duas maneiras de falar variam ${ }^{49}$ a depender dos tipos de contextos (sociais e linguísticos). Com a variável dependente definida, buscamos as variáveis independentes, que são os condicionamentos que "pressionam" a preferência do falante por uma forma ou outra (apagar a sílaba ou não). Estas "pressões" são interpretadas pelo pesquisador via hipóteses formuladas que podem interferir no processo, pela construção de grupos de fatores independentes. Por exemplo, uma das hipóteses levantadas nesta tese (com base na literatura - cf. Tenani 2002, Battisti 2004, Pavezi 2006 e Leal 2006) é que não há bloqueio de queda de sílaba em nenhum nível prosódico; ainda, há um favorecimento do processo entre frases fonológicas. Assim, o informante seria "pressionado" a apagar mais sílabas no nível de frase fonológica (cf. subseção 4.1.4.1.4). Mas não é apenas uma variável que pode interferir no processo, mas diversas, atuando simultaneamente na variável dependente - neste trabalho são 14. É nesta etapa que vemos a valia do GoldVarb: o programa calcula como cada uma das variáveis independentes atua na variável dependente e também faz uma computação em que se obtém como as diversas variáveis independentes atuam, em conjunto, na variável dependente. Há dois tipos de computação dos dados: na análise univariada (ou unidimensional) obtêm-se resultados do efeito de uma

\footnotetext{
48 Agradeço à Profa Dr $^{a}$ Gisela Collischonn pelos comentários que me fizeram melhorar a exposição nesta seção.

49 O objeto de estudo numa pesquisa sociolinguística deve ser variável: o pesquisador busca dois (ou mais) "modos de se falar a mesma coisa" (Labov 1972).
} 
variável independente sobre a dependente (Guy \& Zilles 2007: 98), ou seja, o programa apresenta as frequências de uma variável independente em relação a uma dimensão da variável dependente (Brescancini 2002) - por exemplo na análise univariada, o GoldVarb pode oferecer a frequência de aplicação de queda de sílaba de acordo com as consoantes. $\mathrm{Na}$ segunda análise, chamada multivariada (ou multidimensional) Guy \& Zilles (2007: 50) explicam:

(...) é uma tentativa de modelar os dados como uma função de várias forças simultâneas, interseccionadas e independentes, que podem agir em diferentes direções. De fato, um dos produtos da análise é uma medida numérica do peso e da "direção" (favorável ou desfavorável) de cada força.

Há duas etapas na análise multivariada: o step-up e o step-down. O step-up é realizado de acordo com o número de variáveis independentes, com níveis de 0 a $x$, sendo $x$ o número de variáveis independentes estatisticamente relevantes mais um (Brescancini 2002: 36). No nível 0 do step-up, o programa calcula o input da interação de fatores, que é a probabilidade de aplicação da regra - ou seja, o valor obtido no input deve estar próximo da porcentagem de aplicação da regra (Brescancini 2002). Nos outros níveis do step-up, o programa faz cálculos com cada uma das variáveis independentes significativas, inserindo na computação cada variável uma a uma. No step-down, a computação é feita ao contrário, retirando as variáveis independentes não significativas uma a uma. Do step-up, o programa escolhe a melhor rodada (em termos de significância) e faz o mesmo com o step-down. Guy \& Zilles (2007: 166) explicam:

Normalmente, o step-up e o step-down vão escolher os mesmos grupos de fatores como significativos. Isto é, a lista dos grupos incluídos (selecionados) no step-up será equivalente à lista dos grupos não excluídos no step-down. Assim sendo, no final, a melhor rodada de cada procedimento será igual: a melhor análise do step-up incluirá exatamente os grupos que não foram excluídos pelo step-down.

O termo rodada é usado para indicar todo e qualquer produto do processamento de dados com um programa de regra variável (Brescancini 2002: 29): para indicar a computação dos dados feita pelo programa de regra variável (isto é, a comparação de 
análise de regra variável de um conjunto de dados - Tagliamonte 2006: 266); e para indicar cada um dos cálculos feitos dentro de uma etapa do step-up ou do step-down.

Uma vez explicitado o funcionamento da estatística na metodologia variacionista empregada neste trabalho, passamos a tratar, na próxima subseção, do envelope de variação.

\subsection{O envelope de variação}

Nesta subseção, apresento o modo com que trabalhamos a variável dependente, apresentando contextos onde é possível ou impossível de a variável ocorrer (Guy \& Zilles 2007: 36): em 4.1.1, está disposto como o corpus foi constituído; em 4.1.2, está como foi feita a coleta dos dados, com as restrições seguidas; em 4.1.3 está a fonética e como foram feitas as leituras dos espectrogramas; na subseção 4.1 .4 estão os grupos de fatores que podem intervir na variável dependente; e em 4.1.5, está o sumário das variáveis linguísticas e sociais.

\subsubsection{O corpus}

O corpus desta pesquisa é composto por 48 gravações $^{50}$ de 1 hora cada e, para a análise, foram desprezados os 10 primeiros minutos de cada entrevista. Os diálogos são seções do tipo documentador-informante, conduzidos de tal forma que as conversas fossem informais e os tópicos das entrevistas foram, basicamente, cinco: infância, adolescência, namoro/casamento, trabalho, ponto de vista do informante com relação a sua cidade natal (como era, como está hoje em dia). ${ }^{51}$ Os temas foram favoráveis a uma conversa "solta", com o intuito de que o informante prestasse atenção ao conteúdo do que estava falando, e desviasse sua atenção do modo de falar. ${ }^{52}$

No início de cada seção de gravação, os entrevistados eram informados de que fariam parte de uma pesquisa sobre diferenças de se viver em uma cidade grande e uma

\footnotetext{
5045 gravações foram conduzidas por mim e 3 delas foram feitas por Lívia Oushiro. Agradeço imensamente à pesquisadora pela condução destas 3 entrevistas.

51 Se o informante não seguisse os 5 temas, não houve intervenção do pesquisador, ou seja, o mais importante foi deixar a entrevista fluir.

52 Com esses temas conversacionais, buscamos nas entrevistas o vernáculo, definido por Labov (1972: 208) como "the style in which the minimum attention is given to the monitoring of speech."
} 
cidade pequena, sendo cientificados do uso do gravador. ${ }^{53}$ Apesar da informalidade buscada, os informantes estavam cientes da gravação, o que pode diminuir a espontaneidade nas entrevistas (cf. discussão sobre o paradoxo do observador, em Labov 1972). 54

A busca de informantes ${ }^{55}$ foi a mais aleatória possível, controlando-se as seguintes variáveis externas (cf. detalhamento das variáveis externas na subseção 4.1.4.2):

Tabela 5 - Variáveis externas para a constituição do corpus

\begin{tabular}{|c|c|}
\hline Variáveis & Fatores \\
\hline \multirow{2}{*}{ Escolaridade } & ensino fundamental \\
\cline { 2 - 2 } Gênero & ensino superior \\
\cline { 2 - 2 } & masculino \\
\hline \multirow{2}{*}{ Faixa etária } & feminino 20 a 35 anos \\
\cline { 2 - 2 } & mais de 50 anos \\
\hline \multirow{2}{*}{ Cidade } & Capivari \\
\cline { 2 - 2 } & Campinas \\
\hline
\end{tabular}

O número de informantes por célula foi 3 , resultando 48 gravações: 2 fatores para Cidades $\times 2$ fatores para Escolaridade $\times 2$ fatores para Gênero $\times 2$ fatores para Faixa Etária $=16 \times 3$ por célula $=48$ Informantes (48 horas gravadas) .

A partir destas entrevistas, fizemos uma primeira análise (com dados de 3 informantes), cujo objetivo foi o de examinar quais dados são, de fato, variações de queda de sílaba - como foi visto na seção 3, há bloqueio do processo fonológico em Capivari se as consoantes não tiverem o mesmo ponto de $\mathrm{C}$ e/ou o mesmo valor para contínuo, excetuando-se alguns itens lexicais (cf. Leal 2006 e subseção 5.1 .1 a seguir). Os resultados da primeira análise foram a base para se codificar e analisar o corpus variável de forma

\footnotetext{
53 Para as 45 gravações, utilizei o computador Toshiba Satellite M35X-S161, o software Audacity (versão 1.2.1) e o microfone de lapela Clone, Multimedia System. Para as 3 gravações conduzidas por Lívia Oushiro, foi utilizado um gravador Sony, modelo ICD-P320 IC.

54 Numa entrevista sociolinguística, o pesquisador deve tentar, ao máximo, superar o paradoxo do observador, definido por Labov (1972: 61-2) do seguinte modo: "(...) our goal is to observe the way people use language when they are not being observed. (...) the structure that exists independently of the analyst."

55 Todos os informantes passaram, pelo menos, $2 / 3$ da vida na cidade em análise (e ali moravam na ocasião da gravação). Outras pessoas que moraram menos que isto foram descartadas do corpus.
} 
precisa, excetuando-se os processos categóricos (cf. os resultados do trabalho piloto na subseção 5.1.1).

Na próxima subseção 4.1.2, apresento as restrições feitas para a coleta dos dados e, em 4.1.3, o envelope de variação.

\subsubsection{Coleta de dados: as restrições}

A seguir, apresento as 7 restrições seguidas na coleta dos tokens do corpus que, de forma resumida, são: i) há pelo menos uma consoante no ataque das sílabas do contexto; ii) empréstimos foram codificados de acordo com a fonologia do português; iii) os contextos segmentais têm uma mesma cavidade oral para as consoantes; iv) a primeira sílaba é fraca; v) computamos somente falas neutras; vi) o limite de frase entonacional foi usado para definir se um dado seria computado ou não; e vii) casos de apagamento do clítico não foram analisados.

A primeira restrição foi que as sílabas do contexto de queda devem ter, pelo menos, uma consoante no ataque, uma vez que o processo é entendido como condicionado pelas consoantes do ataque. Ademais, contextos $\mathrm{V} \# \mathrm{~V}$ podem produzir outros processos fonológicos que não a queda de sílaba (cf. subseção 3.2.2), como exemplificado a seguir:

$$
\begin{aligned}
& \text { o gaTO DE botas > o ga DE botas [ga.d3I.'bo.tes] queda de sílaba } \\
& \text { o gaTO Olhou > o gat[o]lhou ['ga.to.'Kow] degeminação } \\
& \text { o gaTO EStava > o gat[wi]stava ['ga.twis.'ta.ve] ditongação } \\
& \text { a gaTA EStava > a gat[i]stava ['ga.tis.'ta.ve] elisão }
\end{aligned}
$$

No contexto (126), há duas consoantes nas duas sílabas, o que permite a aplicação da queda de sílaba. Por outro lado, em (127)-(129), não há um contexto para este processo, já que a segunda sílaba não tem ataque: em (127), o processo fonológico que pode ser implementado é degeminação, resultado de duas vogais adjacentes /o/ de gato e /o/ de olhou; em (128), o contexto também é de duas vogais /o + e/ subjacentes que podem ditongar, tornando-se [wi]; finalmente, em (129), pode ocorrer a elisão vocálica da última vogal de gata, que aparece no contexto seguida de /e/ subjacente da primeira vogal da 
palavra estava.

Outra restrição ao se coletar os dados foi que a interpretação dos segmentos (e, consequentemente, a codificação do contexto segmental) foi feita de acordo com a fonologia do português, como nos exemplos a seguir, retirados do corpus:

$\begin{array}{llll}\text { (130) catchup } & > & \text { /kE.te.'fu.pe/ } \\ \text { (131) internet } & > & \text { /.inter'nete/ } \\ \text { (132) honda } & > & \text { /'hoNda/ }\end{array}$

As palavras acima entraram no português por empréstimo: em (130) e (131), as sílabas finais das palavras são abertas, com /e/ final, ao contrário do inglês, língua em que essas palavras são pronunciadas com sílabas travadas (catchup ['kætf.əp] e internet ['ın.t3r.net]); em (132), o que está grafado com a letra $h$ é o /r/ "forte", encontrado em palavras como carro. Para vocábulos estrangeiros como esses apresentados em (130) e (131), adotamos a proposta de Camara Jr. (1969: 28):

A praxe ortodoxa é escrever clube, Judite e assim por diante. Nas onomatopeias, em que não se adota essa praxe, a letra consoante final é entendida como uma sílaba e fica pressuposto um silábico não escrito.

O autor exemplifica que há uma sílaba final fonológica em onomatopeias com os versos de Guerra Junqueiro, ${ }^{56}$ em que este poeta faz uma rima de toc-toc com a palavra reboque, e explica (p. 29):

É fácil, com efeito, perceber que toc do primeiro e quarto verso rima com reboque (e portanto $-c$ equivale a -que) e tem duas sílabas para fazer dos versos em que se acham hendecassílabos como os demais versos. (...) Na realidade, as consoantes que podem ser decrescentes em português e figurar no declive da sílaba, travando o silábico, são /l/, /r/ e /z/."

56 Os primeiros versos de A Moleirinha, de Guerra Junqueiro, apresentados por Camara Jr. (1969: 29) são: "Pela estrada plana, toc-toc-toc, / Guia um jumentinho uma velhinha errante. / Como vão ligeiros, ambos a reboque, / Antes que anoiteça, toc-toc-toc, / A velhinha atrás, o jumentinho adiante". 
Assim, consideramos que não haja no português sílabas travadas com outras consoantes que não sejam /l/, /r/ e /z/.

A terceira restrição foi que apenas trabalhamos com os contextos segmentais que tenham Cavidade Oral das Consoantes iguais, isto é, os segmentos devem ter o mesmo ponto de $\mathrm{C}$ e o mesmo valor de [contínuo], tomando-se como base os resultados do estudo piloto (cf. subseção 5.1).

A quarta restrição para a coleta dos dados foi que primeira sílaba do contexto deveria ser fraca (cf. referências na seção 3), sem importar o acento nas sílabas adjacentes, como exemplificado nas grades métricas abaixo: ${ }^{57}$

(133) Ela aceiTA NUma boa.

$$
\begin{array}{ccccc}
a & \text { cei } & \text { TA } & \text { NU } & \text { ma } \\
{[\cdot} & \mathrm{x} & \bullet & {[\mathrm{x}} & \cdot
\end{array}
$$

... dava muito presente pra genTE TAMbém, né?

$$
\left.\begin{array}{cccc}
\text { gen } & \text { te } & \text { tam } & \text { bém } \\
{[\mathrm{x}} & \bullet
\end{array}\right]\left[\begin{array}{cc}
\cdot & \mathrm{x}
\end{array}\right]
$$

(b)

(a)

(d)

$$
\begin{aligned}
& \text { cons tru in do de va gar } \\
& {\left[\begin{array}{llll}
y & \bullet & x & \bullet
\end{array}\right]\left[\begin{array}{lll}
y & \bullet & x
\end{array}\right]}
\end{aligned}
$$

A sentença apresentada em (133) é um caso de não aplicação de queda de sílaba, em que aceita $(\cdot \mathrm{x} \cdot)$ está seguida da palavra numa, que possui uma sílaba forte seguida de outra fraca $(x \bullet)$; em (134) (sem aplicação do processo), a segunda palavra do contexto

\footnotetext{
57 A partir deste ponto, a sílaba forte está representada por "x", a fraca por "•" e "y" indica acento secundário, como na grade métrica em (135). Lembramos que as letras entre parênteses indicam o informante que proferiu a sentença.

58 Neste tipo de exemplo apresentado em (135), notamos que a primeira palavra do contexto de queda de sílaba é um verbo no gerúndio, construção que é comumente reduzida de construindo para construin $(d) o-1^{a}$ conjugação: brincando > brincan $(d) o$, 2a conjugação: correndo > corren $(d) o$ e $3^{\text {a }}$ conjugação: construindo > construin(d)o. Assim, um tema a ser investigado é se a redução comumente aplicada ao gerúndio favorece, desfavorece ou não tem qualquer efeito na queda de sílaba. Assim como em (112), podemos supor que haja uma ordenação de regras, em que a morfologia também tem um efeito. Não trataremos deste assunto nesta tese, deixando esta questão para trabalhos futuros (cf. nota 44). Agradeço à Profa Dra Luciani Tenani por me apontar esta questão.
} 
também é um iambo $(\cdot x)$, que possui uma sílaba fraca seguida de outra forte; e em (135), contexto em que houve queda de sílaba, há um acento secundário (representado por $y$ ) na primeira sílaba de devagar, seguido de uma fraca e outra forte $(\mathrm{y} \cdot \mathrm{x})$.

A decisão de não incluir na pesquisa sílabas fortes na primeira posição do contexto segmental tem base na literatura, já que todos os autores concordam que esta deve ser fraca (cf. Alkmim \& Gomes 1982, Tenani 2002, Battisti 2004, Pavezi 2006a e Leal 2006). Incluir dados sem importar o acento da primeira sílaba da segunda palavra também foi determinado pela literatura; neste caso os autores têm resultados controversos: enquanto Alkmim \& Gomes (1982) afirmam que a segunda sílaba do contexto segmental deve necessariamente ser fraca, Tenani (2002), Pavezi (2006a) e Leal (2006) encontraram resultados em que a segunda sílaba pode ser forte.

Além de apresentar os critérios que utilizamos para coletar os tokens das entrevistas e analisá-los, é importante explicitar também que tipos de dados foram desconsiderados (Tagliamonte 2006: 87). Levamos em conta somente dados de fala neutra, delimitados de acordo com o nível da frase entonacional. Assim, não foram computados hesitação (cf. exemplo (136) abaixo), ênfase (ver (137)) e momentos em que o informante riu (cf. (138)). ${ }^{59}$

(136) Hesitação: ... do laDO DO... do seu Arlindo

(137) Ênfase: Naquela noiTE, DEpois já acostumava, né?

(138) Risos:

Fiel era o cachorro, saBE? BRINcando comigo

As palavras sublinhadas na sentença em (136) indicam hesitação na fala da informante $b$, o que é confirmado pela repetição do clítico do; na sentença (137), houve ênfase na palavra noite na fala da informante $a$; na produção da sentença (138), a informante a riu. Casos como estes apresentam contextos segmentais favoráveis à queda de sílaba, quais sejam: em (136), o contexto é /do + do/, de laDO + DO; em (137), é /te + de/, de noiTE + DEpois, e em (138), é /be + briN/, de saBE + BRINcando. No entanto, exemplos como os apresentados acima foram descartados da computação porque não são

\footnotetext{
59 Apesar de ter havido variações em dados de hesitação e ênfase, decidimos por analisar apenas os dados de fala neutra, deixando estes tipos de variáveis para trabalhos futuros.
} 
neutros (caso da ênfase) ou criam modificações na produção que poderiam afetar os dados (casos de hesitação e risos).

A frase entonacional foi tomada como limite para computar ou não os tokens. Por exemplo, observe o parsing prosódico da sentença abaixo:

$$
\text { [... todos os ossos do corpo humaNO. }]_{\mathrm{I}}[\mathrm{NA} \text { terceira série }]_{\mathrm{I}}
$$

$(b)^{60}$

Em (139), há uma fronteira de frase entonacional separando as sílabas do contexto segmental /no + na/, e terceira e série aparecem sublinhadas para indicar que a informante $b$ enfatizou estas duas palavras. Já que não há ênfase no primeiro I, o contexto de ossos do entrou na análise; 61 mas o contexto formado pelas palavras terceira e série não foi computado. Quanto ao contexto /no + na/, de humano na, delimitado por duas frases entonacionais (a primeira sem e a segunda com ênfase), suas sílabas também não entraram na computação dos dados - por causa da ênfase na segunda frase entonacional (terceira e série).

Em (139), o contexto /do + cor/ da sentença todos os ossos DO CORpo humano ilustra outro tipo de sequência que não foi analisada. Ele está relacionado ao processo fonológico de apagamento clítico. Veloso (2003) mostra que, diferentemente dos outros processos fonológicos de sândi externo (ditongação e degeminação) no português brasileiro, a elisão vocálica é bloqueada se a primeira palavra for monossilábica, exemplificando o bloqueio da seguinte forma (Veloso 2003: 58):

$60 \mathrm{Na}$ fala da informante $b$ apresentada em (139), há 8 contextos de queda de sílaba: (i) toDOS OS, (ii) OS Ossos, (iii) oSSOS DO, (iv) DO CORpo, (v) corPO HUmano, (vi) humaNO NA, (vii) NA TERceira, (viii) terceiRA SÉrie. Primeiramente, esclarecemos que contextos com sílabas sem ataque não foram computados; em segundo lugar, como foi dito em 4.1.1, foram feitas duas análises e, na primeira delas (cf. o estudo piloto em 5.1), não foi empregada a terceira restrição, ou seja, casos como ossos do em (139) foram contados - em /s $+\mathrm{d} /$ há uma mesma cavidade oral, mas os valores para contínuo são diferentes, já que /s/ é [+contínuo] e /d/ é [-contínuo]; . Na segunda análise (definitiva, cf. resultados em 5.3), foram apenas computados dados em que os contextos consonantais tivessem uma mesma Cavidade Oral (quer dizer, um mesmo ponto de $\mathrm{C}$ e o mesmo valor de [contínuo]) e, neste caso, dados como ossos do não entraram nas rodadas.

61 Contexto $/ s+d /$, incluso somente na primeira análise (cf. nota anterior e o estudo piloto em 5.1). 


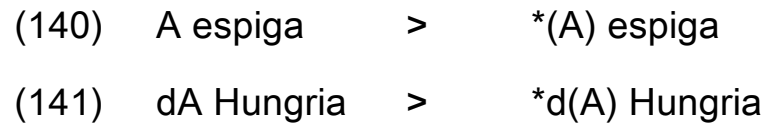

Pavezi (2006a), seguindo Veloso (2003), levanta a hipótese de que há bloqueio de haplologia se o monomorfema de ocupar a primeira posição no contexto do processo, e esta hipótese se confirma em seu corpus, já que, dos 38 contextos, numa sequência de + item lexical, não houve nenhuma aplicação de haplologia, como exemplificado abaixo (Pavezi 2006a: 67):

(142) ....a espiga de milho depois *(DE) DEbulhada... o que fica... chama sabugo

Além deste fator, um outro - metodológico - se coloca. Observe o exemplo abaixo retirado do corpus do presente trabalho:

(143) [pre'si.zv.fa'ze]

Este tipo de dado é ambíguo, pois, a depender do dialeto do português brasileiro, a produção apresentada em (143) pode ser resultado de duas sentenças:

\section{(144) Preciso de fazer \\ (145) Preciso fazer}

Em (144), há um clítico entre os dois verbos no sintagma e, em (145), o clítico não aparece na produção do falante. Em (143), não temos como afirmar se houve apagamento do clítico de em (145) ou se o informante já está produzindo esta sentença sem o clítico (portanto, não há apagamento, como em (144)). Em nossos dados, tivemos a seguinte produção: 
$(146)$
Onde é o posTO DE SAúde hoje
$>\quad$ ['po.s:a.'u.de]
a) $1^{\circ}$ contexto: posTO DE saúde
['poz.d]I.sa'u.dfI]
b) $2^{\circ}$ contexto: posto DE SAúde
['pos.tu.sa'u.dfr]

(b)

Em (146), há dois possíveis contextos para haplologia: (146)a)/to + de/ e (146)b) /de + sa/. Se ocorresse a queda de sílaba no primeiro contexto, o esperado seria a produção ['poz.dfr.sa'u.dfr] e, se ocorresse no segundo contexto, o esperado seria a produção ['pos.tu.sa'u.dfr]. Entretanto, a informante $b$, além da sílaba/to/, apagou também o clítico, pos(TO DE) saúde. Abaixo está o espectrograma do exemplo (146), em que a informante $b$ produziu a sentença com apagamento de duas sílabas:

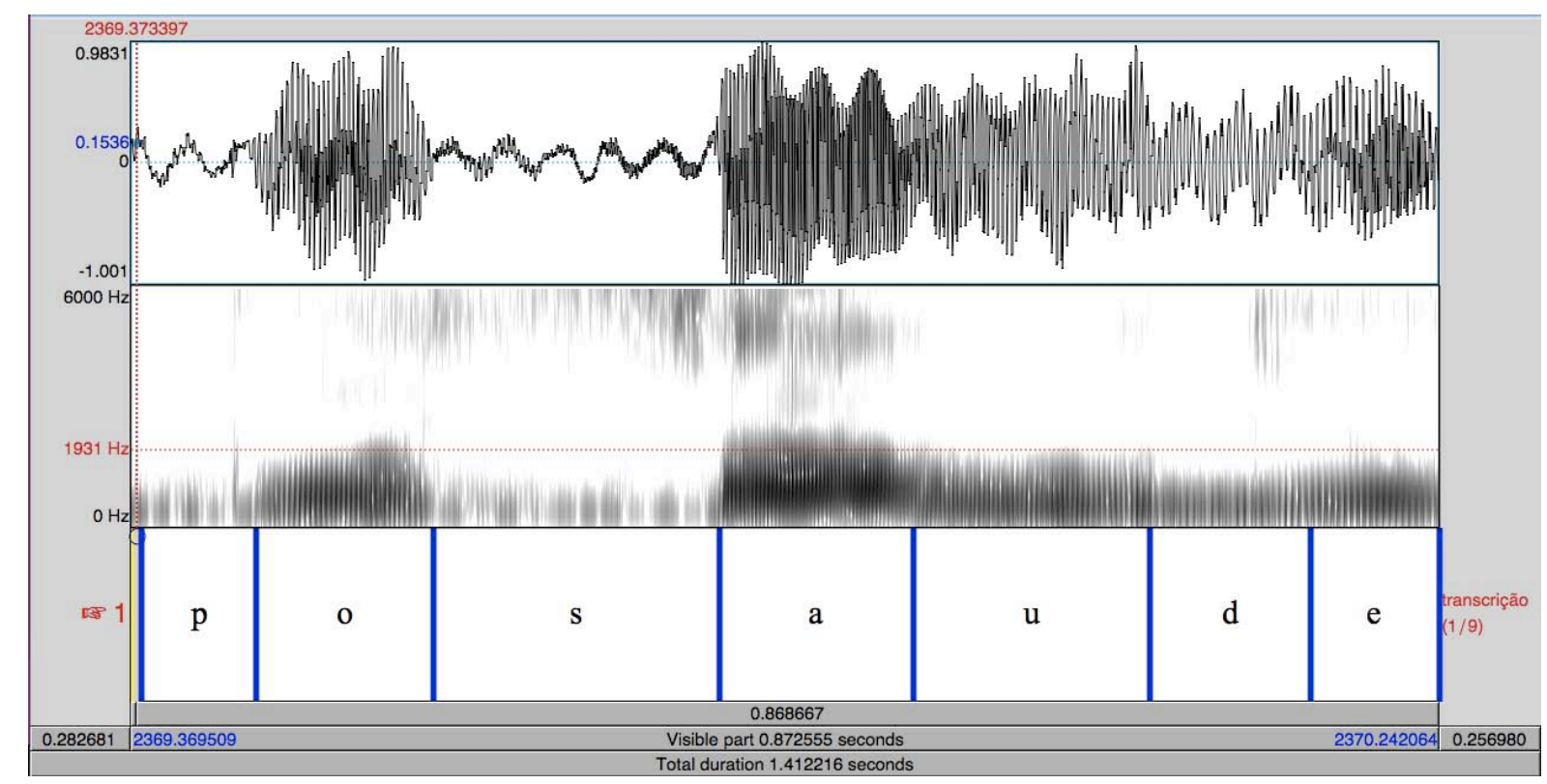

Gráfico 4 - Espectrograma de queda do clítico: posTO DE SAúde > pos(TO DE) saúde ['pos:a'ude]

O caso em (146) é menos claro quanto a uma possível variação dialetal (não há como saber se o clítico está no nível fonológico em (146), posto de saúde, e depois foi apagado posto (de) saúde, ou se o informante já produziu posto saúde (sem o clítico) e, neste caso, apagou apenas a última sílaba de posto), no entanto, é um indício de que devemos ter cautela ao analisar dados deste tipo.

Assim, pela complexidade e especificidade que há nesse tipo de queda de sílaba (o 
apagamento do clítico), dados ambíguos como (146) não foram computados.

$\mathrm{Na}$ subseção a seguir, apresento as técnicas utilizadas na análise fonética dos dados.

\subsubsection{A fonética}

$\mathrm{Na}$ constituição de um corpus, os dados podem se apresentar ao investigador de dois modos opostos: por um lado, há uma preferência de que sejam os mais espontâneos possíveis; por outro, os dados devem ser acusticamente perfeitos. Nesta dualidade entre espontaneidade versus boa acústica, o pesquisador pode ponderar se é melhor uma gravação em que o monitoramento da fala (pelo informante) é mínimo, mesmo que a gravação resulte em ruídos - o que pode comprometer a análise fonética -, ou fazer as entrevistas numa cabine acústica - com o custo da perda de espontaneidade do informante, prejudicando a busca do vernáculo (cf. Labov 1972: 208).

No presente trabalho, procuramos unir as duas metodologias, buscando espontaneidade na fala do informante (com temas conversacionais do cotidiano dos informantes, entrevistas feitas na casa ou no trabalho da pessoa) e, ao mesmo tempo, evitando ao máximo ruídos externos nas gravações. Por exemplo, para que o som fique mais "limpo", colocamos o microfone de lapela (unidirecional) o mais próximo e confortável possível do informante; 62 marcamos, sempre que possível, as entrevistas para momentos silenciosos - à noite ou logo no começo do dia. Adicionalmente, todas as gravações foram feitas em mono, com uma faixa que vai até aproximadamente $11 \mathrm{kHz}^{63}$ (com uma taxa de amostragem de $22050 \mathrm{~Hz}$ - cf. Ladefoged 2003: 26).

Nas gravações, em consequência de se buscar o vernáculo, os sons não são tão perfeitos quanto os de testes numa cabine acústica. Então, se o segmento parece ter sido apagado (não aparece a soltura de um /t/, por exemplo, típica destes tipos de segmentos), mas o tempo dele permaneceu, estes contextos foram contados como não aplicação de

62 Feagin (2002: 24) explica que “(...) some types of equipment have abiding advantages. The lavaliere microphone improves the quality of the sound and minimizes the speaker's attention to the recording mechanism." Assim, o uso do microfone de lapela não atrapalha a espontaneidade do informante.

63 Uma taxa de amostragem de $22050 \mathrm{~Hz}$ implica que as gravações não vão além de $11 \mathrm{kHz}$ e, mesmo com a possibilidade de perda de frequências mais altas, não há perda de informação nas análises para o propósito desta tese. 
queda de sílaba. Em alguns casos extremos, em que o espectrograma, os formantes ou o pitch não ajudaram na percepção para definir se houve ou não a aplicação da queda de sílaba, os contextos não foram computados na análise.

A coleta de todos os dados foi feita com a ajuda de dois programas: o Praat (Boersma \& Weenink 2010), para ouvir as gravações e examinar os espectrogramas; e o Excel, para codificar e armazenar os dados.

Nas análises dos espectrogramas com o Praat (Boersma \& Weenink 2010), a frequência default utilizada foi visualizar os sons a $6 \mathrm{kHz}$ (variando, por exemplo, com as fricativas, em que aumentamos para $10 \mathrm{kHz}$ ou $12 \mathrm{kHz}$, a depender do segmento), e a resolução na tela variou de 0,5 a 1 segundo, aproximadamente.

Como foi dito em 4.1.1, foram utilizados 50 minutos de cada gravação, e a coleta de todos os dados foi feita diretamente no Praat: tomamos cada arquivo de gravação (em mp3) e, a partir dele, criamos um arquivo de camada de texto (text grid) para que pudéssemos anotar o tempo (apresentado em segundos pelo Praat) em que houve contextos de variação de queda de sílaba. Se a aplicação ou a não aplicação de queda de sílaba no contexto em questão fosse facilmente determinada (de oitiva), ficava anotado o tempo do contexto no arquivo de text grid do Praat e, em seguida, eram anotados no Excel: o tempo do contexto, a primeira palavra, a segunda palavra, o informante e a variante produzida (aplicação ou não aplicação). Nesta etapa, foram marcados também quais eram as consoantes e vogais do contexto e as estruturas das duas sílabas, marcadas separadamente em uma coluna no Excel. Adicionalmente, marcamos também os fatores para prosódia (cf. 4.1.4.1.4), pois marcar os níveis da hierarquia prosódica depende de como o informante proferiu a sentença. Por exemplo, há uma única frase entonacional na sentença [o copo quebrou] ${ }_{\mathrm{I}}$, mas, se o informante produzir [o copo] $]_{\mathrm{I}} / /$ [quebrou] $_{\mathrm{I}}$, em que "//" indica uma pausa inserida entre copo e quebrou, há duas frases entonacionais distintas. Fazendo estes procedimentos, a coleta de 1 informante estava finalizada e, neste momento, voltávamos ao arquivo do Excel a fim de codificar as outras informações, contando com a ajuda dos recursos oferecidos pelos programa. ${ }^{64}$ Terminadas as codificações de um informante,

64 Os recursos do Excel ajudaram também na conferência dos fatores, a fim de verificar se uma sílaba /do/ estava indicada por $d$ na coluna de consoantes e o na coluna de vogais, por exemplo. 
passávamos a outro - deste modo, cada informante era finalizado com a codificação pronta.

Nos contextos em que houvesse a possibilidade de aplicação do processo, a janela era diminuída para a faixa de 0,5 a 1 segundos, marcando nos arquivos de text grid, além do tempo da ocorrência, também os segmentos relevantes. Portanto, todos os contextos de queda de sílaba desta tese foram checados nos espectrogramas.

A fim de verificar se toda a sílaba foi elidida, a vogal pode ser mais facilmente comprovada, observando-se se restou ou não formantes deste tipo de segmento. Com relação às consoantes plosivas desvozeadas /t, p, k/, utilizamos 3 métodos:

(i) observar a soltura da consoante no espectrograma;

(ii) verificar, de oitiva se há 1 tempo da consoante;

(iii) se estes dois procedimentos ainda não determinarem se houve apagamento ou não, comparar a duração da consoante com uma consoante igual a ela (aquela que estiver mais próxima na gravação, com as mesmas características acentuais).

Para plosivas sonoras /d, b, g/, utilizamos os mesmos procedimentos apresentados de (i)-(iii), mas é mais fácil verificar a produção (ou não) destes segmentos do que a de desvozeadas, já que aquelas têm o adicional da vibração das cordas vocais, que pode ser observado pela barra de sonoridade (há também a ferramenta chamada pitch, ${ }^{65}$ que pode fornecer, pelo gráfico, se há ali uma consoante [vozeado]).

Com relação às fricativas, além de utilizarmos os procedimentos de (i)-(iii), foram aumentados as tamanhos (na vertical) do espectrograma, passando de $6 \mathrm{kHz}$ a $10 \mathrm{kHz}$ ou $12 \mathrm{kHz}$, para visualizar frequências mais altas. Adicionalmente, observamos o pitch e a barra de sonoridade das fricativas sonoras. Outro método utilizado foi tocar o som ao contrário na identificação de fricativas (sound in reverse), visto que é mais fácil identificar um offglide se fizer este som parecer um onset (Ladefoged 2003: 27).

65 Segundo Ladefoged (2003: 75) "Strictly speaking, pitch is an auditory property - something you hear. It is not an acoustic property - an aspect of the sound wave that you can measure. From a practical point of view when discusssing the pitch of the voice, it can usually be said to be the rate at which vocal fold pulses recur, and thus the fundamental frequency of the sound wave." 
Finalmente, saliento que os procedimentos apresentados nesta subseção são recursos adicionais de análise acústica. Para uma análise detalhada dos segmentos (consonantais), refiro o leitor ao capítulo 3 de Ladefoged (2003) e ao capítulo 6 de Ladefoged (2006).

\subsubsection{Os grupos de fatores}

Nesta subseção, apresento todas as variáveis linguísticas e sociais empregadas neste trabalho. Lembramos que, na codificação definitiva, computamos apenas os contextos em que houvesse cavidade oral das consoantes iguais (cf. as restrições em 4.1.2). Exemplificando contextos de queda de sílaba, temos:

$$
\text { per(TO) DA Unicamp, saBE BArão geralDO, NÉ? }
$$

Na sentença proferida em (147), foram coletados os seguintes tokens:

\begin{tabular}{|c|c|c|c|}
\hline (148) & 10 token: & $\operatorname{per}(\mathrm{TO}) \mathrm{DA}$ & /to + da/ \\
\hline (149) & $2^{\circ}$ token: & saBE BArão & $/ \mathrm{be}+\mathrm{ba} /$ \\
\hline (150) & 3o token: & GeralDO NÉ & $/ \mathrm{do}+\mathrm{n} \varepsilon /$ \\
\hline
\end{tabular}

Nos contextos apresentados em (148)-(150), as consoantes têm uma mesma cavidade oral: em (148), há duas coronais [-contínuo] /t $+d /$; em (149), há duas labiais [contínuo] /b + b/; e em (150), há também duas coronais [-contínuo], com a diferença também em nasalidade: /d/ é uma consoante oral e $/ \mathrm{n} /$ é uma nasal. Assim, há 3 ocorrências de queda de sílaba, sendo que apenas em (148) houve aplicação do processo.

Como dito, a variável dependente neste trabalho é binária, com uma variante de aplicação de queda de sílaba e ao outra de não aplicação do processo:

Variável dependente de queda de sílaba, com os fatores:

1. aplicação

2. não aplicação apagamento de sílabas

permanência de sílabas 
Apresento abaixo exemplificações do corpus da variável dependente:66

$$
\text { ... a gen(TE) TAva fazendo os cálculos. } \quad(m)
$$

Em (151), observamos que a informante $m$ produziu a sentença com queda de sílaba; não houve aplicação do processo com o mesmo contexto /te + ta/, como apresentado em (152) na fala da informante $a$.

As variáveis estão apresentados nas subseções a seguir: os linguísticos estão na subseção 4.1.4.1 a seguir e as variáveis sociais em 4.1.4.2.

Todas as exemplificações no envelope são do corpus utilizado neste trabalho, e cada par dos exemplos ilustra a aplicação e a não aplicação de queda de sílaba.

\subsubsection{Os grupos de fatores linguísticos}

Nas subseções que seguem, estão as variáveis independentes internas (linguísticas) que podem favorecer/desfavorecer a queda de sílaba, quais sejam: o contexto segmental (ver subseção 4.1.4.1.1); a estrutura das sílabas (ver 4.1.4.1.2); os acentos (tanto da palavra que pode sofrer o processo quanto daquela que a segue - em 4.1.4.1.3); a estrutura prosódica (cf. 4.1.4.1.4); o tamanho da palavra sujeita à queda, contado em número de sílabas (ver 4.1.4.1.5); e, finalmente, a frequência de uso da palavra sujeita ao apagamento (cf. 4.1.4.1.6).

\subsection{Contexto segmental}

Como foi visto na seção 3, Alkmim \& Gomes (1982) afirmam que há um tipo de apagamento de sílaba chamado pelas autoras de uma "regra diferente" (cf. Alkmim \& Gomes 1982: 50), pois é um processo fonológico que só ocorre com determinados itens lexicais, como pode. Para a haplologia, vimos que o contexto consonantal não se restringe a /t/ e /d/ (Alkmim \& Gomes 1982), já que há a possibilidade de aplicação com outras

66 Lembramos que os contextos segmentais do processo estão em maiúsculas e os parênteses indicam apagamento. Ainda, as letras entre parênteses depois de cada exemplo identificam o informante que articulou a sentença. 
consoantes (para o português brasileiro, cf. Bisol 2000 e Pavezi 2006a). Leal (2006) une a elisão silábica e a haplologia como um único processo fonológico (a queda de sílaba), pois ambas têm as mesmas características fonológicas - estes segmentos devem ter, internamente, o mesmo ponto de C e o mesmo valor para o traço [contínuo] (cf. subseção 3.3). Com relação às vogais, enquanto Alkmim \& Gomes (1982) afirmam que a haplologia só ocorre com segmentos vocálicos [+alto] (sendo o processo bloqueado com outras vogais), Pavezi (2006a) e Leal (2006) explicam que há variação de haplologia também com vogais [dorsal] (cf. seção 3.2.1), ou seja, não há bloqueio do processo com /a/. Assim, decidimos sistematizar quantitativamente uma possível variação na aplicação do processo, a depender da vogal que preenche as sílabas.

Com base nestes resultados, podemos entender o contexto segmental como o mais importante efeito, já que é a partir dele que se define a queda de sílaba (cf. subseção 3.2.1).

Assim, o contexto segmental foi codificado de várias formas, sempre unindo a primeira e a segunda sílabas, com o intuito de verificar quais combinações interferem ou não na queda de sílaba. As configurações foram as seguintes:

- Igualdade de Segmentos nas sílabas CV (ver subseção 4.1.4.1.1.1);

- Cavidade Oral das Consoantes (ver 4.1.4.1.1.2);

- Cavidade Oral das Consoantes com Distinção de Segmentos [nasal] (ver 4.1.4.1.1.3); e

- Cavidade Oral das Vogais (cf. 4.1.4.1.1.4).

\subsection{Igualdade de Segmentos nas Sílabas CV}

Vimos que na haplologia (cf. referências apresentadas em 3.2.1), sílabas idênticas ou semelhantes têm uma maior propensão ao apagamento, ou seja, quanto mais próximos forem os traços dos segmentos nas duas sílabas, há uma maior probabilidade de aplicação do processo. A hipótese para esta variável é que quanto mais parecidas forem segmentalmente as sílabas, maior é a propensão à queda. Os fatores são: ${ }^{67}$

${ }^{67}$ Agradeço ao Prof Dr Emilio Gozze Pagotto por me chamar a atenção para esta variável. 
1. consoantes iguais, vogais iguais

2. consoantes iguais, vogais diferentes

3. consoantes diferentes em [vozeamento], vogais iguais

4. consoantes diferentes em [vozeamento], vogais diferentes

5. consoantes diferentes em [nasal], vogais iguais

6. consoantes diferentes em [nasal], vogais diferentes

7. consoantes diferentes em [anterior, distribuído]

Dito de forma resumida, além de verificar se sílabas iguais favorecem o processo, o intuito com esta variável de Igualdade de Segmentos nas sílabas é verificar como os traços [vozeamento], [nasal] e [anterior, distribuído] das consoantes podem interferir na queda de sílaba. Com relação às vogais, a cada especificação diferente de consoantes, propusemos também vogais iguais e diferentes, a fim de verificar se as vogais também intervêm no processo (cf. referências apresentadas em 3.2.1).

Com o primeiro e o segundo fatores (cf. itens 1 e 2 acima), buscamos identificar até que ponto a Igualdade de Segmentos nas sílabas pode favorecer o processo, como exemplificado abaixo:

(154) máquiNA NA usina

(155) apareci(DA) DO norte

(156) acabaDO DE trocar a letra

Os exemplos (153) e (154) têm sílabas idênticas, /de + de/ e /na + na/, respectivamente, enquanto que (155) e (156) têm consoantes iguais $/ d+d /$, mas diferem quanto ao contexto vocálico: /a $+\mathrm{o} / \mathrm{e} / \mathrm{o}+\mathrm{e} /$, respectivamente. A hipótese é que haja uma tendência maior à queda nos exemplos (153) e (154) do que em (155) e (156), já que aqueles têm sílabas idênticas.

Uma vez que há possibilidade de queda de sílaba com consoantes diferentes em [vozeamento] (cf. referências em 3.2.1), o objetivo com os fatores 3 e 4 é verificar como o traço [vozeamento] pode intervir no apagamento de sílaba. Observe os exemplos (157)(160): 


$\begin{array}{lll}(157) & \text { ajudan(TE) DE pintor } & \text { (C) } \\ (158) & \text { ajudanTE DE pedreiro } & \text { (C) } \\ (159) & \text { mui(TO) DIfícil } & \text { (j) } \\ (160) & \text { muiTO DIfícil } & \text { (h) }\end{array}$

As vogais são idênticas em (157) e (158), enquanto que as consoantes diferem apenas em vozeamento, e houve aplicação na primeira e não aplicação no segundo exemplo. Da mesma forma, os exemplos (159) e (160) são de aplicação de queda de sílaba e de não aplicação, respectivamente, e, além de as consoantes diferirem em [vozeamento], há uma diferença também nas vogais, já que os contextos são /o + i/. A hipótese é que haja maior propensão à queda de sílaba nos dois primeiros exemplos, já que as vogais são idênticas.

Para Alkmim \& Gomes (1982), de Lacy (1999), Tenani (2002), Battisti (2004), Pavezi (2006a) e Leal (2006), o traço [vozeamento] não interfere na haplologia (e na elisão silábica, cf. Leal 2006), pois o processo não é bloqueado se as consoantes diferirem neste traço. Ao comparar, de um lado, os fatores 1 (consoantes iguais, vogais iguais) e 2 (consoantes iguais, vogais diferentes) e, de outro, os fatores 2 (consoantes diferentes em [vozeamento], vogais iguais) e 3 (consoantes diferentes em [vozeamento], vogais diferentes), poderemos verificar de que forma o [vozeamento] pode interferir no processo: se não interfere (neste caso, a tendência entre os fatores 1 e 2 versus 3 e 4 deve ser a mesma), ou se atua na queda de sílaba (aqui, haveria uma diferença na tendência de 1 e 2 versus 3 e 4).

Os fatores 5 e 6 indicam contextos consonantais que diferem em [nasal], sem importar se este traço está na primeira ou na segunda consoante:

$\begin{array}{lll}(161) & \text { conversan(DO) NO telefone } & \text { (A) } \\ (162) & \text { choranDO NO meio do caminho } & \text { (N) } \\ (163) & \text { do(NO) DO mercado } & \text { (T) } \\ (164) & \text { doNO DO bar } & \text { (B) } \\ (165) & \text { chegar nu(MA) POsição melhor } & \text { (k) } \\ (166) & \text { costuMA PEdir } & \text { (S) }\end{array}$


Os exemplos (161) e (162) têm uma coronal oral /d/ seguida de uma nasal /n/ e são, respectivamente, casos de aplicação e de não aplicação de queda de sílaba; em (163) e (164), as consoantes também diferem em [nasal], mas nestes dois exemplos o contexto $/ \mathrm{n}+$ d/ é de uma coronal nasal seguida de uma consoante oral; os casos em (165) e (166) são de contextos $/ m+p /$, em que além da diferença em [nasal] das consoantes, as vogais também se diferem (cf. /a + o/ em (165) e /a + e/ em (166)).

As consoantes nasais são [-contínuo] na cavidade oral; assim, nos exemplos de (161)-(166), os contextos têm consoantes [-contínuo] na primeira e na segunda posições. As análises existentes apontam que as consoantes devem ser /t/ ou /d/ (Alkmim \& Gomes 1982) ou ter um mesmo ponto de C e [contínuo] (Leal 2006). Se só estes dois traços forem importantes, a previsão é que, em $/ n+d /$, por exemplo, tenha a mesma tendência à queda de sílaba do que $/ t+d /$, por exemplo. Assim, isolar as nasais permite observar se mais um traço, a saber [nasal], influi na aplicação do processo.

A análise experimental de Leal (2006) aponta que há possibilidade de queda de sílaba se as consoantes tiverem uma diferença em [anterior, distribuído], como exemplificado abaixo (cf. Leal 2006: 84):

(167) babo(SA) CHEIrosa

Em (167), as duas consoantes são coronais [+contínuo], a primeira é [+anterior, -distribuído] e a segunda é [-anterior, +distribuído], e a queda de sílaba pode acontecer. É interessante notar que, se o ponto de $C$ deve ser igual, tudo abaixo deveria ser igual, mas [anterior, distribuído] é diferente e ocorreu (cf. a representação da geometria de traços em Clements \& Hume (1995: 292) e Gráfico 2 na subseção 2.2.1). Assim, a pergunta que se faz é: se as consoantes forem diferentes em [anterior, distribuído], a aplicação é produtiva? Assim, o fator 7 deve indicar se há um efeito quantitativo no caso de as consoantes diferirem nestes traços, como exemplificado a seguir:

(168) ...laçar cabe(ÇA). JÁ vamos fazer uma?

(169) paSSA JAguariúna 
Os contextos consonantais em (168) e (169) são os mesmos /s + $3 /$, ou seja, estes segmentos diferem em [vozeamento] e [anterior, distribuído]; as vogais são /a + a/ idênticas e o processo pode ser aplicado, como em (168), ou não, como em (169).

Neste fator, não distinguimos as vogais porque os dados não tiveram uma distribuição ortogonal: para consoantes diferentes em [anterior, distribuído], com vogais iguais, a frequência foi de apenas $2 / 28$, enquanto que para consoantes diferentes em [anterior, distribuído], com vogais diferentes, houve knockout (de 27 dados, não houve nenhuma aplicação de queda de sílaba). Dessa forma, esses dados foram unidos num único fator, totalizando uma frequência de 2/55 - apesar do baixo número de ocorrências, esse tipo de configuração possibilitou obtermos os pesos relativos das análises multivariadas.

Finalmente, vale salientar que todas as sílabas que tenham estruturas diferentes de CV não entraram nesta variável por razões qualitativas, já que, a fim de verificar a Igualdade de Segmentos das sílabas, devemos controlar a Estrutura Silábica - de outra forma, haveria mais interferências na variável do que apenas os segmentos. ${ }^{68}$ Por exemplo, para analisarmos sílabas CCV, deveríamos ter de controlar tanto o segmento quanto a sua posição na sílaba. Chamamos a atenção que não estamos afirmando que a estrutura silábica não interfere na queda de sílaba; ao contrário, esta foi uma variável controlada, como se vê em 4.1.4.1.2. Devemos esclarecer que o intuito com esta variável foi ver até que ponto uma gradação de sílabas com segmentos totalmente iguais até sílabas com segmentos totalmente diferentes pode interferir no processo. E este objetivo só pode ser atingido com sílabas que tenham estruturas iguais $\mathrm{CV}$, embora com conteúdos diferentes.

\subsection{Cavidade Oral das Consoantes}

Outro modo de rodar o contexto segmental foi codificar a primeira e a segunda consoantes de acordo com suas cavidades orais (ponto de C e valor para [contínuo]), e propusemos os seguintes fatores:

\footnotetext{
68 Não levamos em conta 2243 tokens, quais sejam: 1315 de contextos CV+outros, 318 tokens de CCV+outros, 46 de CCVC+outros, 497 ocorrências de CVC+outros, 4 de CVCC+outros, 2 ocorrências com CCgV+CV, 54 tokens de estruturas $\mathrm{CgV+outros,} 3$ de $\mathrm{CgVC}+$ outros, 1 com $\mathrm{CVg}+$ outros e 3 contextos com sílabas CVgC+outros.
} 
1. duas consoantes coronais [-contínuo];

2. duas consoantes coronais [+contínuo];

3. duas consoantes labiais [-contínuo];

4. duas consoantes labiais [+contínuo]; e

5. duas consoantes dorsais. ${ }^{69}$

Observe as sentenças a seguir retiradas do corpus, de aplicação e não aplicação de queda de sílaba, em que exemplifico cada um dos fatores apresentados acima de 1-5. Para uma melhor visualização, contextos com duas consoantes coronais [-contínuo] estão representadas por $/ \mathrm{t}+\mathrm{t} /$; ambientes $/ \mathrm{s}+\mathrm{s} /$ representam duas consoantes coronais [+contínuo]; $/ p+p /$ denota duas consoantes labiais [-contínuo]; /f+f/, duas consoantes labiais [+contínuo]; e duas consoantes dorsais são descritas por $/ \mathrm{k}+\mathrm{k} /$ :

$\begin{array}{llll}(170) & t+t & \text { faculda(DE) DE letras } & (P) \\ (171) & t+t & \text { quanDO TÁ saindo a criançada da escola } & (a) \\ (172) & s+s & \text { a polí(CIA) CHEgou } & (B) \\ (173) & s+s & \text { não preciSA SE matar } & (b) \\ (174) & p+p & \text { tem(PO) PRA aposentadoria } & (k) \\ (175) & p+p & \text { mesMO PRA mim } & (i) \\ (176) & f+f & \text { não ta(VA) FAzendo nada de errado } & (m) \\ (177) & f+f & \text { taVA FAzendo pós } & (P) \\ (178) & k+k & \text { lógi(CO) QUE não } & (K) \\ (179) & k+k & \text { nunCA CAí } & (p)\end{array}$

Na produção apresentada em (170), há duas coronais [+vozeado], com aplicação de queda de sílaba; em (171), as consoantes diferem em [vozeamento] e não há aplicação do processo. Estes dois casos foram codificados como coronais /t+t/ [-contínuo], sem importar

69 Nesta tese, todas as consoantes dorsais encontradas no corpus são [-contínuo] - /k/ e /g/. No português brasileiro, o/r/ forte em rato pode ser produzido de duas formas: com um [h], uma laringal [+contínuo, -vozeado], como em [ha.tv]; ou com [x], uma dorsal [+contínuo, +vozeado], como em [xa.tv]. No entanto, este tipo de contexto $/ \mathrm{r}+\mathrm{r} /$ forte não foi encontrado no corpus. Assim, já que a outra possibilidade de dorsais $[\mathrm{x}]$ para $\mathrm{O}$ português brasileiro [+contínuo] não apareceu no corpus, deste ponto em diante, o valor de [contínuo] para dorsais não será mais indicado - será sempre uma dorsal [-contínuo]. 
o traço [vozeamento], já que nesta variável, observamos apenas a cavidade oral. Em (172), o contexto consonantal é $/ \mathrm{s}+\int /$ e, em (173), é $/ z+s /$. Estes casos foram codificados como coronais [+contínuo] e, como se nota nos exemplos, não importam os traços [anterior, distribuído], ou seja, controlamos, nesta variável, a cavidade oral (ponto de C e [contínuo]) o traço [vozeamento] está abaixo de [laringal], cf. no Gráfico 2 na subseção 2.2.1. No exemplo (174), há aplicação com as consoantes desvozeadas $/ p+p /$, enquanto que não houve aplicação do processo com os segmentos $/ m+p /(\operatorname{ver}(175))$. A codificação aqui foi unir estes casos em um fator labial [-contínuo], já que o traço [nasal] não importa, como vemos a diferença entre as consoantes em (175). As labiais [+contínuo] /f+f/ foram codificadas como apresentado nos exemplos (176) e (177), em que os contextos consonantais são um mesmo $(/ \mathrm{v}+\mathrm{f} /) \mathrm{e}$, novamente, as diferenças em [vozeamento] não foram levadas em conta. Finalmente, os exemplos (178) e (179), com contextos consonantais $/ \mathrm{k}+\mathrm{k} /$, representam como foram codificadas as dorsais.

A hipótese levantada para esta variável é que há uma maior tendência à aplicação de queda de sílaba com segmentos coronais, uma vez que estes segmentos são subespecificados em diversas línguas (cf. Paradis \& Prunet 1991 e Fikkert \& Levelt 2006) e, mesmo no português brasileiro, estudos reportam que é com /t/ e /d/ que a queda de sílaba ocorre (Alkmim \& Gomes 1982).

\subsection{Cavidade Oral das Consoantes com Distinção de [nasal]}

As consoantes foram codificadas novamente e, além de distinguirmos os traços de cavidade oral (o ponto de C e o valor de [contínuo]), separamos também as consoantes nasais. Os fatores estão apresentadas abaixo:

1. duas consoantes coronais orais [-contínuo];

2. duas consoantes coronais orais [+contínuo];

3. duas consoantes labiais orais [-contínuo];

4. duas consoantes labiais orais [+contínuo];

5. duas consoantes dorsais; e

6. contextos com uma ou duas consoantes nasais 
Decidiu-se por analisar o comportamento das nasais porque há dois trabalhos que na literatura que tratam de queda de sílaba com nasais. No primeiro deles (cf. Tabela 2 na subseção 3.2.1) Pavezi (2006a) reporta que houve $5 \%$ de aplicação de haplologia com segmentos [nasal]. Adicionalmente, com o objetivo de verificar se há uma consoante ou vogal que favoreça a haplologia, bem como se há algum tipo de segmento que bloqueie o processo, além da análise dos dados naturalísticos, Pavezi (2006a) conduziu um estudo experimental com seis diferentes tipos de contextos com nasais, cujos resultados apresento a seguir:

Tabela 6 - Aplicações de haplologia em contextos com consoantes [nasal] no teste de Pavezi (2006a: 115)

\begin{tabular}{|c|c|c|c|c|c|}
\hline sentença & contexto & apl & $\tilde{n} A p l$ & $\%$ apl & total \\
\hline 1) A caMA MAgnífica quebrou ontem & /ma.ma/ & 4 & 16 & 20 & 20 \\
\hline 2) O tiME Mllagroso saiu vencedor & /me.mi/ & 11 & 9 & 55 & 20 \\
\hline 3) O agrônoMO MUçulmano acordou cedo & /mo.mu/ & 11 & 9 & 55 & 20 \\
\hline 4) A aluNA NAmoradeira chegou atrasada & /na.na/ & 9 & 11 & 45 & 20 \\
\hline 5) O telefoNE NIpônico dura mais & /ne.ni/ & 12 & 8 & 60 & 20 \\
\hline 6) O aluNO NUtrido aprende mais & /no.nu/ & 11 & 9 & 55 & 20 \\
\hline \multicolumn{2}{|l|}{ total } & 58 & 62 & 120 & 120 \\
\hline
\end{tabular}

Como se observa na Tabela 6 , a haplologia pode ser aplicada com quaisquer contextos com consoantes nasais, e /ne + ni/ é o mais favorável, segundo Pavezi (2006a).

A fim de verificar se há algum contexto (segmental e vocálico) que possa bloquear a queda de sílaba (ou seja, elisão silábica e haplologia), Leal (2006) conduziu um teste de (a)gramaticalidade, e verificou que:70

i) a haplologia é permitida com $/ m+m /$ e $/ n+n /$ :
$(180)$
alar(ME) MOderno
(teste)
(181)
more(NA) NERvosa
(teste)

\footnotetext{
70 Os exemplos (180)-(185) e a discussão sobre os resultados do teste estão na subseção 6.1 de Leal (2006).
} 
ii) a elisão silábica é permitida somente na sequência [oral + nasal]; em contextos [nasal + oral], há bloqueio:

$\begin{array}{llll}(182) & / \mathrm{b}+\mathrm{m} / & \text { goia(BA) MAdura } & \text { (teste) } \\ (183) & / \mathrm{t}+\mathrm{n} / & \text { consoan(TE) NAsalizada } & \text { (teste) } \\ (184) & / \mathrm{m}+\mathrm{b} / & \text { ?perfu(ME) BAcana > perf[ũba]cana } & \text { (teste) } \\ (185) \quad / \mathrm{n}+\mathrm{d} / & \text { ?pági(NA) Dlfícil > pág[idi]fícil } & \text { (teste) }\end{array}$

A partir destes resultados de Leal (2006), foi feita uma análise com um corpus naturalístico, ${ }^{71}$ em que o único contexto de haplologia com duas nasais foi de não aplicação, como apresento a seguir:

(186) É um foNE NORmal...

$(B G N)$

Com relação à elisão silábica, houve diversas ocorrências, todas de [oral + nasal] (ou seja, sequências [nasal + oral] não apareceram nas gravações), exemplificado a seguir:

(187) ...pendura(DO) NO pau-de-arara...

(ALES)

Assim, examinaremos se e de que forma as consoantes nasais podem atuar na queda de sílaba; com este objetivo de opor nasais vs. orais, decidimos por unir as coronais [nasal] e as labiais [nasal] num único fator. Não há, até onde sabemos, estudos que reportem outras diferenças que estão além do traço [vozeamento], com exceção de Pavezi (2006a) e de Leal (2006). Além disso, não há nestes trabalhos uma análise quantitativa (univariadas e multivariadas), como foi feito nesta tese.

Apresento a seguir exemplos do nosso corpus com diferenças em [nasal] nas consoantes:

71 Os exemplos (186) e (187) e a discussão sobre os resultados dos dados naturalísticos podem ser encontrados em Leal (2006) (cf. subseção 6.2). 
(188) deita(DO) NO chão

(189) não coMO POlenta

(190) va(MOS) MARcar

(191) compra uma máquiNA NOva
(J)

Exemplos como (188)-(191) entraram no fator 6 apresentada acima para contextos nasais, sem importar se a nasal está na segunda (cf. exemplo (188)) ou na primeira sílaba do contexto segmental (ver (189)) ou em ambas as sílabas (cf. (190) com nasais $/ \mathrm{m}+\mathrm{m} / \mathrm{e}$ (191) com nasais $/ n+n /)$.

Não temos uma hipótese formulada para esta variável que vá além daquela apresentada na subseção anterior - a hipótese levantada em 4.1.4.1.2 é que, por sua subespecificação, as coronais são as consoantes mais elididas -, mas o intuito é verificar como se comportam também as nasais. Ainda, o objetivo é verificar também qual das configurações de consoantes (sem colocar e colocando as nasais num fator à parte) é mais relevante para a aplicação do processo.

\subsection{Cavidade Oral das Vogais}

A última variável para o contexto segmental foi criada para observar qual é o comportamento das vogais, cujos fatores apresento a seguir:

1. duas vogais coronais

2. duas vogais dorso-labiais

3. duas vogais dorsais

4. coronal + dorsal

5. dorso-labial + dorsal

6. dorso-labial + coronal

7. coronal + dorso-labial

8. dorsal + coronal

9. dorsal + dorso-labial

Como se observa acima, houve 9 possibilidades para o contexto vocálico. Nos três primeiros, as cavidades orais das vogais são idênticas: coronal + coronal, que compreende as vogais /i/, /e/ e /ع/; dorso-labial + dorso-labial, incluindo as vogais /u/, /o/ e /o/; e dorsal + 
dorsal, contexto com duas vogais /a/. As possibilidades apresentadas em 4-9 são todas as outras combinações com vogais coronal, dorso-labial e dorsal.

De acordo com Leal (2006) (cf. subseção 3.2.1), não importam a anterioridade ou a altura na combinação dos traços das vogais do contexto segmental para a aplicação de queda de sílaba; os resultados de Pavezi (2006a) apontam que há a possibilidade de aplicação com segmentos [dorsal]. Assim, a hipótese é que, diferentemente do que afirmam Alkmim \& Gomes (1982), há variação com vogais diferentes de [+alto].

\subsection{Estrutura Silábica}

A análise de Alkmim \& Gomes (1982) para haplologia (cf. seção 3) prevê que a estrutura da sílaba sujeita à queda deve ser necessariamente CV, e não há restrições para a segunda sílaba; no entanto, encontramos na literatura casos de queda com sílabas CCV, por exemplo, como em sintagmas com den(TRO) + DE (cf. Battisti 2004, Pavezi 2006a e Leal 2006). Logo, é necessário verificar se e como a estrutura da sílaba sujeita a apagamento pode interferir na queda de sílaba.

Além de sílabas $\mathrm{CV}$, controlamos também estruturas com ataque (CCV) e coda ramificados (CVC) e sílabas com outros tipos de estruturas (neste caso, são todas as estruturas da primeira sílaba que são diferentes da estrutura da segunda sílaba), como apresentado a seguir:

1. $C V+C V$ duas sílabas simples

2. $C V C+C V C$ duas sílabas com coda ramificada

3. $\mathrm{CCV}+\mathrm{CCV}$ duas sílabas com ataque ramificado

4. $C V+$ outros sílaba simples seguida de outro tipo de estrutura

5. CVC + outros sílaba com coda seguida de outro tipo de estrutura

6. $\mathrm{CCV}+$ outros sílaba com ataque ramificado seguida de outro tipo de estrutura

7. outros + outros duas sílabas com outros tipos de estruturas (que não as de 1-6)

Exemplos de contextos com estruturas silábicas iguais são apresentados abaixo: 


$\begin{array}{llll}(192) & \text { CV + CV } & \text { beira(DA) DA pista } & \text { (F) } \\ (193) & \text { CV + CV } & \text { são bernarDO DO campo } & \text { (Q) } \\ (194) & \text { CVC + CVC } & \text { cuidando dos ne(TOS) DOS outros }{ }^{72} & \text { (m) } \\ (195) & \text { CVC + CVC } & \text { vendeMOS POR cento e oitenta mil } & \text { (d) } \\ (196) & \text { CCV + CCV } & \text { ia sem(PRE) PRA casa } & \text { (q) } \\ (197) & \text { CCV + CCV } & \text { semPRE PROcurei devolver } & \text { (g) }\end{array}$

Há variação de queda de sílaba em contextos como (192) e (193), em que as estruturas silábicas são CV, e estes casos foram codificados como apresentado no fator 1 ; em (194) e (195), também pode haver apagamento ou não aplicação do processo com estruturas que tenham coda, ${ }^{73}$ codificados como 2; da mesma forma, sílabas CCV com ataque variam, como exemplificado em (196) e (197), codificados como apresentado em 3.

A variação acontece também em contextos que tenham estruturas diferentes entre si, como demonstram os exemplos a seguir:

$\begin{array}{llll}(198) & \text { CV + outros } & \text { po(DE) DElxar } & \text { (E) } \\ (199) & \text { CV + outros } & \text { orozimBO MAIA } & \text { (M) } \\ (200) & \text { CVC + outros } & \text { ver os ami(GOS) CREscer74 } & \text { (D) } \\ (201) & \text { CVC + outros } & \text { boDAS DE prata } & (i) \\ (202) & \text { CCV + outros } & \text { o semes(TRE) TAMbém não é diferente } & (k) \\ (203) & \text { CCV + outros } & \text { cenTRO DA cidade } & \text { (V) } \\ (204) & \text { outros + outros } & \text { previdên(CIA) SOcial } & \text { (V) } \\ (205) & \text { outros + outros } & \text { winDOWS NOventa e oito } & (\mathrm{K})\end{array}$

Em (198) e (199), a primeira sílaba é CV, seguida de outros tipos de estruturas: em

\footnotetext{
72 No exemplo (194), novamente podemos observar que a morfologia pode interferir na queda de sílaba, já que /s/ de /dos/ é a 2a marca de plural no sintagma doS netoS doS outroS - assunto a ser estudado em trabalhos futuros (cf. também notas 44 e 58). Agradeço à Prof ${ }^{a}$ Dr $^{a}$ Ester Mirian Scarpa por me chamar a atenção a este tema.

73 Seguindo Wetzels $(1997,2000)$, a primeira sílaba da palavra muito foi considerada como uma CVC, já que podemos interpretar que no nível subjacente esta palavra é /muiNto/ que, na produção da fala torna-se [mũjto]. ${ }^{74}$ Cf. nota 72.
} 
(198), a segunda sílaba é um ditongo CVg que, na realização fonética, pode ser produzida com a perda do glide (é um ditongo leve), enquanto que, em (199), a segunda sílaba tem uma estrutura CVgV, ou seja, há um glide ambissilábico /maja/ entre as vogais dorsais /a/. Estes casos foram codificados como 4, em que unimos todos os contextos de sílabas simples seguidas de quaisquer outros tipos de estrutura. Os dois exemplos seguintes (200) e (201) foram codificados como 5 , ou seja, são casos em que uma sílaba com coda aparece seguida de outros tipos de estrutura: em (200), a primeira sílaba CVC está seguida de uma CCV de crescer e, em (201), de uma sílaba com estrutura simples CV. Em (202) e (203), a estrutura da primeira sílaba tem ataque ramificado, sendo que, em (202) está seguida de uma sílaba com coda nasal CVC e em (203), a estrutura da segunda sílaba é CV, sendo codificados como 6 - sílabas com coda seguida de outros tipos de estruturas. Finalmente, os casos em (204) e (205) exemplificam estruturas diferentes entre si e que não sejam CV, CVC ou CCV na primeira posição do contexto: a primeira sílaba em (204) é CVV, um hiato fonológico, e está seguida de uma sílaba simples; e em (205), a primeira sílaba é CVgC, um ditongo verdadeiro com coda, também seguida de uma sílaba com estrutura $C V$, casos que foram codificados como 7 , duas sílabas com outros tipos de estruturas - diferentes de CV, CCV e CVC. E como se pode observar, em todos estes casos (198)-(205), houve variação de queda de sílaba.

A hipótese para esta variável é que quanto mais leve for a sílaba sujeita ao apagamento, maior será a tendência à queda. Assim, se o contexto tiver ambas as sílabas com estrutura CV, a hipótese é que haja um favorecimento da queda de sílaba; por outro lado, se as sílabas sujeitas ao apagamento tiverem coda, a hipótese é que há um desfavorecimento do processo. Levantamos estas duas hipóteses com base em Alkmim \& Gomes (1982) e Collischonn (2007), já que as autoras afirmam que é somente com sílabas CV na primeira posição do contexto segmental que há possibilidade de queda de sílaba. $E$, se é importante que as sílabas sejam idênticas ou parecidas (cf. propostas da subseção 4.1.4.1.1.1), sendo ambas CV, a queda será hipoteticamente implementada mais facilmente (cf. Collischonn 2007, para quem as estruturas das sílabas que podem sofrer o processo são originalmente bem-formadas ).

Finalmente, com relação a estruturas CCV, não temos uma hipótese, mas o intuito é 
verificar como a queda de sílaba é conduzida se a sílabas sujeita à queda tiver uma consoante em segunda posição do ataque. De modo informal, a pergunta para estruturas CCV é: a segunda consoante do ataque "atrapalha" a queda de sílaba ou é inerte?

\subsection{Métrica}

Para esta variável, a hipótese que levantamos está relacionada à sequência dos acentos da primeira e da segunda palavras: o resultado de queda de sílaba deve ter uma tendência ao PAR (cf. subseção 2.2.3), ou seja, a aplicação do processo deverá fazer com que os acentos fortes e fracos se alternem. Codificamos os dados levando-se em conta o contexto de queda de sílaba, para depois observarmos se o processo otimiza ritmo do contexto analisado.

Para a primeira palavra, levamos em conta desde o acento primário até o final da palavra, considerando uma sílaba forte seguida de duas fracas [ $\mathrm{x} \cdot \bullet$ ] e uma sílaba forte seguida de uma fraca $[\mathrm{x} \cdot$ ], já que palavras com a última sílaba acentuada não foram analisadas; para a segunda palavra, observamos se a primeira sílaba portava acento primário [ $\mathrm{x}$ ], secundário [ y ], clítico [ c ] ou é fraca [ • ].

Tendo em vista a combinação de acentos da primeira e segunda palavras, nossos fatores foram:

1. $[x \cdot \bullet \bullet]$ lapso de 3 sílabas

2. [ $\mathrm{x} \cdots \# \mathrm{c}$ ] lapso de 3 sílabas (a última é um clítico)

3. $[x \cdots \# y]$ duas sílabas fracas entre um acento 1 ário e um acento $2^{\text {ário }}$

4. $[x \cdots \# x]$ duas fracas entre duas fortes

5. $[\mathrm{x} \cdot \# \cdot]$ lapso de 2 sílabas

6. [ $\mathrm{x} \cdot \# \mathrm{c}]$ lapso de 2 sílabas (a última é um clítico)

7. $\left[x \cdot \# y\right.$ ] uma sílaba fraca entre um acento 1 ário e um acento $2^{\text {ário }}$

8. $[\mathrm{x} \cdot \# \mathrm{x}]$ uma sílaba fraca entre duas sílabas fortes

A otimização do ritmo depende de como entendemos o grau de proeminência das sílabas. Se assumirmos que clíticos são tão fracos quanto sílabas fracas (não clíticas), o esperado é que as sequências $[\mathrm{x} \bullet \# \mathrm{x}],[\mathrm{x} \bullet \# \mathrm{y}],\left[\mathrm{x} \bullet \# \cdot{ }^{\prime}\right]$ e $[\mathrm{x} \bullet \# \mathrm{c}]$, ao sofrerem apagamento, tornem-se sequências ótimas ritmicamente, pois os resultados serão [ $x \cdot \# \mathrm{x}$ ], $[x \cdot \# y],[x \# \cdot][x \# c]$, respectivamente. As sequências $[x \cdots \# \cdot]$ e $[x \cdot \cdots c]$, se 
sofrerem apagamento, melhoram ritmicamente (pois ao invés de 3 sílabas fracas, passam a ter apenas 2), mas não são consideradas ótimas. Finalmente, as sequências $[x \cdot \# x]$ e $[x \cdot$ \# y ], se sofrerem a queda de sílaba, criam contextos de encontro acentual. A hipótese, neste caso, é que a queda de sílaba tenderá a ser evitada em contextos que criem encontros de acento.

Como vimos em (48) (cf. subseção 2.2.3 e referências ali citadas), assumimos a seguinte hierarquia, em que os acentos estão organizados do mais forte para o mais fraco:

(206) Hierarquia de acento:

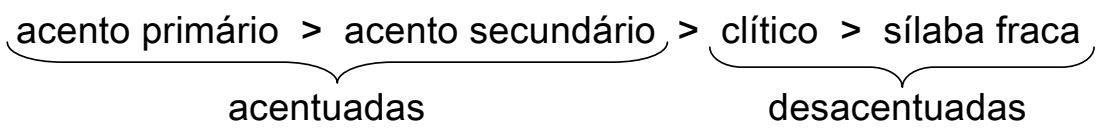

Como se vê em (206), as sílabas acentuadas podem ter dois graus de acento (primário e secundário) e sílabas sem acento podem ser clíticos ou fracas. Decidimos por identificar separadamente fracas, clíticos, secundário e primário de forma a observar se estes produzem uma distribuição diferente quando à aplicação da regra. Em outras palavras, apesar de os acentos primários e secundários serem considerados fortes, como representado em (206), primários são mais fortes do que secundários; da mesma forma, há uma hierarquia entre um clítico fonológico e uma sílaba fraca, já que aquela é mais forte do que esta.

Exemplos do corpus para esta variável são dados abaixo:

(207) $[\mathrm{x} \cdot * \# \cdot]$

na époCA CAsava

é po CA CA sa va

$\mathrm{x} \cdot \bullet \cdot \mathrm{X} \cdot$

(208) [x [ * \# c ] lógi(CO) QUE não

ló gi CO QUE

$\mathrm{X} \cdot(\cdot) \quad \mathrm{C}$

(V)

(K) 
(209) $[x \cdot \cdots \# y]$ ériCA COmeçou

(b)

é ri CA CO me çou

$x \cdot y^{\prime} \cdot x$

(210) $[x \cdot * x]$ a úni(CA) COlsa que eu não fiz

ú ni CA COI sa

$x \cdot(\cdot) \quad x \quad \bullet$

(211) $[x \cdot \# \cdot] \quad$ cheganDO DIreto da embratel

$(\mathrm{K})$

che gan DO DI re to

(212) $[x \cdot \# c] \quad$ veio chama(DA) DA unicamp

(b)

$$
\begin{array}{cccc}
\text { cha } & \text { ma } & \text { DA } & \text { DA } \\
\bullet & \mathrm{x} & (\bullet) & \mathrm{c}
\end{array}
$$

(213) $[\mathrm{x} \cdot \# \mathrm{y}] \quad$ uMA MAravilha

(n)

$\begin{array}{cccccc}\text { u } & \text { MA } & \text { MA } & \text { ra } & \text { vi } & \text { lha } \\ \mathrm{x} & \bullet & \mathrm{x} & \bullet & \mathrm{y} & \bullet\end{array}$

(214) $[x \cdot \# x]$ eles não fizeram na(DA) DIsso aí

(a)

$$
\begin{array}{cccc}
\text { na } & \text { DA } & \text { DI } & \text { sso } \\
\mathrm{x} & (\bullet) & \mathrm{x} & \bullet
\end{array}
$$

Nos exemplos (207) e (208), a expectativa é de que haja uma tendência queda de sílaba, já que sua aplicação faz com que o ritmo passe de um lapso de 3 sílabas para outro de 2 sílabas. Nestes dois casos, o resultado não é ótimo (já que duas sílabas fracas continuam adjacentes), mas a sequência rítmica melhora. As sequências métricas em (209)-(212) têm em comum lapsos acentuais de 2 sílabas. Ao ser aplicada, a queda de sílaba torna as sequências ótimas: em (209), [ x • • \# y ] > [ [ $x \cdot \# x$ ], ou seja, fica uma fraca entre duas sílabas com acento (secundário em (209) e primário em (210)). Para os casos em (211) e (212), se houver aplicação do processo, o resultado é um ritmo ótimo, em que $[\mathrm{x} \cdot \# \cdot]>[\mathrm{x} \bullet \# \cdot]$ (ver exemplo $(211))$ e $[\mathrm{x} \cdot \# \mathrm{c}]>$ [ x • \# c ] (cf. (212)), ou seja, a expectativa é também de tendência à queda de sílaba. Os contextos métricos (originais) em (213) e (214) são ótimos e aplicar a queda de sílaba 
significa ir de encontro à otimização, uma vez que a implementação do processo acarreta choque acentual. Em casos como (213) e (214), a hipótese é que a queda de sílaba seja desfavorecida.

\subsection{Prosódia}

Como foi visto na seção 3 sobre a literatura de queda de sílaba, os resultados de Tenani (2003), Pavezi (2006a) e Leal (2006) ${ }^{75}$ apontam que não há um nível prosódico que bloqueie a queda de sílaba. Segundo Battisti (2004) e Pavezi (2006a), dentro de frase fonológica e entre frases fonológicas são os ambientes mais favoráveis à aplicação de haplologia; já Leal (2006) argumenta que, tanto para a elisão silábica quanto para a haplologia, há uma maior aplicação dentro de frase fonológica reestruturada. Finalmente, Tenani (2003) afirma que a aplicação de haplologia se dá de modo inversamente proporcional aos níveis prosódicos mais altos.

Com base nesses resultados, levantamos duas hipóteses para esta variável: primeiro, não há um nível sem variação de queda de sílaba, já que nenhum deles bloqueia o processo; em segundo lugar, há uma maior propensão ao apagamento entre frases fonológicas.

Com relação aos resultados de Tenani (2002), nos quais há uma maior tendência se os níveis prosódicos forem mais baixos, não temos uma hipótese, uma vez que os resultados de Pavezi (2006a) e Leal (2006) não corroboraram os de Tenani (2002). No entanto, verificamos se isto acontece nos dados do presente trabalho.

No que concerne à queda de sílaba no nível da palavra fonológica, observe o exemplo abaixo:

(215) $\quad[\text { TE }]_{\omega}[\text { TElefonou }]_{\omega}$

Em te telefonou, a sequência /te + te/ é, segmentalmente, um contexto de queda de

75 O nível estudado por Battisti (2004) foi dentro de frase fonológica; Tenani (2002) analisou dentro frase fonológica, entre frases fonológicas, entre frases entonacionais e entre enunciados; e Pavezi (2006a) trabalhou com contextos dentro frase fonológica, entre frases fonológicas, dentro de frase entonacional, entre frases entonacionais, dentro de enunciado e entre enunciados (cf. 3.2.3). 
sílaba, já que as sílabas são idênticas. No entanto, se a primeira sílaba é um clítico fonológico, só há um sílaba; isto significa que, se houver a implementação do processo, toda a palavra deve ser apagada, o pronome te. Em casos como estes, seguimos as propostas de Veloso (2003) e Pavezi (2006a), para quem contextos em que a primeira palavra é um monomorfema, o apagamento é bloqueado (cf. também subseção 4.1.2):

(216) TE TElefonou > *(TE) TElefonou

Assim, casos em que o contexto segmental está entre palavras fonológicas foram desconsiderados, e a condição seguida neste trabalho é que a primeira palavra seja, no mínimo, um dissílabo:

$\begin{array}{llll}(217) & {\left[[\mathrm{UM}]_{\omega}[\mathrm{MEnino}]_{\omega}\right] \mathrm{c}} & > & *(\mathrm{UM}) \text { MEnino } \\ (218) & {\left[[\mathrm{UMA}]_{\omega}\right]_{c}\left[[\mathrm{MEnina}]_{\omega}\right] \mathrm{c}} & > & \mathrm{u}(\mathrm{MA}) \text { MEnina }\end{array}$

Em (217), os itens um e menino são duas palavras fonológicas, já que carregam acento primário (no nível da palavra fonológica). ${ }^{76} \mathrm{~A}$ primeira palavra um é um clítico fonológico, que deve se associar ao seu núcleo, uma palavra fonológica independente - isto é, não clítica (cf. algoritmos apresentados na subseção 2.2.4) - para formar o grupo clítico um menino. Diferentemente, em (218), há duas palavras fonológicas independentes (não clíticas) que, além de receberem acento primário (no nível da palavra fonológica), carregam acento também no nível de grupo clítico, formando dois constituintes independentes neste nível. Neste caso, a queda de sílaba pode ser aplicada. Comparando os ambientes prosódicos em (217) e (218), verificamos que o nível mais baixo da hierarquia para a aplicação de queda de sílaba é a fronteira de grupos clíticos.

Os fatores frase entonacional, frase fonológica e grupo clítico desta variável indicam fronteiras de constituintes, enquanto que, em frase fonológica reestruturada, o processo

\footnotetext{
76 Nespor \& Vogel (1986: 145) explicam que os clíticos têm uma natureza híbrida, com características externas de justaposição e propriedades internas de elementos independentes; é uma forma que se assemelha a uma palavra, mas que não pode aparecer sozinha num enunciado normal.
} 
ocorre dentro deste constituinte e a fronteira é de grupo clítico. As palavras do contexto de queda dentro e da em (57) que estão dentro do nível de frase fonológica reestruturada estão entre grupos clíticos. Em outras palavras, podemos unir as ocorrências dos níveis de frase fonológica reestruturada e de grupo clítico porque os contextos são os mesmos.

Assim, os níveis analisados no presente trabalho foram frase entonacional, frase fonológica e grupo clítico, com os seguintes fatores:

1. entre frases entonacionais

2. entre frase fonológica

3. entre grupos clíticos (e dentro de frase fonológica reestruturada)

Exemplificando, temos:

(219) cinco par(TES). $]_{\mathrm{I}}$ [ TUdo rosa

(220) você ia respondenDO.] [ [DEpois, ela dava nota

(221) para depois vir para a cida(DE) $]_{\Phi}[\mathrm{DE}$ novo

(222) tô descansanDO $]_{\Phi}[\mathrm{DO}$ meu último livro

(223) foi do la(DO)]c [DO prefeito, né?

(224) ela ficou gostanDO] c [DO espanhol

Os contextos de queda de sílaba em (219)/tes + tu/ e em (220) /do + de/ estão entre sentenças; em (221) e (222), há limites de frase fonológica entre os contextos /de + de/ e /do + do/; e em (223) e (224) o nível prosódico entre as palavras lado e do (cf. (223)) e gostando e do (224) é o de grupo clítico. E há variação na aplicação nos três níveis prosódicos, como se vê nos exemplos.

\subsection{Número de Sílabas}

O tamanho fonológico tem uma papel importante na aplicação de regras fonológicas, como apontam Nespor \& Vogel (1986: 41-46). Um dos processos fonológicos apresentados pelas autoras é o de aspiração de plosivas desvozeadas intervocálicas no italiano (a regra Georgia Toscana, cf. Nespor \& Vogel 1986: 42-44), em que há uma tendência a ser 
aplicado em constituintes pequenos. Outro trabalho que aponta a relevância do tamanho fonológico é Tenani (2002), segundo quem o tamanho do enunciado influencia na aplicação da haplologia na hierarquia prosódica: enunciados maiores tendem à aplicação do processo.

Com base nestas análises, procuramos verificar se o tamanho da palavra sujeita à queda interfere na aplicação do processo. A extensão da palavra foi contada a partir de suas sílabas, uma vez que o processo em estudo é silábico. Observe os exemplos abaixo:

(225) O que que tá acontecen(DO), NÉ? ... porque mamãe tinha meDO, NÉ?

O contexto segmental nos dois exemplos apresentados em (225) e (226) são o mesmo /do + ne/, mas a hipótese é que a probabilidade de queda de sílaba ser aplicada é maior no primeiro exemplo, já que acontecendo possui 5 sílabas e medo tem somente 2.

Vale ressaltar que o Número de Sílabas foi contado dentro da palavra fonológica: a palavra desfavoravelmente, por exemplo, possui 2 acentos, ou seja, 2 palavras fonológicas ([desfavoravel] $]_{\omega}$ e [mente] $]_{\omega}$ ); então, contam-se 2 sílabas /meN.te/ se esta palavra estiver na primeira posição do contexto de queda; se ocupar a segunda posição, contam-se 5 sílabas /des.fa.vo.ra.vel/.

Apresento abaixo os fatores:

1. 2 sílabas

2. 3 sílabas

3. 4 sílabas ou mais

Finalmente, outro fator importante é contar sílabas da primeira e não da segunda palavra, já que esta continua inteira depois do processo. 


\subsection{Frequência de Uso de Palavras}

Observe os exemplos hipotéticos a seguir, em que os contextos segmentais de queda de sílaba são iguais: ${ }^{77}$

cenTRO DO caos $>$ cen(TRO) DO caos

coenTRO DO caldo > coen(TRO) DO caldo

Nos exemplos (227) e (228), o contexto segmental é o mesmo, /tro + do/. A hipótese para esta variável é que haja uma maior propensão à queda de sílaba em (227), já que e a palavra sujeita ao apagamento centro é mais frequente do que coentro, apresentada em (228).

Num estudo sobre frequência, devemos primeiramente definir se é importante analisar a frequência de type ou a frequência de token, definidas do seguinte modo em Cristófaro \& Oliveira (2004: 657):

Frequência de tipo (type frequency) refere-se à frequência de um padrão particular no léxico (ou dicionário). Frequência de ocorrência (token frequency) refere-se à frequência de uma determinada unidade, usualmente uma palavra, em um determinado corpus (oral ou escrito).

Decidimos por analisar a relação entre a queda de sílaba e a frequência de tokens (em oposição à de types) pois este tipo de análise nos permite capturar melhor o fato de uma palavra ser ou não sujeita à queda, a depender de sua frequência. Por exemplo, na seção 5.1.1, veremos que muitos dos itens lexicais em que houve apagamento independentemente de ponto de $\mathrm{C}$ e contínuo eram itens no diminutivo, e suas contrapartes em grau normal não sofriam este apagamento. Se estivéssemos analisando os types, esta informação seria perdida, já que o diminutivo seria contado juntamente com os graus normal e aumentativo para fins de frequência.

Com o método de contagem de frequência definido (tokens), um problema que se coloca é que o número de ocorrências no nosso corpus (5628) é muito pequeno se

\footnotetext{
77 Agradeço ao Prof Dr Jairo Nunes por me apontar as possibilidades e os exemplos a seguir.
} 
considerarmos a língua portuguesa como um todo. A decisão foi utilizar as frequências de tokens do ASPA ${ }^{78,79}$ porque este tem um maior número de tokens do que o nosso, ${ }^{80}$ o que pode estar mais próximo de representar as frequências do português como um todo.

Estabelecemos 3 fatores nesta variável: cada uma das 3 faixas representam palavras de alta, média e baixa frequências de uso. O cálculo para se delimitar os três fatores foi feito seguindo-se a metodologia empregada em Françozo et al. (2002) que, analisando um corpus com aproximadamente 1 bilhão e 420 milhões de ocorrências de palavras, estabeleceu as seguintes faixas de frequência:

1) Palavras muito frequentes mais de 100 ocorrências por milhão

2) Palavras pouco frequentes entre 5 e 50 ocorrências por milhão

3) Palavras raras menos de 1 ocorrência por milhão

O corpus do projeto Avaliação Sonora do Português Atual (ASPA) tem 607.392 types, de um total de 228.766.402 tokens. Assim, nas três faixas de frequências calculadas por Françozo et al. (2002), os fatores para Frequência de Uso de Palavras encontradas no nosso corpus foram:

1. alta mais de 20.900 ocorrências no corpus ASPA

2. média de 10.451 a 20.899 ocorrências no corpus ASPA

3. baixa menos de 10.450 ocorrências no corpus ASPA

\footnotetext{
78 O projeto ASPA foi elaborado por Thais Cristófaro-Silva, em parceria com Leonardo Almeida (CPDEE-UFMG), Raquel Fontes-Martins (Poslin-FALE-UFMG), César Reis (Labfon-FALE-UFMG), Hani Camille Yehia (CefalaDELT-UFMG), Rafael Laboissiere (MaxPlank Institute-Germany) e Tony Sardinha (PUCSP). Cf. site do projeto http://www.projetoaspa.org/.

${ }^{79}$ Agradeço à Prof $^{a}$ Dr $^{a}$ Thaïs Cristófaro Silva por nos fornecer o acesso ao buscador de frequência do corpus ASPA.

80 Nas entrevistas, buscamos o vernáculo (cf. nota 52), mas os temas são limitados: mesmo que o informante falasse livremente e desviasse dos temas principais, sem a intervenção do documentador - como diversas vezes ocorreu -, há uma delimitação temática geral que tem como consequência delimitar também as palavras enunciadas. Como explicam Guy \& Zilles (2007: 115), um corpus é "parte do discurso de pessoas em interação e que a interpretação de quaisquer resultados deveria levar isso em conta em lugar de abstraí-lo completamente." Exemplificando, a palavra martelo, que é comum, nunca apareceu no corpus; por outro lado, o nome computador foi uma palavra muito frequente na fala do informante $K$, já que este capivariano é um programador.
} 
Houve 90 tokens que não entraram nesta variável, totalizando 5538 dados analisados. As exclusões são neologismos (como aborrescente), nomes próprios (Windows, Zepe), derivados de nomes próprios (capivariana) e algumas palavras em inglês (diesel, diet). Não há também entradas para 2 palavras (são paulino). Há frequências para a maioria dos nomes próprios (como Campinas, Roberto, Diego) e estes entraram na contagem.

A hipótese para esta variável é que a tendência de aplicação da queda de sílaba é diretamente proporcional à produtividade da palavra sujeita ao apagamento, ou seja, palavras de alta frequência tendem à aplicação do processo.

\subsubsection{Os grupos de fatores sociais}

Optamos por verificar o comportamento de 5 variáveis extralinguísticas, a fim de tornar completa a metodologia laboviana empregada, como explicam Mollica \& Roncarati (2001: 48):

(...) a inclusão de parâmetros sociais, tal como proposto no modelo laboviano, propicia delineamento de perfil social do falante e de pressões a que está submetido.

As variáveis externas controladas (Escolaridade, Gênero, Faixa Etária e Cidade) foram a base para se delimitar a amostra, de onde obtivemos os dados (cf. subseção 4.1.2 deste capítulo).

Battisti (2004) explica que utilizou o corpus VARSUL (24 informantes de Porto Alegre), todos com nível superior de escolaridade, para analisar a haplologia. Optamos por verificar a relação entre a queda de sílaba e Escolaridade (ver 4.1.4.2.1), Gênero (em 4.1.4.2.2), Faixa Etária (cf. 4.1.4.2.3), Informantes (cf. subseção 4.1.4.2.4) e Cidade (ver 4.1.4.2.5), que são discutidas nas subseções a seguir.

\subsection{Escolaridade}

Em seu trabalho sobre haplologia, Battisti (2004) controlou a Escolaridade de modo a utilizar entrevistas em que todos os informantes tivessem nível superior. Assim, decidimos por verificar a atuação da Escolaridade na variável dependente, cujos fatores foram: 
1. até $8^{\mathrm{a}}$ série

2. superior

Esta variável é importante na medida em que pode servir de base para demonstrar o valor (social) associado à variável dependente, como explicam Schwindt et al (2007):

(...) o nível de escolarização correlaciona-se positivamente com a aderência às formas características da variante padrão da língua.

A partir da afirmação de Schwindt et al (2007), a expectativa é que haja uma diferença nos dois grupos. Se houver, o que ocorrer com o fator de maior estudo é indício de que esta regra pode ser entendida como padrão.

\subsection{Gênero}

Assim como para a variável Escolaridade, a variável Gênero pode fornecer pistas de a variável dependente ser ou não padrão, como explica Labov (1990):

Principle I. For stable sociolinguistic variables, men use a higher frequency of nonstandard forms than women. (p. 210)

Principle la. In change from above, women favor the incoming prestige forms more than men. (p. 213)

Principle II. In change from below, women are most often the innovators. (p. 215)

De acordo com o Princípio I, homens usam uma frequência mais alta de formas não padrão do que as mulheres em variáveis sociolinguísticas estáveis. A partir do Princípio la, temos que, se as mudanças partem da classe social mais alta, mulheres favorecem as formas inovadoras (incoming) mais do que os homens. Com relação ao Princípio II, se as mudanças são da classe social mais baixa, as mulheres são frequentemente as mais inovadoras. Assim, em linhas gerais, para Labov (1990), homens tendem a usar mais a variante não padrão do que as mulheres.

Novamente, não temos uma hipótese, mas observaremos o comportamento da variável Gênero e a queda de sílaba. Da mesma forma que para Escolaridade, os resultados destes fatores podem ser pistas de a queda de sílaba ser ou não uma regra 
padrão.

\subsection{Faixa Etária}

Decidimos por analisar como a queda de sílaba se relaciona com Faixa Etária, com os seguintes fatores:

1. de 20 a 35 anos

2. mais de 50 anos $^{81}$

Estas duas faixas foram definidas principalmente de acordo com a inserção do falante no mercado de trabalho: o fator 1 representa uma população ou que está entrando no mercado de trabalho ou já está dentro dele, e o fator 2 representa pessoas que estão saindo do mercado de trabalho. Por essa razão, pessoas de 20 a 35 anos "estariam mais atentos às variantes valorizadas socialmente" (Pagotto 2004), enquanto que falantes de 50 anos não estariam tão preocupados com a norma padrão.

Não temos uma hipótese para esta variável, mas o intuito é verificar de que forma capivarianos e campineiros nas faixas de 20-35 anos e os mais velhos, com mais de 50 anos, implementam a queda de sílaba. Em outras palavras, se houver uma diferença, isto pode ser pista de que mais estudos devem ser conduzidos para verificar se há uma mudança em curso.

\subsection{Informantes}

Ao rodar esta variável, o objetivo é verificar se algum indivíduo pode estar com um comportamento muito diferente dos outros e, com isso, afetar o resultado geral. São 48 fatores para os informantes, identificadas a seguir:

81 Já que dividimos os informantes em dois grupos de faixas etárias discretas, como apresentado em 1 e 2 acima (ficando um intervalo entre as 2 variantes), o intuito não é verificar mudança e tempo aparente (Labov 2001: 142). 
Tabela 7 - Os 48 informantes

\begin{tabular}{|c|c|c|c|}
\hline fator & informante & fator & informante \\
\hline 1 & a & 25 & $\mathrm{~m}$ \\
\hline 2 & $\mathrm{~b}$ & 26 & $\mathrm{n}$ \\
\hline 3 & c & 27 & o \\
\hline 4 & $d$ & 28 & $s$ \\
\hline 5 & e & 29 & $\mathrm{t}$ \\
\hline 6 & $f$ & 30 & $\mathrm{u}$ \\
\hline 7 & g & 31 & $\mathrm{p}$ \\
\hline 8 & $\mathrm{~h}$ & 32 & $q$ \\
\hline 9 & i & 33 & $r$ \\
\hline 10 & j & 34 & $\mathrm{v}$ \\
\hline 11 & $\mathrm{k}$ & 35 & $x$ \\
\hline 12 & I & 36 & z \\
\hline 13 & $A$ & 37 & $M$ \\
\hline 14 & B & 38 & $\mathrm{~N}$ \\
\hline 15 & C & 39 & 0 \\
\hline 16 & D & 40 & $S$ \\
\hline 17 & E & 41 & $T$ \\
\hline 18 & $\mathrm{~F}$ & 42 & $U$ \\
\hline 19 & G & 43 & $P$ \\
\hline 20 & $\mathrm{H}$ & 44 & $Q$ \\
\hline 21 & 1 & 45 & $\mathrm{R}$ \\
\hline 22 & $J$ & 46 & V \\
\hline 23 & K & 47 & $x$ \\
\hline 24 & $\mathrm{~L}$ & 48 & Z \\
\hline
\end{tabular}

Controlar os informantes nos permite observar se algum deles teve um comportamento que desvie do padrão esperado. Em outras palavras, falantes que tiveram uma taxa de aplicação polarizada (um favorecimento ou um desfavorecimento excessivos, que escapem à regra geral) foram considerados como desviantes, com um comportamento que provém de uma peculiaridade do indivíduo. 


\subsection{Cidade}

Apesar de apresentarmos esta variável por último, o efeito das cidades na queda de sílaba é muito importante, pois, como vimos no capítulo 3, os resultados de Leal (2006) apontam que o contexto segmental de aplicação de queda de sílaba em Capivari ocorre em mais contextos do que em outras cidades brasileiras (cf. o dialeto de Porto Alegre, analisado em Battisti 2004; dialeto de São José do Rio Preto em Tenani 2002, 2003, 2006; comparação dos dialetos de São Paulo e São José do Rio Preto, por Pavezi 2006a; "dialetos populares", em Bisol 2000; e, finalmente, Alkmim \& Gomes 1982, que não especificam o dialeto com que trabalham).

No presente trabalho, os fatores para Cidade são:

1. Capivari

2. Campinas

A hipótese para a variável Cidade é que, se há uma maior possibilidade de contextos de queda de sílaba em Capivari, é nesta cidade em que teremos uma maior aplicação de queda de sílaba.

\subsubsection{Sumário do envelope}

Nesta subseção, apresento o quadro resumido do envelope de variação com que trabalhamos: 
Tabela 8 - Sumário do envelope de variação

\begin{tabular}{|c|c|c|c|}
\hline & variáveis & símbolos & fatores \\
\hline \multirow{34}{*}{ linguísticas } & \multirow{7}{*}{$\begin{array}{l}\text { Igualdade de } \\
\text { Segmentos }\end{array}$} & $\mathrm{C}=\mathrm{V}=$ & Cs e Vs completamente iguais \\
\hline & & $\mathrm{C}=\mathrm{V} \#$ & Cs iguais, Vs diferentes \\
\hline & & C\#vozV= & Cs diferentes em [voz], Vs iguais \\
\hline & & C\#vozV\# & Cs diferentes em [voz], Vs diferentes \\
\hline & & C\#nasalV= & Cs diferentes em [nasal], Vs iguais \\
\hline & & C\#nasalV\# & Cs diferentes em [nasal], Vs diferentes \\
\hline & & C\#distr. & Cs diferentes em [ant., distr.] \\
\hline & \multirow{5}{*}{$\begin{array}{l}\text { Cavidade Oral } \\
\text { das Consoantes }\end{array}$} & $t+t$ & 2 coronais [-contínuo] \\
\hline & & $s+s$ & 2 coronais [+contínuo] \\
\hline & & $p+p$ & 2 labiais [-contínuo] \\
\hline & & $f+f$ & 2 labiais [+contínuo] \\
\hline & & $k+k$ & 2 dorsais \\
\hline & \multirow{6}{*}{$\begin{array}{c}\text { Cavidade Oral das } \\
\text { Consoantes com } \\
\text { [nasal] }\end{array}$} & $t+t$ & 2 coronais [-contínuo] \\
\hline & & $s+s$ & 2 coronais [+contínuo] \\
\hline & & $p+p$ & 2 labiais [-contínuo] \\
\hline & & $f+f$ & 2 labiais [+contínuo] \\
\hline & & $k+k$ & 2 dorsais \\
\hline & & $n+n$ & nasais $(/ \mathrm{m} /, / \mathrm{n} /)$ \\
\hline & \multirow{9}{*}{$\begin{array}{l}\text { Cavidade Oral } \\
\text { das Vogais }\end{array}$} & ee & coronal + coronal \\
\hline & & o० & dorso-labial + dorso-labial \\
\hline & & aa & dorsal + dorsal \\
\hline & & ea & coronal + dorsal \\
\hline & & oa & dorso-labial + dorsal \\
\hline & & oe & dorso-labial + coronal \\
\hline & & eo & coronal + dorso-labial \\
\hline & & ae & dorsal + coronal \\
\hline & & ao & dorsal + dorso-labial \\
\hline & \multirow{7}{*}{ Estrutura Silábica } & $C V+C V$ & duas sílabas simples \\
\hline & & $\mathrm{CV}+\mathrm{O}$ & sílaba simples + outras estruturas \\
\hline & & $\mathrm{CCV}+\mathrm{CCV}$ & duas sílabas com ataque ramificado \\
\hline & & $\mathrm{CCV}+\mathrm{O}$ & $\begin{array}{c}\text { sílaba com ataque ramificado + outras } \\
\text { estruturas }\end{array}$ \\
\hline & & $\mathrm{CVC}+\mathrm{CVC}$ & duas sílabas com coda ramificada \\
\hline & & $\mathrm{CVC}+\mathrm{O}$ & sílaba com coda + outras estruturas \\
\hline & & $0+0$ & duas sílabas com + outras estruturas \\
\hline
\end{tabular}




\begin{tabular}{|c|c|c|c|}
\hline & \multirow{8}{*}{ Métrica } & $x \cdot \cdots \#$ & lapso de 3 sílabas \\
\hline & & $x \cdot \bullet \# c$ & lapso de 3 sílabas (a última é um clítico) \\
\hline & & $x \cdots \# y$ & $\begin{array}{c}\text { duas sílabas fracas entre um acento } 1 \text { ário e um } \\
\text { acento } 2^{\text {ário }}\end{array}$ \\
\hline & & $x \cdot \bullet \# x$ & duas fracas entre duas fortes \\
\hline & & $x \cdot \# \cdot$ & lapso de 2 sílabas \\
\hline & & $x \cdot \# c$ & lapso de 2 sílabas (a última é um clítico) \\
\hline & & $x \cdot \# y$ & $\begin{array}{l}\text { uma sílaba fraca entre um acento } 1 \text { ário e um } \\
\text { acento } 2 \text { ário }\end{array}$ \\
\hline & & $x \cdot \# x$ & uma sílaba fraca entre duas sílabas fortes \\
\hline & \multirow{3}{*}{ Prosódia } & entre Is & entre frases entonacionais \\
\hline & & entre $\Phi s$ & entre frases fonológicas \\
\hline & & $\begin{array}{l}\text { entre Cs } \\
(\Phi r)\end{array}$ & entre grupos clíticos, $\Phi$ s reestr \\
\hline & \multirow{3}{*}{ Número de Sílabas } & $2 \sigma s$ & 2 sílabas \\
\hline & & $3 \sigma s$ & 3 sílabas \\
\hline & & $\begin{array}{c}4 \text { os ou } \\
\text { mais }\end{array}$ & 4 sílabas ou mais \\
\hline & \multirow{3}{*}{$\begin{array}{l}\text { Frequência de } \\
\text { Uso de Palavras }\end{array}$} & alta & mais de 20.900 (no ASPA) \\
\hline & & média & de 10.451 a 20.899 (no ASPA) \\
\hline & & baixa & menos de 10.450 (no ASPA) \\
\hline \multirow{8}{*}{ sociais } & \multirow{2}{*}{ Cidade } & capi & Capivari \\
\hline & & camp & Campinas \\
\hline & \multirow{2}{*}{ Escolaridade } & fund & ensino fundamental \\
\hline & & sup & ensino superior \\
\hline & \multirow{2}{*}{ Gênero } & masc & masculino \\
\hline & & fem & feminino \\
\hline & \multirow{2}{*}{ Faixa etária } & $20-35$ & de 20 a 35 anos \\
\hline & & 50 & mais de 50 anos \\
\hline
\end{tabular}




\section{CAPÍTULO V}

\section{Resultados gerais}

Neste capítulo, apresento, primeiramente, os resultados encontrados no estudo piloto deste trabalho (ver 5.1), que foi a base para a codificação definitiva. Em seguida (cf. subseção 5.2), estão a distribuição geral dos dados e a descrição de como foram computados; finalmente, apresento os resultados de queda de sílaba em que as duas cidades foram rodadas juntas (ver 5.3).

\subsection{O estudo piloto}

Encontramos muitos estudos sobre a haplologia, tanto para o português brasileiro quanto para outras línguas (cf. referências citadas no capítulo 3), e estes indicam que o contexto segmental da regra é aquele que tem consoantes iguais ou que diferem, no máximo, em vozeamento. Os trabalhos de Leal $(2006,2007)$ (cf. subseção 3.3) constataram que há outras possibilidades de aplicação de queda de sílaba, em que as consoantes podem diferir além de vozeamento. No entanto, não há, até onde sabemos, um estudo que verifique quais são estas possibilidades utilizando-se ferramentas quantitativas.

Assim, numa primeira aproximação aos dados, decidimos por fazer um estudo piloto, cujo objetivo foi verificar todas as possíveis combinações segmentais de queda de sílaba, mesmo aquelas que não tenham sido, por acaso, encontradas em Leal $(2006,2007)$. Em outras palavras, a fim de comprovar onde há pouca ou nenhuma variação, buscamos no piloto tanto os dados categóricos quanto aqueles com aplicação/não aplicação de queda de sílaba, quantificando as variações do processo de acordo com a Cavidade Oral das Consoantes (ponto de C e o valor para [contínuo]).

Nesta primeira análise, foram codificados dados de 3 entrevistas do corpus, desprezando-se os 10 primeiros minutos da gravação até 1 hora, com os seguintes informantes:82

82 Todas as rodadas do presente trabalho foram feitas com o programa GoldVarb X, versão 3.0b3 (cf. Sankoff, 
Tabela 9 - Informantes utilizados na primeira análise

\begin{tabular}{|c|c|c|c|c|}
\hline Informante & Cidade & Escolaridade & Gênero & Faixa etária \\
\hline a & Capivari & & & \\
\cline { 1 - 2 } b & Capivari & ensino fundamental & feminino & mais de 50 anos \\
\hline$m$ & Campinas & & & \\
\hline
\end{tabular}

A escolha dos 3 informantes foi feita de acordo com a ordem em que os informantes foram sendo gravados, ou seja, a mais aleatória possível. Exemplifico abaixo como foi feita a coleta dos dados. Por exemplo, da sentença a seguir:

(229) A gente ficava lá em frente da casa

(a)

foram coletados os seguintes tokens:

$\begin{array}{llll}\text { (230) } & \text { 10 token: } & \text { genTE Flcava } & \text { /te }+\mathrm{fi} / \\ \text { (231) } & 2^{\circ} \text { token: } & \text { ficaVA LÁ } & \text { /va }+ \text { la/ } \\ \text { (232) } & 3^{\circ} \text { token: } & \text { fren(TE) DA } & \text { /te }+ \text { da/ }\end{array}$

No primeiro token apresentado em (230), o contexto consonantal /t $+\mathrm{f} /$ é uma coronal [-contínuo] seguida de uma labial [+contínuo], ou seja tanto o ponto de C quanto [contínuo] são diferentes; em (231), ambas as consoantes /v + I/ são [+contínuo], mas o ponto de $C$ difere (é uma labial seguida de uma coronal); finalmente, no contexto $/ t+d / e m$ (232), há igualdade tanto no ponto de C (são duas coronais) como no traço [-contínuo]. De acordo com os resultados de Leal (2006), a única possibilidade de aplicação de queda de sílaba é (232), já que as coronais (mesmo ponto de C) possuem o traço [-contínuo]. De fato, não houve queda de sílaba em (230) e (231), somente em (232). No entanto, não há como saber, até aqui, se os contextos (230) e (231) são não aplicações de queda de sílaba ou se são contextos em que nunca há apagamento - dados categóricos. E é neste ponto que vemos a valia da primeira análise: retirar os contextos em que há bloqueio de queda de sílaba, computando, numa segunda análise, somente os casos de variação do processo. 
Com um total de 4024 tokens, o resultado geral apresentado a seguir corresponde a todos os quatro possíveis contextos de traços internos às consoantes: ${ }^{83,84}$

Tabela 10 - Frequências das consoantes segundo as cavidades orais

\begin{tabular}{|c|c|c|c|}
\hline \multicolumn{1}{|c|}{ Cavidade Oral das Consoantes } & N & N total & \%apl \\
\hline a) ponto de C igual, [contínuo] igual & 121 & 909 & 13,3 \\
\hline b) ponto de C igual, [contínuo] diferente & 27 & 881 & 3,1 \\
\hline c) ponto de C diferente, [contínuo] igual & 21 & 1209 & 1,7 \\
\hline d) ponto de C diferente, [contínuo] diferente & 5 & 1025 & 0,5 \\
\hline Total & 174 & 4024 & 4,3 \\
\hline
\end{tabular}

Podemos observar na Tabela 10 que os dados têm uma boa distribuição de ocorrências (909 dados para o contexto $a$; 881 para $b$; 1209 para a sequência $c$; e 1025 para d); entretanto, a frequência de aplicação de queda de sílaba é muito baixa: houve somente 174/4024 tokens, correspondente a apenas 4,3\% (aplicações de 121, 27, 21 e 5 tokens, para os contextos $a, b, c$ e $d$, respectivamente). ${ }^{85}$ Estes números são reveladores, pois apontam a necessidade de se fazer esta primeira análise: se, por um lado, buscamos tokens de queda de sílaba que por acaso não apareceram no corpus de Leal (2006), por outro, há diversos contextos que apresentaram resultados categóricos de não aplicação da queda de sílaba nesta primeira análise - ou seja, dados em que nunca há possibilidade de o processo ocorrer ou que a aplicação é muito baixa, quase categórica: com ponto de $\mathrm{C}$ igual e [contínuo] diferente (contexto b), a frequência é $27 / 881$, com $3,1 \%$ de aplicação de queda de sílaba; com ponto de C diferente e um mesmo valor para [contínuo] (contexto c), houve $21 / 1209$ ocorrências (1,7\% de aplicação); e a frequência é ainda mais baixa se o ponto de $\mathrm{C}$ e o valor para [contínuo] forem diferentes (contexto d), com N=5/1025 e 0,5\%.

Observamos também que a maior parte de aplicação do processo está em contextos com consoantes que têm a cavidade oral igual: de todas as 174 aplicações, 121 são de

${ }^{83} \mathrm{Cf}$. Anexo II, no qual descrevemos os contextos consonantais um a um.

84 Todos os valores de frequências e pesos relativos nas tabelas e gráficos se referem à aplicação de queda de sílaba, indicada por "apl" nas tabelas.

${ }^{85}$ A frequência de aplicação de queda de sílaba (4,3\%) apresentada na Tabela 10 está abaixo da porcentagem mínima (5\%) para a feitura de uma análise multivariada confiável. No entanto, não houve necessidade desta análise, e o objetivo do piloto foi atingido: pudemos verificar que as aplicações de queda de sílaba com consoantes diferentes em ponto de $\mathrm{C}$ e/ou [contínuo] é quase categórica. 
consoantes com um mesmo ponto de C/valor para [contínuo], o que corresponde a $69,5 \%$ das aplicações. Olhando de perto para os 53 dados restantes $(30,5 \%$ de 174 aplicações de queda de sílaba ou 1,3\% de 4024 dados), vemos que compreendem casos particulares de queda de sílaba, ou seja, são palavras específicas que, mesmo com um contexto em que as consoantes têm cavidade oral diferentes, pode haver apagamento da primeira sílaba do contexto segmental, como apresentado na próxima subseção.

\subsubsection{Casos particulares no estudo piloto}

Como vemos na Tabela 10 da subseção anterior, a maior parte de aplicação de queda de sílaba é com consoantes que têm cavidades orais iguais. No entanto, o processo acontece também com cavidades orais diferentes; são 53 tokens de 31 types, enumerados a seguir: 
Tabela 11 - Aplicações de queda de sílaba com cavidades orais das consoantes diferentes

\begin{tabular}{|c|c|c|c|c|c|}
\hline palavra & classe & frequência de uso & cidade & $\mathrm{N}$ & $\mathrm{N}$ total \\
\hline 1. falava & \multirow{4}{*}{$\begin{array}{l}\text { palavras terminadas } \\
\text { em morfema de imperfeito }\{\text {-va }\}\end{array}$} & baixa & Campinas & 2 & 17 \\
\hline 2. ficava & & baixa & Campinas & 1 & 14 \\
\hline 3. tava & & baixa & Capivari & 2 & 36 \\
\hline 4. viajava & & baixa & Campinas & 1 & 1 \\
\hline & & \multicolumn{2}{|c|}{ subtotal } & 6 & 68 \\
\hline 5. amiguinho & \multirow{12}{*}{$\begin{array}{l}\text { palavras terminadas } \\
\text { em }\{\text {-inh- }\} \text { morfológico }\end{array}$} & baixa & Campinas & 1 & 1 \\
\hline 6. amiguinhos & & baixa & Campinas & 1 & 1 \\
\hline 7. blusinha & & baixa & Campinas & 2 & 2 \\
\hline 8. cabelinho & & baixa & Campinas & 2 & 8 \\
\hline 9. carrinho & & baixa & Campinas & 1 & 2 \\
\hline 10. mochilinha & & baixa & Campinas & 1 & 5 \\
\hline 11. pequenininha & & baixa & Campinas & 1 & 1 \\
\hline 12. pertinho & & baixa & Campinas & 3 & 3 \\
\hline 13. pouquinho & & baixa & Campinas & 1 & 5 \\
\hline 14. quietinho & & baixa & Campinas & 1 & 1 \\
\hline 15. rapidinho & & baixa & Campinas & 1 & 1 \\
\hline 16. tapinha & & baixa & Campinas & 1 & 1 \\
\hline & & \multicolumn{2}{|c|}{ subtotal } & 16 & 31 \\
\hline 17. tinha & \multirow{3}{*}{$\begin{array}{l}\text { palavras terminadas } \\
\text { em /-n-/ não morfológico }\end{array}$} & alta & Campinas & 2 & 70 \\
\hline 18. banho & & baixa & Campinas & 1 & 2 \\
\hline & & \multicolumn{2}{|c|}{ subtotal } & 3 & 72 \\
\hline 19. casa & \multirow{13}{*}{ outros } & alta & Capivari & 6 & 43 \\
\hline 20. causa & & alta & Capivari & 6 & 15 \\
\hline 21. coisas & & alta & Capivari & 1 & 11 \\
\hline 22. ela & & alta & Capivari & 1 & 243 \\
\hline 23. ele & & alta & Capivari & 1 & 162 \\
\hline 24. fala & & alta & Campinas & 1 & 25 \\
\hline 25. gente & & alta & Capivari & 2 & 103 \\
\hline 26. negócio & & alta & Capivari & 2 & 3 \\
\hline 27. sabe & & alta & Campinas & 2 & 34 \\
\hline 28. tudo & & alta & Campinas & 2 & 53 \\
\hline 29. conhece & & baixa & Campinas & 1 & 3 \\
\hline 30. embaixo & & baixa & Campinas & 2 & 5 \\
\hline \multirow[t]{3}{*}{ 31. gosta } & & média & Campinas & 1 & 10 \\
\hline & & \multicolumn{2}{|c|}{ subtotal } & 28 & 710 \\
\hline & & \multicolumn{2}{|l|}{ total } & 53 & 881 \\
\hline
\end{tabular}


$\mathrm{Na}$ Tabela 11, estão os types, suas classificações, as frequências de uso (com base no ASPA), as cidades a que pertencem os informantes, os números de aplicações de queda de sílaba e os números de tokens de quantas vezes a palavra apareceu no corpus do presente trabalho. Lembramos que as variáveis Escolaridade, Gênero e Faixa Etária dos informantes são iguais: todas estudaram até o ensino fundamental série e têm mais de 50 anos (cf. Tabela 9).

Podemos observar que a maior parte de aplicações de queda de sílaba com cavidades orais das consoantes diferentes são palavras terminadas em /-n-/, tanto não morfológico (3 tokens) quanto morfológicos (16 casos); observamos também que 6 casos são com palavras terminadas em morfema de imperfeito $\{-v a\}$.

Dos 31 types apresentados na primeira coluna, 12 são palavras de alta frequência de uso: tinha, casa, causa, coisas, ela, ele, fala, gente, negócio, sabe, tudo e gosta (este último é um tipo de frequência média no corpus ASPA, mas é uma palavra muito comum). No entanto, mesmo nestes casos de palavras de alta frequência, a taxa de aplicação é muito baixa: as palavras em que o processo ocorreu mais foram casa ( 6 aplicações em 43 tokens que apareceram no corpus do estudo piloto) e causa (também 6 aplicações em 15 ocorrências da palavra). Levando-se em consideração que o total de dados foi 4024, o número de aplicações é muito baixo.

Assim, devido ao baixo número de frequência dos tokens (cf. Tabela 11) os casos particulares de queda de sílaba serão deixados para trabalhos futuros.

Uma vez que pudemos nos certificar de que a maioria dos casos de aplicação de queda de sílaba são contextos em que a Cavidade Oral das Consoantes é a mesma, foi com esses tipos de dados que trabalhamos (cf. coleta de dados na seção 4.1.2).

Na próxima subseção 5.2, apresento como foi feita a computação dos dados e quais foram as distribuições gerais obtidas e, em 5.3, estão os resultados das duas cidades computadas numa mesma rodada. 


\subsection{Distribuição geral e computação dos dados}

$\mathrm{Na}$ rodada geral, trabalhamos com 48 informantes, sendo 24 de Capivari e 24 de Campinas. No estudo piloto, foram coletados 4924 dados de 3 informantes e, no corpus definitivo, foram 5628 tokens de 48 informantes. Comparativamente, o número de dados do corpus definitivo é menor. A razão desta diminuição de dados foi porque, com os 48 informantes, computamos somente os dados em que há um mesmo ponto de $\mathrm{C}$ e valor para [contínuo] das consoantes nas produções dos informantes - assim, deixamos de lado os contextos com ponto de C igual e [contínuo] diferente, ponto de C diferente e [contínuo] igual e ponto de $C$ diferente e [contínuo] diferentes (contextos $b, c$ e $d$ apresentados na Tabela 10). A seguir, apresentamos as distribuições destes 5628 tokens:

Tabela 12 - Resultados gerais de aplicação de queda de sílaba

\begin{tabular}{|c|c|c|}
\hline GERAL & $\mathrm{N}$ & $\%$ \\
\hline aplicação & 1186 & 21,1 \\
\hline não aplicação & 4442 & 78,9 \\
\hline total & 5628 & \\
\hline
\end{tabular}

Como se observa na Tabela 12 , houve $21,1 \%$ de aplicação de queda de sílaba.

Foram feitas 5 rodadas com as variáveis apresentadas em (233) abaixo (cf. o envelope de variação na subseção 4.1.3):

(233) As variáveis linguísticas e sociais de queda de sílaba

a) variáveis linguísticas

- do contexto segmental:

1. Igualdade de Segmentos no interior das sílabas - só estruturas CV;

2. Cavidade Oral das Consoantes;

3. Cavidade Oral das Consoantes com distinção de segmentos [nasal];

4. Cavidade Oral das Vogais;

- outras variáveis (além de contexto segmental):

5. Estrutura Silábica;

6. Métrica das palavras;

7. Prosódia;

8. Número de Sílabas da palavra 1 (aquela sujeita ao apagamento);

9. Frequência de Uso da palavra 1 (aquela sujeita ao apagamento); 
b) variáveis sociais:

10. Informantes;

11. Escolaridade;

12. Gênero;

13. Faixa Etária; e

14. Cidade

Na primeira rodada, entraram todas as variáveis, ou seja, incluindo-se as 4 variáveis do contexto segmental (apresentados em 1-4 acima), as outras variáveis linguísticas e sociais (em 5-14 acima). Em seguida, foram rodadas cada uma das variáveis do contexto segmental em oposição a todas os outras variáveis (linguísticos e sociais), uma a uma. De forma resumida, temos as seguintes rodadas:

(234) Resumo das rodadas

Rodada 1: todos os grupos de contexto segmental (cf. 1-4), variáveis linguísticas listadas de 5-10 e variáveis sociais (ver 11-15);

Rodada 2: contexto segmental de Igualdade de Segmentos nas sílabas somente com estruturas CV, variáveis linguísticas (5-10) e sociais (11-15);

Rodada 3: Cavidade Oral das Consoantes no contexto segmental, variáveis linguísticas (5-10) e sociais (11-15);

Rodada 4: no contexto segmental, foram rodadas as variáveis de Cavidade Oral das Consoantes com distinção de segmentos [nasal], incluindo também as variáveis linguísticos (5-10) e sociais (11-15); e

Rodada 5: Cavidade Oral das Vogais como contexto segmental, variáveis linguísticas (5-10), sociais (11-15).

Como observamos em (234), foram 5 rodadas, diferenciadas a partir do contexto segmental. Optamos por examinar os dados do contexto segmental mais de perto (incluindo e excluindo variáveis) por ser este o modo como o processo fonológico é definido, buscando identificar quais características do contexto segmental se sobrepõem às outras (por exemplo, responder à questões como: as consoantes são mais importantes do que as 
vogais?). Uma vez que os dados foram rodados com as duas cidades juntas e também em separado, houve 3 rodadas grandes (a geral, Capivari e Campinas) e, multiplicando-se as 5 rodadas apresentadas em (234), obtivemos um total de 15 rodadas.

Das 5 rodadas feitas (para cada um dos 3 conjuntos de dados), os resultados obtidos foram muito semelhantes, variando alguns (pequenos) números. Mas o importante é que a tendência ao processo permaneceu igual em todas as rodadas: se um fator favoreceu a queda de sílaba, este mesmo fator continuou a favorecer nas outras rodadas; o mesmo comportamento foi observado se um fator desfavoreceu a queda de sílaba, ou se foi neutro: permaneceu desfavorecendo (ou ficou neutro) nas outras rodadas - as rodadas foram tão parecidas que, diversas vezes, o programa selecionou as mesmas iterações em diferentes rodadas. Para ilustrar os resultados de que todas as variáveis tiveram comportamentos semelhantes em diferentes rodadas, ${ }^{86}$ apresento os pesos relativos das variável Frequência de Uso das Palavras:

Tabela 13 - Semelhanças nos pesos relativos da variável Frequência de Uso das Palavras

\begin{tabular}{|c|c|c|c|c|c|}
\hline frequência de palavra & rodada 1 & rodada 2 & rodada 3 & rodada 4 & rodada 5 \\
\hline alta & 0,504 & 0,519 & 0,507 & 0,512 & 0,515 \\
\hline média & 0,564 & 0,549 & 0,565 & 0,565 & 0,552 \\
\hline baixa & 0,459 & 0,441 & 0,454 & 0,445 & 0,448 \\
\hline
\end{tabular}

Rodada 1: input $=0.136$ significância: $0.004 ;$ Rodada 2: input $=0.148$ significância: 0.001 ; Rodada 3: input $=0.155$ significância: 0.000 ; Rodada 4: input $=0.142$ significância: 0.001 ; Rodada 5 : input $=$ 0.147 significância: 0.001 .

Como podemos observar na tabela acima, na rodada em que todas as configurações de contexto segmental foram computadas (rodada 1), os pesos relativos para os fatores alta, média e baixa foram $p=0,504, p=0,564$ e $p=0,459$, respectivamente, ou seja, palavras de alta frequência parecem ser neutras ao processo, enquanto que palavras de frequência média tendem (levemente) à queda de sílaba e palavras de baixa frequência inibem, também levemente, o processo. $\mathrm{Na}$ rodada 2 , em que a variável de contexto segmental foi Igualdade de Segmentos, as tendências continuam iguais: alta frequência, com $p=0,519$, são neutras com relação a $p=0,549$ e $p=0,441$, de palavras de média (com

${ }^{86}$ Cf. resumo das 5 rodadas em (234), na subseção 5.2 . 
uma tendência à queda de sílaba) e baixa frequências (que desfavorece), respectivamente. Para as rodadas em que foram computados os contextos segmentais com Cavidade Oral das Consoantes (rodada 3), Cavidade Oral das Consoantes com distinção de segmentos [nasal] (rodada 4), e Cavidade Oral das Vogais (rodada 5), todas as variáveis de Frequência de Uso de Palavras tiveram o mesmo comportamento: palavras de frequência média de uso favorecem a queda de sílaba; palavras com frequência baixa inibem o processo; e o fator que representa palavras de alta frequência de uso parece ser neutro.

Para uma melhor visualização dos resultados, observe abaixo o gráfico com os pesos relativos obtidos nas 5 rodadas para a variável Frequência de Uso das Palavras:

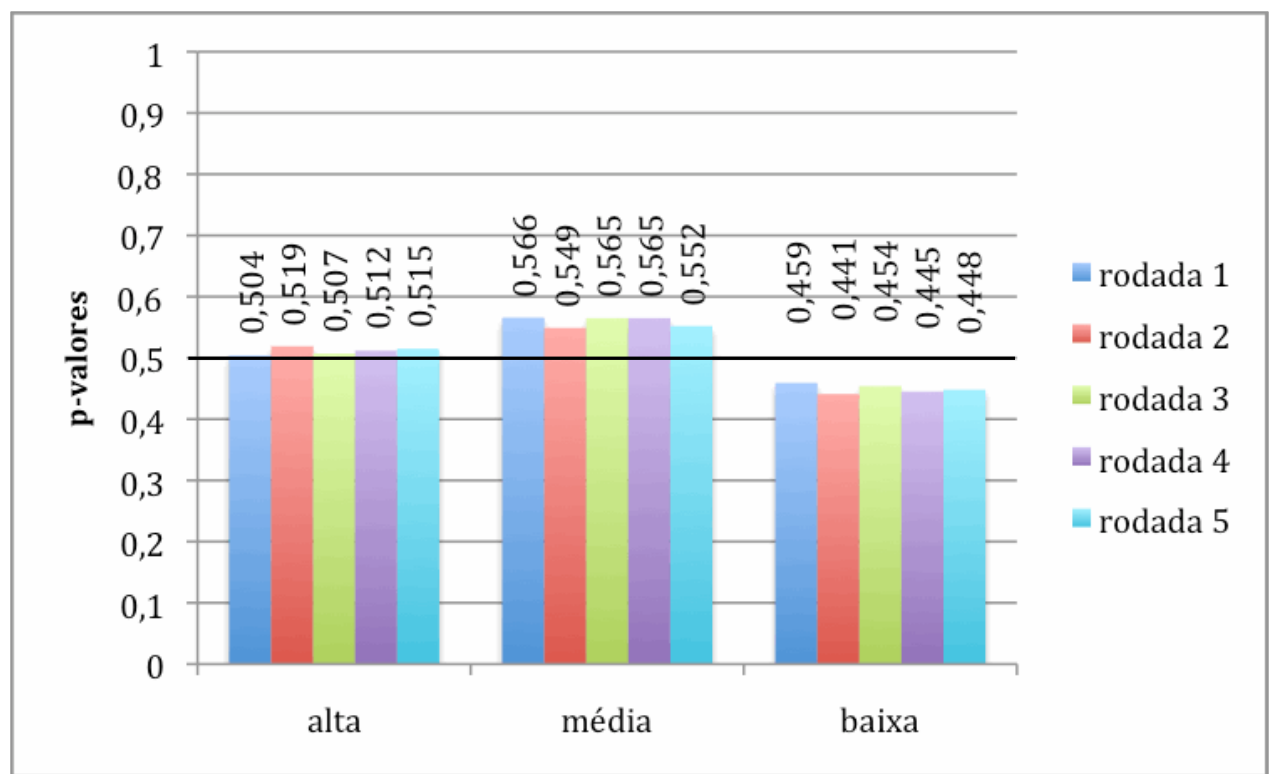

Gráfico 5 - Semelhanças nos pesos relativos da variável Frequência de Uso das Palavras

Vemos no gráfico acima que os resultados para o fator de frequência alta sempre apresentaram um peso relativo indicativo de neutralidade com relação à queda de sílaba; palavras de frequência média tendem (um pouco) ao processo; finalmente, palavras de baixa frequência inibem (levemente) o processo.

Ressalto ainda que a variável Informantes foi selecionada em todas as 5 rodadas, enquanto que nenhuma das variáveis das outras variáveis externas Escolaridade, Gênero, Faixa Etária e Cidade foi selecionado.

Assim, decidimos por apresentar os resultados das frequências e pesos relativos da 
rodada 1 , em que todas as variáveis para o contexto segmental foram rodadas.

Apresento, na próxima subseção, os resultados da rodada geral, em que Capivari e Campinas foram rodadas em conjunto.

\subsection{Resultados: as duas cidades}

Como dito na seção 5.2, nesta rodada geral aqui apresentada, todas as variáveis para o contexto segmental foram utilizadas, incluindo o restante das variáveis linguísticas e as variáveis sociais. ${ }^{87}$

A única variável (linguística) não selecionada na rodada geral foi Cavidade Oral das Consoantes sem distinguir o traço [nasal]. Assim, a Igualdade de Segmentos nas sílabas, a Cavidade Oral das Consoantes (fazendo-se distinção de segmentos [nasal]) e Cavidade Oral das Vogais são variáveis que interferem no processo. Ainda, as outras variáveis linguísticas (que não do contexto segmental) Estrutura Silábica, Métrica e Prosódia, o Número de Sílabas da primeira palavra e sua Frequência de Uso também são importantes para a aplicação da queda de sílaba nos dados de Capivari e Campinas juntas.

Se, para as variáveis linguísticas só não foi selecionado um deles, para as variáveis sociais só foi selecionada uma delas: os informantes, do que podemos interpretar que Escolaridade, Gênero, Faixa Etária e Cidade não interferem no processo.

A apresentação detalhada dos resultados da rodada geral está disposta em 2 subseções principais a seguir, as variáveis linguísticas (cf. 5.3.1) e os sociais (ver 5.3.2).

\subsubsection{As variáveis linguísticas}

Apresento nesta subseção as seguintes variáveis linguísticas que podem interferir na queda de sílaba: o contexto segmental (cf. 5.3.1.1); a Estrutura Silábica (5.3.1.2); a Métrica (5.3.1.3); a Prosódia (5.3.1.4); o Número de Sílabas da palavra sujeita ao

87 Lembramos que, para a variável de igualdade de segmentos, foram excluídas 2243 combinações de estruturas silábicas diferentes de $\mathrm{CV}$, totalizando 3385 tokens computados nesta variável. Com relação à frequência de uso das palavras, 90 tokens que não entraram, totalizando 5538 dados - cf. envelope de variação nas subseções 4.1.4.1.1.1 (Igualdade de Segmentos) e 4.1.4.1.6 (Frequência de Uso de Palavras). No que concerne à cavidade oral das consoantes, codificamos de duas formas: primeiramente, verificamos os pontos de C e os valores para [contínuo] (ou seja, a cavidade oral) de todos os tokens. Num segundo momento, codificamos também as consoantes que tivessem o traço [nasal] - cf. subseções 4.1.4.1.1.2 (cavidade oral das consoantes) e 4.1.4.1.1.3 (cavidade oral das consoantes com distinção de [nasal]). 
apagamento (cf. 5.3.1.5); e a Frequência de Uso da primeira palavra do contexto (ver 5.3.1.6).

\subsubsection{Contexto segmental}

Como vimos na subseção 4.1.4.1.1, o contexto segmental é muito importante para a queda de sílaba, pois é com ele que se define o processo (cf. em 3.2.1 a definição do contexto segmental de queda de sílaba com base na literatura). Assim, optamos por analisá-lo de diversas formas e aqui o apresentamos nas seguintes subseções: em 5.3.1.1.1, estão os resultados para a variável de Igualdade de Segmentos nas sílabas; em 5.3.1.1.2, apresentamos as variáveis relacionadas às consoantes; e em 5.3.1.1.3 apresentamos a variável das vogais.

\subsection{Igualdade de Segmentos nas Sílabas}

As frequências e pesos relativos para a variável de Igualdade de Segmentos ${ }^{88}$ são dadas a seguir: 89,90

\footnotetext{
88 Vale lembrar que, nesta variável, entraram apenas sílabas simples, ou seja, 2243 dados com sílabas diferentes de CV foram excluídos (cf. envelope em 4.1.3).

89 As frequências e pesos relativos são de aplicação de queda de sílaba, como indica a abreviação "apl" nas tabelas (cf. nota 84). Apresentamos também, depois do nome de cada variante, sua respectiva abreviação entre parênteses (abreviações que foram usadas nos gráficos. Por exemplo, os símbolos $(\mathrm{C}=, \mathrm{V}=)$ indicam "sílabas completamente iguais" Tabela 14). Finalmente, "N" e "p.r." indicam, respectivamente, "número de ocorrências" e "peso relativo".

$90 \mathrm{Na}$ Tabela 14, ao comparar a maior porcentagem e o maior peso relativo dos fatores, temos que ambos são para o fator de sílabas completamente iguais $(\mathrm{C}=\mathrm{V}=)$, com $37,6 \%$ e $p=0,576$. No entanto, o mesmo não ocorre com o segundo colocado: a segunda maior porcentagem é para o fator C\#vozV\# (consoantes diferentes em [vozeamento] e vogais diferentes), com $30,6 \%$ e seu peso relativo $(p=0,512)$ não corresponde ao segundo maior peso relativo. Este resultado pode decorrer de duas causas: (i) ou por causa da não ortogonalidade dos dados (há muitos dados em um local e muito poucos em outro); (ii) ou há interação entre grupos de fatores. Optamos por utilizar os resultados apresentados na Tabela 14, e casos como (i) e (ii) serão abordados futuramente. Agradeço ao Prof Dr Ronald Beline Mendes por me apontar esta possibilidade.
} 
Tabela 14 - Variável Igualdade de Segmentos (as duas cidades)

\begin{tabular}{|l|c|c|c|c|}
\hline \multicolumn{1}{|c|}{ Igualdade de Segmentos } & $\mathrm{N}$ & $\mathrm{N}$ total & $\%$ apl & P.R. \\
\hline бs completamente iguais (C=V=) & 94 & 250 & 37,6 & 0,576 \\
\hline Cs iguais, Vs diferentes (C=V\#) & 258 & 888 & 29,1 & 0,555 \\
\hline Cs diferentes em [vozeamento], Vs iguais (C\#vozV=) & 96 & 323 & 29,7 & 0,477 \\
\hline Cs diferentes em [vozeamento], Vs diferentes (C\#vozV\#) & 232 & 758 & 30,6 & 0,512 \\
\hline Cs diferentes em [nasal], Vs iguais (C\#nasalV=) & 20 & 154 & 13 & 0,438 \\
\hline Cs diferentes em [nasal], Vs diferentes (C\#nasalV\#) & 81 & 959 & 8,4 & 0,462 \\
\hline Cs diferentes em [anterior, distr.], Vs não importam (C\#distr.) & 2 & 53 & 3,8 & 0,148 \\
\hline \multicolumn{1}{|c|}{ total } & 783 & 3385 & 23,1 & \\
\hline
\end{tabular}

input $=0.136 ;$ significância: 0.004

Os fatores que mais favorecem a queda de sílaba são Sílabas Completamente Iguais, com $p=0,576$, e Consoantes Iguais, Vogais Diferentes, com $p=0,555$, exemplificadas a seguir: 91

$$
\begin{array}{ll}
\mathrm{C}=\mathrm{V}= & \text { apren(DE) DEsenho } \\
\mathrm{C}=\mathrm{V} \# & \text { acaba(DO) DE ficar noivo }
\end{array}
$$

Em (235) e (236), as consoantes são idênticas $/ d+d /$ e as vogais diferem no segundo exemplo (contexto vocálico $/ 0+\mathrm{e} /$ ). Em ambos os casos, há um favorecimento para a queda de sílaba, mas se as vogais forem diferentes, (cf. (236)), o favorecimento é (levemente) menor.

Se as consoantes diferirem em vozeamento, os pesos relativos estão próximos do neutro, tanto se as vogais forem iguais $(p=0,477)$ ou diferentes $(p=0,512)$, como exemplificado a seguir:

$$
\begin{array}{ll}
\text { C\#vozV }= & \text { monTE DE árvore } \\
\text { C\#vozV\# } & \text { aberTO DE sexta }
\end{array}
$$

\footnotetext{
91 Nos exemplos de cada uma das variantes, demos preferência ao ambiente de queda de sílaba, sendo que as aplicações e não aplicações foram tomadas ao acaso (lembramos que os casos de aplicação estão entre parênteses). Para exemplos das variantes que levam em conta aplicação e não aplicação do processo, cf. o envelope de variação em 4.1.4.
} 
Em (237) e (238), a primeira consoante do contexto segmental é desvozeada /t/, seguida de uma /d/ vozeada; aqui também, apesar da diferença entre as consoantes em (237) /e+e/ e em (238) /o+e/, o comportamento dos dois fatores é semelhante (os pesos relativos estão próximos ao ponto neutro).

A partir destes resultados, verificamos que o vozeamento pode interferir na queda de sílaba, diferente do resultado da literatura (ver subseção 3.2.1): se compararmos, por um lado, os pesos relativos para consoantes iguais, com $p=0,576$ (para vogais iguais) e $p=0,555$ (para vogais diferentes) e, por outro lado, consoantes que diferem em vozeamento, com $p=0,477$ (para vogais iguais) e $p=0,512$ (para vogais diferentes), podemos notar que se as consoantes forem diferentes em [vozeamento], há uma neutralidade do processo - ou seja, se não houver uma diferença entre as consoantes, o processo é favorecido enquanto que, se estes segmentos forem diferentes em [vozeamento], há uma neutralidade.

Ainda de acordo com estes resultados, as vogais parecem não interferir no processo, já que, sendo iguais ou diferentes, as tendências são parecidas: se as consoantes forem iguais, os pesos relativos são $p=0,576$ para vogais iguais e $p=0,555$ para vogais diferentes; para consoantes diferentes em [vozeamento], os pesos relativos são $p=0,477$ e $p=0,512$ (vogais iguais e diferentes, respectivamente). Estes resultados de neutralidade das vogais podem ser corroborados com consoantes diferentes no traço [nasal]: mesmo com a diferença nas vogais, estes dois contextos desfavorecem a queda de sílaba - vogais iguais $(p=0,438)$ e diferentes $(p=0,462)$. Apresento abaixo exemplos destes fatores:

$$
\begin{array}{ll}
\text { C\#nasalV= } & \text { viDA NA cidade } \\
\text { C\#nasalV\# } & \text { esperanDO NA porta }
\end{array}
$$

Para o fator em que as consoantes diferem em [anterior, distribuído], ${ }^{92}$ não podemos tirar conclusões, já que a frequência foi muito baixa, com $N=2 / 53$. Observe o exemplo

\footnotetext{
92 Lembramos que não há distinção entre vogais nesta variante em razão do pouco número de tokens desta variável: as ocorrências de consoantes que diferem em [anterior, distribuído] com vogais iguais e diferentes foram $\mathrm{N}=2 / 28$ e $\mathrm{N}=0 / 27$, respectivamente.
} 
abaixo, em que a primeira consoante é [+anterior, -distribuído] e a segunda é [-anterior, +distribuído]:93

Apresento a seguir o gráfico ${ }^{94}$ dos pesos relativos obtidos nesta variável:

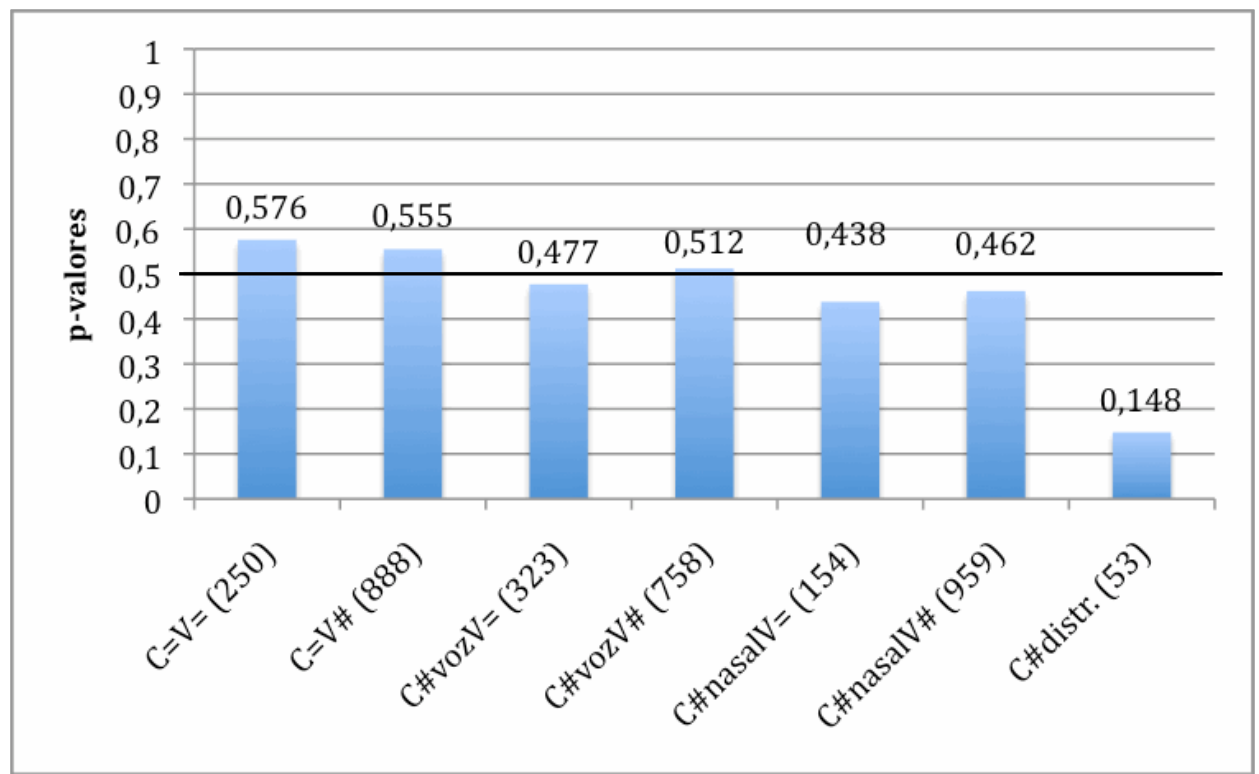

Gráfico 6 - Variável Igualdade de Segmentos (as duas cidades)

De forma resumida, observamos que consoantes iguais favorecem (levemente) a queda de sílaba; contextos em que as consoantes diferem em [vozeamento] são inertes; consoantes diferentes em [nasal] desfavorecem a queda de sílaba. Além disso, as vogais parecem não interferir no processo, se se levar em conta a característica de

93 De modo geral, o objetivo nesta tese é delimitar as combinações dos segmentos na aplicação de queda de sílaba. Dessa forma, controlamos os traços de cavidade oral (ponto de C e [contínuo]) e a nasalidade. No entanto, não foi possível analisar da mesma forma os traços [anterior, distribuído] porque a frequência destes segmentos foi baixa (2/53 ocorrências de aplicação). Outra delimitação imposta pelas frequências dos segmentos foi distinguir casos em que há sonorantes orais. Para o português, estes tipos de segmentos são /r/, I $/$ e / / e especificamente para este estudo, não há possibilidade de contextos com as duas primeiras consoantes, já que não há palavras em português que se iniciem por $/ r /$ ou $/ K /$ - ou seja, não há contextos de queda de sílaba que sejam $/ r+r /$ ou $/ K+K /$. Para contextos $/ I+I /$ (que são possíveis candidatos à queda de sílaba), as frequências encontradas foram muito baixas - 10/85 de aplicação. Estas possibilidades serão, assim, trabalhadas em outros estudos.

94 Nos gráficos, os números entre parênteses indicam as ocorrências ( $\mathrm{N}$ total) da variante. Por exemplo, $\mathrm{C}=\mathrm{V}=$ (250) no Gráfico 6 significa que a variante de consoantes e vogais iguais teve 250 ocorrências no corpus). 
igualdade/diferença entre a primeira e a segunda vogais. Finalmente, não há conclusões para consoantes diferentes em [anterior, distribuído], pois o número de tokens para este fator foi baixo.

\subsection{Cavidade Oral das Consoantes com Distinção de [nasal]}

Das duas configurações para as consoantes (cf. envelope 4.1.4.1.1.2 e 4.1.4.1.1.3), o mais adequado é separar segmentos [nasal], já que foi esta a variável selecionada pelo programa em todas as rodadas. Apresentado a seguir os pesos relativos para Cavidade Oral das Consoantes com Distinção de [nasal]:

Tabela 15 - Variável Cavidade Oral das Consoantes com Distinção do Traço [nasal] (as duas cidades)

\begin{tabular}{|c|c|c|c|c|}
\hline Cavidade Oral das Consoantes com [nasal] & $\mathrm{N}$ & $\mathrm{N}$ total & $\%$ apl & P.R. \\
\hline 2 consoantes coronal [-contínuo] $(\mathrm{t}+\mathrm{t})$ & 826 & 2563 & 32,2 & 0,642 \\
\hline 2 consoantes coronal [+contínuo] $(\mathrm{s}+\mathrm{s})$ & 75 & 385 & 19,5 & 0,643 \\
\hline 2 consoantes labial [-contínuo] $(p+p)$ & 18 & 88 & 20,5 & 0,582 \\
\hline 2 consoantes labial [+contínuo] $(f+f)$ & 14 & 119 & 11,8 & 0,517 \\
\hline 2 consoantes dorsal $(\mathrm{k}+\mathrm{k})$ & 45 & 218 & 20,6 & 0,451 \\
\hline nasais $(n+n)$ & 208 & 2255 & 9,2 & 0,319 \\
\hline total & 1186 & 5628 & 21,1 & \\
\hline
\end{tabular}

input $=0.136 ;$ significância: 0.004

Se os contextos consonantais forem duas coronais orais, há um favorecimento, tanto para consoantes [-contínuo] (com p=0,642) quanto [+contínuo] $(p=0,643)$; também favorecem as labiais [-contínuo] $(p=0,582)$. Outros segmentos inibem a queda de sílaba (duas dorsais, com $p=0,451$; e duas labiais [+contínuo], com $p=0,517$ ), e o contexto com nasais é o que mais desfavorece, com $p=0,319$.

Destes resultados, podemos concluir que os valores para [ \pm contínuo] não são suficientes para determinar a queda de sílaba: se, por um lado, este traço não interfere para coronais orais (cf. contextos representados por $t+t$ e $s+s$ na Tabela 15), já que em ambos os casos há favorecimento; por outro, se houver uma consoante nasal [-contínuo], há o maior desfavorecimento dos contextos consonantais. Ainda com relação a [contínuo], observamos 
que há uma diferença também para as labiais: se esta consoante for [-contínuo], o processo tende ao favorecimento, com $p=0,582$; se o segmento for [+contínuo] (com $p=0,517$ ), o comportamento passa a ser inerte. Contudo, notamos que o número de tokens para labiais [-contínuo] foi baixo (88 tokens); assim, cabe aqui um estudo (futuro) com um maior número de ocorrências para as labiais, a fim de nos certificar se o comportamento de contextos com labiais [-contínuo] é de fato diferente de sequências com labiais [+contínuo]. Finalmente, as dorsais [-contínuo] $(p=0,451)$ desfavorecem o processo. Apresento a seguir os exemplos retirados do corpus para todos os fatores desta variável:

$\begin{array}{llll}(242) & \mathrm{t}+\mathrm{t} & \text { laDO DO conselho tutelar } & (\mathrm{B}) \\ (243) & \mathrm{s}+\mathrm{s} & \text { faÇO SÓ tai chi } & (\mathrm{p}) \\ (244) & \mathrm{p}+\mathrm{p} & \text { tem(PO) PRA aposentadoria } & (\mathrm{k}) \\ (245) & \mathrm{f}+\mathrm{f} & \text { jogaVA VÔlei } & (\mathrm{f}) \\ (246) & \mathrm{k}+\mathrm{k} & \text { cin(CO) QUllômetros } & (\mathrm{u}) \\ (247) & \mathrm{n}+\mathrm{n} & \text { reú(NE) NA quarta feira } & (\mathrm{x})\end{array}$

Em (242) há duas consoantes coronais [-contínuo]; o exemplo (243) representa contextos também com duas coronais que desta vez são [+contínuo]; em (244) há duas labiais [-contínuo]; em (245) há novamente duas labiais mas que são [+contínuo]; em (246), há uma dorsal seguida de outra dorsal; finalmente, em (247) o contexto consonantal está preenchido por duas nasais. ${ }^{95}$

Abaixo, está o gráfico que representa os resultados da Cavidade Oral das Consoantes com Distinção de Segmentos [nasal]:

\footnotetext{
95 Lembramos que, na variante das nasais estão tanto sequências [nasal + nasal] como também [oral + nasal] e [nasal + oral] - cf. subseção 4.1.4.1.1.3 do envelope de variação.
} 


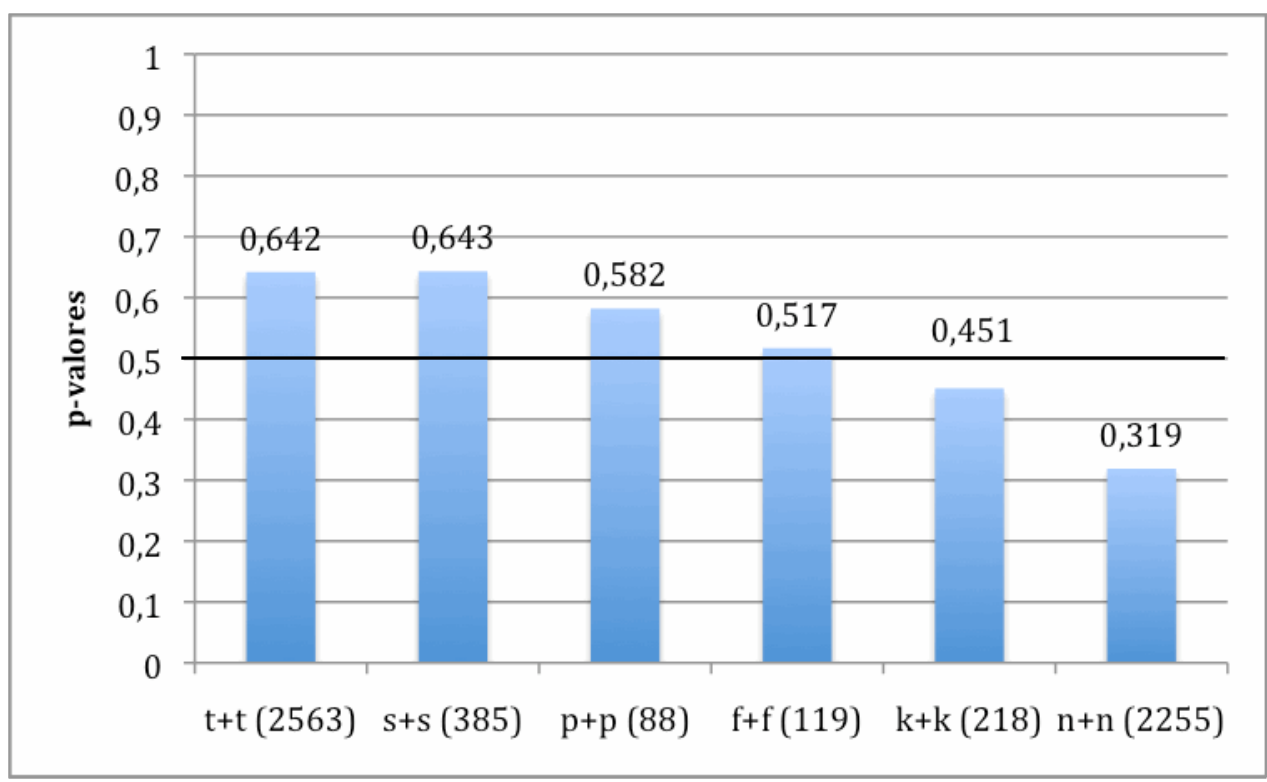

Gráfico 7 - Variável Cavidade Oral das Consoantes com Distinção do Traço [nasal] (as duas cidades)

Para a variável Cavidade Oral das Consoantes, a configuração mais relevante é levar em conta o traço de nasalidade, já que foi esta a selecionada pelo programa; Cavidade Oral das Consoantes (sem distinguir a nasalidade) nunca foi selecionada em nenhuma das rodadas (cf. configuração das rodadas em (234), na subseção 5.2). As coronais orais [+contínuo] e [-contínuo] são as consoantes que mais favorecem a queda de sílaba. As nasais (que são [-contínuo] na cavidade oral) desfavorecem o processo. Finalmente, notamos que contextos com dorsais (também todas [-contínuo]) desfavorecem o processo. A partir destes resultados, notamos que o traço [contínuo] não é suficiente para o estabelecimento da regra de queda de sílaba: [-contínuo] pode favorecer (ver contexto com coronais) ou desfavorecer (sequências com dorsais); [+contínuo] pode favorecer (com coronais) ou ser neutro (com labiais).

Finalmente, com relação às labiais, aquelas que têm o traço [-contínuo] provocam um favorecimento da queda de sílaba, enquanto que labiais [+contínuo] inibem o processo; contudo, vimos que a frequência de ambos os fatores para labiais foi baixa, e os resultados para estes fatores foram inconclusivos. 


\subsection{Cavidade Oral das Vogais}

Como vimos em 5.3.1.1.1, se levarmos em conta uma gradação de segmentos que vão de iguais, passando por semelhantes, até completamente diferentes, o que parece ser decisivo para a implementação da queda de sílaba é a combinação das consoantes, e não a das vogais - a sintaxe destes segmentos é inerte. No entanto, esta variável de Cavidade Oral das Vogais foi selecionada. Apresento a seguir as frequências e pesos relativos obtidos: 96

Tabela 16 - Variável Cavidade Oral das Vogais (as duas cidades)

\begin{tabular}{|c|c|c|c|c|}
\hline Cavidade Oral das Vogais & $\mathrm{N}$ & $\mathrm{N}$ total & $\%$ apl & P.R. \\
\hline coronal + coronal (ee) & 198 & 819 & 24,2 & 0,557 \\
\hline dorso-labial + dorso-labial (oo) & 121 & 460 & 26,3 & 0,588 \\
\hline dorsal + dorsal (aa) & 60 & 497 & 12,1 & 0,356 \\
\hline coronal + dorsal (ea) & 113 & 440 & 25,7 & 0,597 \\
\hline dorso-labial + dorsal (oa) & 203 & 741 & 27,4 & 0,632 \\
\hline dorso-labial + coronal (oe) & 340 & 1384 & 24,6 & 0,556 \\
\hline coronal + dorso-labial (eo) & 42 & 216 & 19,4 & 0,417 \\
\hline dorsal + coronal (ae) & 81 & 693 & 11,7 & 0,343 \\
\hline dorsal + dorso-labial (ao) & 28 & 378 & 7,4 & 0,246 \\
\hline total & 1186 & 5628 & 21,1 & \\
\hline
\end{tabular}

input $=0.136 ;$ significância: 0.004

A igualdade da primeira e da segunda vogal parece não importar para a queda de sílaba, de acordo com os resultados desta variável: se houver duas vogais coronais $(p=0,557)$ ou 2 dorso-labiais (com $p=0,588)$ há um favorecimento; em contrapartida, se o houver duas vogais dorsais, o processo é desfavorecido, com $p=0,356$. Estes resultados estão representados nos exemplos a seguir:

\footnotetext{
96 Levantamos anteriormente algumas possibilidades de estudo de como a morfologia poderia influenciar na queda de sílaba (cf. notas 44, 58 e 72). Para este grupo de fatores Cavidade Oral das Vogais, também seria interessante verificar se/como o tipo de informação gramatical estaria influenciando a queda de sílaba. Assim, procuraríamos responder a perguntas como: um morfema zero tem uma tendência maior ao apagamento do que morfemas marcados? Exemplificando, temos: das palavras mantO (morfema masculino \{-o\}), mentA (morfema feminino $\{-a\}$ ) ou mentE (morfema $\{-\varnothing\}$ ), qual seria o efeito dos morfemas na queda de sílaba? Agradeço à Profa Dra Luciani Tenani por me apontar esta possibilidade.
} 
(248) ee cida(DE) DE Porecatu

(249) oo acontecen(DO) NO centro da cidade

(250) aa juniNA NA igreja (u)

(U)

(q)

Os contextos em (248)-(250) têm vogais iguais, mas há favorecimento nas duas primeiras, enquanto que, em (250), o processo é inibido.

O desfavorecimento com vogais dorsais pode ser corroborado se observarmos estes tipos de segmentos na primeira posição do contexto: mesmo que seguida de uma vogal coronal ( $p=0,343$, cf. exemplo (251)) ou de uma dorso-labial $(p=0,246$, ver exemplo (252)), há um desfavorecimento da queda de sílaba:

$\begin{array}{lll}(251) & \text { ae } & \text { falTA DE atenção } \\ (252) & \text { ao } & \text { mediDA DO possível }\end{array}$

Por outro lado, se a vogal dorsal estiver na segunda sílaba, e a primeira for uma coronal $(p=0,597)$ ou uma dorso-labial $(p=0,632)$, a queda de sílaba é favorecida. $O$ processo também é favorecido com uma dorso-labial seguida de uma coronal $(p=0,556)$. Exemplifico a seguir estes três fatores de contexto vocálico:

$$
\text { ea tes(TE) NA ponte }
$$

Estes resultados podem indicar que o importante é ponto de $\mathrm{C}$ da vogal sujeita à queda (isto é, da primeira sílaba) e não a igualdade das duas vogais - na variável Igualdade de Segmentos (cf. 5.3.1.1.1) os resultados apontam que, de fato, as vogais não interferem no processo se considerarmos estes segmentos de acordo com a igualdade/diferença entre eles. Em outras palavras, contextos em que há uma coronal na primeira posição (cf. ee, com $p=0,557$ e ea, com $p=0,597$ ) ou uma dorso-labial (cf. oe, $p=0,556$; oa $p=0,632$; e oo, $p=0,588$ ), a queda de sílaba é favorecida. A exceção a este padrão parece ser se a vogal 
coronal estiver seguida de uma dorso-labial, com $p=0,417$, por exemplo:

(256) eo cida(DE) DO porto

Olhando estes dados mais de perto, notamos que o número de tokens dos contextos eo foi o menor desta variável, com $\mathrm{N}=42 / 216$, e trabalhos devem ser feitos para verificar o comportamento deste fator.

Apresento os pesos relativos obtidos no gráfico abaixo:

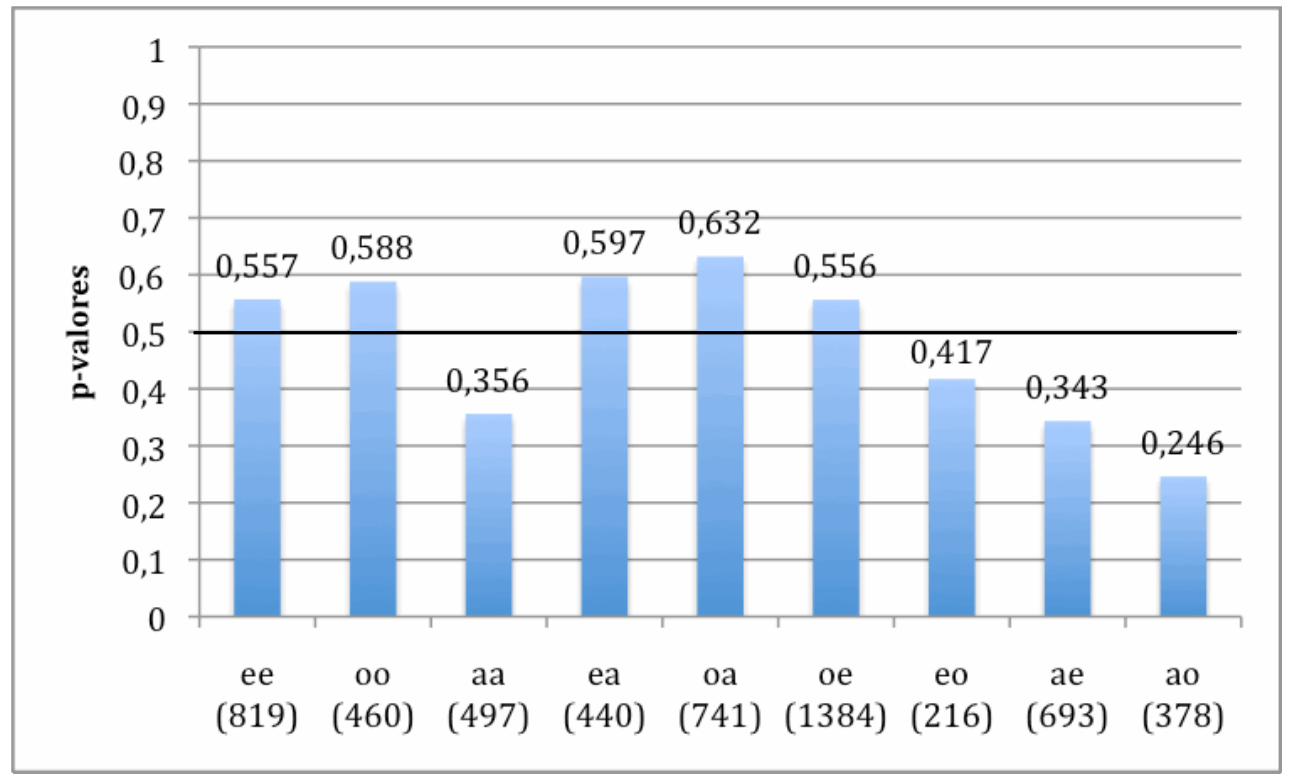

Gráfico 8 - Variável Cavidade Oral das Vogais (as duas cidades)

A partir dos resultados desta variável, pudemos verificar que não é apenas a igualdade das vogais que importa para a queda de sílaba (cf. subseção 5.3.1.1.1), mas sim qual é o ponto de $\mathrm{C}$ da vogal que preenche as posições: se o contexto tiver duas coronais ou duas dorso-labiais, o processo é favorecido; por outro lado, se as vogais forem duas dorsais, há um desfavorecimento.

Se a primeira posição for preenchida por uma dorsal (sem importar a vogal seguinte), há um desfavorecimento; se a primeira vogal for uma coronal ou uma dorsolabial, o processo é favorecido - com exceção do contexto coronal + dorsal, sobre o qual nada afirmamos porque houve poucos dados. 


\subsubsection{Estrutura das sílabas}

Observe as frequências e pesos relativos apresentados na tabela a seguir, em que relacionamos o processo fonológico e as estruturas das sílabas do contexto segmental:

Tabela 17 - Variável Estrutura Silábica (as duas cidades)

\begin{tabular}{|l|c|c|c|c|}
\hline \multicolumn{1}{|c|}{ Estrutura Silábica } & $\mathrm{N}$ & $\mathrm{N}$ total & \%apl & P.R. \\
\hline duas sílabas simples (CV+CV) & 783 & 3385 & 23,1 & 0,508 \\
\hline duas sílabas com coda ramificada (CVC+CVC) & 8 & 73 & 11 & 0,445 \\
\hline duas sílabas com ataque ramificado (CCV+CCV) & 3 & 8 & 37,5 & 0,726 \\
\hline sílaba simples seguida de outro tipo de estrutura (CV+o) & 251 & 1315 & 19,1 & 0,562 \\
\hline sílaba com coda seguida de outro tipo de estrutura (CVC+o) & 38 & 424 & 9 & 0,311 \\
\hline sílaba com ataque ramificado + outro tipo de estrutura (CCV+o) & 82 & 310 & 26,5 & 0,517 \\
\hline duas sílabas com outros tipos de estruturas (exceto as acima) (o+o) & 21 & 113 & 18,6 & 0,279 \\
\hline \multicolumn{1}{|c|}{ total } & 1186 & 5628 & 21,1 & \\
\hline
\end{tabular}

input $=0.136 ;$ significância: 0.004

Se ambas as sílabas tiverem uma estrutura CV, há uma neutralidade $(p=0,508)$; há um (leve) favorecimento para os contextos de sílabas CV seguidas de outros tipos de estruturas $(p=0,562)$ e também para sílabas CCV seguidas de outras estruturas $(p=0,517)$. Exemplificando contextos de queda de sílaba com sílabas simples (ver (257) e (258)) e com sílabas com ataque ramificado (na primeira posição do contexto, cf. (259)), temos:

$\begin{array}{llll}\text { (257) } & \text { CV+CV } & \text { do laDO DO notre dame } & \text { (V) } \\ \text { (258) } & \text { CV+o } & \text { arquite(TO) TAMbém pode } & \text { (d) } \\ \text { (259) } & \text { CCV+o } & \text { tea(TRO) DE arena } & \text { (s) }\end{array}$

Há duas sílabas simples em (257), contexto em que o processo é neutro; em (258) e (259), há um leve favorecimento da queda de sílaba, em sequências de sílabas simples + outros tipos de estruturas e de sílabas com ataque ramificado na primeira posição, respectivamente.

Sílabas com coda (CVC) seguidas de outros tipos de sílabas desfavorecem o processo, com $p=0,311$, da mesma forma que sequências de sílabas com outros tipos de 
estruturas + outros tipos de estruturas, com $p=0,279$, como exemplificado abaixo:

$\begin{array}{lll}\text { (260) } & \text { CVC+o } & \text { alguMAS PEssoas } \\ \text { (261) } & \text { o+o } & \text { casa dos ouTROS, TRAbalhando na casa dos outros }\end{array}$

Em (260), há uma sílaba com coda seguida de uma sílaba simples, ou seja, é um contexto de CVC + outros tipos de estruturas; em (261), há uma sílaba CCVC seguida de uma CCV; nestes dois casos, há uma inibição do processo.

Há um grande favorecimento de aplicação do processo se ambas as sílabas forem $\mathrm{CCV}$, com $p=0,726$; no entanto, não podemos afirmar que este tipo de contexto tende à queda, uma vez que a frequência deste fator é muito baixa: houve 3 aplicações em apenas 8 tokens. Da mesma forma, não há nenhuma conclusão dos contextos em que há duas sílabas com coda (CVC+CVC), já que as ocorrências também foram baixas: apenas 8/73 tokens.

O gráfico abaixo resume os resultados obtidos:

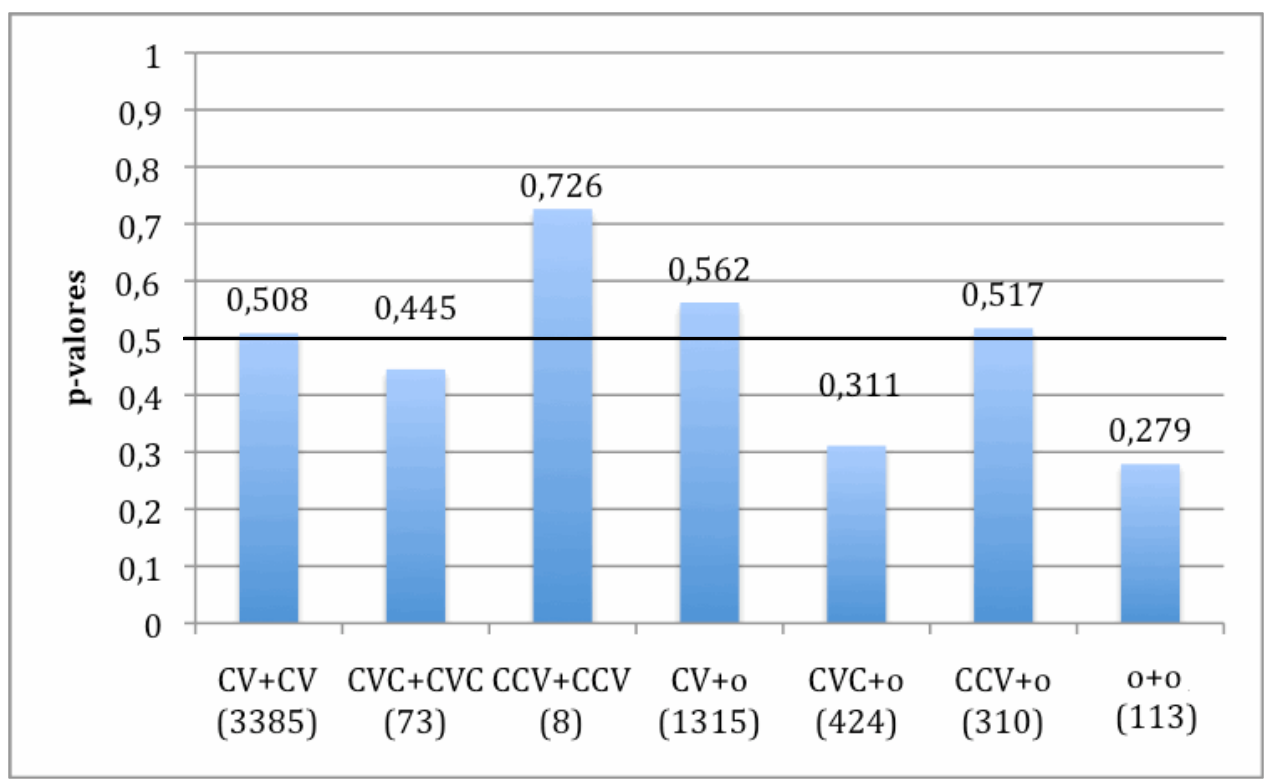

Gráfico 9 - Variável Estrutura Silábica (as duas cidades)

Nesta variável, vimos que sílabas $\mathrm{CV}+\mathrm{CV}$ não interferem no processo; para contextos $\mathrm{CV}+\mathrm{o}$, há um leve favorecimento. Com relação às sílabas $\mathrm{CCV}$, nada podemos 
concluir sobre contextos $C C V+C C V$, já que a frequência foi baixa para este fator $(N=3 / 8)$; mas verificamos que também são neutros os contextos com CCV na primeira posição, seguidas de quaisquer outros tipos de estruturas. Se a primeira posição for ocupada por sílabas com coda, o processo é desfavorecido, bem como com contextos em que as estruturas são outros tipos de estruturas + outros tipos de estruturas.

\subsubsection{Métrica}

As frequências e pesos relativos para as sequências acentuais são dados a seguir:

Tabela 18 - Variável Métrica (as duas cidades)

\begin{tabular}{|c|c|c|c|c|}
\hline Métrica & $\mathrm{N}$ & $\mathrm{N}$ total & \%apl & P.R. \\
\hline lapso de 3 sílabas $(\mathrm{x} \cdot \bullet \# \cdot)$ & 9 & 26 & 34,6 & 0,684 \\
\hline lapso de 3 sílabas (a última é um clítico) $(\mathrm{x} \cdot \cdots \mathrm{A}$ ) & 31 & 93 & 33,3 & ,747 \\
\hline duas fracas entre um acento 1ário e um acento 2ário $(\mathrm{x} \cdot \# \mathrm{y})$ & 1 & 6 & 16,7 & 0,894 \\
\hline duas fracas entre duas fortes $(\mathrm{x} \cdot \# \mathrm{x})$ & 10 & 73 & 13,7 & 0,485 \\
\hline lapso de 2 sílabas $(\mathrm{x} \cdot \# \bullet)$ & 169 & 819 & 20,6 & 0,508 \\
\hline lapso de 2 sílabas (a última é um clítico) $(\mathrm{x} \bullet \# \mathrm{c})$ & 624 & 2036 & 30,6 & 0,638 \\
\hline uma fraca entre um acento 1 ário e um acento 2 ário $(x \cdot \# y)$ & 56 & 218 & 25,7 & 0,629 \\
\hline uma fraca entre duas fortes $(x \cdot \# x)$ & 286 & 2357 & 12,1 & 0,354 \\
\hline total & 1186 & 5628 & 21,1 & \\
\hline
\end{tabular}

input $=0.136 ;$ significância: 0.004

Com relação aos 4 primeiros contextos métricos apresentados na Tabela 18, as ocorrências foram baixas, e são sequências em que a primeira palavra é um dátilo, quais sejam: um lapso de 3 sílabas [ $\mathrm{x} \cdot \bullet \#$ - ] (com N=9/26); um lapso de 3 sílabas, sendo que a última é um clítico [ $\mathrm{x} \cdot$ * $\mathrm{c}$ ] $(\mathrm{N}=31 / 93)$; duas fracas entre um acento primário e um acento secundário $[x \cdots \# y](N=1 / 6)$; e duas fracas entre duas fortes $[x \cdots \# x](N=10 / 73)$. Dessa forma, não podemos tirar conclusões destes 4 fatores, já que o número de tokens foi baixo. A seguir, apresento os exemplos do corpus para estes quatro fatores: 
(262) $[\mathrm{x} \cdot \bullet \# \cdot \quad$ A telefoniCA GArante contratualmente

te le fo ni CA ga ran te

$\mathrm{y} \cdot \mathrm{x} \cdot \cdot \cdot \mathrm{x} \cdot$

(263) [ [ • • \# c ] Lógi(CO) QUE cê consegue...

$(\mathrm{L})$

$$
\begin{array}{cccc}
\text { ló } & \text { gi } & (\mathrm{CO}) & \text { QUE } \\
\mathrm{x} & \bullet & (\bullet) & \bullet
\end{array}
$$

(264) $[x \cdot * \# y] \quad$ y...da previdên(CIA) SOcial, entendeu?

$$
\begin{array}{ccccccc}
\text { pre } & \text { vi } & \text { dên } & (\mathrm{CIA}) & \text { SO } & \mathrm{ci} & \mathrm{al} \\
\mathrm{y} & \bullet & \mathrm{x} & (\bullet) & \mathrm{y} & \bullet & \mathrm{x}
\end{array}
$$

(265) $\quad[x \cdot \bullet \# x] \quad$...não tinha geladeira elétri(CA) COmo tem hoje.

e lé tri CA CO mo

- $\mathrm{x} \cdot(\cdot) \mathrm{x} \cdot$

Para os outros 4 contextos, há um favorecimento da queda de sílaba com uma sequência $[x \cdot \# c]$, com $p=0,638$; numa sequência métrica em que há uma sílaba fraca entre uma forte e outra com acento secundário $[x \cdot \# y]$, também há uma tendência ao processo, com $p=0,629$; a sequência de uma sílaba forte seguida de duas fracas $[x \cdot \# \cdot$ ] é inerte, com $p=0,508$; e na sequência em que há uma sílaba desacentuada entre dois acentos fortes $[x \cdot \# x]$, o processo é desfavorecido, com $p=0,354$.

Exemplificando com os dados do corpus, temos as seguintes grades métricas para os 4 contextos em que a primeira palavra é uma sílaba forte seguida de uma fraca:

(266) $[\mathrm{x} \bullet \# \cdot] \quad$ cidaDE DEsenvolvida

(Q)

ci da DE DE sen vol vi da

- $x \cdot y^{\circ} \cdot \mathrm{x} \cdot$ 


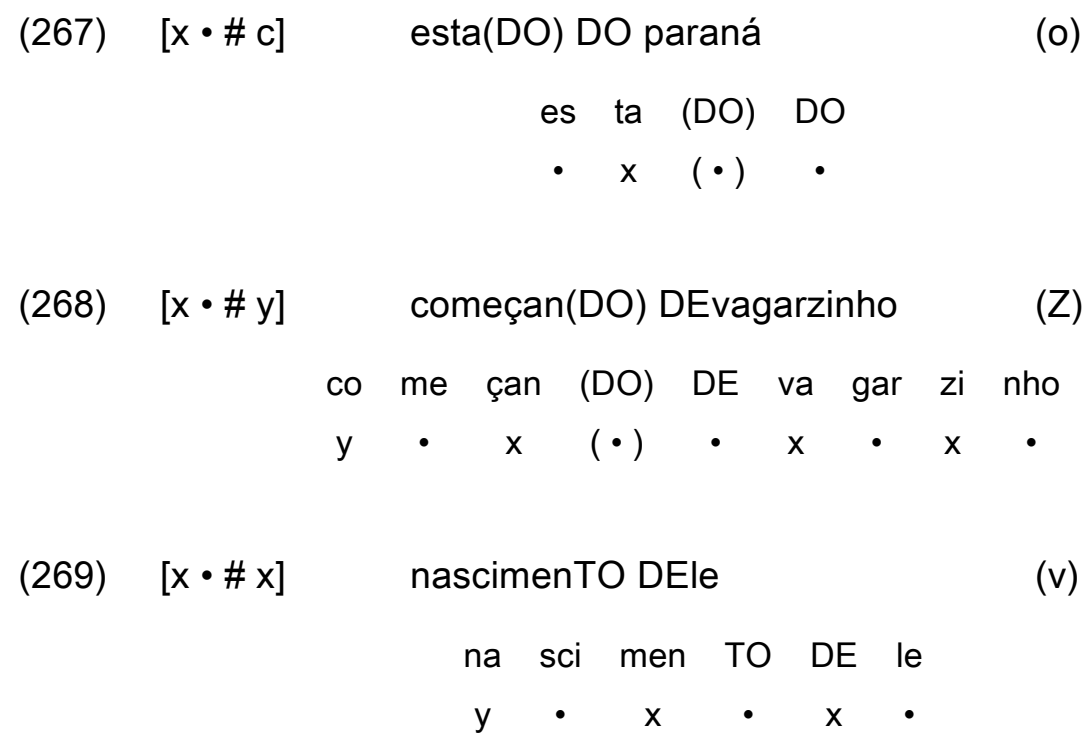

Em (266), há um contexto de uma sílaba forte seguida de duas fracas $[x \cdot \# \cdot]$, um exemplo de neutralidade à queda de sílaba. Em contextos métricos como [ $\mathrm{x} \cdot \mathrm{\#} \mathrm{c}$ ] (cf. (267)) e [ x • \# y ] (ver (268)), há favorecimento do processo, e em ambos os exemplos, a queda de sílaba foi aplicada. Finalmente, sequências $[\mathrm{x} \cdot \# \mathrm{x}]$ em que a aplicação da queda de sílaba pode resultar em choque de acento, o processo é inibido, como exemplificado em (269).

No Gráfico 10, apresento os pesos relativos para a variável Métrica:

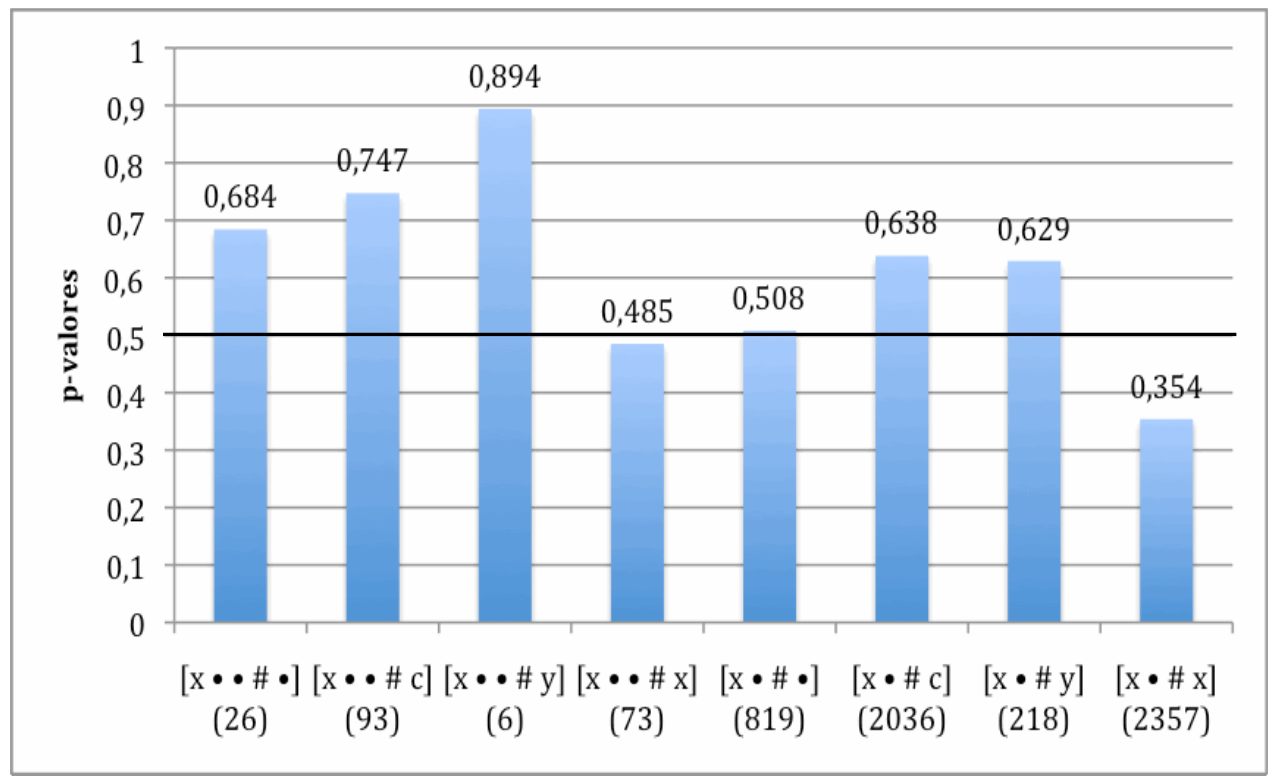

Gráfico 10- Variável Métrica (as duas cidades) 
Resumindo os resultados para a variável Métrica, pudemos observar que sequências com uma sílaba fraca entre uma sílaba forte e um clítico $[x \cdot \# c]$ favorece a implementação do processo, bem como contextos $[x \cdot \# y]$, em que a sequência é uma sílaba com acento primário seguida de uma fraca e outra com acento secundário. Sequências com uma sílaba forte seguida de duas fracas [ $\mathrm{x}$ \# • ] são neutras, enquanto que contextos $[x \cdot \# x]$ desfavorecem - isto é, são sequências em que a aplicação do processo resulta em choque acentual. Nos quatro contextos em que a primeira sílaba é um dátilo $([x \cdots \# \cdot],[x \cdots \# c],[x \cdots \# y]$ e $[x \cdots \# x])$, não temos conclusões, já que foram poucos os dados nestes dois fatores.

\subsubsection{Prosódia}

Os resultados de queda de sílaba relacionados aos constituintes prosódicos foram os seguintes:

Tabela 19 - Variável Prosódia (as duas cidades)

\begin{tabular}{|c|c|c|c|c|}
\hline Prosódia & $N$ & $N$ total & $\%$ apl & P.R. \\
\hline entre frases entonacionais (entre Is) & 202 & 1694 & 11,9 & 0,451 \\
\hline entre frases fonológicas (entre $\Phi$ s) & 358 & 1313 & 27,3 & 0,558 \\
\hline entre grupos clíticos (dentro de $\Phi$ reestr.) (entre Cs) & 626 & 2621 & 23,9 & 0,503 \\
\hline total & 1186 & 5628 & 21,1 & \\
\hline
\end{tabular}

input $=0.136 ;$ significância: 0.004

Como podemos observar na tabela acima, a queda de sílaba não é bloqueada em nenhum nível, o que corrobora a literatura (Tenani 2002, Battisti 2004 e Pavezi 2006a, para a haplologia, e Leal 2006 para queda de sílaba). Notamos também que os pesos relativos não são polarizados, o que pode indicar que não há uma grande diferença nas tendências dos níveis prosódicos relacionados à queda de sílaba. Há um leve favorecimento do processo na fronteira de frases fonológicas, com $p=0,558$. Entre grupos clíticos, que é também dentro de frase fonológica reestruturada, não há efeito no processo $(p=0,503)$ (com a reestruturação, as palavras do contexto segmental ficam entre dois grupos clíticos, cf. Nespor \& Vogel 1986 e subseção 2.2.4). Com relação à sentença, observamos que a aplicação de queda de sílaba é levemente desfavorecida entre frases entonacionais, com 
$p=0,451$. Exemplificando, temos:

$\begin{array}{ll}(270) & \text { Entre Cs } \\ (271) & \text { Dentro de } \Phi s \mathrm{r} \\ (272) & \text { Entre } \Phi \mathrm{s} \\ (273) & \text { Entre Is }\end{array}$

(270) Entre Cs

(272) Entre Фs

(273) Entre Is
[aqueLA]c [LEI]c

$\left.\left[[\text { faciden }(T E)]_{C}\right]_{\Phi}\left[[D E \text { caminhão }]_{C}\right]_{\oplus}\right]_{\Phi}$ reest

$[\text { acontecen }(\mathrm{DO})]_{\Phi}[\mathrm{NO} \text { centro da cidade }]_{\Phi}$

$[\text { absurDO, }]_{\mathrm{I}}[\mathrm{NÉ}]_{\mathrm{I}}$

Em (270) e (271), a fronteira entre os constituintes é a mesma: dois grupos clíticos. A diferença é que, em (271), [acidente] $\phi$ e [de caminhão] Ф são duas frases fonológicas que podem ser reestruturadas, já que o segundo constituinte [de caminhão] não é ramificado e é complemento da primeira frase fonológica [acidente]. Os dois exemplos fazem parte de um mesmo fator, e o peso relativo indica que há uma neutralidade ao processo. O exemplo (272) representa um contexto de queda de sílaba em que a fronteira é duas frases fonológicas que não podem ser reestruturadas - apesar de [no centro da cidade] ser complemento de [acontecendo], é uma frase fonológica ramificada (ou seja, tem 2 grupos clíticos: [no centro] c e [da cidade] c), o que impossibilita a reestruturação; neste caso, há um leve favorecimento do processo. Finalmente, o contexto segmental no exemplo (273) está entre duas sentenças (frases entonacionais), em que há um leve desfavorecimento do processo.

Como vimos na subseção 3.2.4, Tenani (2003) (para a haplologia) afirma que quanto mais altos os níveis prosódicos, a tendência ao apagamento vai diminuindo. No entanto, nos dados do nosso corpus, isto seria verdade se houvesse mais aplicação de queda de sílaba entre grupos clíticos do que entre frases fonológicas. Assim, para a hierarquia como um todo, os resultados aqui apresentados vão de encontro aos de Tenani (2003), e corroboram Battisti (2004) e Pavezi (2006a).

A seguir, apresento o gráfico de pesos relativos para variável Prosódia: 


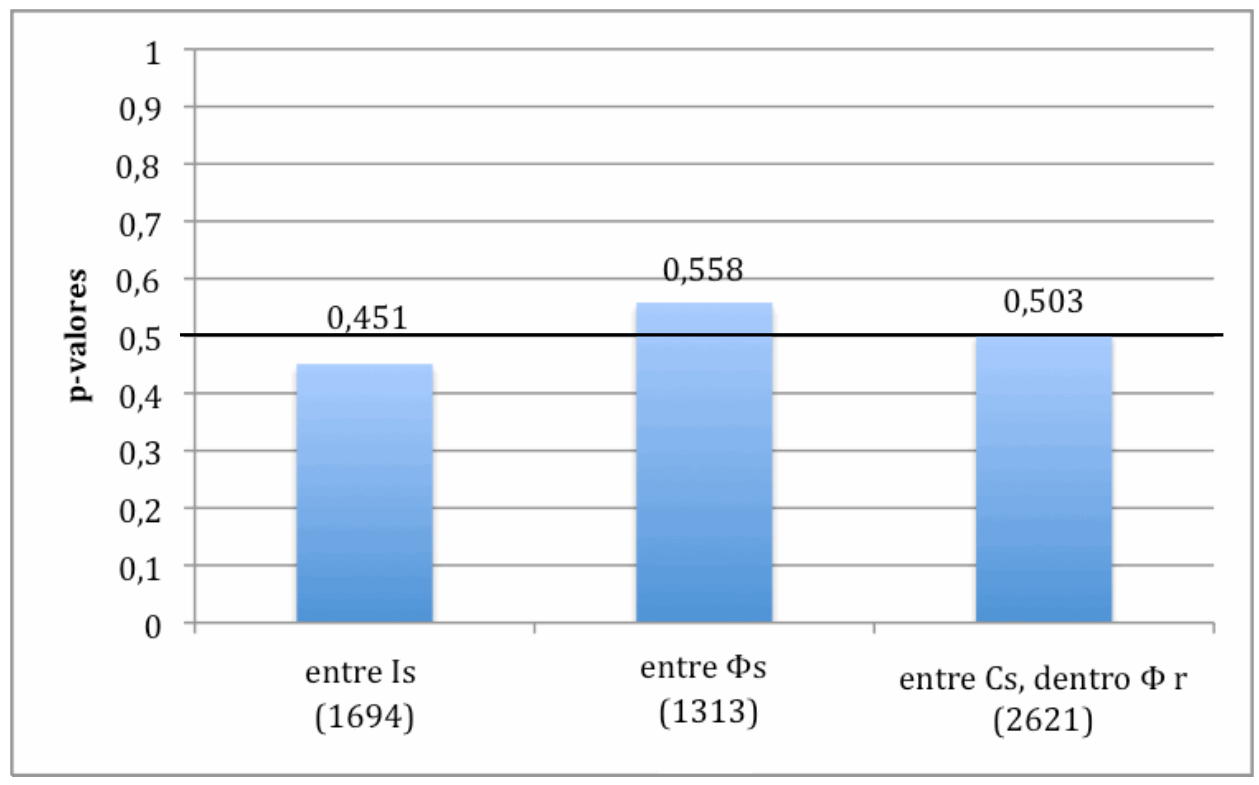

Gráfico 11- Variável Prosódia (as duas cidades)

Como podemos notar no Gráfico 11, os pesos relativos são muito próximos para esta variável: entre grupos clíticos (e dentro de frase fonológica reestruturada), o processo é neutro; entre frases entonacionais, a queda de sílaba é levemente desfavorecida; e há um leve favorecimento entre frases fonológicas. Este último resultado corrobora Pavezi (2006a) e Battisti (2004) para a haplologia e Leal (2006) para queda de sílaba. Verificamos também que a queda de sílaba não é bloqueada em nenhum nível (para a haplologia, cf. Tenani 2002, e Pavezi 2006a, e para a queda de sílaba Leal 2006).

\subsubsection{Número de Sílabas}

Os resultados obtidos para Número de Sílabas foram os seguintes: 97

Tabela 20 - Variável Número de Sílabas (as duas cidades)

\begin{tabular}{|c|c|c|c|c|}
\hline Número de Sílabas & $\mathrm{N}$ & $\mathrm{N}$ total & $\%$ apl & P.R. \\
\hline 2 sílabas (2 бs) & 662 & 3250 & 20,4 & 0,472 \\
\hline 3 sílabas ( $3 \sigma s)$ & 324 & 1552 & 20,9 & 0,507 \\
\hline 4 sílabas ou mais ( 4 os ou + ) & 200 & 826 & 24,2 & 0,593 \\
\hline total & 1186 & 5628 & 21,1 & \\
\hline
\end{tabular}

97 Um procedimento a ser feito é cruzar o grupo de fatores Métrica em este grupo Número de Sílabas. Optamos por analisar todos os grupos de fatores separadamente, deixando os cruzamentos para trabalhos futuros. Agradeço à Profa Dra Luciani Tenani por me chamar a atenção para esta possibilidade. 
input $=0.136 ;$ significância: 0.004

Há um favorecimento do processo para palavras maiores do que 4 sílabas, com $p=0,593$; podemos observar que palavras com 3 sílabas são neutras $(p=0,507)$; e palavras com 2 sílabas desfavorecem levemente o processo, $p=0,472$.

Assim, a aplicação de queda de sílaba é diretamente proporcional ao tamanho da palavra: quanto maior a palavra, a tendência de aplicação ao processo aumenta. Observe o exemplo a seguir:

(274) 6 sílabas o.por.tu.ni.da(DE) DE conversar com ela

Casos como (274) tendem ao processo, pois a palavra sujeita à queda tem 6 sílabas.

Apresento abaixo o gráfico com os pesos relativos para a variável de Número de Sílabas:

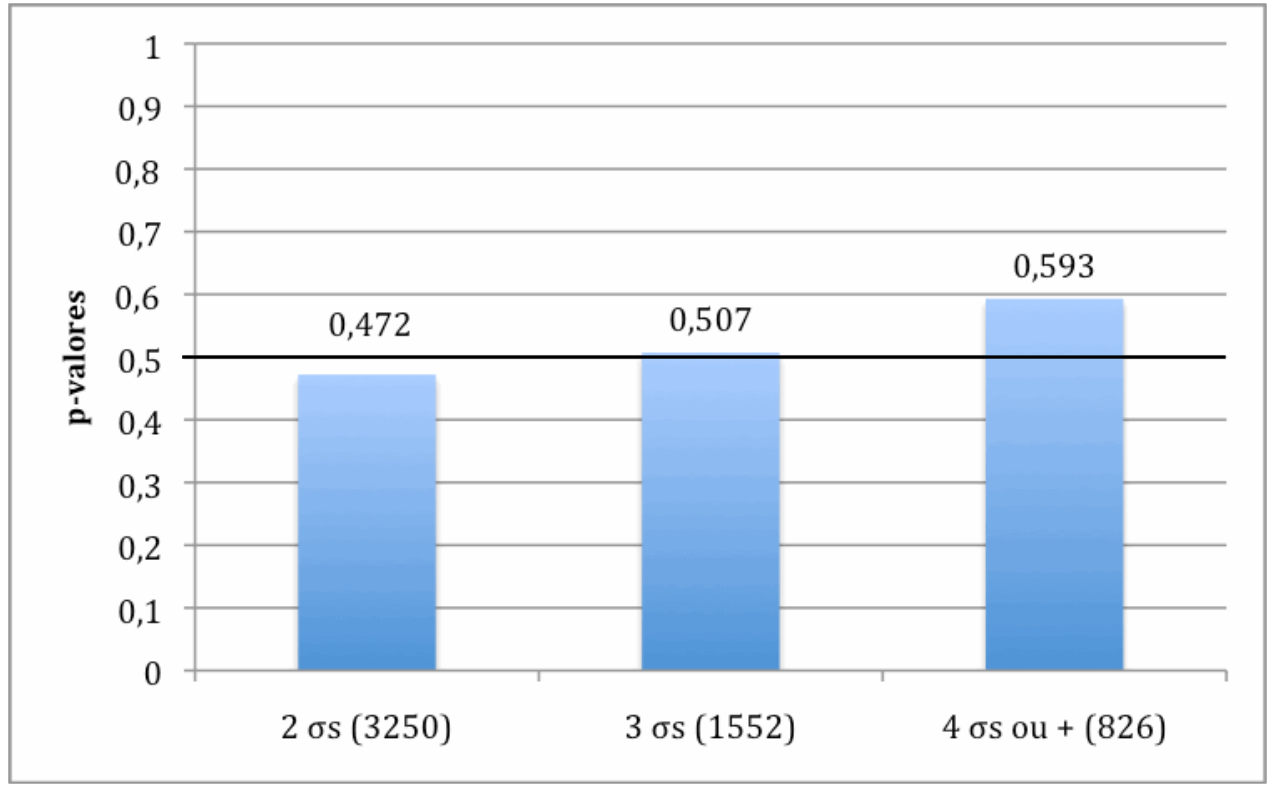

Gráfico 12- Variável Número de Sílabas (as duas cidades)

Os resultados para o tamanho da palavra sujeita à queda apontam que, à medida que aumenta o número de sílabas, aumenta também a implementação do processo. 


\subsubsection{Frequência de Uso de Palavras}

Apresento a seguir as frequências e pesos relativos para esta variável:

Tabela 21 - Variável Frequência de Uso de Palavras (as duas cidades)

\begin{tabular}{|c|c|c|c|c|}
\hline Frequência de Uso das Palavras & $\mathrm{N}$ & $\mathrm{N}$ total & $\%$ apl & $\mathrm{P} . \mathrm{R}$. \\
\hline mais de 20.900 ocorrências no ASPA (alta) & 620 & 2948 & 21 & 0,504 \\
\hline de 10.451 a 20.899 ocorrências no ASPA (média) & 246 & 888 & 27,7 & 0,564 \\
\hline menos de 10.450 ocorrências no ASPA (baixa) & 306 & 1702 & 18 & 0,459 \\
\hline total & 1172 & 5538 & 21,2 & \\
\hline
\end{tabular}

input $=0.136 ;$ significância: 0.004

Como vemos na Tabela 21 , os resultados para esta variável também não estão polarizados: palavras de alta frequência (com mais de 20.900 ocorrências) parecem não interferir no processo $(p=0,504)$, e há uma leve tendência ao processo com palavras com frequência média (de 10.451 a 20.899 ocorrências), com $p=0,564$. Palavras de baixa frequência (frequência de menos de 10.450 ocorrências) parecem inibir a queda de sílaba $(p=0,459)$. Os exemplos a seguir ilustram os contextos de queda de sílaba nos 3 fatores:
(275) frequência alta
úniCA QUE tinha
(i)
(276) frequência média
máqui(NA) DE costura
(u)
(277) frequência baixa
gráviDA DE novo

Os pesos relativos obtidos estão apresentados no gráfico a seguir: 


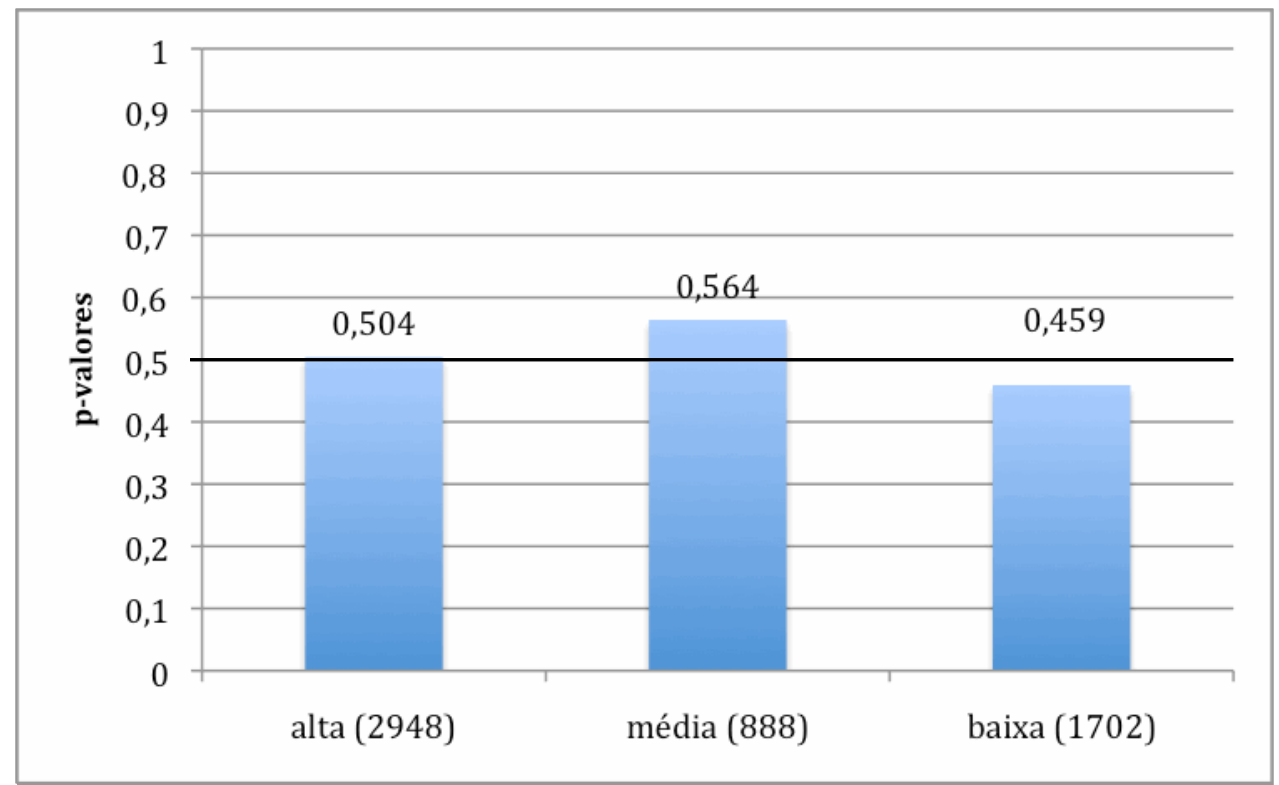

Gráfico 13- Variável Frequência de Uso de Palavras (as duas cidades)

Para esta variável, vimos que se a palavra tiver alta frequência, a queda de sílaba tende ao ponto neutro; palavras de baixa frequência desfavorecem levemente o processo; e palavras de frequência de uso mediana têm um leve favorecimento da queda de sílaba.

\subsubsection{As variáveis sociais nas duas cidades}

Nenhuma das variáveis externas foi selecionada nas rodadas, com exceção de informantes, que foi selecionada em todas elas. Ainda, esta variável foi a primeira a ser selecionada como estatisticamente significativa no nível 1 do step-up, também em todas as rodadas (cf. a descrição das rodadas em (233), na subseção 5.2).

Nas subseções a seguir apresento os resultados das variáveis externas, organizadas da seguinte maneira: Escolaridade (5.3.2.1), Gênero (5.3.2.2), Faixa Etária (5.3.2.3), Informantes (5.3.2.4) e Cidade (5.3.2.5).

\subsubsection{Escolaridade}

Apesar de não selecionada (portanto, sem relevância estatística), há uma diferença entre as frequências dos fatores de Escolaridade, como apresentado na tabela a seguir: 
Tabela 22 - Frequências da variável Escolaridade (as duas cidades)

\begin{tabular}{|c|c|c|c|}
\hline Escolaridade & $\mathrm{N}$ & $\mathrm{N}$ total & $\%$ apl \\
\hline até fundamental & 712 & 2819 & 25,3 \\
\hline ensino superior & 474 & 2809 & 16,9 \\
\hline total & 1186 & 5628 & \\
\hline
\end{tabular}

Estes resultados apontam que pessoas que estudaram até o ensino fundamental aplicam mais o processo do que pessoas que fizeram faculdade, com, respectivamente, $25,3 \%$ e $16,9 \%$ de aplicação de queda de sílaba.

\subsubsection{Gênero}

Também nesta variável, verificamos uma diferença na aplicação de queda de sílaba:

Tabela 23 - Frequências da variável Gênero (as duas cidades)

\begin{tabular}{|c|c|c|c|}
\hline Gênero & $\mathrm{N}$ & $\mathrm{N}$ total & $\% \mathrm{apl}$ \\
\hline masculino & 741 & 2813 & 26,3 \\
\hline feminino & 445 & 2815 & 15,8 \\
\hline total & 1186 & 5628 & \\
\hline
\end{tabular}

Como apresentado na Tabela 23, certificamos que os homens aplicam mais o processo fonológico $(26,3 \%)$ do que as mulheres $(15,8 \%)$.

\subsubsection{Faixa Etária}

Verificamos na variável de Faixa Etária que existe uma diferença de frequências na aplicação de queda de sílaba com as duas cidades rodadas juntas, mas esta diferença é menor do que para as variáveis de Escolaridade e Gênero:

Tabela 24 - Frequências da variável Faixa Etária (as duas cidades)

\begin{tabular}{|c|c|c|c|}
\hline Faixa Etária & $\mathrm{N}$ & $\mathrm{N}$ total & \%apl \\
\hline de 20 a 35 & 644 & 2850 & 22,6 \\
\hline mais de 50 & 542 & 2778 & 19,5 \\
\hline total & 1186 & 5628 & \\
\hline
\end{tabular}

Como se vê na Tabela 24, apesar de haver uma diferença na implementação da 
queda de sílaba entre pessoas mais jovens $(22,6 \%)$ e os mais velhos $(19,5 \%)$, esta diferença não é grande.

\subsubsection{Informantes}

Como foi dito em 4.1.4.2.4, com esta variável, examinamos o comportamento de cada informante, a fim de verificar se, individualmente, algum deles tem um comportamento muito diferente dos outros - se este for o caso, os resultados podem estar mascarados.

$\mathrm{Na}$ tabela abaixo, apresento as frequências e os pesos relativos para esta variável:

Tabela 25 - Variável Informante (as duas cidades)

\begin{tabular}{|c|c|c|c|c|}
\hline cod. & N & N total & $\%$ apl & P.R. \\
\hline a & 20 & 96 & 20,8 & 0,565 \\
\hline b & 8 & 88 & 9,1 & 0,262 \\
\hline C & 6 & 83 & 7,2 & 0,229 \\
\hline d & 5 & 108 & 4,6 & 0,242 \\
\hline e & 23 & 109 & 21,1 & 0,484 \\
\hline f & 2 & 97 & 2,1 & 0,075 \\
\hline g & 10 & 102 & 9,8 & 0,324 \\
\hline h & 2 & 103 & 1,9 & 0,056 \\
\hline i & 23 & 97 & 23,7 & 0,694 \\
\hline j & 15 & 94 & 16 & 0,524 \\
\hline k & 53 & 150 & 35,3 & 0,766 \\
\hline I & 14 & 113 & 12,4 & 0,358 \\
\hline A & 31 & 167 & 18,6 & 0,518 \\
\hline B & 25 & 105 & 23,8 & 0,603 \\
\hline C & 17 & 130 & 13,1 & 0,324 \\
\hline D & 31 & 68 & 45,6 & 0,851 \\
\hline E & 19 & 89 & 21,3 & 0,51 \\
\hline F & 24 & 87 & 27,6 & 0,64 \\
\hline G & 16 & 122 & 13,1 & 0,36 \\
\hline H & 7 & 114 & 6,1 & 0,181 \\
\hline I & 6 & 107 & 5,6 & 0,248 \\
\hline J & 23 & 90 & 25,6 & 0,621 \\
\hline K & 38 & 146 & 26 & 0,598 \\
\hline L & 31 & 134 & 23,1 & 0,557 \\
\hline & & & & \\
\hline
\end{tabular}




\begin{tabular}{|c|c|c|c|c|}
\hline $\mathrm{m}$ & 42 & 140 & 30 & 0,687 \\
\hline $\mathrm{n}$ & 11 & 128 & 8,6 & 0,28 \\
\hline $\mathrm{o}$ & 38 & 144 & 26,4 & 0,653 \\
\hline $\mathrm{s}$ & 40 & 87 & 46 & 0,827 \\
\hline $\mathrm{t}$ & 60 & 176 & 34,1 & 0,83 \\
\hline $\mathrm{u}$ & 54 & 108 & 50 & 0,869 \\
\hline $\mathrm{p}$ & 15 & 65 & 23,1 & 0,617 \\
\hline $\mathrm{q}$ & 18 & 173 & 10,4 & 0,407 \\
\hline $\mathrm{r}$ & 15 & 107 & 14 & 0,41 \\
\hline $\mathrm{V}$ & 14 & 132 & 10,6 & 0,294 \\
\hline $\mathrm{X}$ & 27 & 131 & 20,6 & 0,516 \\
\hline $\mathrm{Z}$ & 27 & 147 & 18,4 & 0,481 \\
\hline $\mathrm{M}$ & 30 & 161 & 18,6 & 0,48 \\
\hline $\mathrm{N}$ & 32 & 109 & 29,4 & 0,678 \\
\hline $\mathrm{O}$ & 25 & 118 & 21,2 & 0,551 \\
\hline $\mathrm{S}$ & 46 & 164 & 28 & 0,567 \\
\hline $\mathrm{T}$ & 91 & 149 & 61,1 & 0,909 \\
\hline $\mathrm{U}$ & 32 & 108 & 29,6 & 0,627 \\
\hline $\mathrm{P}$ & 29 & 114 & 25,4 & 0,614 \\
\hline $\mathrm{Q}$ & 8 & 130 & 6,2 & 0,199 \\
\hline $\mathrm{R}$ & 11 & 112 & 9,8 & 0,286 \\
\hline $\mathrm{V}$ & 12 & 115 & 10,4 & 0,294 \\
\hline $\mathrm{X}$ & 44 & 144 & 30,6 & 0,665 \\
\hline $\mathrm{Z}$ & 16 & 67 & 23,9 & 0,463 \\
\hline total & 1186 & 5628 & 21,1 & \\
\hline & & & & \\
\hline
\end{tabular}

input $=0.136 ;$ significância: 0.004

A média de tokens coletados de cada informante foi de 117, e os informantes que tiveram menos tokens foram $D, p, \mathrm{e} Z$. As taxas de aplicações da queda de sílaba para $p$ e $Z$ estão perto da média de $20 \%$ (informante $p, \mathrm{~N}=15 / 65$, com $23,1 \%$ de aplicação; e $Z$ com $\mathrm{N}=16 / 67,23,9 \%$ ), e o informante $D$, além de poucos tokens, teve uma frequência alta de aplicação de queda de sílaba, com 31/68 (45,6\%).

Observando-se os pesos relativos, vemos que $D, f, h, H, Q, s, t, T$ e $u$ não seguem o padrão geral. Para melhor visualização dos pesos relativos, apresento-os em forma de gráfico: 


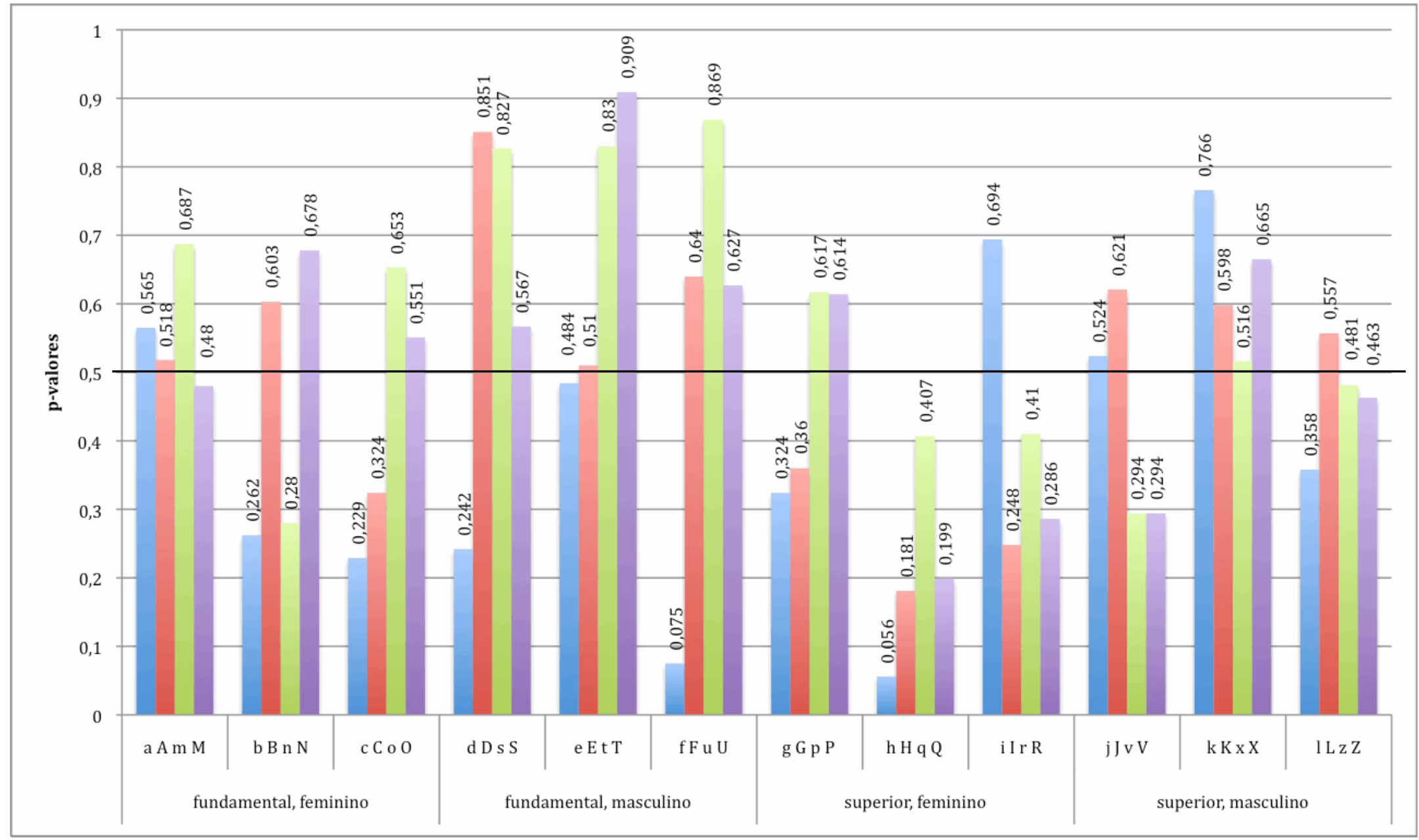

Gráfico 14- Pesos relativos da variável Informante (rodada 1 - as duas cidades)

de A-L: Capivari

de M-Z: Campinas minúsculas: mais velhos

maiúsculas: mais jovens 
Houve 9 informantes que tiveram comportamentos diferenciados: 4 deles no sentido de desfavorecer a queda de sílaba e os outros 5 , de modo oposto, favorecendo o processo. Os pesos relativos para estes 9 informantes são peculiares porque suas características externas (escolaridade, gênero, faixa etária e cidade) não seguem nenhum padrão, como veremos a seguir.

Das 4 pessoas que desfavorecem, apenas uma delas é campineira (a informante $Q$ tem ensino superior e está na faixa de 20 a 35 anos de idade); dos outros 3, o capivariano $f$ tem ensino fundamental; enquanto que as capivarianas $h$ e $H$ têm faculdade; $f$ e $h$ pertencem à faixa mais velha dos informantes, enquanto que $\mathrm{H}$ tem de 20 a 35 anos.

Da mesma forma, não observamos um padrão para os 5 informantes que favorecem excessivamente a queda de sílaba. Dentre eles, o único de Capivari é $D$, que cursou até o ensino fundamental e tem 21 anos. Quanto aos outros campineiros, todos são homens que estudaram até o ensino fundamental; $s, t$ e $u$ têm mais de 50 anos enquanto que $D$ e $T$ têm idades entre 20 e 35 anos. Observando-se as aplicações/pesos relativos gerais e comparando-as com os 9 informantes que fogem do padrão geral, notamos que 3 capivarianos $f, h$ e $H$ desfavorecem muito a queda de sílaba, enquanto que apenas 1 capivariano favorece muito. E, para Campinas, o contrário aconteceu: apenas uma campineira desfavorece muito, e 4 campineiros favorecem muito.

Podemos interpretar que os resultados destes informantes pode ser a causa de uma maior aplicação de queda de sílaba em Campinas do que em Capivari, cujos resultados apresento na próxima subseção.

\subsubsection{Cidade}

$\mathrm{Na}$ rodada geral, a variável Cidade não foi selecionado. Observe na Tabela 26 as frequências de aplicação das duas cidades:

Tabela 26 - Frequências da variável Cidade

\begin{tabular}{|c|c|c|c|}
\hline cidade & $\mathrm{N}$ & $\mathrm{N}$ total & $\%$ apl \\
\hline Capivari & 449 & 2599 & 17,3 \\
\hline Campinas & 737 & 3029 & 24,3 \\
\hline total & 1186 & 5628 & \\
\hline
\end{tabular}


Como podemos observar, houve uma maior aplicação de queda de sílaba na cidade de Campinas do que em Capivari. Se estatisticamente não há diferença relevante (já que a variável Cidade não foi selecionada), percebemos pelas frequências que há uma diferença linguística relevante nas duas cidades, ou seja, há uma maior aplicação em Campinas do que em Capivari.

Dos resultados de Leal (2006) (cf. também subseção 3.3), vimos que, para Capivari, as combinações dos traços consonantais que implementam a regra de queda de sílaba são diferentes dos encontrados na literatura - cf. dialeto em Alkmim \& Gomes (1982) (chamado de impressionisticamente brasileiro pelas autoras); dialeto de São José do Rio Preto em Tenani (2002, 2003) e em Pavezi (2006a, 2006b); dialeto de Porto Alegre em Battisti (2004). Assim, a hipótese formulada para a variável Cidade (cf. 4.1.4.2.5) foi que há uma probabilidade de o processo ocorrer mais em Capivari do que em Campinas, se compararmos os resultados de Leal (2006) para aquela cidade com outros resultados da literatura. No entanto, a hipótese não foi corroborada, já que a taxa de aplicação de queda de sílaba em Capivari foi $17,3 \%$, e Campinas aplicou mais o processo, com 24,3\%.

Para verificar por que (e como) se dá esta diferença na aplicação da queda de sílaba em Capivari e em Campinas, decidimos por rodá-las separadamente, como sugerem Guy \& Zilles (2007: 221) (cf. também subseção 1.2), com o objetivo de verificar de que modo o processo se diferencia (ou é igual) nas duas cidades. Nas rodadas em que computamos Capivari e Campinas separadamente (cf. capítulos 6 e 7 a seguir), buscamos responder à seguinte questão: se há diferenças de aplicação do processo nas duas cidades, quais são elas?

\subsection{Resumo}

Neste capítulo dos resultados das duas cidades rodadas em conjunto, vimos que as variáveis que não interferem na queda de sílaba (ou seja, os que não foram selecionados pelo programa) foram: a Cavidade Oral das Consoantes (sem distinguir o traço [nasal]) e as variáveis externas Escolaridade, Gênero, Idade e Cidade. 
Das as variáveis selecionadas, vimos que, na igualdade do conteúdo das sílabas (variável chamada de Igualdade de Segmentos), as consoantes parecem ditar a regra, já que, se as vogais variarem, não há nenhum efeito; o vozeamento das consoantes interfere no processo: se as consoantes forem idênticas (sem importar as vogais), há uma tendência à queda, mas se as consoantes diferirem em vozeamento, há uma neutralidade do processo. Finalmente, o traço [nasal] desfavorece, e nada interpretamos dos traços [anterior, distribuído], em decorrência do baixo número de tokens.

Ainda quanto às consoantes, verificamos que além separá-las quanto às suas cavidades orais, deve-se levar em conta também o traço [nasal], uma vez que foi esta a configuração selecionada na rodada 1 (com todos os contextos segmentais); e os resultados apontam que coronais orais favorecem e dorsais levemente desfavorecem a queda de sílaba; as nasais inibem o processo; e não houve interpretação para labiais [contínuo] e [+contínuo] devido aos poucos dados.

Para as vogais, os resultados indicam que as dorsais desfavorecem (e a segunda posição vocálica é indiferente); as dorso-labiais e coronais favorecem, também sem importar a segunda posição; se observarmos os contextos de coronal seguida de dorsolabial, há um desfavorecimento do processo; no entanto, são poucos os tokens neste fator e não podemos tirar uma conclusão.

No que concerne à Estrutura Silábica, sílabas CV e CCV na primeira posição do contexto têm um comportamento parecido, já que parecem ser neutras; sílabas com coda e sílabas com outras estruturas diferentes entre si (que não CV, CCV e CVC) desfavorecem.

Os resultados para a Métrica apontam que há um favorecimento da queda de sílaba se a primeira palavra tiver uma sílaba forte seguida de uma fraca e a segunda iniciar por um clítico ou por uma sílaba com acento secundário; para contextos rítmicos em que a aplicação do processo resulta em choque de acento (isto é, há uma sílaba fraca entre duas fortes), há uma inibição do processo; finalmente, contextos de uma sílaba forte seguida de suas fracas são neutros.

Com relação à Prosódia, o processo é levemente favorecido em fronteira de frases fonológicas; um pouco desfavorecido entre sentenças; e é neutro em fronteira de dois grupos clíticos (e dentro de frase fonológica reestruturada). 
Quanto ao Número de Sílabas, palavras com mais de 4 sílabas favorecem um pouco o processo; com 3, são neutras; e palavras pequenas (com duas sílabas) desfavorecem levemente.

Na variável de Frequência de Uso de Palavras, os pesos relativos também não foram polarizados, e vimos que palavras de frequência média favorecem um pouco; de alta frequência são inertes; e palavras de baixa frequência desfavorecem levemente.

Finalmente, para as variáveis externas, a única delas selecionada foi informantes. Das restantes, observando-se as frequências, pudemos constatar que idade parece não influir (já que a frequência de aplicação para os mais jovens e mais velhos foi parecida); pessoas com menos número de anos de estudo e de gênero masculino aplicam mais; e, percentualmente, Campinas aplica mais do que Capivari. 


\section{CAPÍTULO VI}

\section{Em Capivari}

Neste capítulo, apresentamos os resultados dos efeitos linguísticos e sociais obtidos dos dados de Capivari. Na tabela abaixo estão as frequências dos tokens do estudo feito em Capivari, com 24 informantes:

Tabela 27 - Resultados de aplicação de queda de sílaba em Capivari

\begin{tabular}{|c|c|c|}
\hline Capivari & $\mathrm{N}$ & $\%$ \\
\hline aplicação & 449 & 17,3 \\
\hline não aplicação & 2150 & 82,7 \\
\hline total & 2599 & \\
\hline
\end{tabular}

Da mesma forma que na rodada geral, foram feitas 5 rodadas, variando o contexto segmental (cf. a computação dos dados em 5.2), e não houve muitas diferenças entre os resultados obtidos nas 5 rodadas para os dados de Capivari. Por isso, novamente, optamos por descrever a rodada mais geral, em que todas as variáveis foram utilizadas, incluindo todas as variáveis do contexto segmental.

Todas as variáveis linguísticas foram selecionadas em Capivari para o contexto segmental, exceto Igualdade de Segmentos e Cavidade Oral das Consoantes sem distinguir as nasais. Apesar de selecionada pelo programa na rodada geral, a variável linguística de Frequência de Uso de Palavras não foi selecionada em Capivari e, novamente, a variável Informantes foi a única variável externa selecionada.

$\mathrm{Na}$ subseção 6.1 a seguir, apresento os resultados das variáveis linguísticas encontradas para Capivari e, em 6.2, estão as variáveis sociais.

\subsection{As variáveis linguísticas}

Nesta seção apresento a análise desenvolvida levando-se em conta as variáveis, quais sejam: o contexto segmental (ver 6.1.1), a Estrutura Silábica (cf. 6.1.2), a Métrica (ver 6.1.3), a Prosódia (cf. 6.1.4), o Número de Sílabas (ver 6.1.5) e a Frequência de Uso de 
Palavras (cf. 6.1.6).

\subsubsection{Contexto segmental}

Os resultados do contexto segmental, rodado de diferentes formas (Igualdade de Segmentos em 6.1.1.1, Cavidade Oral das Consoantes com Distinção de [nasal] em 6.1.1.2, e Cavidade Oral das Vogais em 6.1.1.3), estão apresentado nas subseções a seguir.

\subsubsection{Igualdade de Segmentos nas Sílabas}

Já que esta variável não foi selecionada pelo programa com os dados de Capivari, podemos concluir que não é a igualdade dos segmentos que ocupam as posições de primeira e de segunda sílabas que importa para a realização de queda de sílaba em Capivari. Em outras palavras, as diferenças de vozeamento, de nasalidade e dos traços [anterior, distribuído] das consoantes, nem mesmo diferenças entre vogais, ditam a regra segmental em Capivari.

De todas as 5 configurações de rodadas para Capivari (cf. resumo das rodadas em (234), na subseção 5.2), a única vez que o programa selecionou esta variável foi exatamente na rodada em que a Igualdade de Segmentos era a única variável do contexto segmental (isto é, na rodada 2 descrita em (234), na subseção 5.2); assim, optamos por analisar os dados nesta rodada.

Foram excluídos $\mathrm{N}=143 / 986$ tokens com sílabas diferentes de $\mathrm{CV}$, totalizando 306/1613 dados para esta variável. ${ }^{98}$ Apresento a seguir as frequências e pesos relativos obtidos na rodada 2 :

98 Assim como na rodada geral, desconsideramos todos os contextos com sílabas diferentes de CV, o que totalizou 986 tokens. Os dados descartados têm as seguintes estruturas na primeira sílaba: 139 contextos com CCV na primeira sílaba, 12 dados com CCVC, $21 \mathrm{com} \mathrm{CgV,} 580$ contextos com CV, 228 dados de CVC, 3 com estruturas CVCC e 3 com sílabas CVgC na primeira posição. 
Tabela 28 - Variável Igualdade de Segmentos apenas da rodada 2 (Capivari)

\begin{tabular}{|l|c|c|c|c|}
\hline \multicolumn{1}{|c|}{ Igualdade de Segmentos (rodada 2) } & $\mathrm{N}$ & $\mathrm{N}$ total & $\%$ apl & P.R. \\
\hline os completamente iguais (C=V=) & 34 & 120 & 28,3 & 0,619 \\
\hline Cs iguais, Vs diferentes (C=V\#) & 105 & 445 & 23,6 & 0,609 \\
\hline Cs diferentes em [vozeamento], Vs iguais (C\#vozV=) & 37 & 157 & 23,6 & 0,556 \\
\hline Cs diferentes em [vozeamento], Vs diferentes (C\#vozV\#) & 91 & 348 & 26,1 & 0,633 \\
\hline Cs diferentes em [nasal], Vs iguais (C\#nasalV=) & 9 & 66 & 13,6 & 0,363 \\
\hline Cs diferentes em [nasal], Vs diferentes (C\#nasalV\#) & 29 & 453 & 6,4 & 0,282 \\
\hline Cs diferentes em [ant.distr.], Vs não importam (C\#distr.) & 1 & 24 & 4,2 & 0,299 \\
\hline total & 306 & 1613 & & \\
\hline
\end{tabular}

input $=0.119 ;$ significância: 0.000

Se as consoantes forem iguais $(p=0,619$ e $p=0,609)$ ou se diferirem em vozeamento $(p=0,556$ e $p=0,633)$, o processo é favorecido. Entretanto, há um desfavorecimento da queda de sílaba se as consoantes diferirem em nasalidade e as vogais forem diferentes, com $p=0,282$. Se as consoantes tiverem nasalidade diferente e as vogais forem iguais, ou ainda, se houver uma diferença nos traços [anterior, distribuído], nada podemos concluir, já que os dados para estes fatores foram poucos (9/66 para o fator de consoantes diferentes em [nasal] e vogais diferentes; e 1/24 para consoantes diferentes em [anterior, distribuído]). E, assim como para a rodada com as duas cidades juntas (cf. 5.3.1.1.1), podemos notar também que as vogais não interferem no processo: para consoantes iguais, os pesos relativos são parecidos, tanto para vogais iguais $(p=0,619)$ quanto para vogais diferentes $(p=0,609)$; em ambos os casos de consoantes diferentes em [vozeamento] com vogais iguais ou diferentes $(p=0,556$ e $p=0,633$, respectivamente), há um favorecimento do processo; finalmente, há um desfavorecimento nos dois fatores de consoantes diferentes em [nasal] (vogais iguais, $p=0,363$, e vogais diferentes $p=0,282$ ).

Apresento a seguir os pesos relativos obtidos em forma de gráfico: 


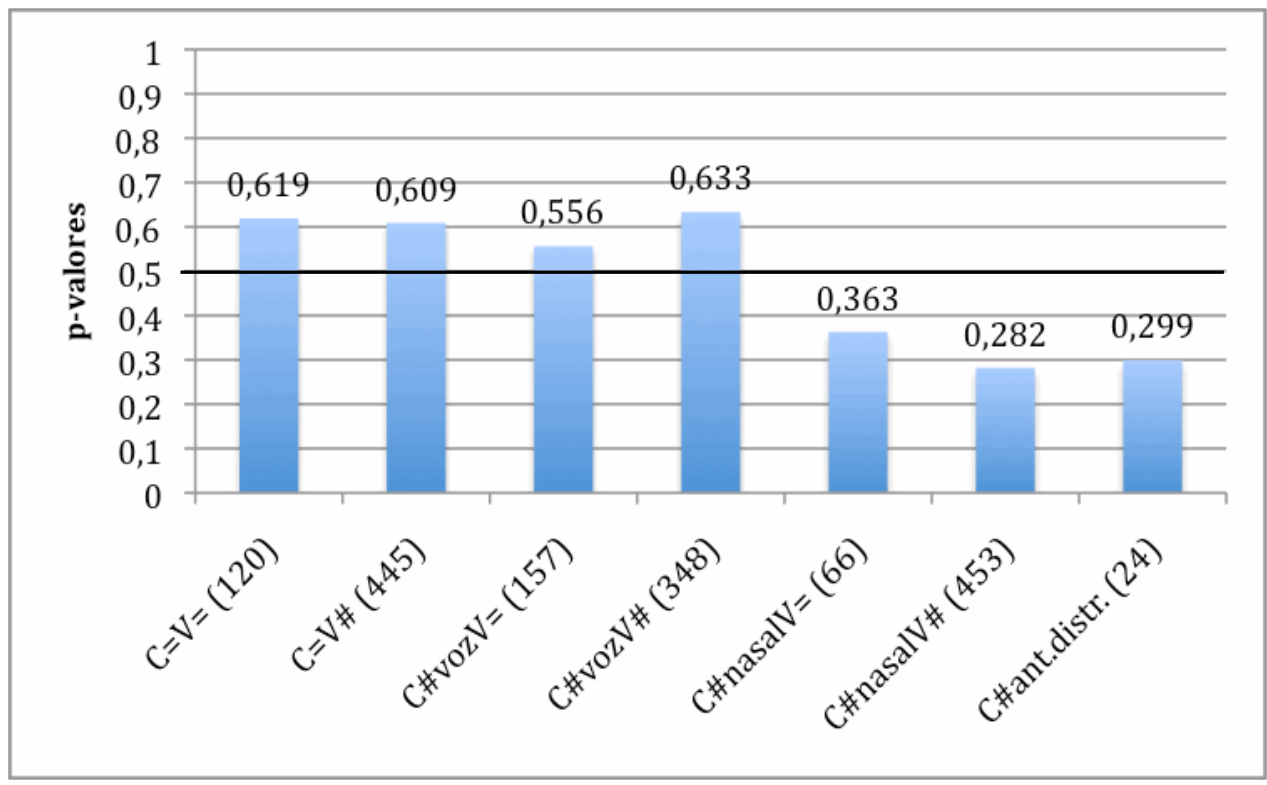

Gráfico 15- Variável Igualdade de Segmentos apenas da rodada 2 (Capivari)

Para esta variável, vimos que se as consoantes forem iguais (sem importar as vogais), ou se as consoantes forem diferentes em vozeamento (também sem importar as vogais), há uma propensão à queda de sílaba; se as consoantes diferirem em nasalidade e as vogais forem diferentes, o processo é inibido. Não obtivemos resultados confiáveis com nasais seguidas de vogais iguais e com consoantes que diferem nos traços [anterior, distribuído], já que, nestes dois casos, houve baixa frequência dos dados. Lembramos que esta variável não foi selecionada na rodada 1 , apenas na rodada 2.

\subsubsection{Cavidade Oral das Consoantes com Distinção de [nasal]}

A Cavidade Oral das Consoantes sem distinguir o traço [nasal] não foi selecionada; por outro lado, se separarmos as consoantes nasais num único fator, a variável é selecionada. Assim, parece ser importante para a cidade de Capivari não somente estabelecer os pontos de C e os valores para [contínuo] das consoantes, mas também sua nasalidade.

As frequências e pesos relativos das consoantes com distinção de [nasal] são dados a seguir: 
Tabela 29 - Variável Cavidade Oral das Consoantes com Distinção do Traço [nasal] (Capivari)

\begin{tabular}{|c|c|c|c|c|}
\hline Cavidade Oral das Consoantes com [nasal] & $\mathrm{N}$ & $\mathrm{N}$ total & $\%$ apl & P.R. \\
\hline 2 consoantes coronal [-contínuo] $(\mathrm{t}+\mathrm{t})$ & 305 & 1164 & 26,2 & 0,653 \\
\hline 2 consoantes coronal [+contínuo] $(\mathrm{s}+\mathrm{s})$ & 31 & 182 & 17 & 0,626 \\
\hline 2 consoantes labial [-contínuo] $(p+p)$ & 14 & 51 & 27,5 & 0,777 \\
\hline 2 consoantes labial [+contínuo] $(f+f)$ & 4 & 60 & 6,7 & 0,378 \\
\hline 2 consoantes dorsal $(k+k)$ & 21 & 89 & 23,6 & 0,584 \\
\hline nasais $(n+n)$ & 74 & 1053 & 7 & 0,3 \\
\hline total & 449 & 2599 & 17,3 & \\
\hline
\end{tabular}

input $=0.100 ;$ significância: 0.013

Como podemos observar na tabela acima, coronais orais favorecem o processo (se forem [-contínuo], $p=0,653 \mathrm{e}$, se forem [+contínuo], há uma pequena diminuição, com $p=0,626$, mas ainda há uma tendência). Os resultados das nasais indicam que há um desfavorecimento do processo com estes tipos de contextos consonantais, com $p=0,3$. Para as consoantes dorsais, labiais [+contínuo] e [-contínuo] não podemos tirar conclusões, já que a frequência de tokens foi baixa: $N=14 / 51$ para dorsais, $N=4 / 60$ para as labiais [+contínuo] e N=21/89 para as labiais [-contínuo].

A partir dos resultados apresentados desta variável, podemos concluir que não é apenas o ponto de $\mathrm{C}$ e [+contínuo] os traços que devem ser lavados em conta para a aplicação de queda de sílaba em Capivari, mas também [nasal], uma vez que este traço interfere no processo, de modo a desfavorecê-lo.

A seguir estão os pesos relativos para Cavidade Oral das Consoantes com Distinção de [nasal]: 


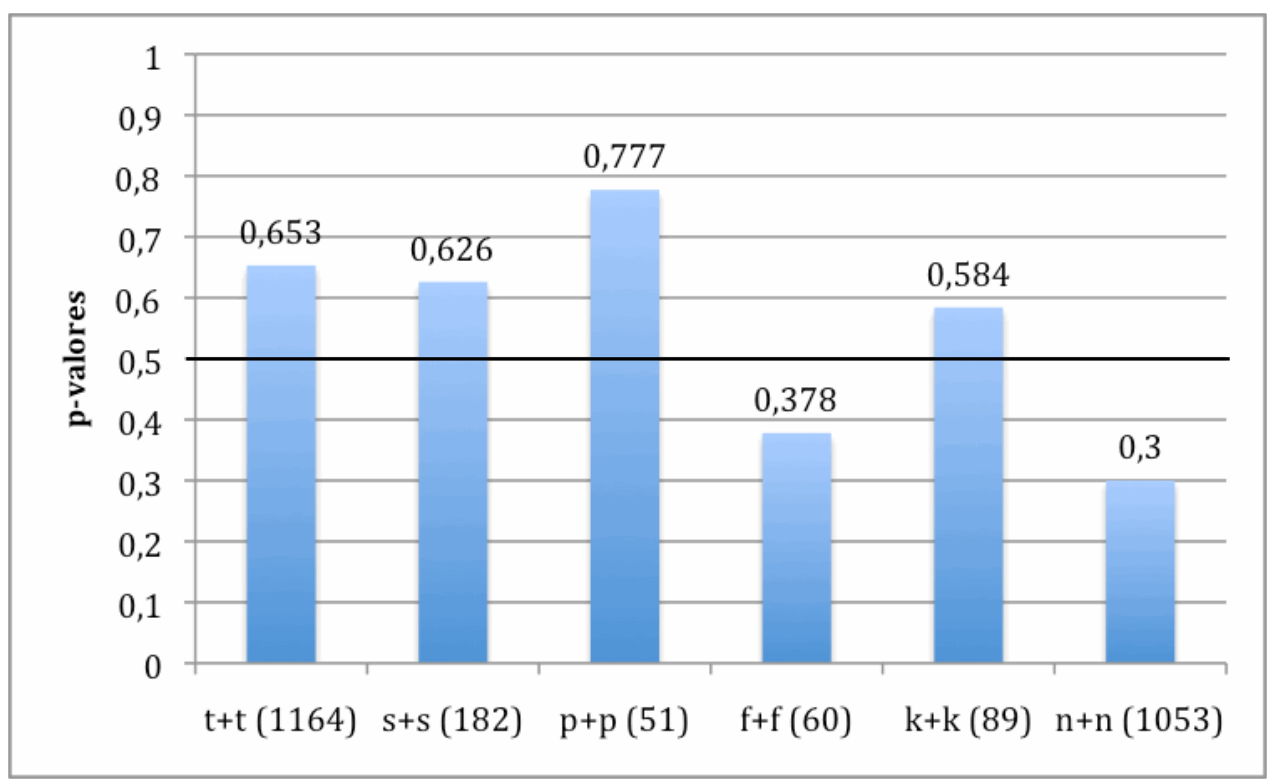

Gráfico 16- Variável Cavidade Oral das Consoantes com Distinção do Traço [nasal] (Capivari)

Para Capivari, verificamos que importa, além da cavidade oral, também a nasalidade das consoantes, uma vez que a configuração que distingue este traço foi aquela selecionada, e a nasalidade interfere no sentido de desfavorecer o processo. Ambas as coronais [-contínuo] e [+contínuo] favorecem a queda de sílaba. Dos contextos de labiais [-contínuo] e [+contínuo] e de dorsais, os resultados não são confiáveis, já que a frequência de tokens foi baixa nestes três fatores.

\subsubsection{Cavidade Oral das Vogais}

Esta variável foi selecionada, e as informações estão apresentadas abaixo: 
Tabela 30 - Variável Cavidade Oral das Vogais (Capivari)

\begin{tabular}{|c|c|c|c|c|}
\hline Cavidade Oral das Vogais & $\mathrm{N}$ & $\mathrm{N}$ total & \%apl & P.R. \\
\hline coronal + coronal (ee) & 72 & 379 & 19 & 0,519 \\
\hline dorso-labial + dorso-labial (oo) & 46 & 211 & 21,8 & 0,605 \\
\hline dorsal + dorsal (aa) & 25 & 236 & 10,6 & 0,408 \\
\hline coronal + dorsal (ea) & 54 & 220 & 24,5 & 0,633 \\
\hline dorso-labial + dorsal (oa) & 83 & 347 & 23,9 & 0,649 \\
\hline dorso-labial + coronal (oe) & 106 & 621 & 17,1 & 0,501 \\
\hline coronal + dorso-labial (eo) & 18 & 106 & 17 & 0,383 \\
\hline dorsal + coronal (ae) & 32 & 302 & 10,6 & 0,373 \\
\hline dorsal + dorso-labial (ao) & 13 & 177 & 7,3 & 0,29 \\
\hline total & 449 & 2599 & 17,3 & \\
\hline
\end{tabular}

input $=0.100 ;$ significância: 0.013

Para as vogais, um contexto com duas vogais dorso-labiais (com $p=0,605$ ) favorece o processo, enquanto que duas coronais estão perto do ponto neutro, com $p=0,519$, e duas dorsais desfavorecem o processo $(p=0,408)$. Com base nestes três primeiros resultados, podemos notar que, assim como na rodada geral (com as duas cidades), a igualdade das vogais também parece não ser um fator relevante em Capivari. Há um padrão com relação a contextos em que primeira vogal é uma dorsal, com um desfavorecimento do processo: uma vogal dorsal seguida de uma coronal teve $p=0,373$, e uma dorsal seguida de uma vogal dorso-labial resultou em $p=0,29$ - da mesma forma, contextos dorsal + dorsal desfavorecem (cf. $p=0,408$ ). Se a primeira vogal for dorso-labial, há um favorecimento se seguida de uma dorsal, com $p=0,649$; há uma neutralidade, com $p=0,501$, se a dorso-labial for seguida de uma coronal - e não temos uma explicação linguística para esta diferença no comportamento de dorso-labial na primeira posição.

Para sequências de uma coronal seguida de uma dorso-labial (cf. eo), a expectativa é de que houvesse um favorecimento da queda de sílaba, já que é este o comportamento de coronais na primeira sílaba (cf. contextos ee, com $p=0,519$, e ea, com $p=0,633$ ). Uma justificativa para este resultado pode ser o baixo número de tokens de coronal + dorsolabial, com N=18/106. 


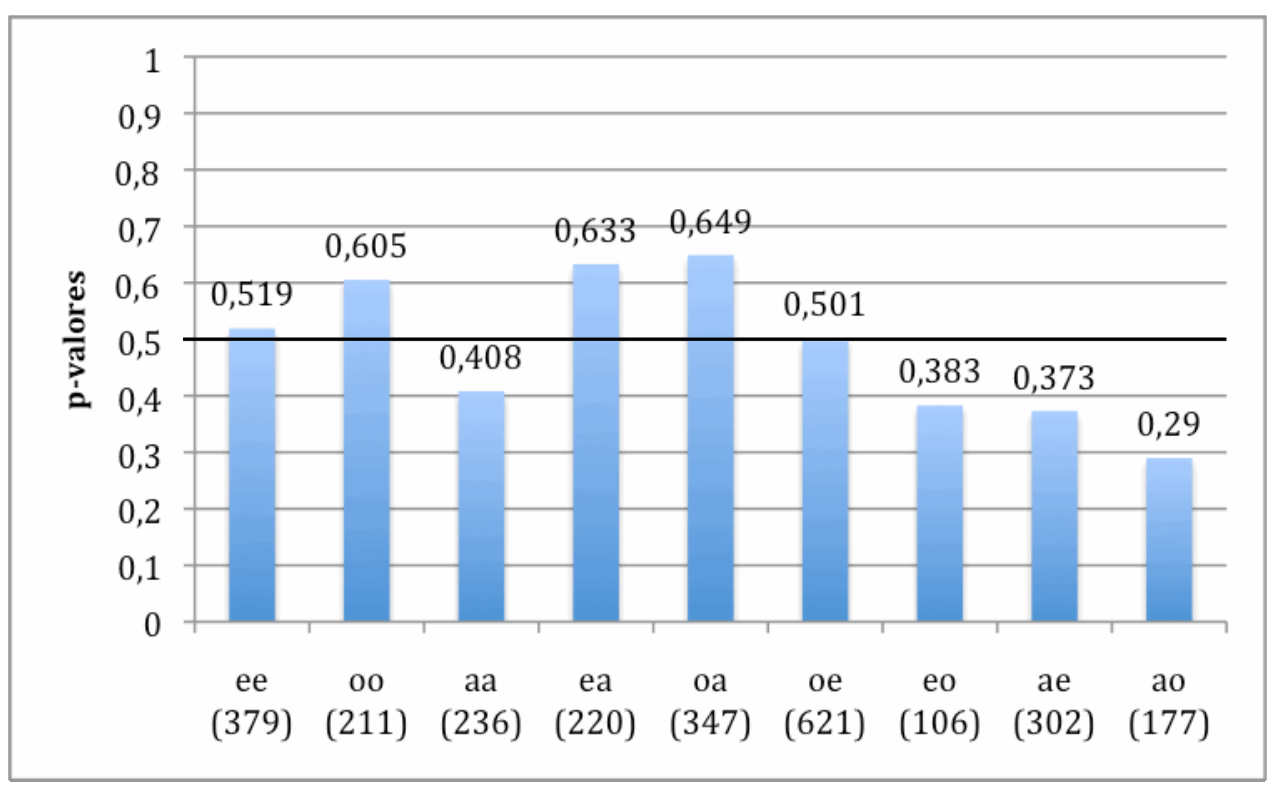

Gráfico 17- Variável Cavidade Oral das Vogais (Capivari)

No que concerne às vogais, foi visto que, se a primeira posição for ocupada por uma dorsal, há um desfavorecimento da queda de sílaba. Para as dorso-labiais em primeira posição do contexto, há um favorecimento se seguida de outra dorso-labial ou de uma dorsal, enquanto que seguida de uma coronal, há uma neutralidade. Finalmente, se a primeira vogal da sequência for uma coronal, há um favorecimento do processo; se seguida de outra coronal, o comportamento parece ser neutro. Para o caso de uma coronal seguida de uma dorso-labial, há um desfavorecimento, resultado que não é confiável, visto que há poucos tokens.

\subsubsection{Estrutura Silábica}

Nesta subseção, apresento os resultados dos tipos de estruturas silábicas do contexto segmental para Capivari: 
Tabela 31 - Variável Estrutura Silábica (Capivari)

\begin{tabular}{|l|c|c|c|c|}
\hline \multicolumn{1}{|c|}{ Estrutura Silábica } & $\mathrm{N}$ & $\mathrm{N}$ total & $\%$ apl & P.R. \\
\hline duas sílabas simples (CV+CV) & 306 & 1613 & 19 & 0,542 \\
\hline duas sílabas com coda ramificada (CVC+CVC) & 3 & 32 & 9,4 & 0,36 \\
\hline duas sílabas com ataque ramificado (CCV+CCV) & 1 & 4 & 25 & 0,406 \\
\hline sílaba simples seguida de outro tipo de estrutura (CV+o) & 91 & 580 & 15,7 & 0,485 \\
\hline sílaba com coda seguida de outro tipo de estrutura (CVC+o) & 18 & 196 & 9,2 & 0,295 \\
\hline sílaba com ataque ramificado + outro tipo de estrutura (CCV+o) & 24 & 135 & 17,8 & 0,479 \\
\hline duas sílabas com outros tipos de estruturas (exceto as acima) (o+o) & 6 & 39 & 15,4 & 0,31 \\
\hline total & 449 & 2599 & 17,3 & \\
\hline
\end{tabular}

input $=0.100 ;$ significância: 0.013

Para contextos com duas sílabas CV, há uma (leve) tendência à queda de sílaba, com $p=0,542$; um contexto com a primeira sílaba CV seguida de sílabas de outros tipos de estruturas (que não CV, CCV e CVC), não há efeito no processo, já que o peso relativo está próximo ao neutro (cf. $\mathrm{CV}+\mathrm{o} p=0,485$ ). O número de tokens para $\mathrm{CCV}+\mathrm{CCV}$ (apenas 4 ) foi muito baixo e não podemos tirar conclusões para este fator; por outro lado, o resultado de sílabas com ataque ramificado pode ser observado no fator CCV+outros, que tem um número mais elevado de tokens (135), com $p=0,479$, perto do ponto neutro. Sílabas com coda CVC seguidas de outros tipos de estruturas influenciam de modo a desfavorecer o processo, com $p=0,295$ e, com relação a duas sílabas que tenham coda CVC+CVC, não podemos tirar conclusões, já que a frequência foi baixa ( $\mathrm{N}=3 / 32$ dados). Finalmente, sílabas com estruturas diferentes entre si (e diferentes de CV, CCV ou CVC) tiveram baixa frequência, com $N=6 / 39$, e não há como interpretar poucos dados (cf. sequência $o+o$ na Tabela 31). 


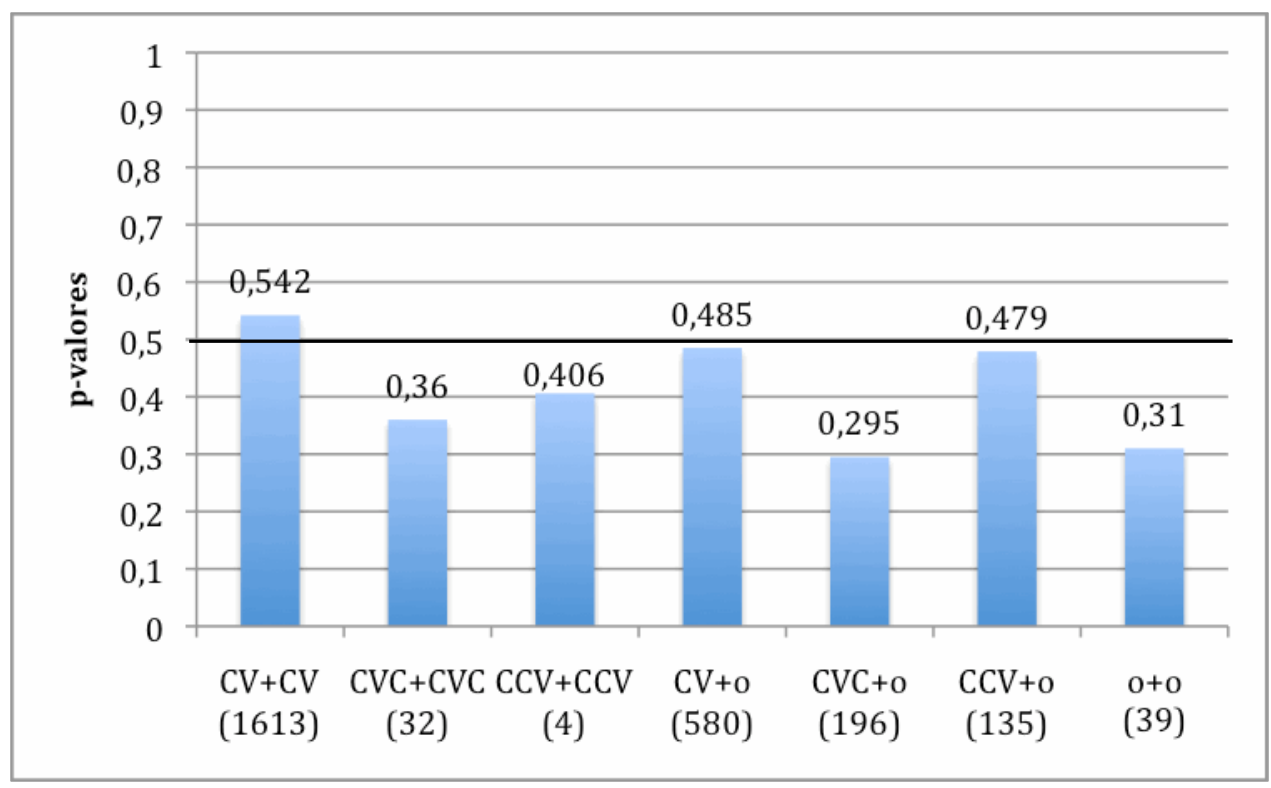

Gráfico 18- Variável Estrutura Silábica (Capivari)

Para o fator $C C V+C C V$, nada podemos afirmar, uma vez que os dados são poucos $(\mathrm{N}=1 / 4)$. Contudo, podemos observar o comportamento de sílabas com ataque ramificado no fator CCV+outros, e podemos verificar que estes tipos de sílabas se comportam de modo semelhante àquele de sílabas simples (seguidas de outros tipos de estruturas); o contexto com duas sílabas simples favorece (levemente) a queda de sílaba; e sílabas com coda desfavorecem a queda de sílaba. Finalmente, contextos de duas sílabas que tenham estruturas diferentes entre si não foram interpretados, devido ao baixo número de tokens.

\subsubsection{Métrica}

Com relação aos acentos da primeira sílaba e da seguinte, obtivemos as seguintes frequências e pesos relativos: 
Tabela 32 - Variável Métrica (Capivari)

\begin{tabular}{|c|c|c|c|c|}
\hline Métrica & $\mathrm{N}$ & $\mathrm{N}$ total & \%apl & P.R. \\
\hline lapso de 3 sílabas $(\mathrm{x} \bullet \bullet \# \bullet)$ & 5 & 11 & 45,5 & 0,614 \\
\hline lapso de 3 sílabas (a última é um clítico) $(x \cdot \cdots \#$ c) & 13 & 38 & 34,2 & 0,687 \\
\hline duas fracas entre um acento 1ário e um acento 2 ário $(x \cdot \bullet \#$ y) & 0 & 3 & 0 & - \\
\hline duas fracas entre duas fortes $(x \cdot \bullet \# x)$ & 4 & 32 & 12,5 & 0,469 \\
\hline lapso de 2 sílabas $(x \cdot \# \bullet)$ & 70 & 378 & 18,5 & 0,548 \\
\hline lapso de 2 sílabas (a última é um clítico) $(x \cdot \#$ c) & 218 & 894 & 24,4 & 0,61 \\
\hline uma fraca entre um acento 1 ário e um acento 2ário $(x \cdot \#$ y) & 26 & 107 & 24,3 & 0,67 \\
\hline uma fraca entre duas fortes $(x \cdot \# x)$ & 113 & 1136 & 9,9 & 0,376 \\
\hline total & 449 & 2599 & 17,3 & \\
\hline
\end{tabular}

input $=0.100 ;$ significância: 0.013

Como podemos observar no terceiro fator apresentada na Tabela 32, houve knockout com contextos em que a primeira palavra é um dátilo e a primeira sílaba da segunda palavra é portadora de acento secundário, com $\mathrm{N}=0 / 3$. Assim, este fator foi descartada da rodada. Os contextos que favorecem a queda de sílaba são aqueles em que há lapsos acentuais de duas sílabas, como em [x * • e e [x * \# c], com p=0,548 e 0,61, respectivamente. É interessante notar que, se houver uma fraca entre uma forte e uma sílaba com acento secundário $[x \cdot \# y]$, há também um favorecimento na aplicação do processo, com $p=0,67$. Para contextos em que a implementação da queda de sílaba resulte choque de acentos $[\mathrm{x} \cdot \# \mathrm{x}]$, o processo é evitado, com $\mathrm{p}=0,376$.

Houve três sequências métricas com dátilos (sem knockouts), quais sejam: uma sílaba forte seguida de um lapso de 3 sílabas $[\mathrm{x} \cdot * \# \cdot$ ], duas fracas entre uma sílaba forte e um clítico $[\mathrm{x} \bullet \# \mathrm{c}]$ e duas fracas entre uma forte e uma sílaba com acento secundário $[\mathrm{x} \bullet \bullet$ \# y]. Destes contextos métricos, não podemos tirar conclusões, devido ao pouco número de tokens $(\mathrm{N}=5 / 11, \mathrm{~N}=13 / 38$ e $\mathrm{N}=0 / 3$, respectivamente). 


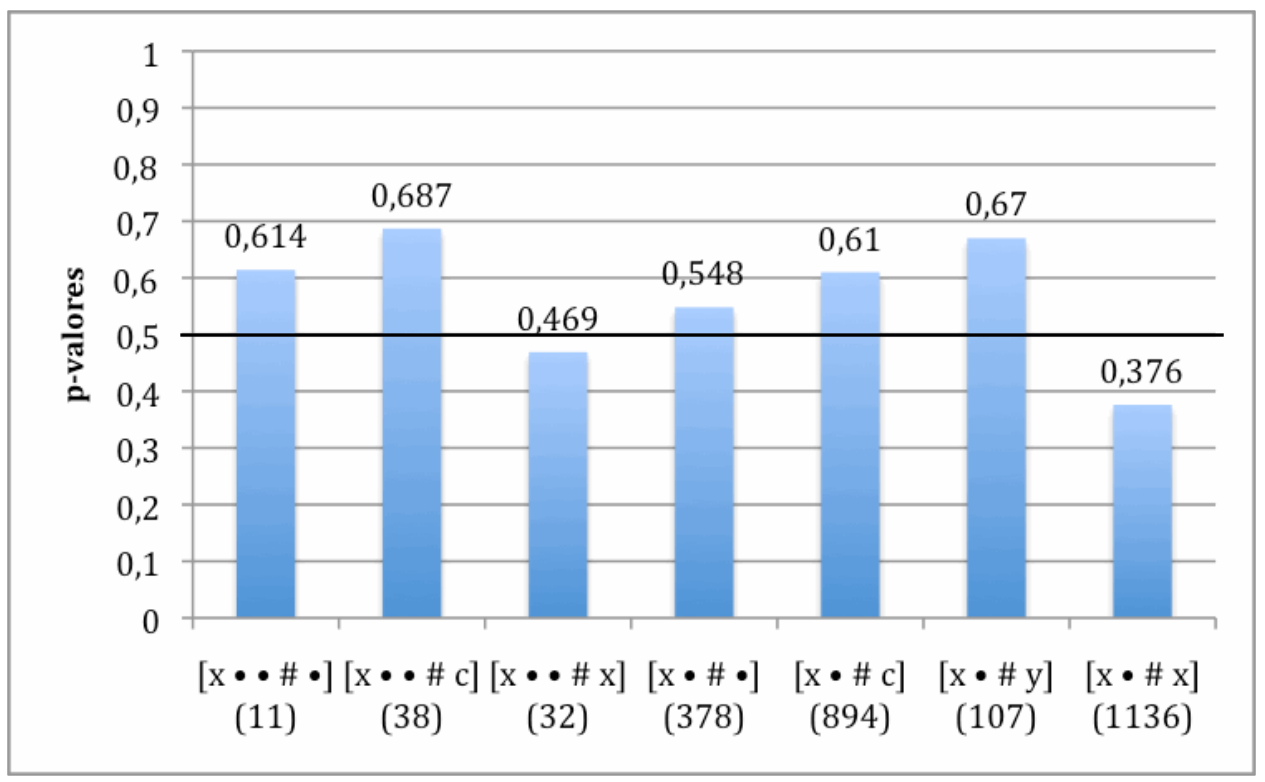

Gráfico 19- Variável Métrica (Capivari)

Pudemos verificar com esta variável que três estruturas métricas tendem à queda de sílaba: i) uma sílaba forte seguida de duas fracas; ii) uma fraca entre uma forte e um clítico; e iii) uma fraca entre uma sílaba com acento primário e outra com acento secundário. Vimos também que, se o resultado da aplicação do processo for ruim (isto é, se o apagamento de sílaba resultar em choque acentual), a queda de sílaba é desfavorecida. Com relação aos dátilos, os resultados encontrados não são consistentes, pois as frequências são baixas.

\subsubsection{Prosódia}

Verificamos que os níveis prosódicos interferem na queda de sílaba em Capivari da maneira representada na tabela abaixo:

Tabela 33 - Variável Prosódia (Capivari)

\begin{tabular}{|c|c|c|c|c|}
\hline Prosódia & N & N total & $\%$ apl & P.R. \\
\hline entre frases entonacionais (entre Is) & 76 & 814 & 9,3 & 0,444 \\
\hline entre frases fonológicas (entre Фs) & 150 & 624 & 24 & 0,571 \\
\hline entre grupos clíticos (dentro de $\Phi$ reestr.) (entre Cs) & 223 & 1161 & 19,2 & 0,501 \\
\hline total & 449 & 2599 & 17,3 & \\
\hline
\end{tabular}

input $=0.100 ;$ significância: 0.013

Como se vê na Tabela 33, os resultados para Prosódia não estão tão polarizados: 
entre sentenças, o processo é desfavorecido, com $p=0,444$; entre grupos clíticos, o peso relativo é neutro $(p=0,501)$, enquanto que entre frases fonológicas há uma leve tendência à queda de sílaba, com $p=0,571$.

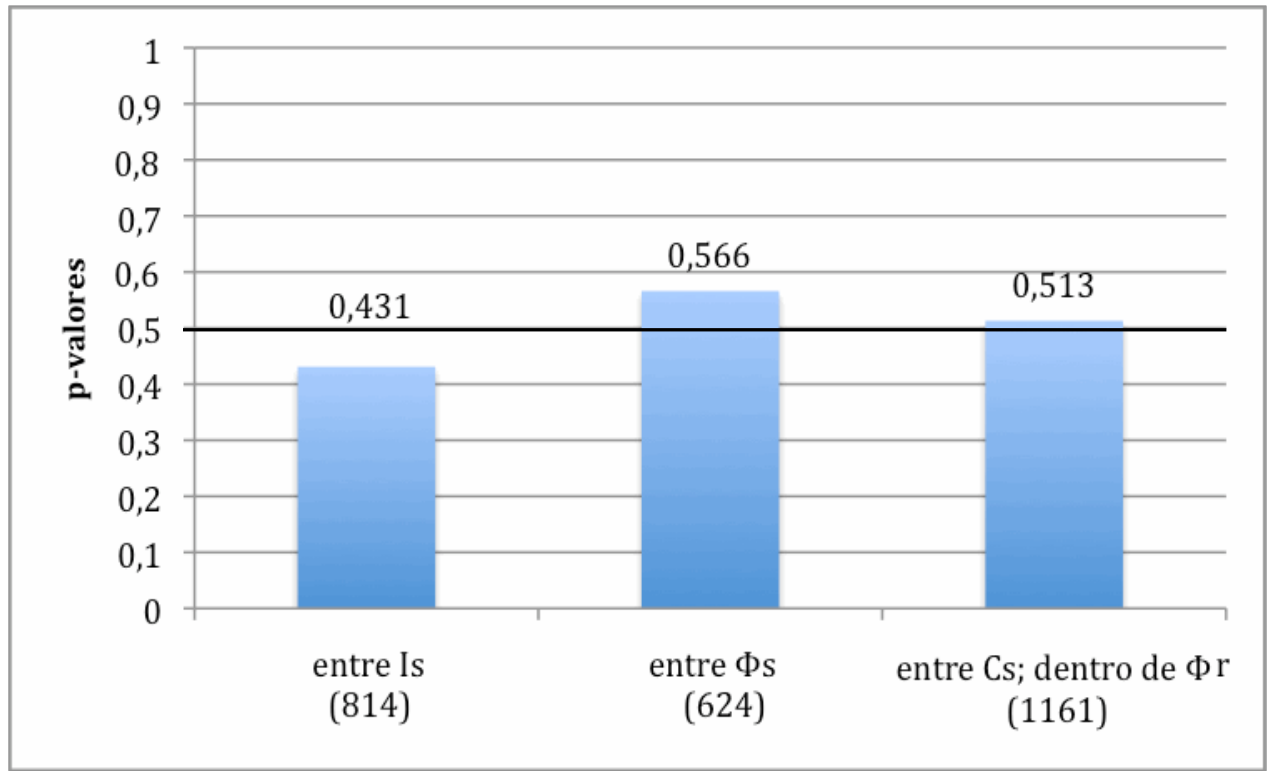

Gráfico 20- Variável Prosódia (Capivari)

Se o contexto segmental estiver entre sentenças, o processo é um pouco desfavorecido; entre grupos clíticos (e dentro de frase fonológica reestruturada), não há propensão; por fim, a queda de sílaba é levemente favorecida na fronteira entre duas frases fonológicas.

\subsubsection{Número de Sílabas}

Para o tamanho da palavra, obtivemos as seguintes frequências e pesos relativos: 
Tabela 34 - Variável Número de Sílabas (Capivari)

\begin{tabular}{|c|c|c|c|c|}
\hline Número de Sílabas & $\mathrm{N}$ & $\mathrm{N}$ total & \%apl & P.R. \\
\hline 2 sílabas $(2 \sigma s)$ & 241 & 1508 & 16 & 0,46 \\
\hline 3 sílabas ( $3 \sigma s)$ & 124 & 717 & 17,3 & 0,519 \\
\hline 4 sílabas ou mais ( 4 бs ou + ) & 84 & 374 & 22,5 & 0,624 \\
\hline total & 449 & 2599 & 17,3 & \\
\hline
\end{tabular}

input $=0.100 ;$ significância: 0.013

Notamos que à medida que o número de sílabas da palavra aumenta, pode aumentar também a tendência à queda; no entanto, os pesos relativos não são tão polarizados para esta variável: palavras com 2 sílabas desfavorecem levemente, com $p=0,46$; palavras de 3 sílabas não interferem, já que o peso relativo está próximo ao neutro, $p=0,519$; e palavras que tenham 4 sílabas ou mais favorecem o processo, com $p=0,624$.

Apresento no gráfico abaixo os resultados para Número de Sílabas da palavra sujeita à queda:

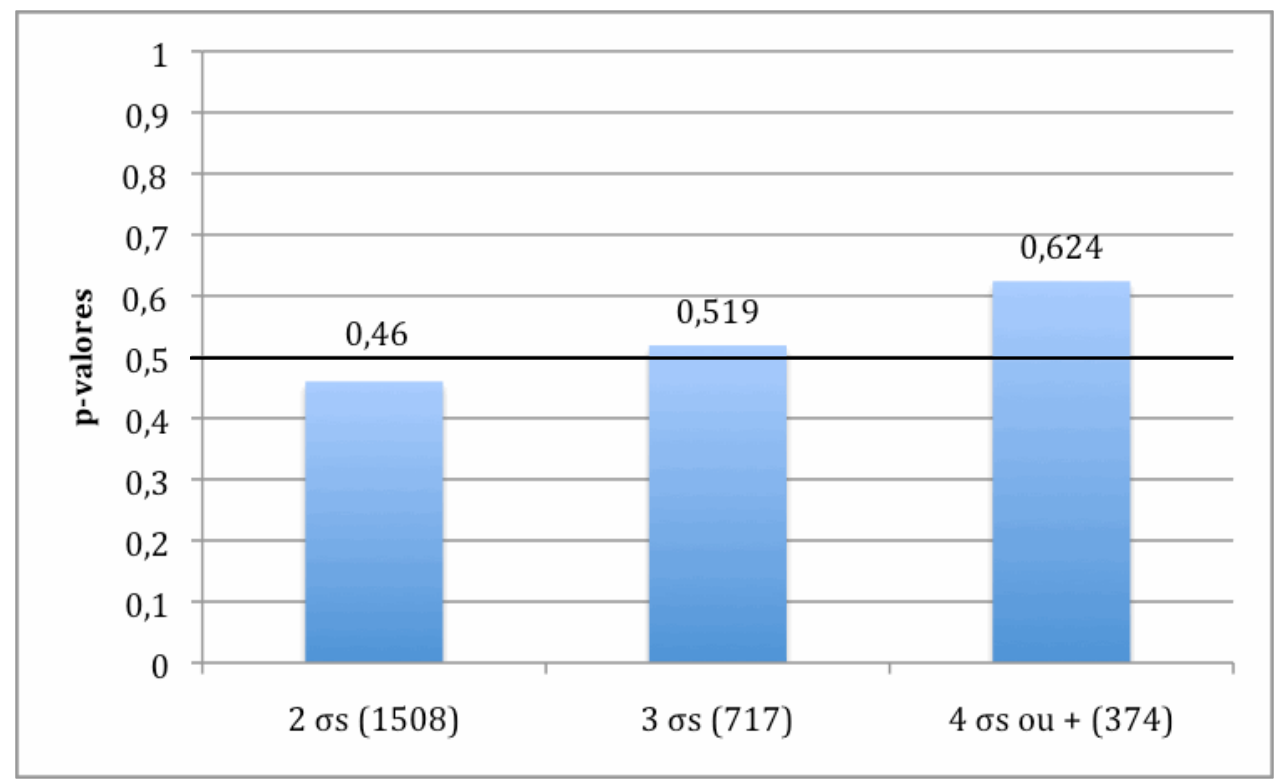

Gráfico 21 - Variável Número de Sílabas (Capivari)

Com esta variável, pudemos verificar que a tendência à queda aumenta à medida que a palavra aumenta de tamanho; ainda, vemos que os resultados não estão tão polarizados. Palavras com 2 sílabas inibem um pouco o processo. 


\subsubsection{Frequência de Uso de Palavras}

Esta variável não foi selecionada para Capivari, o que parece indicar que, seja a palavra muito usada ou seja rara, não há nenhum efeito para os capivarianos. Apresento abaixo as frequências obtidas:

Tabela 35 - Variável Frequência de Uso de Palavras (Capivari)

\begin{tabular}{|c|c|c|c|}
\hline Frequência de Uso das Palavras & N & N total & $\%$ apl \\
\hline mais de 20.900 ocorrências no ASPA (alta) & 235 & 1378 & 17,1 \\
\hline de 10.451 a 20.899 ocorrências no ASPA (média) & 82 & 369 & 22,2 \\
\hline menos de 10.450 ocorrências no ASPA (baixa) & 124 & 793 & 15,6 \\
\hline total & 441 & 2540 & 17,4 \\
\hline
\end{tabular}

Podemos observar na Tabela 35 que as porcentagens para os fatores alta (com mais de 20.900 ocorrências no ASPA) e baixa (com menos de 10.450 ocorrências) são semelhantes: $17,1 \%$ para alta frequência de uso e 15,6\% para baixa frequência de uso. $A$ porcentagem foi maior com palavras de frequência média (que estão entre 10.451 e 20.899 ocorrências no ASPA), com 22,2\% de aplicação do processo.

Resumidamente, palavras de alta e baixa frequências têm uma porcentagem de aplicação parecidas, e são menores do que para palavras de frequência média.

\subsection{As variáveis sociais em Capivari}

Nesta seção apresento as análises das frequências ${ }^{99}$ das variáveis externas de Capivari - Escolaridade (cf. 6.2.1), Gênero (ver 6.2.2) e Faixa Etária (cf. 6.2.3).

\subsubsection{Escolaridade}

Se na rodada geral há uma diferença de aplicação da regra, em Capivari a Escolaridade parece não importar:

99 Lembramos que utilizamos as frequências dos grupos de fatores externos Escolaridade, Gênero e Faixa Etária, e não os p-valores, porque não foram selecionados pelo programa. 
Tabela 36 - Frequências da variável Escolaridade (Capivari)

\begin{tabular}{|c|c|c|c|}
\hline Escolaridade & $\mathrm{N}$ & $\mathrm{N}$ total & \%apl \\
\hline até fundamental & 211 & 1227 & 17,2 \\
\hline ensino superior & 238 & 1372 & 17,3 \\
\hline total & 449 & 2599 & \\
\hline
\end{tabular}

Como vemos na tabela acima, a frequência de aplicação de queda de sílaba das pessoas que estudaram até o ensino fundamental é muito parecida com a de pessoas que cursaram ensino superior. Uma vez que há uma boa distribuição de tokens, concluímos que a escolaridade dos informantes não importa para a regra de queda de sílaba em Capivari.

\subsubsection{Gênero}

Em Capivari, há uma diferença na aplicação do processo se considerarmos o gênero dos informantes, como representado na tabela abaixo:

Tabela 37 - Frequências da variável Gênero (Capivari)

\begin{tabular}{|c|c|c|c|}
\hline Gênero & $\mathrm{N}$ & $\mathrm{N}$ total & $\%$ apl \\
\hline masculino & 278 & 1285 & 21,6 \\
\hline feminino & 171 & 1314 & 13 \\
\hline total & 449 & 2599 & \\
\hline
\end{tabular}

Também para esta variável Gênero, os dados estão distribuídos de modo ortogonal, e podemos observar que os capivarianos aplicam a queda de sílaba mais do que as capivarianas, já que aqueles têm $21,6 \%$ de implementação em oposição aos $13 \%$ das mulheres.

\subsubsection{Faixa Etária}

Da mesma forma que para as variáveis Escolaridade e Gênero, a distribuição ortogonal dos dados para Faixa Etária torna os resultados confiáveis. Como podemos observar na tabela abaixo, as porcentagens dos dois fatores estão próximos: 
Tabela 38 - Frequências da variável Faixa Etária (Capivari)

\begin{tabular}{|c|c|c|c|}
\hline Faixa etária & $\mathrm{N}$ & $\mathrm{N}$ total & \%apl \\
\hline de 20 a 35 & 268 & 1359 & 19,7 \\
\hline mais de 50 & 181 & 1240 & 14,6 \\
\hline total & 449 & 2599 & \\
\hline
\end{tabular}

Apesar da diferença na aplicação, os mais jovens com $19,7 \%$ e os mais velhos com $14,6 \%$ de implementação do processo, notamos que esta diferença é pequena. Assim, a aplicação de queda de sílaba com relação à Faixa Etária dos informantes parece não ser uma variável relevante para o processo em Capivari.

\subsubsection{Informantes}

Na subseção 5.3.2.4, apresentamos os pesos relativos e as frequências para a variável Informantes da rodada geral. Uma vez que as frequências são as mesmas para cada indivíduo, passamos a tratar nesta subseção dos pesos relativos para os 24 capivarianos, apresentados no gráfico que segue:

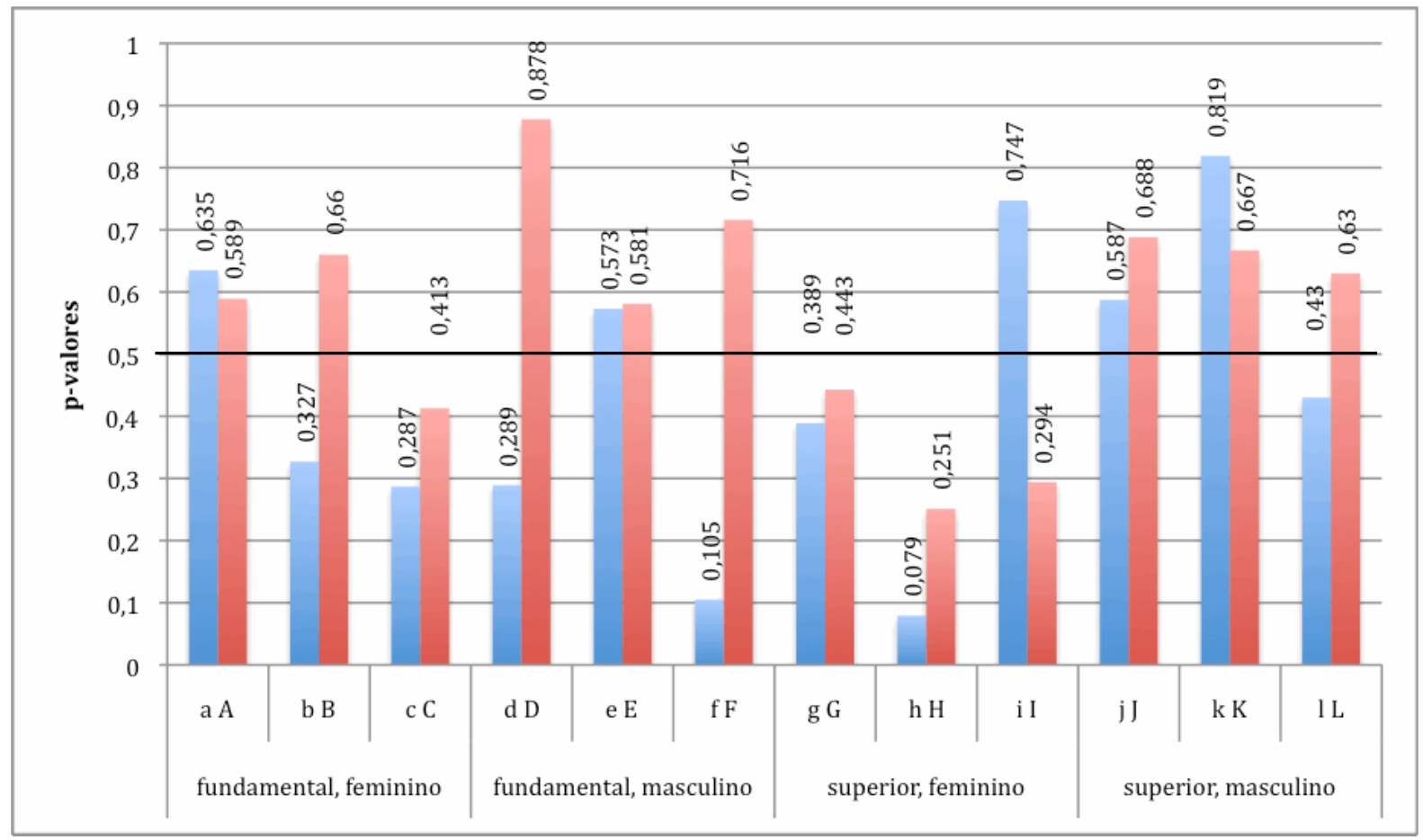

Gráfico 22- Pesos relativos da variável Informante (Capivari) 
No Gráfico 22, os fatores em letras minúsculas representam os informantes com idade acima de 50 anos, enquanto que as maiúsculas indicam os informantes que têm entre 20 e 35 anos.

Houve 13 informantes que favoreceram a queda de sílaba $-D, i$ e $k$ tiveram os pesos relativos mais altos $(p=0,878, p=0,747$ e 0,819 , respectivamente). Os informantes que desfavorecem a queda de sílaba são 7, e apenas um deles tem idade na faixa de 20 a 35 anos - a informante $H$, com $p=0,251$. Os fatores que não têm nenhuma tendência são 4 e, dentre elas, apenas $C$ tem ensino fundamental, com $p=0,413$; os outros informantes $\mathrm{G}, \mathrm{g}$ e I fizeram faculdade (os pesos relativos para estas pessoas são, respectivamente: $p=0,443, p=0,389$ e 0,43$)$. 


\section{CAPÍTULO VII}

\section{Em Campinas}

Para Campinas, também foram 24 informantes, e a distribuição dos dados analisados está apresentada a seguir:

Tabela 39 - Resultados de aplicação de queda de sílaba em Campinas

\begin{tabular}{|c|c|c|}
\hline Campinas & $\mathrm{N}$ & $\%$ \\
\hline aplicação & 737 & 24,3 \\
\hline não aplicação & 2292 & 75,7 \\
\hline total & 3029 & \\
\hline
\end{tabular}

Da mesma forma que na rodada geral e na de Capivari, rodamos todos as variáveis unidas, inclusive aquelas do contexto segmental. Em seguida, rodamos cada um dos grupos de contexto segmental, opondo-os às outras variáveis linguísticas e sociais, do modo apresentado em (234), no resumo das rodadas na subseção 5.2. Novamente, os resultados para as 5 rodadas foram muito semelhantes, e optamos por descrever a rodada em que todas as variáveis entraram, por ser esta a mais geral.

A única variável do contexto segmental não selecionada para Campinas foi a Cavidade Oral das Consoantes (sem distinguir as consoantes nasais); e a única variável linguística não selecionada para Campinas foi o Número de Sílabas da palavra sujeita à queda; além disso, nenhuma variável externa foi selecionada, com exceção de informantes. Apresento a seguir as variáveis relevantes para a regra de queda de sílaba em Campinas, em duas subseções principais: as linguísticos (cf. 7.1) e as sociais (ver 7.2).

\subsection{As variáveis linguísticas}

Nesta subseção, apresento os resultados de queda de sílaba relacionados efeitos internos à língua: contexto segmental (ver 7.1.1), Estrutura Silábica (cf. 7.1.2), Métrica (ver 7.1.3), Prosódia (cf. 7.1.4), Número de Sílabas (em 7.1.5) e Frequência de Uso de Palavras (cf. 7.1.6). 


\subsubsection{Contexto segmental}

Novamente, separamos os resultados para o contexto segmental nas subseções que seguem (Igualdade de Segmentos na subseção 7.1.1.1, as consoantes em 7.1.1.2 e as vogais em 7.1.1.3), a fim de facilitar a leitura dos dados.

\subsubsection{Igualdade de Segmentos nas Sílabas}

Assim como para Igualdade de Segmentos na rodada geral e na de Capivari, nesta variável de Campinas também rodamos Igualdade de Segmentos somente com sílabas CV, e não entraram 1257 tokens. ${ }^{100}$ Apresento a seguir os resultados desta variável:

Tabela 40 - Variável Igualdade de Segmentos (Campinas)

\begin{tabular}{|l|c|c|c|c|}
\hline \multicolumn{1}{|c|}{ Igualdade de Segmentos } & $\mathrm{N}$ & $\mathrm{N}$ total & $\%$ apl & P.R. \\
\hline os completamente iguais (C=V=) & 60 & 130 & 46,2 & 0,644 \\
\hline Cs iguais, Vs diferentes (C=V\#) & 153 & 443 & 34,5 & 0,572 \\
\hline Cs diferentes em [vozeamento], Vs iguais (C\#vozV=) & 59 & 166 & 35,5 & 0,495 \\
\hline Cs diferentes em [vozeamento], Vs diferentes (C\#vozV\#) & 141 & 410 & 34,4 & 0,499 \\
\hline Cs diferentes em [nasal], Vs iguais (C\#nasalV=) & 11 & 88 & 12,5 & 0,372 \\
\hline Cs diferentes em [nasal], Vs diferentes (C\#nasalV\#) & 52 & 506 & 10,3 & 0,455 \\
\hline Cs diferentes em [ant.distr.], Vs não importam (C\#distr.) & 1 & 29 & 3,4 & 0,1 \\
\hline \multicolumn{1}{|c|}{ total } & 477 & 1772 & 26,9 & \\
\hline
\end{tabular}

input $=0.164 ;$ significância: 0.048

Podemos notar que sílabas completamente iguais favorecem a queda; se as consoantes forem idênticas e as vogais forem diferentes, há uma queda no peso relativo (de 0,644 para sílabas idênticas passa a 0,572), mas o processo continua a ser favorecido. Se as consoantes forem diferentes em vozeamento, os pesos relativos diminuem, ficando perto do ponto neutro e a vogal ser ou não diferente parece não importar (vogais iguais $p=0,495$ e vogais diferentes 0,499 ). Se a diferença entre as consoantes for no traço [nasal] $(p=0,372$ para vogais iguais e 0,455 se forem diferentes), há um desfavorecimento da

100 Esta variável totalizou 1772 dados porque sílabas diferentes de CV não entraram na computação (o mesmo foi feito nas rodadas geral e de Capivari - cf. subseções 5.3.1.1.1 e 6.1.1.1, respectivamente). Os 1257 tokens desprezados foram as seguintes estruturas na primeira posição: 735 com sílabas CV, 179 de sílabas CCV, 269 estruturas CVC, 34 dados com CCVC na primeira sílaba, 1 estrutura CVCC, 33 tokens com sílabas CgV, 2 de estruturas CCgV, 3 CgVC e $1 \mathrm{CVg}$. 
queda de sílaba. Para os contextos em que as consoantes diferem nos traços [anterior, distribuído], não podemos tirar conclusões, já que este fator teve baixa frequência (1/29 tokens). Apresento a seguir os pesos relativos para a variável Igualdade de Segmentos na forma de gráfico:

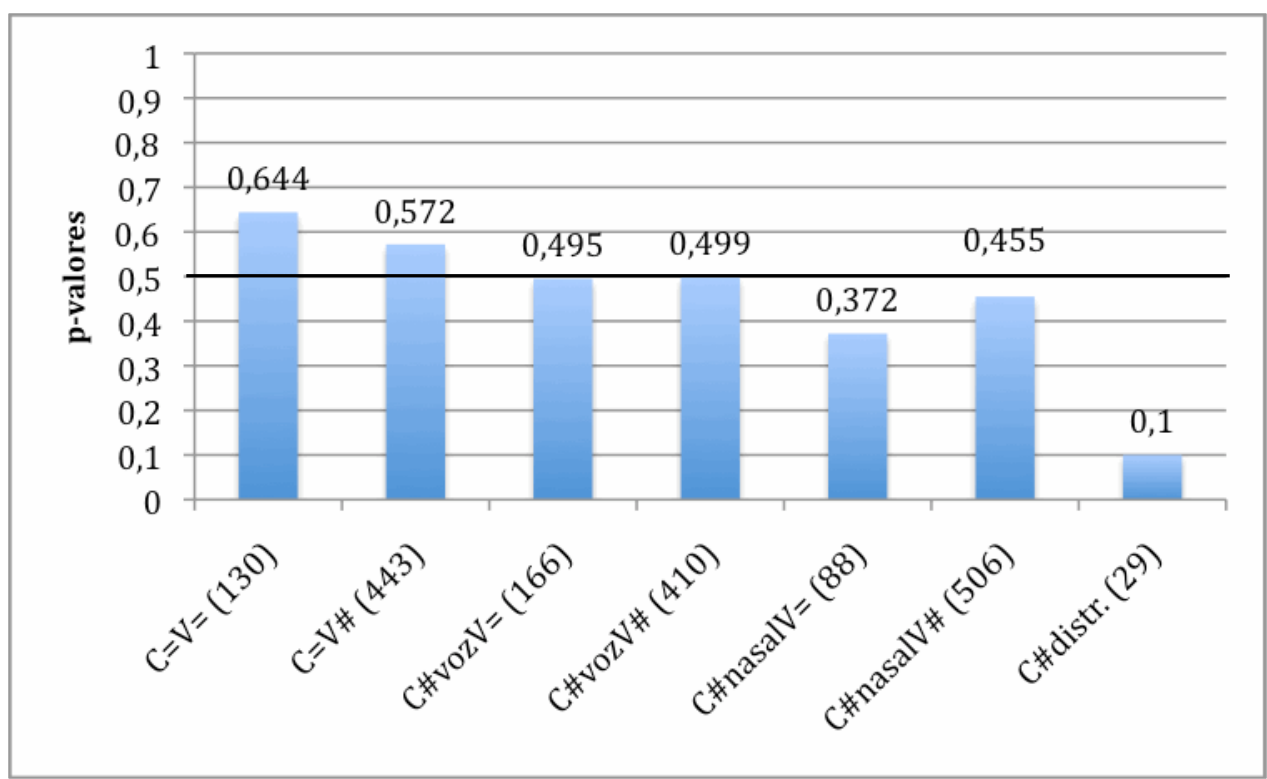

Gráfico 23- Variável Igualdade de Segmentos (Campinas)

Resumidamente, notamos nesta variável que sílabas com consoantes e vogais idênticas tendem à aplicação da queda de sílaba e, se a vogal for diferente, há uma diminuição, mas o favorecimento continua. Se houver uma diferença de [vozeamento] nas consoantes, não há nenhum efeito no processo, já que os pesos relativos estão próximos ao ponto neutro. Se contexto segmental tiver uma consoante nasal (sem importar a ordem da posição da nasal), o processo é desfavorecido. Não pudemos interpretar consoantes diferentes entre si em [anterior, distribuído], já que foi baixo o número de tokens neste fator.

\subsubsection{Cavidade Oral das Consoantes com Distinção de [nasal]}

Para as consoantes, também foram rodadas duas configurações, assim como nas rodadas geral e de Capivari: na primeira, levamos em conta o ponto de C e [contínuo]; na segunda, além da cavidade oral, separamos também as nasais. A configuração que teve relevância foi a segunda, aquela em que foram separadas as nasais, cujos resultados 
apresento abaixo:

Tabela 41 - Variável Cavidade Oral das Consoantes com Distinção do Traço [nasal] (Campinas)

\begin{tabular}{|l|c|c|c|c|}
\hline Cavidade Oral das Consoantes com [nasal] & $\mathrm{N}$ & $\mathrm{N}$ total & \%apl & P.R. \\
\hline 2 consoantes coronal [-contínuo] $(\mathrm{t}+\mathrm{t})$ & 521 & 1399 & 37,2 & 0,644 \\
\hline 2 consoantes coronal [+contínuo] $(\mathrm{s}+\mathrm{s})$ & 44 & 203 & 21,7 & 0,652 \\
\hline 2 consoantes labial [-contínuo] $(\mathrm{p}+\mathrm{p})$ & 4 & 37 & 10,8 & 0,225 \\
\hline 2 consoantes labial [+contínuo] $(\mathrm{f}+\mathrm{f})$ & 10 & 59 & 16,9 & 0,605 \\
\hline 2 consoantes dorsal $(\mathrm{k}+\mathrm{k})$ & 24 & 129 & 18,6 & 0,343 \\
\hline nasais $(\mathrm{n}+\mathrm{n}) \quad 134$ & 1202 & 11,1 & 0,33 \\
\hline \multicolumn{1}{|c|}{ total } & 737 & 3029 & 24,3 & \\
\hline
\end{tabular}

input $=0.164 ;$ significância: 0.048

As coronais têm uma tendência ao processo, sem importar o traço [contínuo], com pesos relativos muito semelhantes (coronais [-contínuo] $p=0,644$ e [+contínuo] $p=0,652$ ). Dorsais e nasais desfavorecem a queda de sílaba em Campinas, com $p=0,343$ e $p=0,33$, respectivamente. Não podemos concluir como é o comportamento das labiais em relação à queda de sílaba em Campinas, uma vez que os números de tokens foram baixos: para labiais [-contínuo], $\mathrm{N}=4 / 37$ e, para labiais [+contínuo] $\mathrm{N}=10 / 59$.

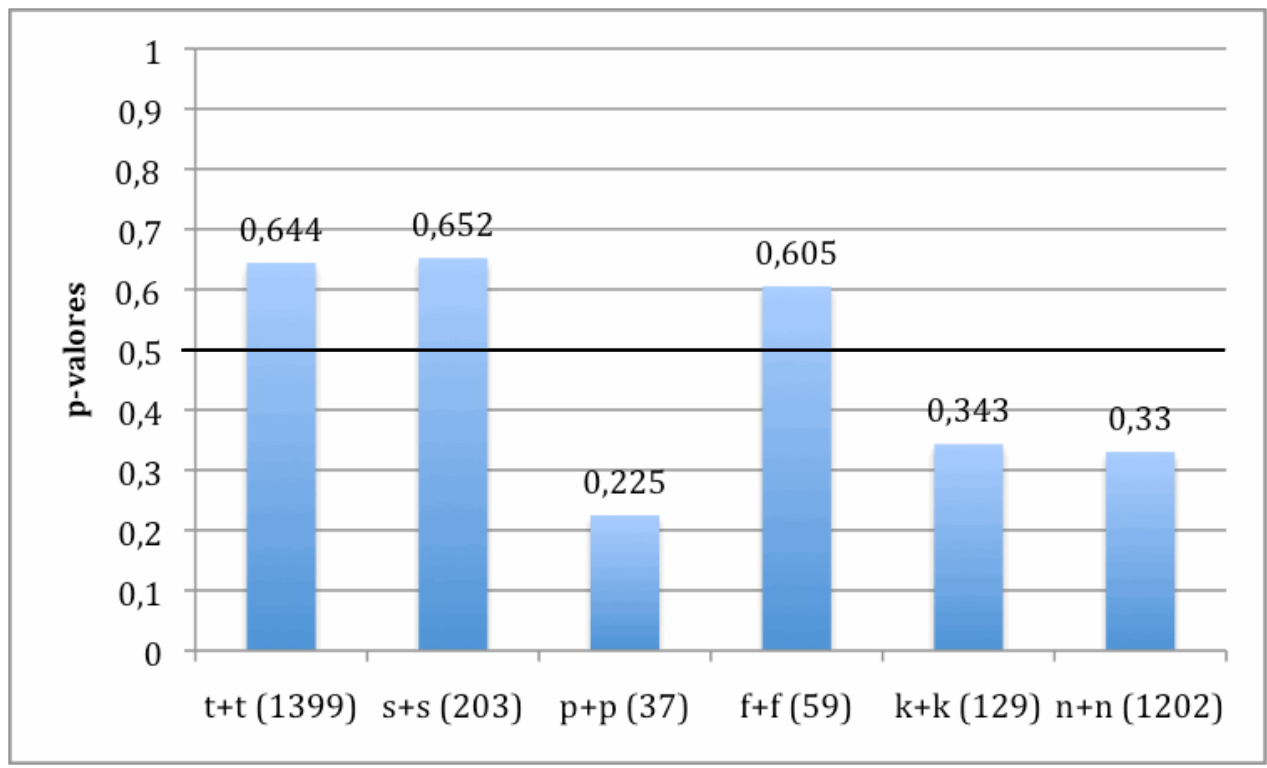

Gráfico 24- Variável Cavidade Oral das Consoantes com Distinção do Traço [nasal] (Campinas) 
Em resumo, vimos que a nasalidade consonantal é um traço muito importante na queda de sílaba: como vimos na rodada geral, em Capivari e em Campinas, somente as variáveis que distinguem estes segmentos foram selecionadas nas três rodadas e, em todas elas, o traço [nasal] da consoante inibe o processo. As coronais orais favorecem a queda de sílaba em Campinas, enquanto que dorsais [-contínuo] desfavorecem o processo; com relação a labiais [ \pm contínuo], não tiramos conclusões, pois os números de dados nos dois fatores [-contínuo] e [+contínuo] foram baixos.

\subsubsection{Cavidade Oral das Vogais}

Apresento a seguir as frequências e pesos relativos obtidos para a variável Cavidade Oral das Vogais:

Tabela 42 - Variável Cavidade Oral das Vogais (Campinas)

\begin{tabular}{|c|c|c|c|c|}
\hline Cavidade Oral das Vogais & $\mathrm{N}$ & $\mathrm{N}$ total & $\%$ apl & P.R. \\
\hline coronal + coronal (ee) & 126 & 440 & 28,6 & 0,571 \\
\hline dorso-labial + dorso-labial (oo) & 75 & 249 & 30,1 & 0,571 \\
\hline dorsal + dorsal (aa) & 35 & 261 & 13,4 & 0,308 \\
\hline coronal + dorsal (ea) & 59 & 220 & 26,8 & 0,569 \\
\hline dorso-labial + dorsal (oa) & 120 & 394 & 30,5 & 0,63 \\
\hline dorso-labial + coronal (oe) & 234 & 763 & 30,7 & 0,593 \\
\hline coronal + dorso-labial (eo) & 24 & 110 & 21,8 & 0,46 \\
\hline dorsal + coronal (ae) & 49 & 391 & 12,5 & 0,328 \\
\hline dorsal + dorso-labial (ao) & 15 & 201 & 7,5 & 0,226 \\
\hline total & 737 & 3029 & 24,3 & \\
\hline
\end{tabular}

input $=0.164 ;$ significância: 0.048

Em Campinas, observamos que duas coronais ou duas dorso-labiais no contexto vocálico tendem à queda (ver contextos ee e oo), fatores que tiveram pesos relativos iguais $(p=0,571)$. Contextos em que a primeira vogal é uma dorsal desfavorecem o processo, sem importar a cavidade oral das vogais seguintes: mesmo se seguida de outra dorsal $(p=0,308$, cf. aa), de uma coronal, com $p=0,328$ (ver ae) ou de uma vogal dorso-labial $(p=0,226$, cf. contexto ao). Há um favorecimento da queda de sílaba se a primeira vogal for uma coronal 
seguida de dorsal, com $p=0,569$ (cf. ea), e há também uma tendência se a primeira vogal for uma dorso-labial - nestes casos, não importam os traços da segunda vogal, com $p=0,63$ quando seguida de dorsal (cf. contexto oa) e $p=0,593$, se seguida de uma coronal (ver contexto oe). A partir destes resultados, notamos que o que parece importar para a implementação do processo é a primeira vogal do contexto: se houver uma coronal ou uma dorso-labial, há uma tendência à queda de sílaba; se a primeira posição for preenchida por uma dorsal, há uma inibição. Assim, para o contexto em que há uma coronal seguida de uma dorso-labial (cf. eo no gráfico), a expectativa é que haja um favorecimento do processo, o que não ocorre: há uma neutralidade, com $p=0,46$. Este resultado inesperado pode ser explicado se observarmos o número de dados neste fator, que foi $\mathrm{N}=24 / 110$, isto é, é o fator que tem o menor número de ocorrências.

Para uma melhor visualização dos pesos relativos, apresento-os a seguir em forma de gráfico:

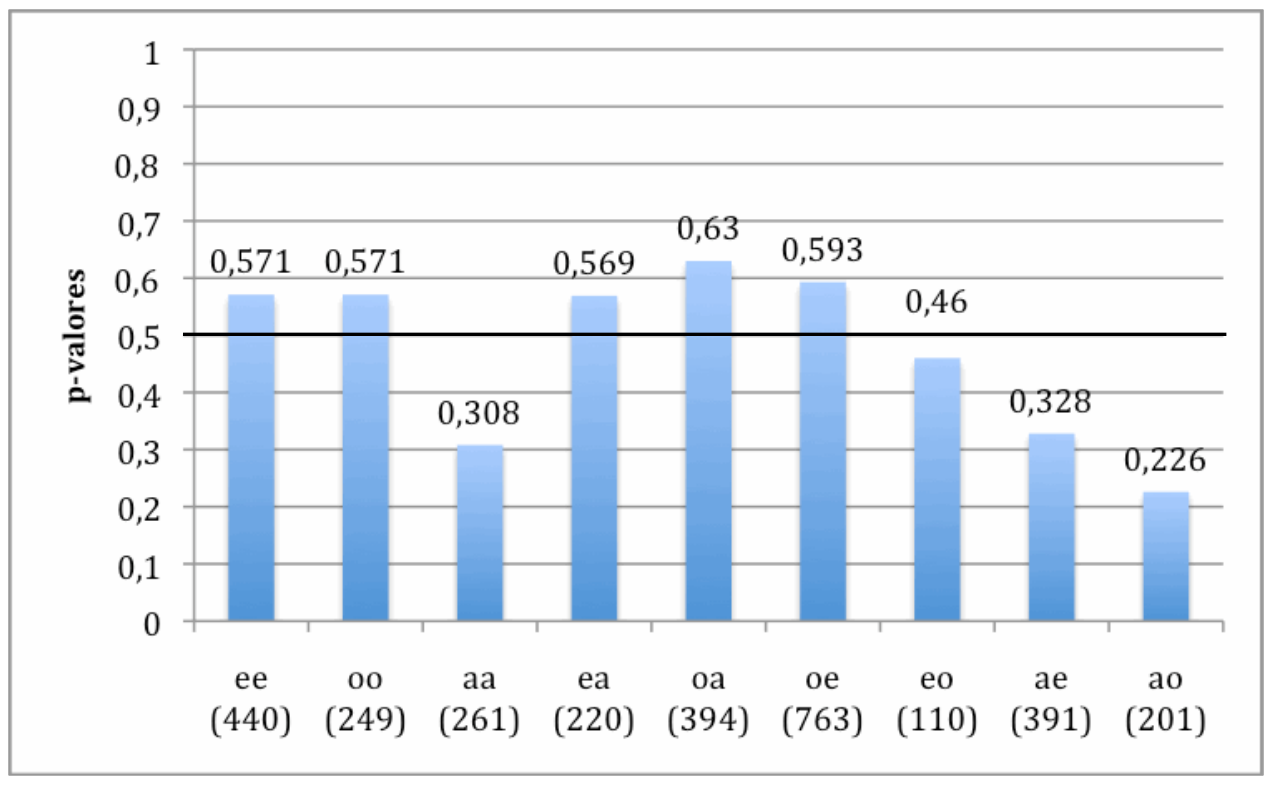

Gráfico 25- Variável Cavidade Oral das Vogais (Campinas)

Para Campinas, pudemos observar que vogais iguais têm uma tendência ao apagamento, com exceção de dorsais, que o inibem. E este comportamento de as dorsais desfavorecerem o processo pode ser verificado também se este tipo de vogal estiver na primeira sílaba, sem importar o que a sucede. Se a vogal coronal ou dorso-labial estiver na 
primeira posição do contexto, o processo é favorecido, sem importar a segunda vogal. Neste caso, há uma exceção de coronal + dorso-labial, de onde nada concluímos, por este fator ter o menor número de ocorrências na variável.

\subsubsection{Estrutura das sílabas}

Os resultados das sequências de estruturas da primeira e da segunda sílabas são dados a seguir:

Tabela 43 - Variável Estrutura Silábica (Campinas)

\begin{tabular}{|l|c|c|c|c|}
\hline \multicolumn{1}{|c|}{ Estrutura Silábica } & $\mathrm{N}$ & $\mathrm{N}$ total & \%apl & P.R. \\
\hline duas sílabas simples (CV+CV) & 477 & 1772 & 26,9 & 0,506 \\
\hline duas sílabas com coda ramificada (CVC+CVC) & 5 & 41 & 12,2 & 0,482 \\
\hline duas sílabas com ataque ramificado (CCV+CCV) & 2 & 4 & 50 & 0,935 \\
\hline sílaba simples seguida de outro tipo de estrutura (CV+o) & 160 & 735 & 21,8 & 0,586 \\
\hline sílaba com coda seguida de outro tipo de estrutura (CVC+o) & 20 & 228 & 8,8 & 0,287 \\
\hline sílaba com ataque ramificado + outro tipo de estrutura (CCV+o) & 58 & 175 & 33,1 & 0,5 \\
\hline duas sílabas com outros tipos de estruturas (exceto as acima) (o+o) & 15 & 74 & 20,3 & 0,213 \\
\hline total & 737 & 3029 & 24,3 & \\
\hline
\end{tabular}

input $=0.164 ;$ significância: 0.048

Um contexto com duas sílabas sujeitas a apagamento que tenham estruturas CV parecem ser neutras à queda de sílaba $(p=0,506)$, enquanto que contextos de sílabas CV seguidas de outros tipos de estruturas favorecem o processo, com $p=0,586$. Contextos em que a primeira sílaba tem ataque ramificado e a segunda tiver outros tipos de estruturas não interferem no processo, já que o peso relativo é 0,5 . Se a sílaba sujeita ao apagamento tiver coda e estiver seguida de outros tipos de estruturas, há um desfavorecimento do processo, com $p=0,287$. Para os contextos de duas sílabas com ataque ramificado $C C V+C C V$, duas sílabas com coda ramificada CVC+CVC e contextos em que as duas sílabas têm estruturas diferentes entre si (ver $0+o$ na tabela), notamos que as ocorrências são muito baixas: $N=2 / 4$ para $\mathrm{CCV}+\mathrm{CCV}$; $\mathrm{N}=5 / 41$ para estruturas silábicas $\mathrm{CVC}+\mathrm{CVC}$; e $\mathrm{N}=15 / 74$ para contextos o+o. Assim, não podemos tirar quaisquer conclusões destes três fatores.

Para uma melhor visualização dos dados, apresento no Gráfico 26 os pesos relativos para esta variável: 


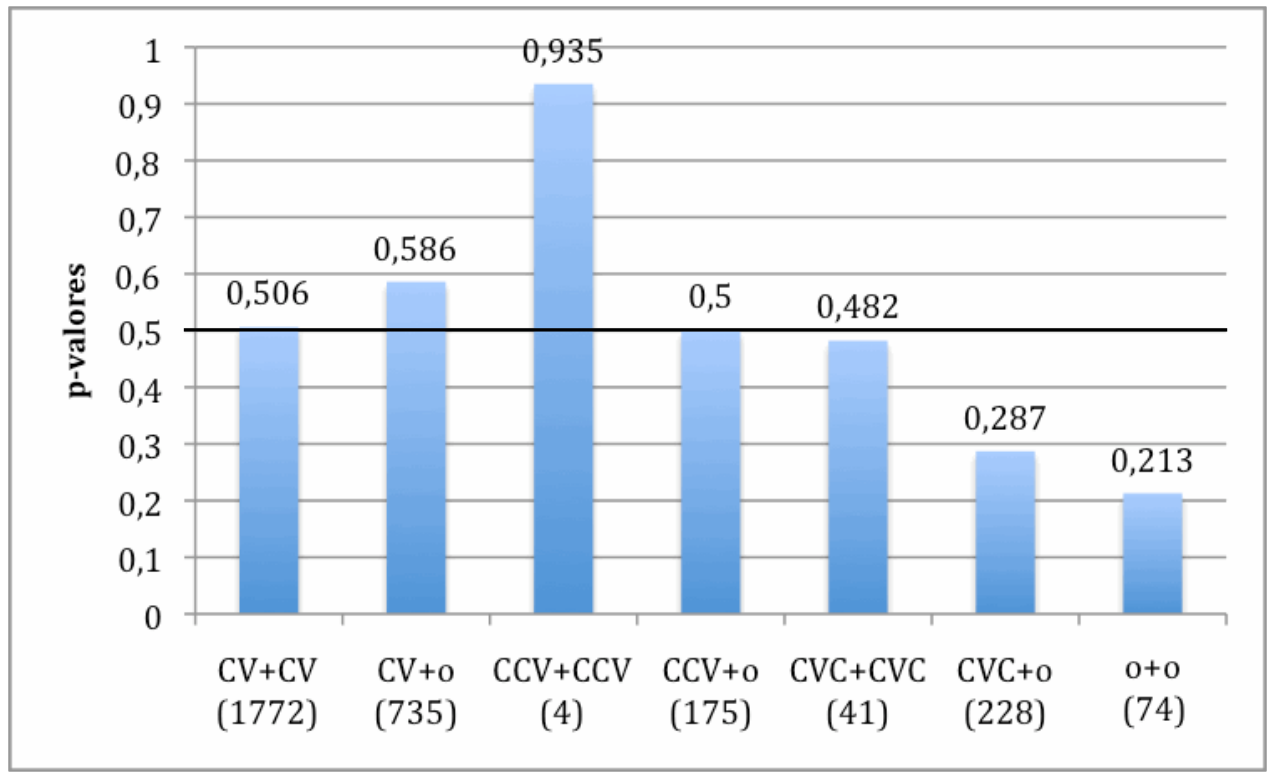

Gráfico 26- Variável Estrutura Silábica (Campinas)

Não pudemos interpretar três fatores desta variável devido à baixa frequência de tokens - contextos CCV+CCV, CVC+CVC e o+o. Contextos em que há uma sílaba simples seguida de uma sílaba com outros tipos de estruturas favorecem o processo, enquanto que sequências com duas sílabas simples $C V+C V$ e com uma sílaba de ataque ramificado seguida de outros tipos de estruturas são inertes ao processo. Sílabas com coda na primeira posição desfavorecem o apagamento quando seguidas de outros tipos de estruturas.

\subsubsection{Métrica}

Para a variável de estrutura métrica, obtivemos os seguintes resultados: 
Tabela 44 - Variável Métrica (Campinas)

\begin{tabular}{|c|c|c|c|c|}
\hline Métrica & $\mathrm{N}$ & $\mathrm{N}$ total & \%apl & P.R. \\
\hline lapso de 3 sílabas $(\mathrm{x} \cdot \bullet \# \cdot)$ & 4 & 15 & 26,7 & 0,78 \\
\hline lapso de 3 sílabas (a última é um clítico) $(\mathrm{x} \cdot \cdots \# \mathrm{c})$ & 18 & 55 & 32,7 & 0,815 \\
\hline duas fracas entre um acento 1 ário e um acento $2^{\text {ário }}(\mathrm{x} \cdots \# \mathrm{y})$ & 1 & 3 & 33,3 & 0,956 \\
\hline duas fracas entre duas fortes $(\mathrm{x} \cdot \cdots \mathrm{\#})$ & 6 & 41 & 14,6 & 0,552 \\
\hline lapso de 2 sílabas $(\mathrm{x} \cdot \# \cdot)$ & 99 & 441 & 22,4 & 0,472 \\
\hline lapso de 2 sílabas (a última é um clítico) $(x \cdot \# c)$ & 406 & 1142 & 35,6 & 0,655 \\
\hline uma fraca entre um acento 1 ário e um acento 2 ário $(x \cdot \# y)$ & 30 & 111 & 27 & 0,613 \\
\hline uma fraca entre duas fortes $(x \cdot \# x)$ & 173 & 1221 & 14,2 & 0,332 \\
\hline total & 737 & 3029 & 24,3 & \\
\hline
\end{tabular}

input $=0.164 ;$ significância: 0.048

Estruturas métricas em que as duas primeiras sílabas são uma forte e uma fraca favorecem a queda de sílaba, quando seguidas de um clítico fonológico $(p=0,655)$ ou de uma sílaba com acento secundário $(p=0,613)$. Contextos em que há uma sílaba forte seguida de duas sílabas fracas não interferem, com um peso relativo próximo ao ponto neutro $(p=0,472)$. Choques acentuais são evitados também em Campinas, com $p=0,332$ para o fator $[\mathrm{x} \cdot \# \mathrm{x}$ ]. Com relação a contextos com dátilos na primeira posição, não podemos tirar quaisquer conclusões, uma vez que foram poucas ocorrências: estruturas métricas $[\mathrm{x} \cdot \bullet$ ] seguidas de uma sílaba forte, $N=6 / 41$; seguidas de uma sílaba com acento secundário, $N=1 / 3$; se a segunda sílaba do contexto segmental for um clítico, $N=18 / 55$; e se a primeira sílaba da segunda palavra for fraca, 4/15 ocorrências. No gráfico abaixo, estão os pesos relativos para a variável Métrica: 


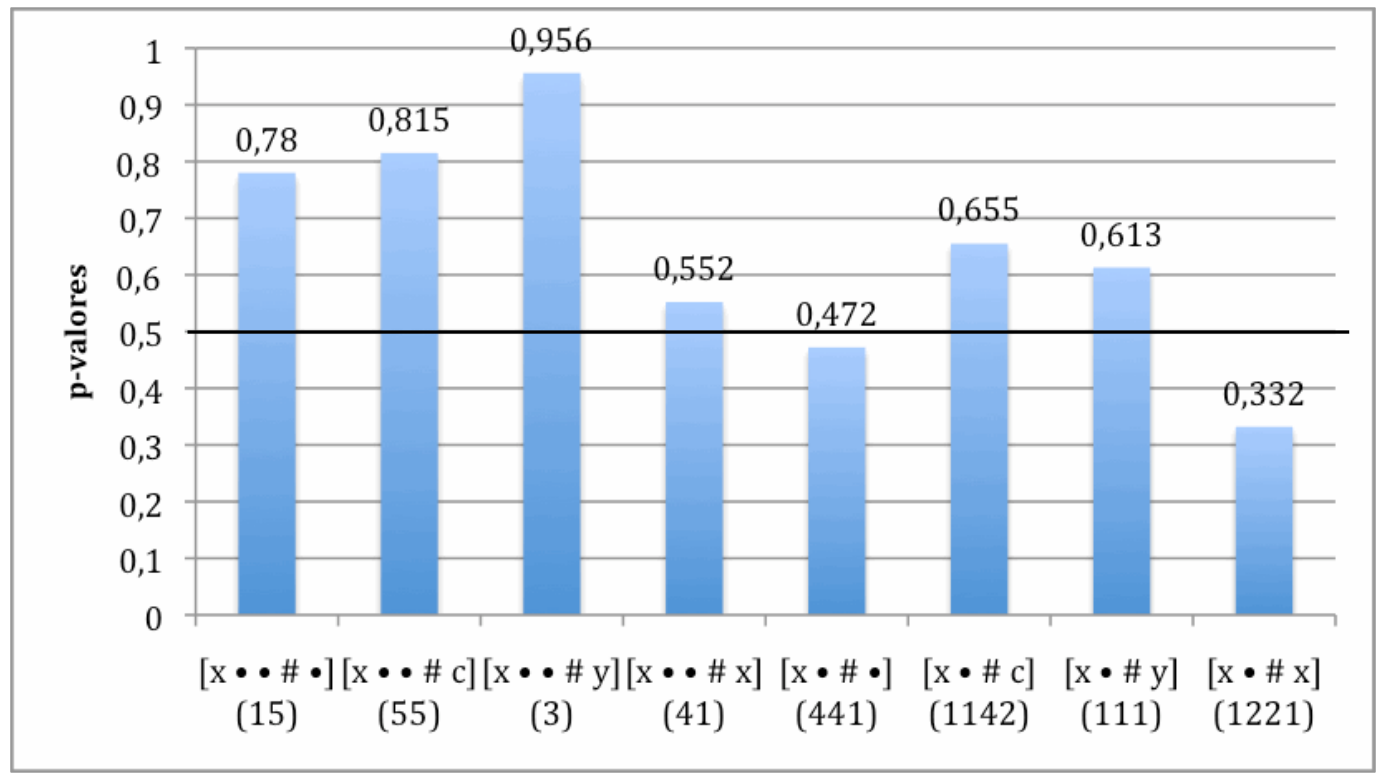

Gráfico 27- Variável Métrica (Campinas)

Desta variável, pudemos verificar que os dois contextos de [sílaba forte + uma fraca + um clítico] e sequências constituídas de [sílaba forte + fraca + acento secundário] favorecem a queda de sílaba; sequências [forte + fraca + fraca] são neutras; e contextos [ $x$ - \# x ] que resultam em choques acentuais são evitados. Há poucos tokens com dátilos, e nada podemos concluir dos quatro fatores que têm este tipo de estrutura acentual na primeira palavra.

\subsubsection{Prosódia}

Os resultados de queda de sílaba relacionados à hierarquia prosódica são parecidos com aqueles da rodada geral e de Capivari, como se verifica a seguir:

Tabela 45 - Variável Prosódia (Campinas)

\begin{tabular}{|c|c|c|c|c|}
\hline Prosódia & $\mathrm{N}$ & $\mathrm{N}$ total & $\% \mathrm{apl}$ & P.R. \\
\hline entre frases entonacionais (entre Is) & 126 & 880 & 14,3 & 0,45 \\
\hline entre frases fonológicas (entre $\Phi$ s) & 208 & 689 & 30,2 & 0,552 \\
\hline entre grupos clíticos (dentro de $\Phi$ reestr.) (entre Cs) & 403 & 1460 & 27,6 & 0,505 \\
\hline total & 737 & 3029 & 24,3 & \\
\hline
\end{tabular}

input $=0.164 ;$ significância: 0.048

A queda de sílaba é levemente favorecida entre frases fonológicas, com $p=0,552$; há 
neutralidade se as palavras do contexto de queda de sílaba estiverem entre fronteiras de grupos clíticos (ou dentro de frase fonológica reestruturada), com $p=0,505$; e entre sentenças, o processo é um pouco desfavorecido $(p=0,45)$.

Os pesos relativos para a variável Prosódia estão apresentados no gráfico:

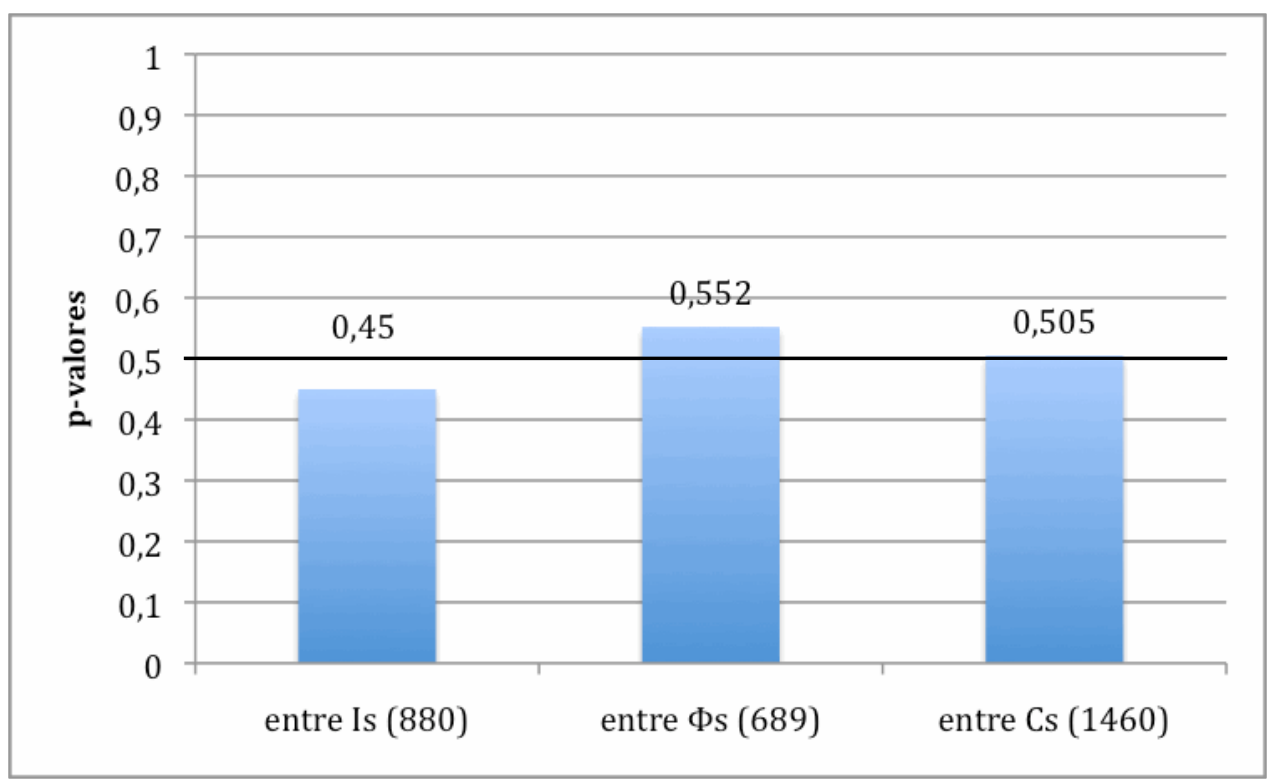

Gráfico 28- Variável Prosódia (Campinas)

Podemos concluir que a Prosódia interfere levemente na queda de sílaba, já que há um pouco de desfavorecimento entre frases entonacionais, uma pequena tendência em fronteira entre frases fonológicas e uma neutralidade se a fronteira for de grupos clíticos (e, neste caso, também dentro de frase fonológica).

\subsubsection{Número de Sílabas}

A variável de tamanho de palavra não foi selecionada na rodada de Campinas em que entraram todos as variáveis. No entanto, o Número de Sílabas foi selecionado nas rodadas 2,4 e 5, isto é, com os seguintes contextos segmentais: Igualdade de Segmentos, Consoantes (com distinção de nasais) e Vogais (cf. o resumo das rodadas em (234), na subseção 5.2). Apresento abaixo as frequências e os pesos relativos da rodada 2:101 
Tabela 46 - Variável Número de Sílabas na rodada 2 (Campinas)

\begin{tabular}{|c|c|c|c|c|}
\hline Número de sílabas & $\mathrm{N}$ & $\mathrm{N}$ total & \%apl & rodada 2 \\
\hline $2 \sigma s$ & 421 & 1742 & 24,2 & 0,474 \\
\hline $3 \sigma s$ & 200 & 835 & 24 & 0,5 \\
\hline 4 os ou mais & 116 & 452 & 25,7 & 0,6 \\
\hline total & 737 & 3029 & & \\
\hline
\end{tabular}

input $=0.183 ;$ significância: 0.007

Como podemos observar, o número de sílabas da palavra sujeita ao apagamento é diretamente proporcional à aplicação do processo: dissílabos desfavorecem (levemente), com $p=0,474$; trissílabos não interferem $(p=0,5)$; e palavras com 4 sílabas ou mais tendem ao apagamento, com $\mathrm{p}=0,6$.

Para uma melhor visualização dos resultados, apresento abaixo o gráfico com os pesos relativos obtidos na rodada 2 :

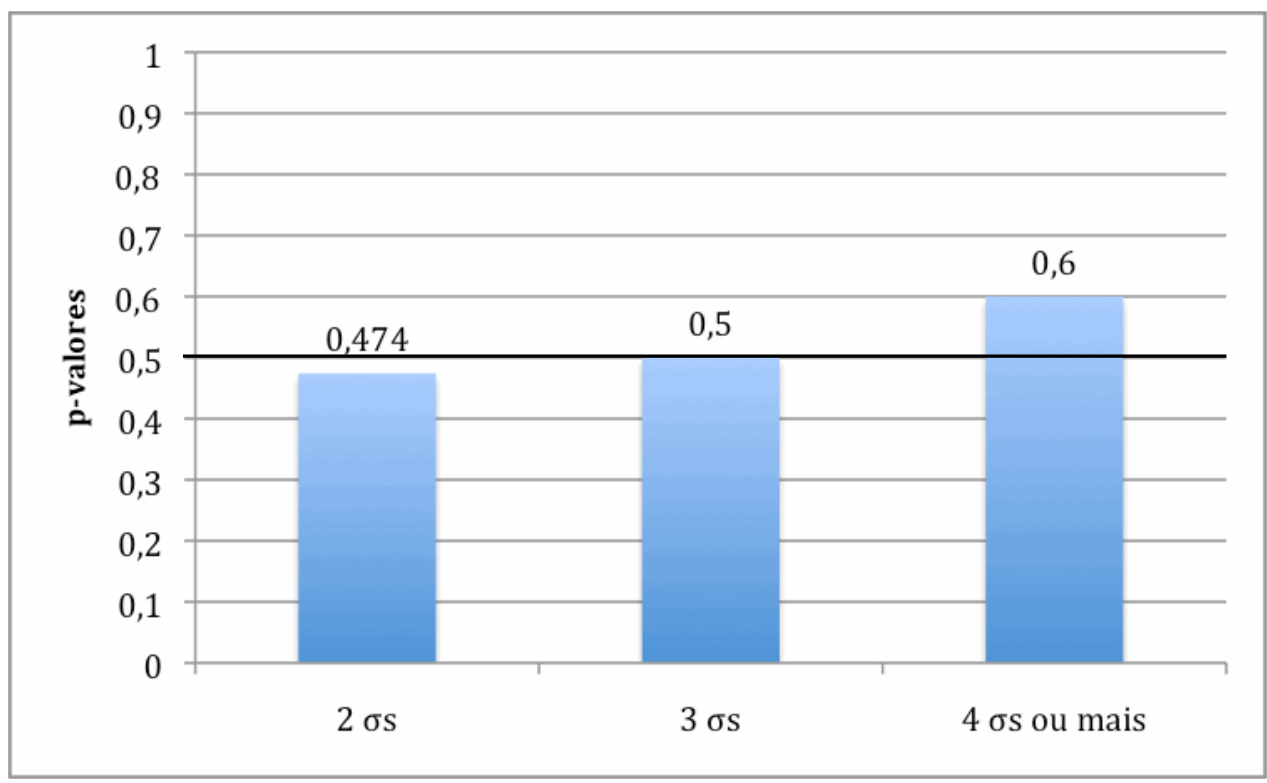

Gráfico 29- Variável Número de Sílabas na rodada 2 (Campinas)

Para esta variável Número de Sílabas, observamos que quanto maior é a palavra sujeita à queda, a tendência ao processo vai levemente aumentando. 


\subsubsection{Frequência de Uso de Palavras}

Os campineiros são sensíveis à frequência de palavra (já que a variável foi selecionada), como observamos nos resultados apresentados na tabela a seguir:

Tabela 47 - Variável Frequência de Uso de Palavras (Campinas)

\begin{tabular}{|l|c|c|c|c|}
\hline \multicolumn{1}{|c|}{ Frequência de Uso das Palavras } & N & N total & $\%$ apl & P.R. \\
\hline mais de 20.900 ocorrências no ASPA (alta) & 385 & 1570 & 24,5 & 0,502 \\
\hline de 10.451 a 20.899 ocorrências no ASPA (média) & 164 & 519 & 31,6 & 0,559 \\
\hline menos de 10.450 ocorrências no ASPA (baixa) & 182 & 909 & 20 & 0,463 \\
\hline total & 731 & 2998 & 24,4 & \\
\hline
\end{tabular}

input $=0.183 ;$ significância: 0.007

Os números da tabela acima mostram que palavras de baixa frequência de uso desfavorecem um pouco a queda de sílaba, com $p=0,46$; se a primeira palavra do contexto tiver uma frequência média, há um leve favorecimento do processo, com $p=0,559$; por fim, palavras sujeitas ao processo de alta frequência são neutras $(p=0,502)$.

No gráfico que segue, estão os pesos relativos da variável Frequência de Uso de Palavras:

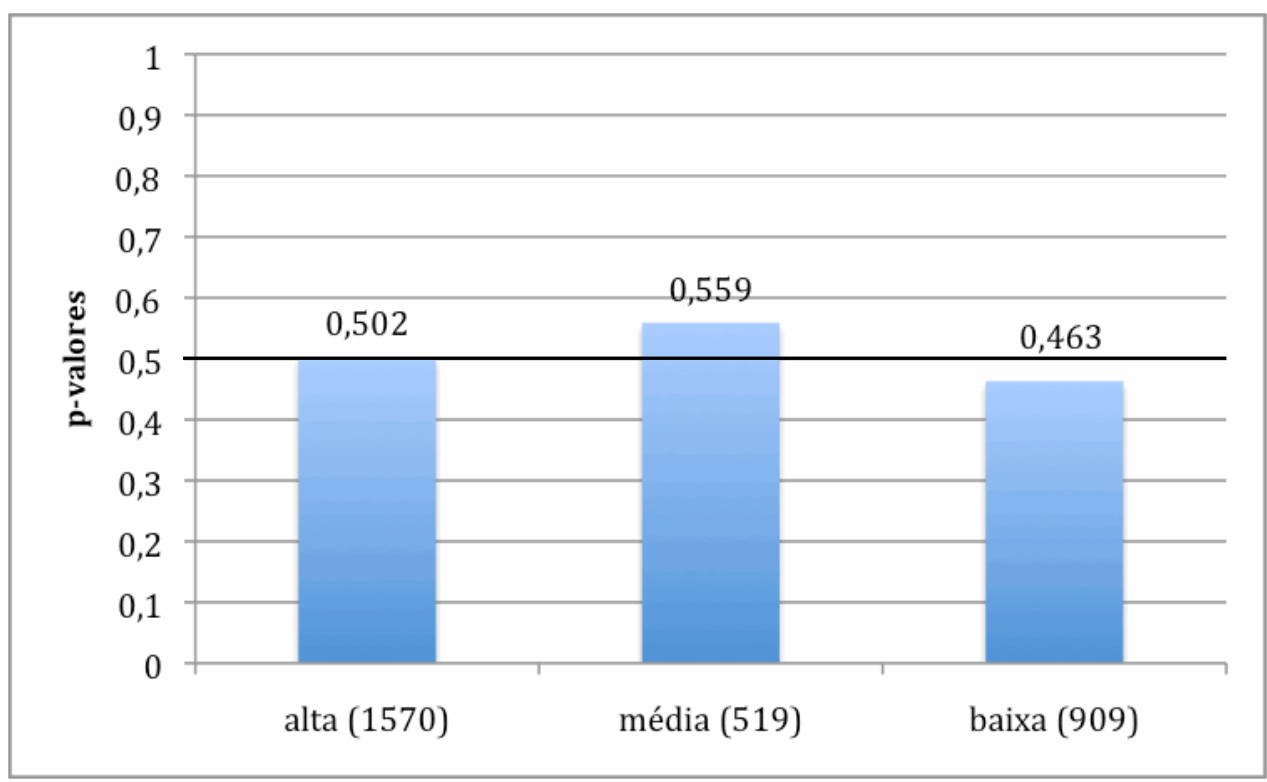

Gráfico 30- Variável Frequência de Uso de Palavras (Campinas) 
Em resumo, vimos que palavras de alta frequência parecem ser neutras na queda de sílaba; palavras de frequência média favorecem (levemente) o processo, enquanto que palavras de baixa frequência de uso o inibem um pouco.

\subsection{As variáveis sociais em Campinas}

Da mesma forma que na rodada geral e em Capivari, apenas Informantes foi a variável externa selecionada em Campineiras (cf. resultados desta variável em 5.3.2.4). Nas subseções que seguem, apresentamos as frequências encontradas para estas variáveis: Escolaridade (ver 7.2.1), Gênero (cf. 7.2.2) e Faixa Etária (em 7.2.3).

\subsubsection{Escolaridade}

As frequências obtidas com a variável Escolaridade em Campinas foram os seguintes:

Tabela 48 - Frequências da variável Escolaridade (Campinas)

\begin{tabular}{|c|c|c|c|}
\hline Escolaridade & $\mathrm{N}$ & $\mathrm{N}$ total & \%apl \\
\hline até fundamental & 501 & 1592 & 31,5 \\
\hline ensino superior & 236 & 1437 & 16,4 \\
\hline total & 737 & 3029 & \\
\hline
\end{tabular}

Como vemos na Tabela 48, os anos de estudo dos informantes são muito importantes para a regra de queda de sílaba em Campinas: as pessoas que estudaram até o ensino fundamental tiveram uma taxa de aplicação de $31,5 \%$, enquanto que, para os que fizeram faculdade, a taxa cai para $16,4 \%$.

\subsubsection{Gênero}

Apresento abaixo as taxas de queda de sílaba para os campineiros e campineiras: 
Tabela 49 - Frequências da variável Gênero (Campinas)

\begin{tabular}{|c|c|c|c|}
\hline Gênero & $\mathrm{N}$ & $\mathrm{N}$ total & $\%$ apl \\
\hline masculino & 463 & 1528 & 30,3 \\
\hline feminino & 274 & 1501 & 18,3 \\
\hline total & 737 & 3029 & \\
\hline
\end{tabular}

Como vemos na tabela, há uma diferença na porcentagem de aplicação da queda de sílaba entre homens e mulheres de Campinas (30,3\% e 18,3\%, respectivamente), e este resultado pode ser considerado confiável, já que há uma boa distribuição de ocorrências: 1528 para o gênero masculino e 1501 para o feminino.

\subsubsection{Faixa Etária}

Apresento abaixo os tokens relacionados à Faixa Etária dos informantes:

Tabela 50 - Frequências da variável Faixa Etária (Campinas)

\begin{tabular}{|c|c|c|c|}
\hline Faixa Etária & $\mathrm{N}$ & $\mathrm{N}$ total & \%apl \\
\hline de 20 a 35 & 376 & 1491 & 25,2 \\
\hline mais de 50 & 361 & 1538 & 23,5 \\
\hline total & 737 & 3029 & \\
\hline
\end{tabular}

Como observamos na Tabela 50 , pessoas na faixa de 20 a 35 anos de idade e aqueles que têm mais de 50 anos têm uma taxa de aplicação de queda de sílaba muito semelhante.

\subsubsection{Informantes}

Os pesos relativos obtidos para os campineiros foram: 


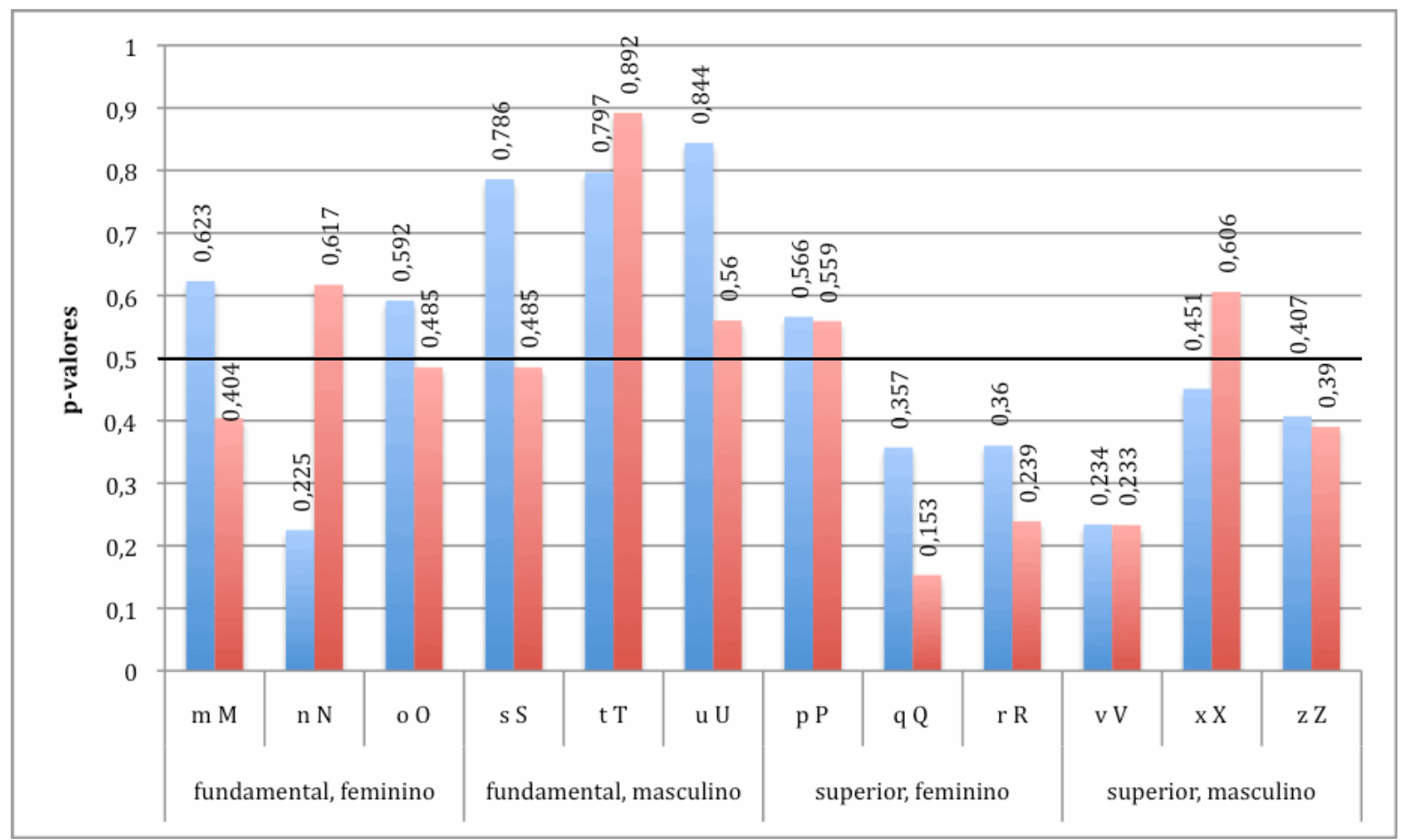

Gráfico 31 - Pesos relativos da variável Informante (Campinas)

Para Campinas, resultados de favorecimento de queda de sílaba foram encontrados em 11 fatores e apenas 3 deles são informantes que têm ensino superior. Os informantes neutros à queda de sílaba são 3 : $O$, com $p=0,485$; $S$ com $p=0,485$; e $x$, com um resultado $p=0,451$. Os 10 informantes restantes desfavorecem a queda de sílaba e apenas duas mulheres têm ensino fundamental $(M, \operatorname{com} p=0,404$; e $n$, com $p=0,225)$. 


\section{CAPÍTULO VIII}

\section{Comparação das duas cidades}

Como vimos na subseção 1.2, a principal questão a ser respondida nesta tese é identificar se a queda de sílaba tem restrições diferentes em Capivari e em Campinas. Assim, neste capítulo, comparamos os resultados das duas cidades, de modo a verificar se a queda de sílaba tem as mesmas características nas duas cidades, ou se as cidades têm regras diferentes para a aplicação do processo.

Para que a comparação fosse feita de forma objetiva, seguimos os seguintes critérios para definir se houve um resultado diferente, semelhante ou igual para os fatores das duas cidades:

- Iguais: são fatores que têm a mesma tendência nas duas cidades, e a diferença entre os pesos relativos são pequenas - isto é, há uma mesma tendência e produtividade da regra;

- Semelhantes: dentro de uma mesma variável, há um fator(s) com comportamento(s) idêntico(s) nas duas cidades, mas a produtividade é diferente, ou seja, pode ser que um fator seja aplicado mais vezes numa cidade do que na outra; e

- Diferentes: são os fatores com tendências diferentes nas duas cidades (por exemplo, favorecimento versus desfavorecimento, desfavorecimento versus neutralidade, favorecimento versus neutralidade, etc.) e, consequentemente, a produtividade também é diferente; adicionalmente, consideramos diferentes as variáveis que foram selecionadas numa cidade e não em outra, dado que, se uma variável é selecionada, podemos interpretar que aquela variável condiciona o processo e, de modo contrário, uma variável não selecionada indica que um conjunto de fatores não exerce qualquer efeito no processo.

Este capítulo está organizado da seguinte maneira: em 8.1, apresento as características iguais entre as duas cidades; em 8.2, estão as similaridades; em 8.3, 
apresento as diferenças; na subseção 8.4 , está o resumo das comparações; e em 8.5, há uma conclusão do capítulo - de que há duas regras de queda de sílaba para Capivari e Campinas.

\subsection{As igualdades}

Nesta subseção, apresentamos os resultados que foram iguais nas duas cidades, quais sejam: a Cavidade Oral das Consoantes (cf. subseção 8.1.1); a Prosódia (ver 8.1.2); e os grupo de fatores externos (cf. 8.1.3).

\subsubsection{Cavidade Oral das Consoantes}

A primeira característica de queda de sílaba que é a mesma em Capivari e Campinas está relacionada às consoantes, segmentos analisados em duas variáveis: numa primeira variável, separamos todas as consoantes com relação aos traços da cavidade oral (ponto de C e [contínuo]); e, numa outra variável, além de investigar as cavidades orais das consoantes, examinamos também o traço [nasal], separando num fator todos os contextos que tivessem uma ou duas nasais. As hipóteses para estas duas variáveis foram que haveria uma maior tendência ao processo com coronais, com base na subespecificação destes segmentos; e a outra hipótese foi que não haveria bloqueio com outras consoantes. Não levantamos nenhuma hipótese específica para as nasais, mas o propósito foi ver como estes segmentos podem atuar no processo, bem como examinar qual das duas configurações é mais adequada para descrever as consoantes relacionadas à queda de sílaba: separar ou não as nasais.

Com a primeira configuração (sem distinção de [nasal]), a variável Cavidade Oral das Consoantes não foi selecionada em nenhuma das rodadas - ou seja, foi um resultado igual nas duas cidades.

\subsubsection{Prosódia}

Outra variável que revelou resultados iguais nas duas cidades foi Prosódia. As hipóteses formuladas foram que não há um nível que bloqueie o processo e que o nível com uma maior tendência ao apagamento é o de frase fonológica (Battisti 2004, Pavezi 
2006a e Leal 2006).

Observe no Gráfico 32 abaixo que os pesos relativos para as duas cidades são muito próximos: ${ }^{102}$

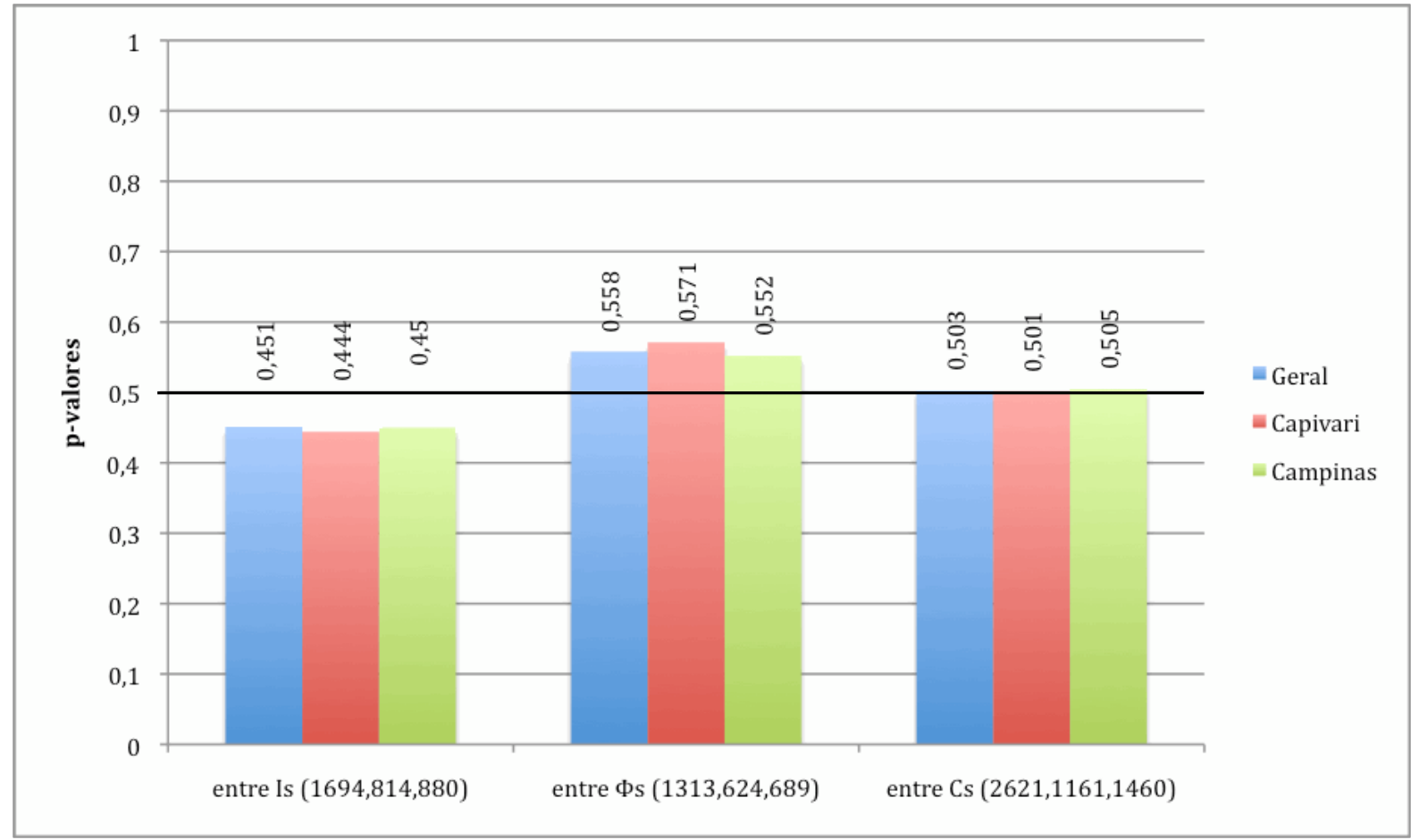

Gráfico 32- Comparação da variável Prosódia na rodada Geral, em Capivari e em Campinas

Os resultados de Prosódia foram praticamente iguais nas rodadas Geral, de Capivari e de Campinas e, em todas elas, o resultado foi robusto, com uma boa distribuição dos dados. Em ambas as cidades, entre sentenças, há um leve desfavorecimento da queda de sílaba (fronteira entre frase entonacional); há um leve favorecimento do processo entre frases fonológicas, o que corrobora a hipótese inicial; e se a primeira e a segunda sílabas do contexto segmental estiverem entre dois grupos clíticos, há uma neutralidade.

Assim, concluímos que o efeito da hierarquia prosódica na queda de sílaba em Capivari e em Campinas é idêntica.

102 Os números entre parênteses nos gráficos deste capítulo representam os números de tokens das variantes, na seguinte ordem: da rodada Geral, da rodada de Capivari e na rodada de Campinas. Por exemplo, no Gráfico 32, os números entre parênteses na variante entre Is indicam que houve 1694 dados na rodada Geral, 814 dados em Capivari e 880 tokens em Campinas. 


\subsubsection{Os grupos de fatores externos}

Outra igualdade entre as duas cidades que pôde ser verificada está nas variáveis externas: em nenhuma das rodadas (incluindo a rodada Geral) as variáveis externas Escolaridade, Gênero e Faixa Etária foram selecionadas e, de modo oposto, a variável Informantes foi selecionada em todas elas.

\subsection{As similaridades}

Nesta subseção, apresento os resultados que podem ser considerados similares entre as duas cidades: houve quatro variáveis linguísticas com tendências iguais, mas há algumas diferenças entre os pesos relativos que podem indicar particularidades em cada cidade. A comparação da variável de Cavidade Oral das Consoantes com Distinção de [nasal] está apresentada na subseção 8.2.1; a Cavidade Oral das Vogais está em 8.2.2; a Estrutura Silábica está apresentada em 8.2.3; na subseção 8.2.4, está a Métrica; finalmente, na subseção 8.2.5 está a variável Gênero.

\subsubsection{Cavidade Oral das Consoantes com Distinção de [nasal]}

Como vimos em 8.1, as hipóteses levantadas para as consoantes foram que coronais têm uma tendência ao processo, e não há bloqueio nos outros contextos.

Observe o gráfico abaixo dos pesos relativos nas três rodadas Geral, de Capivari e de Campinas: 


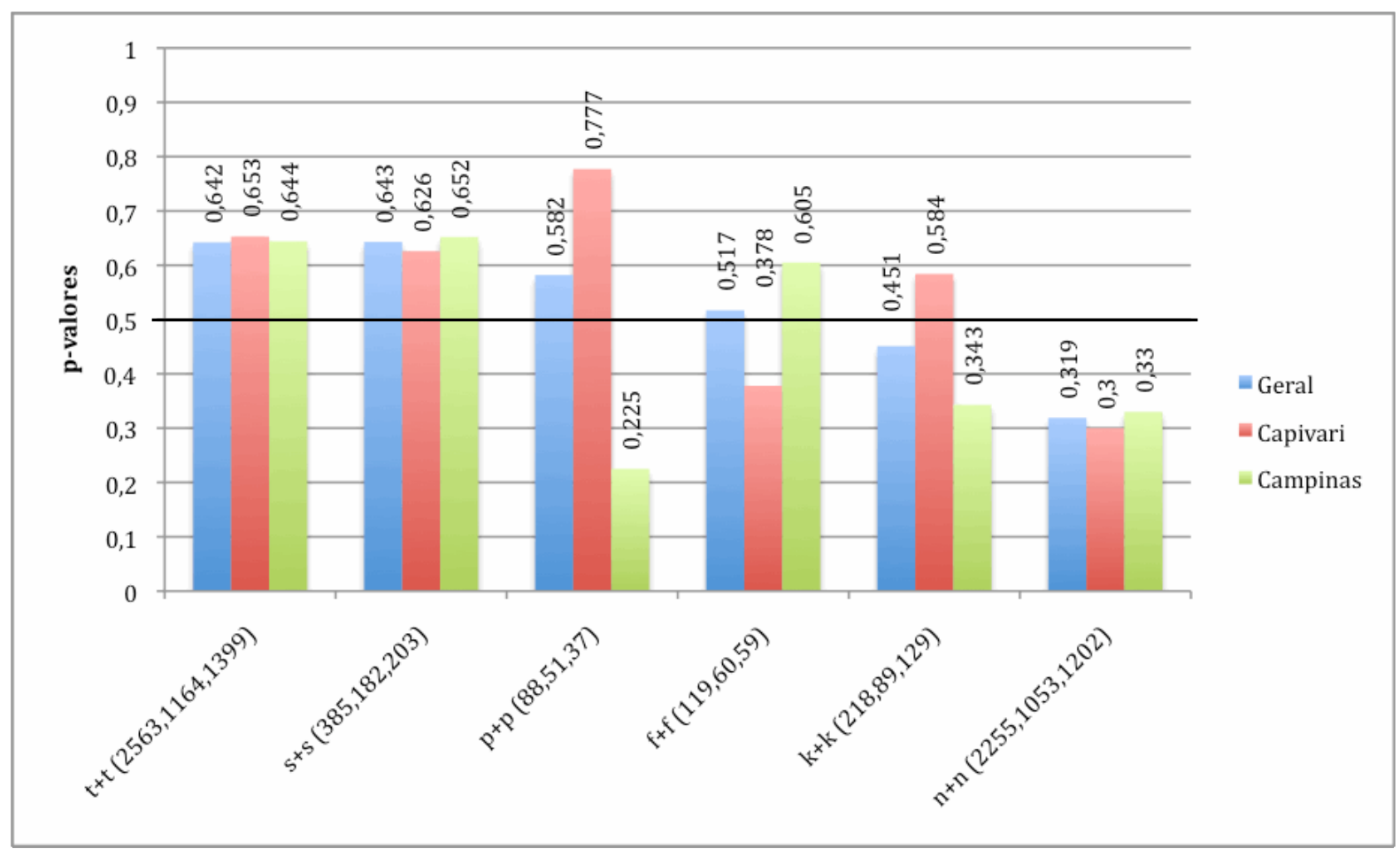

Gráfico 33- Comparação da variável Cavidade Oral das Consoantes com Distinção do Traço [nasal] na rodada Geral, em Capivari e em Campinas

As variáveis de consoantes coronais (orais) têm comportamento igual nas duas cidades (com pesos relativos muito próximos), favorecendo a queda de sílaba, o que corrobora a hipótese inicial de subespecificação das coronais; quanto às nasais, há um desfavorecimento do processo, também de forma igual nas duas cidades. Assim, estes resultados apontam que, para nasais e coronais orais, as duas cidades têm preferências (quase que) idênticas: coronais favorecem e nasais inibem.

Interessantemente, a Cavidade Oral das Consoantes separando o traço [nasal] num fator, foi selecionada nos dois dialetos (cf. também resultados das consoantes com distinção de nasalidade na rodada geral 5.3.1.1.2; subseção 6.1.1.2 para a rodada de Capivari; e 7.1.1.2 para Campinas), um resultado que pode ser considerado idêntico nas duas cidades, pois significa que Cavidade Oral das Consoantes com Distinção de [nasal] interfere na aplicação de queda de sílaba nos dois dialetos, diferentemente de Cavidade Oral das Consoantes (sem separar [nasal]). No entanto, não podemos considerar que esta variável atua na queda de sílaba de modo idêntico nos dois dialetos porque as dorsais interferem no processo de modo oposto: Capivari favorece o processo neste contexto, 
enquanto que Campinas desfavorece.

Das labiais, não podemos tirar conclusões, na medida em que não houve uma quantidade confiável de dados nas três rodadas (rodada Geral, rodada de Capivari e rodada de Campinas).

Assim, consideramos que Cavidade Oral das Consoantes com Distinção de [nasal] tem uma atuação semelhante nas duas cidades: por um lado, os resultados das coronais orais (independentemente de [contínuo]) e das nasais foram muito parecidos nas duas cidades; por outro lado, o traço [dorsal] tem um comportamento oposto - há um favorecimento da regra em Capivari e um desfavorecimento em Campinas.

\subsubsection{Cavidade Oral das Vogais}

Para esta variável, a hipótese foi que pode haver uma possibilidade de aplicação de queda de sílaba com dorsais (com base em Pavezi 2006a e Leal 2006, para quem é possível apagamentos com vogais diferentes de [+alto], na terminologia das autoras), e não somente com coronais e dorso-labiais (como apontam Alkmim \& Gomes 1982). Esta variável foi selecionada nas duas cidades e apresento os pesos relativos no gráfico a seguir: 


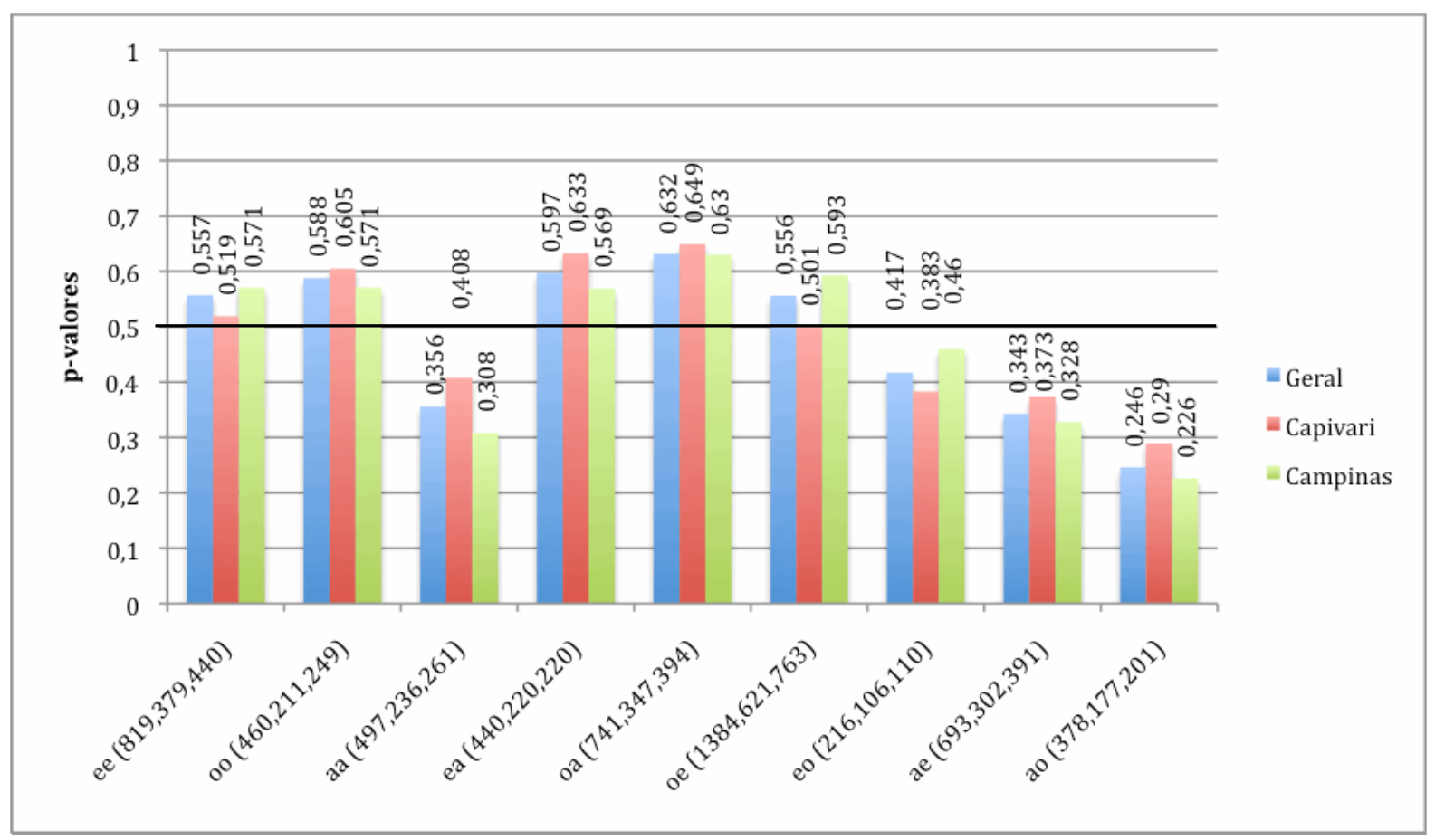

Gráfico 34- Comparação da variável Cavidade Oral das Vogais na rodada Geral, em Capivari e em Campinas

Observamos primeiramente as diferenças entre as duas cidades: nas sequências com duas coronais (ver ee no Gráfico 34) e com uma dorso-labial seguida de um coronal (cf. oe), as tendências são diferentes: estes contextos favorecem a queda de sílaba em Campinas, e são neutros em Capivari.

Podemos considerar semelhantes quatro contextos: uma coronal seguida de uma dorsal (sequência ea), em que há uma tendência à queda de sílaba nos dois dialetos, e o favorecimento é maior em Capivari; os outros três contextos dizem respeito a sequências com uma dorsal na primeira posição, em que o processo é desfavorecido nas duas cidades, mas podemos notar que os apagamentos de dorsais na primeira sílaba são mais aceitos em Capivari do que em Campinas. Interessantemente, como vimos na subseção anterior (cf. 8.2.1), contextos com o ponto de $\mathrm{C}$ [dorsal] também diferem nos dois dialetos no que concerne a consoantes: há um favorecimento do processo em Capivari e o apagamento é desfavorecido em Capivari. Em outras palavras, o ponto de $C$ [dorsal] das consoantes e das vogais interfere na queda de sílaba de formas semelhantes nas duas cidades (há uma aceitabilidade maior de apagamento com estes segmentos em Capivari do que em 
Campinas).

Uma outra semelhança entre as cidades está nos contextos com duas vogais iguais (cf. contextos ee com duas coronais, oo com duas dorso-labiais e aa com duas dorsais), de onde podemos concluir que a igualdade das vogais não é uma característica importante para a queda de sílaba: os pontos de C [coronal] ou [dorso-labial] favorecem o processo, enquanto que a igualdade nos contextos com duas [dorsal] resulta em desfavorecimento da queda de sílaba em ambos os dialetos.

Do contexto de uma coronal seguida de uma dorso-labial (cf. eo), nada podemos concluir, em consequência do baixo número de tokens nestes fatores para as duas cidades.

Os resultados desta variável corroboram a hipótese inicial, pois houve aplicação de queda de sílaba, além de coronais e de dorso-labiais, também com dorsais (cf. Pavezi 2006a e Leal 2006); e, ao contrário de Alkmim \& Gomes (1982), contextos com vogais dorsais não bloqueiam o processo - estes contextos desfavorecem o processo.

Concluímos que a variável Cavidade Oral das Vogais atua na queda de sílaba de modo similar nas duas cidades: são diferentes nos fatores ee e oe (são contextos neutros

em Capivari e favorecedores em Campinas); semelhantes em contextos ea (há favorecimento nas duas cidades, sendo um pouco maior em Capivari) e em contextos com dorsais (desfavorecem, com uma aceitação maior entre os capivarianos do que entre os campineiros); e sequências oo e oa são iguais nas duas cidades (há favorecimento do processo, com pesos relativos próximos).

\subsubsection{Estrutura Silábica}

A hipótese levantada para esta variável foi que a aplicação do processo depende de a sílaba ser leve ou pesada: sílabas simples tenderiam à aplicação do processo, enquanto que sílabas pesadas o inibiriam. No gráfico abaixo estão os pesos relativos obtidos nas três rodadas: 


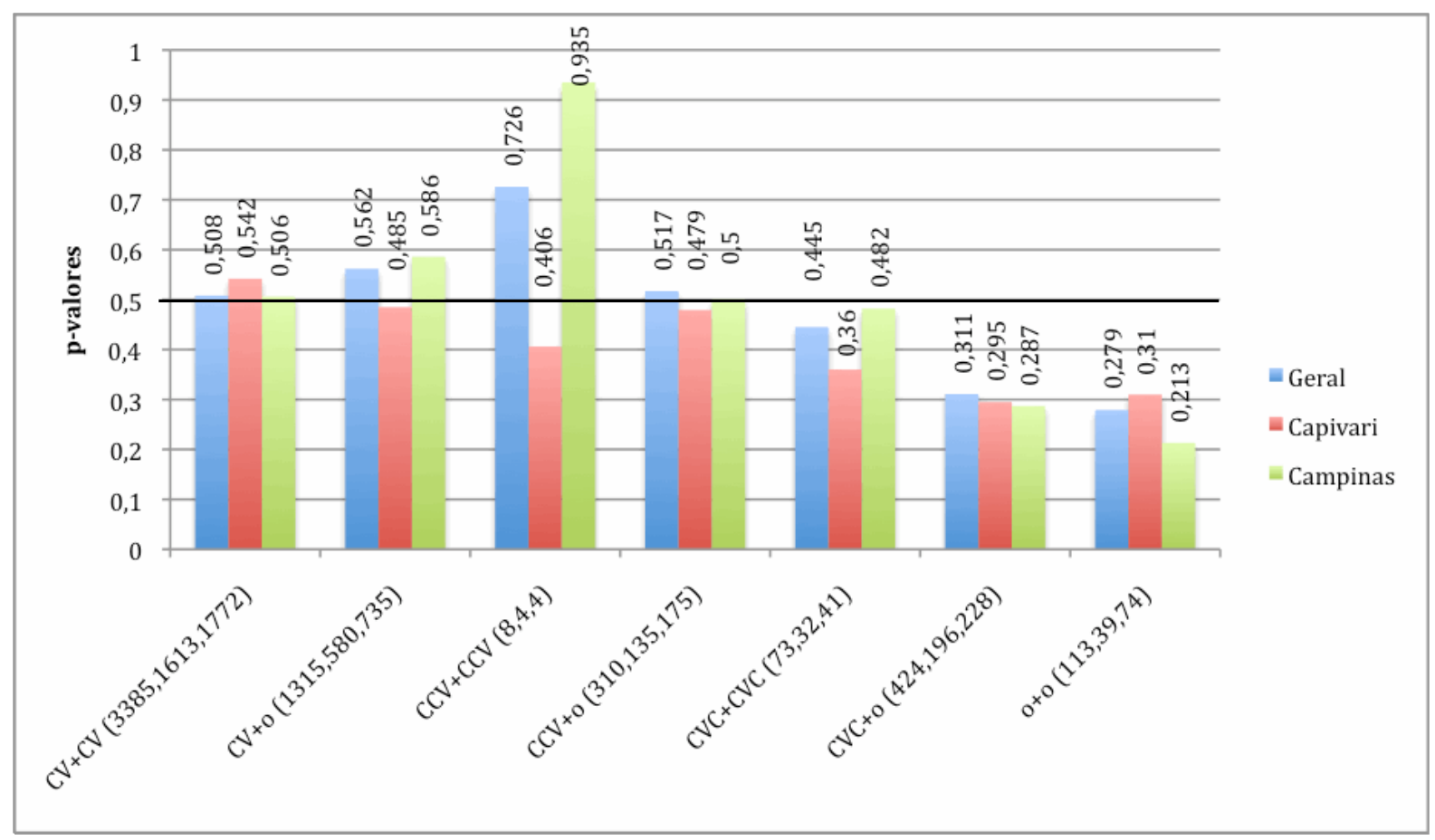

Gráfico 35- Comparação da variável Estrutura Silábica na rodada Geral, em Capivari e em Campinas

Com relação às diferenças entre as cidades, contextos com duas sílabas simples (cf. $\mathrm{CV}+\mathrm{CV}$ ) favorecem (levemente) o processo em Capivari e são neutros em Campinas; para sequências em que há uma sílaba simples seguida de outros tipos de estruturas, isto é, estruturas diferentes de CV (ver CV+o no gráfico), ocorre o contrário: há um (leve) favorecimento em Campinas e neutralidade em Capivari.

Em um contexto com uma sílaba de ataque ramificado seguida de outros tipos de estruturas (que não sejam CCV - cf. CCV+o no gráfico), há uma neutralidade nas duas cidades; em sequências de sílabas sujeitas à queda que tenham coda ramificada e seguidas de outros tipos de estruturas, que sejam diferentes de CVC (ver CVC+o no gráfico) os pesos relativos são muito parecidos, indicando um desfavorecimento do processo. Assim, podemos interpretar que, estes dois contextos ( $C C V+o$ e $C V C+o)$ são iguais nas duas cidades.

Com relação às sequências em que há ataque ramificado em ambas as sílabas (cf. contexto $\mathrm{CCV}+\mathrm{CCV}$ ) e também estruturas com coda nas duas sílabas (ver CVC+CVC), os resultados são inconclusivos, já que o número de tokens foi baixo (a maior quantidade 
nestes casos foi 73 dados).

A hipótese inicial foi parcialmente confirmada para sílabas com coda: de fato, estas estruturas desfavorecem o processo em ambos os dialetos; mas somente se estiver na primeira posição, sem necessidade de o contexto ter as duas sílabas com estrutura CVC para contextos CVC + CVC, o número de tokens foi muito baixo. Outra hipótese para esta variável era que quanto mais leve fosse a sílaba sujeita ao apagamento, maior seria a tendência à queda; entretanto, e sílabas leves (também na primeira posição) ou favorecem somente em Capivari, e em Campinas são neutras ao processo. Finalmente, sílabas com ataque ramificado (em primeira posição) são neutras - não tínhamos uma hipótese, mas levantamos a seguinte pergunta (cf. subseção 4.1.4.1.2): a segunda consoante do ataque "atrapalha" a queda de sílaba ou é inerte? Pudemos verificar que o comportamento de estruturas CCV é semelhante a CV, isto é, estruturas CCV são neutras ao processo - a segunda consoante do ataque não "atrapalha" a queda de sílaba.

\subsubsection{Métrica}

A hipótese para a variável Métrica foi que aplicar (ou não) a queda de sílaba decorre de uma otimização rítmica, com base no PAR: se houver um resultado (da aplicação do processo) em que os acentos se alternem em fortes e fracos, o apagamento será implementado; por outro lado, se uma sequência rítmica resultar em choque acentual, a queda de sílaba será inibida.

No gráfico a seguir, apresento os pesos relativos dessa variável: 


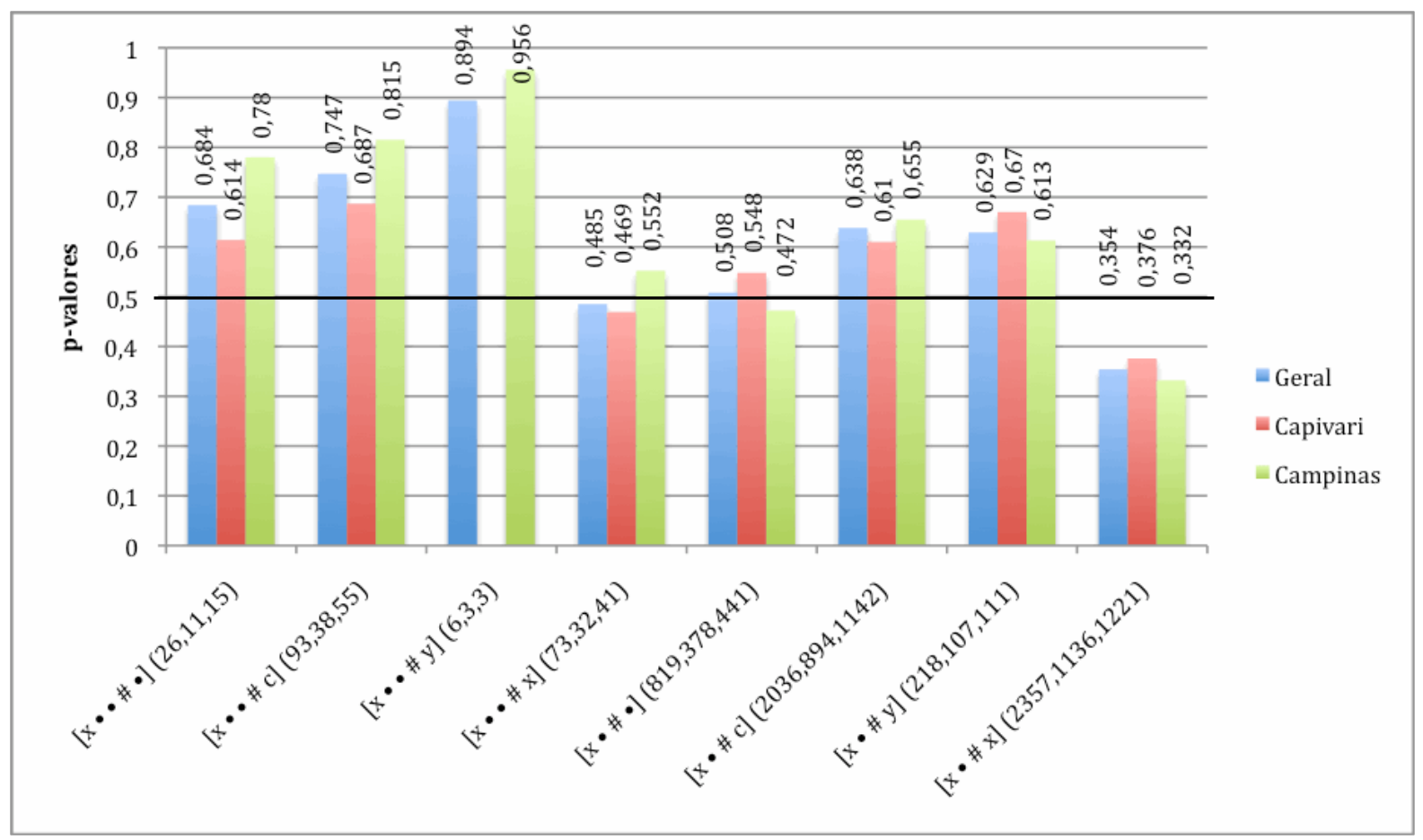

Gráfico 36- Comparação da variável Métrica na rodada Geral, em Capivari e em Campinas

Podemos observar no Gráfico 36 (cf. números entre parênteses) que houve baixas ocorrências para as quatro sequências em que a primeira palavra é um dátilo [ $x \cdot \cdots$ ]. Note que não há um peso relativo para o fator com uma sílaba forte seguida de duas fracas e outra sílaba de acento secundário $[\mathrm{x} \cdots \#$ y] em Capivari, já que esta sequência resultou em knockout $(\mathrm{N}=0 / 3)$.

Para os quatro contextos com número de tokens consistente (aqueles em que primeira palavra tem uma estrutura $[\mathrm{x} \cdot])$, os resultados foram semelhantes nas duas cidades: contextos $[\mathrm{x} \cdot \# \mathrm{c}]$ e $[\mathrm{x} \cdot \# \mathrm{y}]$ favorecem a queda de sílaba, e sequências originais $[\mathrm{x} \cdot \# \mathrm{x}$ ] desfavorecem o processo. Neste caso, uma vez aplicada a queda de sílaba, o resultado é uma sequência rítmica [ $\mathrm{x} \# \mathrm{x}$ ], em que há duas sílabas fortes adjacentes, o que confirma a hipótese inicial: uma sequência rítmica ruim (de acordo com o PAR) desfavorece o processo. Mas consideramos que a variável atua de forma semelhante porque contextos $[\mathrm{x} \cdot \# \cdot]$ são favorecedores em Capivari e neutros em Campinas. 


\subsubsection{Gênero}

Dos resultados da análise das frequências das variáveis externas, a única variável com resultados semelhantes nas duas cidades foi Gênero: os homens aplicam mais do que as mulheres. No gráfico a seguir, apresento as frequências desta variável nas três rodadas:

Tabela 51 - Comparação da variável Gênero na rodada Geral, em Capivari e em Campinas

\begin{tabular}{|c|c|c|c|}
\hline Gênero & $\%$ Geral & $\%$ Capivari & $\%$ Campinas \\
\hline masculino & 26,3 & 21,6 & 30,3 \\
\hline feminino & 15,8 & 13 & 18,3 \\
\hline
\end{tabular}

Apesar de as taxas de aplicação serem diferentes nas duas cidades (e, vale lembrar, os números de tokens também são diferentes - Capivari com 2599 dados e Campinas com 3029), é interessante notar que a diferença nas porcentagens entre os fatores masculino e feminino foi muito semelhante: os capivarianos aplicam 1,662 vezes mais do que as capivarianas; e os campineiros aplicam 1,656 mais vezes do que as campineiras.

Com base no resultado de que a variável Gênero não foi selecionada, interpretamos que não importa, para a aplicação da regra de queda de sílaba, se o falante é homem ou mulher, seja em Capivari ou em Campinas. Interessantemente, a diferença entre as aplicações, por um lado, de capivarianos e capivarianas, e por outro, de campineiros e campineiras foi muito semelhante (por volta de $1,66 \%$ ).

\subsection{As diferenças}

Consideramos três variáveis linguísticas com resultados inteiramente diferentes nos dois dialetos, já que foram selecionadas em apenas uma das cidades: Igualdade de Segmentos, selecionada apenas em Campinas (cf. 8.3.1); Número de Sílabas, somente em Capivari (ver 8.3.2); e Frequência de uso, unicamente em Campinas (cf. 8.3.3). Para as variáveis externas, os resultados diferentes nas duas cidades foram Escolaridade e Faixa Etária (cf. subseção 8.3.4). 


\subsubsection{Igualdade de Segmentos}

$\mathrm{Na}$ variável Igualdade de Segmentos, a hipótese foi que haveria uma maior aplicação de queda de sílaba se seu conteúdo fosse idêntico ou semelhante (neste caso, a diferença vai além do traço [vozeamento], incluindo [nasal] e [anterior, distribuído]). Assim, a expectativa seria de que contextos com duas sílabas segmentalmente iguais favoreceriam o processo; e, de modo inverso, sílabas com segmentos diferentes desfavoreceriam o processo. Esta variável só foi selecionada em Campinas, o que significa que a igualdade de segmentos nas sílabas não é importante para Capivari. Na subseção 6.1.1.1, foram apresentados os pesos relativos da rodada 2 em Capivari, já que a rodada 1 não foi selecionada nesta cidade (cf. resumo da descrição das rodadas em (234), na subseção 5.2.).

Apresento a seguir os pesos relativos obtidos nas duas cidades: ${ }^{103}$

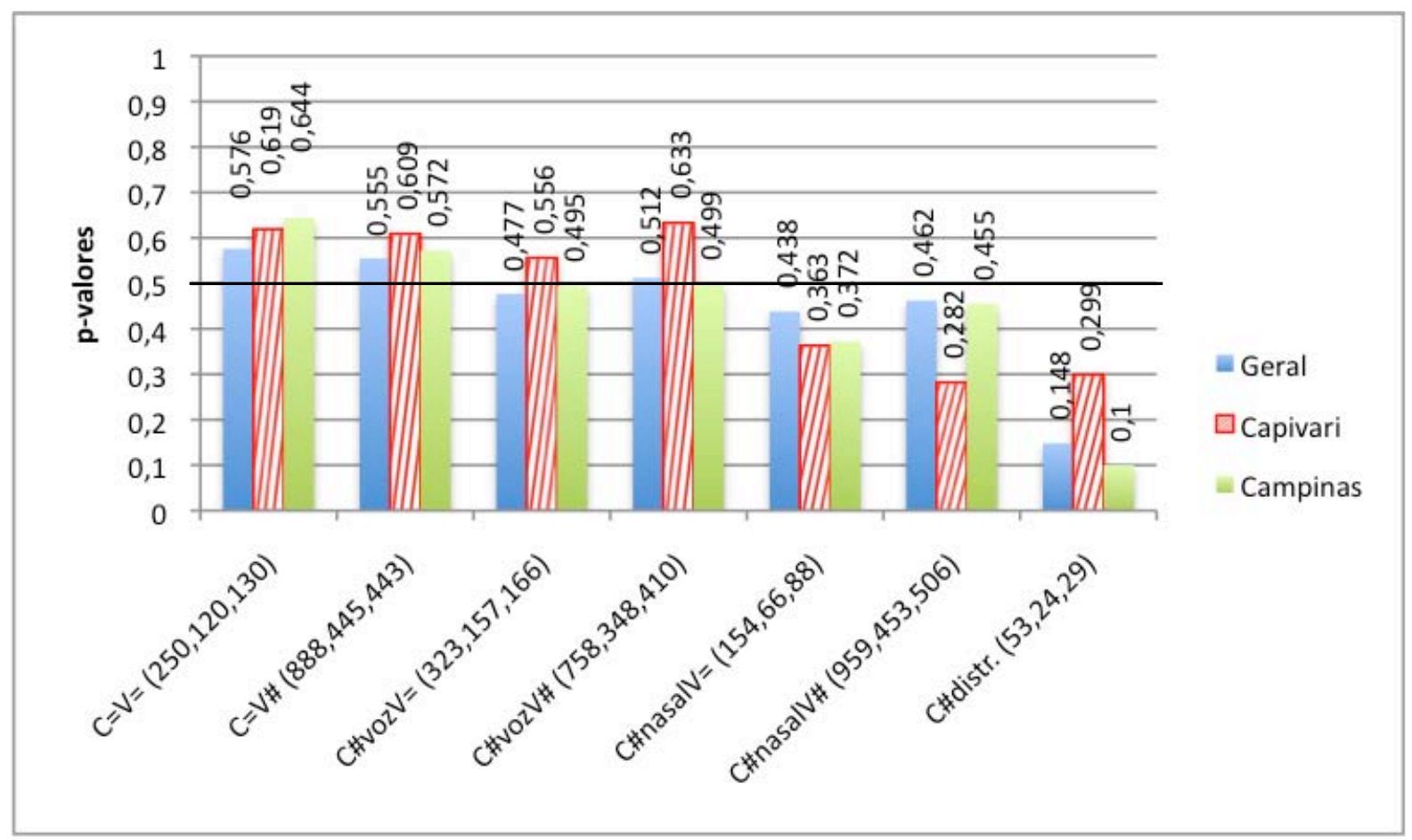

Gráfico 37-Comparação da variável Igualdade de Segmentos na rodada Geral, em Capivari e em Campinas

103 No Gráfico 37, os resultados de Capivari aparecem com preenchimentos diferentes para indicar que a variável não foi selecionada na rodada 1, mas sim na rodada 2 (cf. resumo das rodadas em (234), em 5.2). 
Dos resultados para Igualdade de Segmentos, tratamos primeiramente dos fatores iguais nas duas cidades. Vimos que o processo é favorecido no fator de sílabas idênticas, confirmando a hipótese inicial, e também no contextos em que as consoantes são iguais com vogais diferentes, em ambas as cidades. Se o contexto consonantal for diferente em [nasalidade] (com vogais iguais ou diferentes entre si), o processo é inibido em Capivari e em Campinas. Quanto às vogais, estes segmentos parecem ser inertes ao processo, já que, sendo as vogais iguais ou diferentes, não há mudança na tendência em que as consoantes são iguais (cf. $\mathrm{C}=\mathrm{V}=$ versus $\mathrm{C}=\mathrm{V \#}$ ); a tendência é a mesma (em Capivari, favorecendo o processo e, em Campinas, há uma neutralidade) nos fatores em que as consoantes têm valores diferentes para [vozeamento] e as vogais forem iguais versus

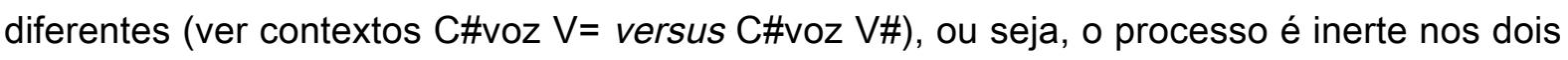
contextos em Campinas e favorecido em Capivari; por fim, podemos nos certificar da neutralidade das vogais também nos ambientes em que as consoantes são diferentes no traço [nasal] (cf. C\#nasal $\mathrm{V}=$ versus C\#nasal $\mathrm{V \# ):} \mathrm{em} \mathrm{ambos} \mathrm{os} \mathrm{casos,} \mathrm{há} \mathrm{inibição} \mathrm{do}$ processo.

Notamos que há uma diferença entre as cidades: se as consoantes forem diferentes em [vozeamento] (com vogais iguais ou diferentes), o processo é favorecido em Capivari e neutro em Campinas.

Finalmente, no que concerne às diferenças consonantais nos traços [anterior, distribuído], nada podemos concluir, uma vez que o número de tokens deste fator nas duas rodadas foi muito baixo.

Mesmo com poucas diferenças entre as cidades, chamamos a atenção que esta variável de Igualdade de Segmentos só foi selecionada em Campinas, e concluímos que ter sílabas segmentalmente iguais ou diferentes não é relevante para a aplicação do processo em Capivari. Assim, a variável Igualdade de Segmentos tem efeitos diferentes nas duas cidades.

\subsubsection{Número de Sílabas}

Com relação ao Número de Sílabas, esta variável não foi selecionada em Campinas, ou seja, a variável não é importante na implementação da regra nesta cidade; ainda, 
podemos interpretar que o efeito do tamanho da palavra é diferente nas duas cidades (importa para Capivari e não importa para Campinas). A hipótese era que quanto maior fosse a palavra, maior seria a tendência à queda. Dos resultados para Capivari, pudemos observar que dissílabos desfavorecem o processo, trissílabos parecem ser inertes e palavras que tenham 4 sílabas ou mais favorecem a queda de sílaba. Assim, concluímos que o favorecimento de queda de sílaba aumenta à medida que a palavra se torna mais extensa (o que corrobora os resultados de Tenani (2002): a haplologia é mais aplicada em enunciados de tamanhos maiores).

\subsubsection{Frequência de Uso de Palavras}

A última variável linguística que apresentou diferenças entre Capivari e Campinas é Frequência de Uso de Palavras, já que esta variável não foi selecionada na rodada de Capivari - isto é, os capivarianos não levam em conta se a palavra é frequente ou rara. Então, mais uma vez, há diferença nesta variável entre os campineiros e os capivarianos.

A hipótese foi que quanto mais frequente fosse a palavra, maior seria a tendência ao apagamento. Os resultados de Campinas apontam que se a palavra sujeita ao apagamento tiver uma frequência alta de uso o processo é inerte e que palavras de frequência média de uso favorecem a aplicação. Para palavras de baixa frequência de uso, há um desfavorecimento do processo, e este é o único fator que corrobora a hipótese inicial.

\subsubsection{Escolaridade e Faixa Etária}

Com relação às variáveis externas, vimos que as frequências de aplicação de queda de sílaba na rodada Geral foram diferentes nas duas cidades (cf. a variável Cidade da rodada Geral em 5.3.2.5) e, mais ainda, os resultados foram contrários à hipótese proposta no envelope de variação (em que propusemos que Capivari aplicaria mais do que Campinas, cf. subseção 4.1.4.2.5): Campinas aplicou mais, com 24,3\%, e Capivari teve uma taxa de 17,3\%. Dessa forma, apresentamos as análises feitas das variáveis externas com base nas frequências, já que não foi possível obter os pesos relativos (cf. 6.2 e 7.2 variáveis externas para Capivari e Campinas, respectivamente). Apresento abaixo as frequências das variáveis externas com resultados diferentes nas duas cidades, 
Escolaridade e Faixa Etária:

Tabela 52 - Frequências das variáveis externas de Escolaridade e Faixa Etária da rodada Geral, em Capivari e em Campinas

\begin{tabular}{|c|c|c|c|c|}
\hline variável & fator & geral & Capivari & Campinas \\
\hline \multirow{2}{*}{ escolaridade } & até fundamental & 25,3 & 17,2 & 31,5 \\
\cline { 2 - 5 } & ensino superior & 16,9 & 17,3 & 16,4 \\
\hline \multirow{2}{*}{ faixa etária } & de 20 a 35 & 22,6 & 19,7 & 25,2 \\
\cline { 2 - 5 } & mais de 50 & 19,5 & 14,6 & 23,5 \\
\hline
\end{tabular}

Ao analisar apenas a rodada geral, notamos que, para Escolaridade, o fator que indica pessoas que estudaram, no máximo, até o ensino fundamental é aquela que resultou numa maior frequência; com relação à Faixa Etária, o processo ocorre mais entre os mais jovens do que entre os mais velhos. Como foi visto em 8.1, a variável Gênero foi semelhante nas duas cidades: os homens (capivarianos e campineiros) aplicam mais do que as mulheres (capivarianas e campineiras). Em resumo, as variáveis externas da rodada Geral apontam que homens mais jovens com pouca escolaridade são os que mais favorecem a queda de sílaba. Interessantemente, mudanças linguísticas se originam com as características sociais de gênero masculino, mais jovens e com poucos anos de estudo (cf. Labov 2001: 294-322). ${ }^{104}$ Com base apenas na análise da rodada Geral, podemos ser tentados a levantar uma hipótese de que há uma mudança em curso, no entanto, essa aparente direção de mudança não se sustenta ao olharmos para as cidades separadamente: há diferenças na escolaridade, visto que pessoas que estudaram até o ensino até fundamental aplicaram mais do que aqueles que cursaram ensino superior em Campinas, enquanto que, em Capivari, praticamente não há diferenças entre os dois fatores, já que as frequências estão muito próximas. Com relação à Faixa Etária, vemos na Tabela 52 que não houve diferença na aplicação de queda de sílaba para os campineiros, enquanto que há diferenças entre os mais jovens e os mais velhos em Capivari: na Faixa Etária entre 20 e 35 anos, há uma maior aplicação do que na faixa de mais de 50 anos.

104 Dado que o objetivo desta tese foi verificar, principalmente, as interferências fonológicas que atuam na queda de sílaba (cf. seção 1.2.2), o corpus não foi constituído de modo a permitir uma análise de mudança: há uma lacuna entre as duas variantes de Faixa Etária, sendo que o primeiro intervalo vai de 20 a 35 anos, e o segundo é de falantes com mais de 50 anos. 
Concluímos que, para Escolaridade, parece haver uma diferença ente as duas cidades: em Capivari, a diferença nas porcentagens para os dois fatores é muito próxima, de $0,1 \%$ (17,2\% para os que estudaram até o ensino fundamental e $17,3 \%$ para os que cursaram ensino superior); em Campinas, as pessoas que estudaram até o ensino fundamental implementam a queda de sílaba (quase que) o dobro de vezes do que aqueles que têm ensino superior (pessoas que estudaram até fundamental aplicam a queda de sílaba $31,5 \%$, enquanto que os que cursaram o ensino superior aplicam $16,4 \%$ ). Com relação à Faixa Etária, as taxas de aplicação são muito parecidas em Campinas (pessoas na faixa de 20 a 35 anos aplicam 25,2\%, enquanto que informantes com mais de 50 anos aplicam $23,5 \%$ ), com uma diferença de $1,7 \%$ entre os fatores; em Capivari, os mais jovens aplicam $5,1 \%$ mais do que os mais velhos (de 20 a 35 anos, a porcentagem de aplicação foi de $19,7 \%$, enquanto que pessoas com mais de 50 aplicaram $14,6 \%$ ).

\subsection{Resumo}

A questão geral que norteou este trabalho foi que o processo seria mais aplicado na cidade de Capivari do que em Campinas, visto que há mais contextos de aplicação naquela cidade (com base nos resultados de Leal 2006) do que em outros dialetos (cf. Alkmim \& Gomes 1982, Battisti 2004 e Pavezi 2006a para haplologia). No entanto, esta hipótese inicial (cf. subseção 4.1.4.2.5) não foi confirmada, pois a queda de sílaba foi aplicada mais vezes em Campinas. Uma hipótese a ser investigada é verificar se este resultado pode ser atribuído à variável Informantes, selecionada nas duas cidades (e também na rodada Geral). Ao analisar cada um dos informantes, vimos que este resultado (oposto ao esperado) poderia ser explicado pelas idiossincrasias de 9 pessoas que ou aplicaram muito ou desfavoreceram muito a queda de sílaba - estão nos dois extremos da tendência ao processo. Houve 5 informantes que favoreceram excessivamente o processo e, dentre eles, 3 são campineiros - isto é, um grande favorecimento em Campinas. Os outros 4 informantes desfavoreceram a queda de sílaba, e 3 são capivarianos - ou seja, grande desfavorecimento em Capivari. Em outras palavras, dos 5 informantes primeiramente citados, 4 "empurram para cima" o favorecimento em Campinas; das outras 4 pessoas, 3 "puxam para baixo" o desfavorecimento em Capivari. 
$\mathrm{Na}$ tabela abaixo, apresento as tendências dos fatores em cada uma das variáveis linguísticas, de modo a resumir quais favorecem, desfavorecem ou são neutros ao processo, de acordo unicamente com peso relativo; para as variáveis sociais, comparo as frequências: 105

Tabela 53 - Resumo das tendências das fatores em Capivari e Campinas

\begin{tabular}{|c|c|c|c|c|}
\hline & variáveis & fatores & Capivari & Campinas \\
\hline \multirow[t]{24}{*}{ linguísticas } & \multirow{7}{*}{ Igualdade de Segmentos } & $\mathrm{C}=\mathrm{V}=$ & \multirow{7}{*}{ não selecionada } & favorece \\
\hline & & $\mathrm{C}=\mathrm{V} \#$ & & favorece \\
\hline & & C\#vozV= & & neutro \\
\hline & & C\#vozV\# & & neutro \\
\hline & & C\#nasalV= & & desfavorece \\
\hline & & C\#nasalV\# & & desfavorece \\
\hline & & C\#distr. & & inconclusivo \\
\hline & \multirow{5}{*}{$\begin{array}{l}\text { Cavidade Oral } \\
\text { das Consoantes }\end{array}$} & $t+t$ & \multirow{5}{*}{ não selecionada } & \multirow{5}{*}{ não selecionada } \\
\hline & & $s+s$ & & \\
\hline & & $p+p$ & & \\
\hline & & $f+f$ & & \\
\hline & & $k+k$ & & \\
\hline & \multirow{6}{*}{$\begin{array}{c}\text { Cavidade Oral das } \\
\text { Consoantes com [nasal] }\end{array}$} & $t+t$ & favorece & favorece \\
\hline & & $s+s$ & favorece & favorece \\
\hline & & $p+p$ & inconclusivo & inconclusivo \\
\hline & & $f+f$ & inconclusivo & inconclusivo \\
\hline & & $k+k$ & favorece & desfavorece \\
\hline & & $n+n$ & desfavorece & desfavorece \\
\hline & \multirow{6}{*}{$\begin{array}{l}\text { Cavidade Oral } \\
\text { das Vogais }\end{array}$} & ee & neutro & favorece \\
\hline & & ০० & favorece & favorece \\
\hline & & aa & desfavorece & desfavorece \\
\hline & & ea & favorece & favorece \\
\hline & & oa & favorece & favorece \\
\hline & & oe & neutro & favorece \\
\hline
\end{tabular}

105 As tendências marcadas em cinza claro na Tabela 53 indicam igualdades em Capivari e Campinas; as marcações em cinza escuro são tendências semelhantes nas duas cidades. Células em branco representam tendências diferentes nas duas cidades ou resultados inconclusivos. 


\begin{tabular}{|c|c|c|c|c|}
\hline & & eo & inconclusivo & inconclusivo \\
\hline & & ae & desfavorece & desfavorece \\
\hline & & ao & desfavorece & desfavorece \\
\hline & \multirow{7}{*}{ Estrutura Silábica } & $C V+C V$ & favorece & neutro \\
\hline & & $\mathrm{CV}+\mathrm{O}$ & neutro & favorece \\
\hline & & $\mathrm{CCV}+\mathrm{CCV}$ & inconclusivo & inconclusivo \\
\hline & & $\mathrm{CCV}+\mathrm{O}$ & neutro & neutro \\
\hline & & $\mathrm{CVC}+\mathrm{CVC}$ & inconclusivo & inconclusivo \\
\hline & & $\mathrm{CVC}+\mathrm{O}$ & desfavorece & desfavorece \\
\hline & & $0+0$ & inconclusivo & inconclusivo \\
\hline & \multirow{8}{*}{ Métrica } & $x \cdot \cdots \# \bullet$ & inconclusivo & inconclusivo \\
\hline & & $x \cdot \cdots \# c$ & inconclusivo & inconclusivo \\
\hline & & $x \cdots \# y$ & inconclusivo & inconclusivo \\
\hline & & $x \cdot \cdots \# x$ & inconclusivo & inconclusivo \\
\hline & & $x \cdot \# \cdot$ & neutro & neutro \\
\hline & & $x \cdot \# c$ & favorece & favorece \\
\hline & & $x \cdot \# y$ & favorece & favorece \\
\hline & & $x \cdot \# x$ & desfavorece & desfavorece \\
\hline & \multirow{3}{*}{ Prosódia } & entre Is & desfavorece & desfavorece \\
\hline & & entre $\Phi \mathrm{s}$ & favorece & favorece \\
\hline & & entre Cs ( $\Phi r)$ & neutro & neutro \\
\hline & \multirow{3}{*}{ Número de Sílabas } & $2 \sigma s$ & desfavorece & \multirow{3}{*}{ não selecionada } \\
\hline & & $3 \sigma s$ & neutro & \\
\hline & & 4 os ou mais & favorece & \\
\hline & \multirow{3}{*}{$\begin{array}{l}\text { Frequência de } \\
\text { Uso de Palavras }\end{array}$} & alta & \multirow{3}{*}{ não selecionada } & neutro \\
\hline & & média & & favorece \\
\hline & & baixa & & desfavorece \\
\hline \multirow{6}{*}{ sociais } & \multirow{2}{*}{ Escolaridade } & fundamental & aplica igual & aplica mais \\
\hline & & superior & aplica igual & aplica menos \\
\hline & \multirow{2}{*}{ Gênero } & masculino & aplica mais & aplica mais \\
\hline & & feminino & aplica menos & aplica menos \\
\hline & \multirow{2}{*}{ Faixa Etária } & $20-35$ & aplica mais & aplica igual \\
\hline & & mais de 50 & aplica menos & aplica igual \\
\hline
\end{tabular}




\subsection{Duas cidades, duas regras?}

Na seção 8, consideramos três tipos de comparações entre os fatores das variáveis de Capivari e de Campinas, quais sejam: iguais (fatores com tendências e pesos relativos iguais nas duas cidades); semelhantes (fatores com tendências iguais, mas com uma frequência de aplicação maior numa cidade do que na outra); e diferentes (fatores com tendências distintas nas duas cidades; ainda, se uma variável foi selecionada numa cidade e não foi em outra, também consideramos que a atuação da variável é diferente - já que interfere na cidade em que foi selecionada e não tem nenhuma atuação na cidade que não foi selecionada). Nas descrições apresentadas nas subseções 8.1, 8.2 e 8.3 anteriores (e resumidas em 8.4), pudemos verificar que há distinções nos dialetos de Capivari e Campinas no que concerne à aplicação da queda de sílaba. Para facilitar a visualização das diferenças, semelhanças e igualdades nas duas cidades, apresento um resumo na tabela a seguir, que leva em conta a comparação dos pesos relativos (para as variáveis linguísticas) e frequências (para as variáveis sociais): 
Tabela 54 - Resumo das diferenças, semelhanças e igualdades em Capivari e Campinas

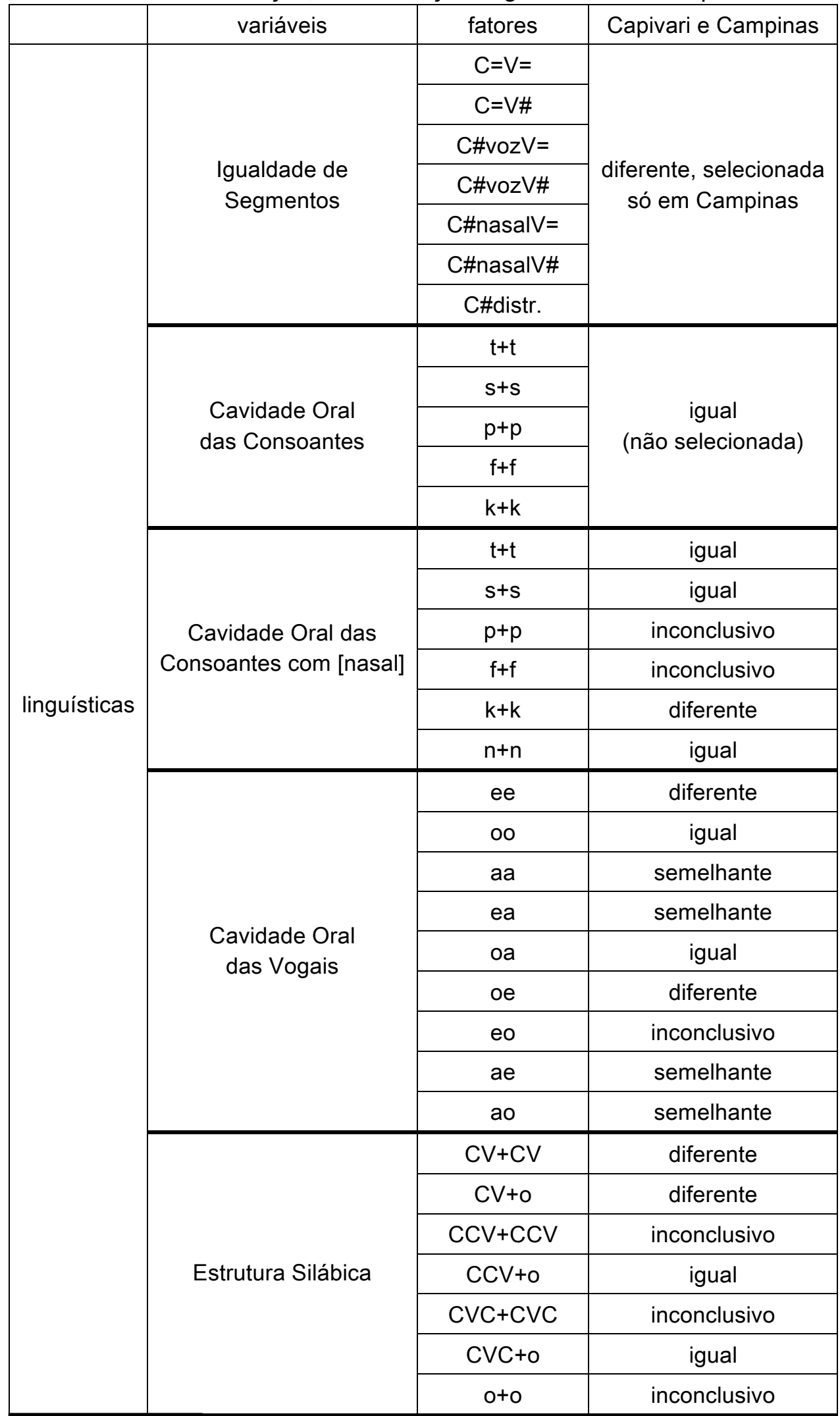




\begin{tabular}{|c|c|c|c|}
\hline & \multirow{8}{*}{ Métrica } & $x \cdot \bullet \# \bullet$ & inconclusivo \\
\hline & & $x \cdot \cdots \# c$ & inconclusivo \\
\hline & & $x \cdot \cdots \# y$ & inconclusivo \\
\hline & & $x \cdot \cdots \# x$ & inconclusivo \\
\hline & & $x \cdot \# \cdot$ & igual \\
\hline & & $x \cdot \# c$ & semelhante \\
\hline & & $x \cdot \# y$ & semelhante \\
\hline & & $x \cdot \# x$ & semelhante \\
\hline & \multirow{3}{*}{ Prosódia } & entre Is & igual \\
\hline & & entre $\Phi \mathrm{s}$ & igual \\
\hline & & entre Cs $(\Phi r)$ & igual \\
\hline & \multirow{3}{*}{ Número de Sílabas } & 2 os & \multirow{3}{*}{$\begin{array}{c}\text { diferente, selecionada } \\
\text { só em Capivari }\end{array}$} \\
\hline & & $3 \sigma s$ & \\
\hline & & 4 os ou mais & \\
\hline & \multirow{3}{*}{$\begin{array}{l}\text { Frequência de } \\
\text { Uso de Palavras }\end{array}$} & alta & \multirow{3}{*}{$\begin{array}{c}\text { diferente, selecionada } \\
\text { só em Capivari }\end{array}$} \\
\hline & & média & \\
\hline & & baixa & \\
\hline \multirow{6}{*}{ sociais } & \multirow{2}{*}{ Escolaridade } & fundamental & diferente \\
\hline & & superior & diferente \\
\hline & \multirow{2}{*}{ Gênero } & masculino & igual \\
\hline & & feminino & igual \\
\hline & \multirow{2}{*}{ Faixa Etária } & $20-35$ & diferente \\
\hline & & mais de 50 & diferente \\
\hline
\end{tabular}

Como foi visto em 2.1, integramos teoria fonológica e variação de acordo com a tendência e a produtividade de queda de sílaba:

- Variável com uma mesma tendência (favorecimento, neutralidade ou desfavorecimento) e mesma produtividade: as características de queda de sílaba são consideradas iguais em Capivari e em Campinas;

- Variável com tendências iguais mas os pesos relativos são diferentes: há uma mesma regra que tem uma produtividade diferente nas duas cidades; e 
- Finalmente, tendências diferentes (e, consequentemente, pesos relativos diferentes): há uma regra para Capivari e outra regra para Campinas.

A produtividade do processo (tendências iguais com pesos relativos diferentes) indicam que a aplicação é maior numa cidade e menor em outra, mas as tendências são as mesmas - há uma mesma regra. Tendências diferentes indicam que há uma diferença no contexto de aplicação da regra e, consequentemente, há duas regras diferentes nas duas cidades - um fator pode favorecer o processo em uma cidade, e desfavorecer em outra.

Voltando à Tabela 54, temos que Igualdade de Segmentos, Número de Sílabas, Frequência de Uso de Palavras, Escolaridade e Faixa Etária são claramente distintos nas duas cidades. Por outro lado, Cavidade Oral das Consoantes sem Distinção de [nasal], Prosódia e Gênero são claramente iguais. Nas demais as variáveis, encontramos uma distribuição menos clara. Por outro lado, Cavidade Oral das Consoantes com distinção do traço [nasal] tem tendências e produtividades praticamente idênticas para coronais orais (favorecedoras), nasais (desfavorecedoras) e labiais (em ambas as cidades, a produtividade deste contexto é muito baixa); apesar destas igualdades na variável Cavidade Oral das Consoantes com Distinção de [nasal], no entanto, as tendências são opostas para dorsais, o que indica duas regras distintas. No que concerne à Cavidade Oral das Vogais, verificamos que há: (i) igualdades (como no favorecimento nos contextos [dorso-labial + dorso-labial] e [dorso-labial + dorsal]), ou seja, os fatores têm uma mesma tendência e produtividade; (ii) semelhanças (como nos contextos com uma [dorsal] na primeira sílaba e contextos [coronal + dorsal], casos que desfavorecem o processo), isto é, a tendência é a mesma, mas a produtividade é diferente; e (iii) finalmente, os contextos [coronal + coronal] e [dorso-labial + coronal] são diferentes nas duas cidades, uma vez que há uma neutralidade em Capivari e um favorecimento em Campinas. Observando-se (i), (ii) e (iii), concluímos que Cavidade Oral das Vogais tem efeito diferente nas duas cidades. Quanto à Métrica, vimos que há uma diferença na produtividade, mas não na regra: contextos $[x \cdot \# y]$ e $[x \cdot \#$ c] favorecem o processo, $[\mathrm{x} \cdot \# \cdot]$ são neutros $\mathrm{e}[\mathrm{x} \cdot \# \mathrm{x}]$ desfavorecem - todas as três com uma mesma tendência nas duas cidades.

Finalmente, como vimos no Capítulo III, em que abordamos a definição do processo 
fonológico, o nível mais importante para definir a queda de sílaba é o segmental, mais especificamente, as consoantes, o que foi corroborado pelo estudo piloto deste trabalho (cf. 5.1). Vimos também (cf. subseção 8.2.1) que as consoantes coronais orais e as nasais têm comportamentos muito parecidos nas duas cidades; no entanto, as dorsais têm comportamento oposto: há um favorecimento do processo com estes segmentos em Capivari, enquanto que o processo é inibido em Campinas. E se o que define a queda de sílaba é o contexto consonantal, há uma diferença nas regras das duas cidades: as tendências e as produtividades das coronais e das nasais são (quase que) idênticas (para as coronais [-contínuo], os pesos relativos foram 0,653 e 0,644 em Capivari e em Campinas, respectivamente; para as coronais [+contínuo], $p=0,626$ em Capivari e $p=0,652$ em Campinas; para as nasais, $p=0,3$ em Capivari e $p=0,33$ em Campinas). Interessantemente, as labiais ([-contínuo] e [+contínuo]) tiveram ocorrências baixas, em ambas as cidades, o que indica que estes contextos não são tão produtivos, tanto em Capivari quanto em Campinas. Assim, somente observando coronais orais, nasais e labiais, poderíamos concluir que há uma mesma regra nas duas cidades. No entanto, há uma expansão no contexto de queda de sílaba em Capivari se comparado à Campinas com contextos com duas dorsais: na primeira cidade, há um favorecimento do processo, com $p=0,584$, enquanto que na segunda há um desfavorecimento, com $p=0,343$, e consequentemente, uma produtividade diferente nas duas cidades. A regra se aplica de modo distinto: há um favorecimento com dorsais para capivarianos e desfavorecimento para campineiros. 


\section{CAPÍTULO IX}

\section{Algumas questões linguísticas}

Neste capítulo, discuto as seguintes questões linguísticas relacionadas à queda de sílaba: o papel da métrica (ver 9.1); o papel da frase fonológica (cf. 9.2); o tamanho da palavra (sujeita à queda) e recuperação de informação (cf. subseção 9.3); e a estrutura silábica versus estrutura interna dos segmentos (ver 9.4).

\subsection{Métrica}

Nesta variável, propusemos oito fatores: em quatro deles, a primeira palavra tem uma sílaba forte seguida de duas fracas $[\mathrm{x} \cdots \# \cdot],[\mathrm{x} \cdots \# \mathrm{c}],[\mathrm{x} \cdots \# \mathrm{y}]$ e $[\mathrm{x} \cdot \# \mathrm{x}] \mathrm{e}$, nos outros quatro, a primeira palavra tem uma sílaba forte seguida de uma fraca $[x \cdot \# \cdot]$, [ $\mathrm{x} \cdot \# \mathrm{c}],[\mathrm{x} \cdot \# \mathrm{y}]$ e $[\mathrm{x} \cdot \# \mathrm{x}]$. Não pudemos interpretar as quatro primeiras sequências com dátilos, pois as frequências foram muito baixas nestes fatores. ${ }^{106}$ Os resultados dos contextos em que a primeira palavra tem uma sílaba forte seguida de uma fraca, no entanto, levantam algumas questões para as propostas métricas atuais.

A literatura sobre o assunto é concorde que os acentos são atribuídos não de um modo absoluto, mas que cada sílaba recebe um grau de acento em relação a outras batidas numa mesma estrutura rítmica: o acento tem uma natureza relacional (cf. Hayes 1995: 3778 e subseção 2.2.3). Na hierarquia apresentada em (206) (cf. subseção 4.1.4.1.3 e referências ali citadas), há quatro graus de acento, como reescrevo abaixo:

(278) Hierarquia de acento:

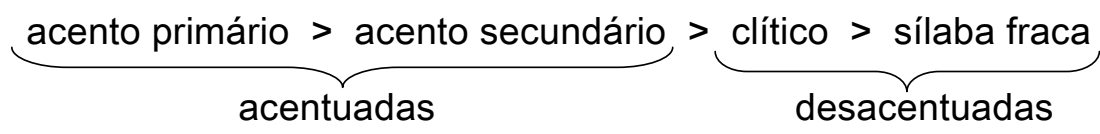

106 As ocorrências da rodada Geral (ver subseção 5.3.1.3), de Capivari (cf. 6.1.3) e Campinas (ver 7.1.3) foram,

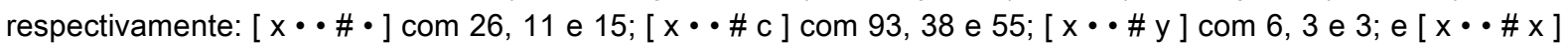
com 73, 32 e 41. 
Em (278), observamos que os graus mais altos são o acento primário e o secundário (o primário é mais forte do que o secundário); e os graus mais fracos são clítico e sílaba fraca (destes dois graus, clíticos podem ser considerados mais fortes do que sílabas fracas porque carregam acento de palavra).

Esquematicamente, ao relacionar a queda de sílaba (dos contextos em que a primeira palavra tem uma estrutura acentual $[x \cdot]$ ) à hierarquia de acento em (278), temos:

Tabela 55 - Relação entre a queda de sílaba e a hierarquia de acento em que primeira palavra é $[\mathrm{x} \cdot])$

\begin{tabular}{|c|c|c|c|}
\hline contexto & \multicolumn{2}{|c|}{ resultado } & expectativa de queda de sílaba \\
\hline$(1) \mathrm{x} \cdot \# \mathrm{x}$ & choque de acentos 1ário & $\mathrm{x} \# \mathrm{x}$ & evite sempre \\
\hline$(2) \mathrm{x} \cdot \# \mathrm{y}$ & choque de 1ário e 2ário & $\mathrm{x} \# \mathrm{y}$ & evite (menos do que (1)) \\
\hline$(3) \mathrm{x} \bullet \# \mathrm{c}$ & forte + clítico & $\mathrm{x} \# \mathrm{c}$ & implemente (menos do que (4)) \\
\hline$(4) \mathrm{x} \cdot \# \cdot$ & forte + fraca & $\mathrm{x} \# \cdot$ & implemente sempre \\
\hline
\end{tabular}

Como vemos na Tabela 55, a expectativa é que contextos em que há uma sílaba forte seguida de uma fraca na primeira palavra e um acento primário na segunda palavra [ $\mathrm{x} \cdot \# \mathrm{x}]$ ou secundário $[\mathrm{x} \cdot \# \mathrm{y}]$ tenham, ao menos, resultados semelhantes, desfavorecendo a queda de sílaba: a aplicação do processo resulta em sequências rítmicas ruins com relação ao PAR [ $\mathrm{x} \# \mathrm{x}$ ] e [ $\mathrm{x} \# \mathrm{y}$ ], já que gera duas sílabas fortes adjacentes um choque acentual. Com relação às sequências $[x \cdot \# c]$ e $[x \cdot \# \cdot]$, uma vez que clíticos e sílabas fracas não carregam acento, ambas deveriam favorecer o processo: nestes dois contextos, há duas sílabas fracas adjacentes, uma sequência ritmicamente ruim, de acordo com o PAR, e a implementação da queda de sílaba resultaria em sequências ritmicamente melhores $[x \# c]$ e $[x \# \cdot]$ do que as originais $[x \cdot \# c]$ e $[x \cdot \# \bullet]$.

O resultado obtido para o fator $[\mathrm{x} \cdot \# \mathrm{c}$ ] nas duas cidades corrobora as previsões da Tabela 55 e está de acordo com o PAR: há um favorecimento do processo neste fator (estrutura $[\mathrm{x} \bullet$ ] seguida de clítico fonológico) em Capivari e em Campinas. Na estrutura [ $\mathrm{x} \bullet$ \# $\mathrm{x}$ ] que resulta em [ $\mathrm{x} \# \mathrm{x}$ ], vimos que choque acentual não bloqueia a queda de sílaba, mas desfavorece o processo nas duas cidades, também de acordo com o PAR (Selkirk 1984: 52), e corrobora os resultados de haplologia de Tenani (2002) e de queda de sílaba 
de Leal (2006).

A surpresa ocorre com as sequências $[\mathrm{x} \cdot \# \cdot]$ e $[\mathrm{x} \cdot \# \mathrm{y}]$. A expectativa era que contextos $[\mathrm{x} \cdot \# \cdot \boldsymbol{B}]$ tivessem um resultado semelhante às sequências $[\mathrm{x} \cdot \# \mathrm{c}$ ], como apresentado na Tabela 55, por dois motivos:

(a) Ou deveriam ser iguais, com favorecimento da queda de sílaba nos dois contextos (já que as duas sílabas não têm acento);

(b) Ou o contexto [ $\mathrm{x} \cdot \mathrm{\#} \mathrm{c}$ ] favoreceria a queda de sílaba um pouco menos do que a sequência $[x \cdot \# \cdot$ ], levando-se em conta que um clítico pode ser considerado mais acentuado do que uma sílaba fraca (um clítico carrega acento de palavra enquanto que uma sílaba fraca nunca tem acento em nenhum nível) - cf. referências na subseção 2.2.3.

Nas subseções de resultado para Métrica, ${ }^{107}$ vimos que a sequência $[\mathrm{x} \cdot \# \cdot$ ] é neutra, não favorece o processo, levando a maiores violações do PAR. Além disso, no que concerne ao padrão de aplicação de $[x \cdot \# \cdot]$ em comparação a $[x \cdot \# c]$, temos que, em cada um dos contextos, há uma sílaba com acento seguida de duas sem acento. A diferença entre os resultados das duas variáveis é que, embora ambas sejam sílabas fracas, o comportamento foi diferente $([\mathrm{x} \cdot \# \mathrm{c}]$ favorece o processo, mas $[\mathrm{x} \cdot \# \cdot]$ é neutro, o que não está de acordo com a expectativa apresentada na Tabela 55).

Outro resultado interessante foi o da sequência $[\mathrm{x} \cdot \# \mathrm{y}$ ]. A expectativa apresentada na Tabela 55 era que a queda de sílaba fosse desfavorecida, da mesma forma que num contexto $[x \cdot \# x]$, pois a aplicação do processo criaria um choque acentual. No entanto, este contexto $[\mathrm{x} \cdot \# \mathrm{y}$ ] favorece a queda de sílaba. Em outras palavras, visto que as sílabas finais dos contextos $[\mathrm{x} \cdot \# \mathrm{x}] \mathrm{e}[\mathrm{x} \cdot \mathrm{\#} \mathrm{y}]$ carregam acento, a implementação do processo causa choque acentual, o que vai contra o PAR.

Conforme me foi apontado por Santos (comunicação pessoal), este mesmo padrão é encontrado em outros processos entre palavras, a saber a degeminação e a retração acentual. A restrição métrica para a degeminação entre palavras é que o processo ocorre

107 Cf. em 5.3.1.3 os resultados da rodada geral, em 6.1.3 da rodada de Capivari e em 7.1.3 da rodada de Campinas. 
entre duas sílabas fracas (menino horrível > meni[no]rrível), mas não se a segunda sílaba portar acento primário (ovo oco $>{ }^{*} \mathrm{O}[\mathrm{vo}] \mathrm{co}$ ) - cf. Santos (2007). No caso de menino operário, em que a primeira sílaba da segunda palavra recebe acento secundário no português brasileiro, o processo pode ocorrer (meni[no]perário), o que mostra que para a regra, interessa apenas o acento primário. O mesmo ocorre com retração acentual: só há aplicação entre sílabas portadoras de acento primário. Uma sequência de acento primário mais acento secundário não leva à retração acentual, como pode se ver no exemplo café operário *['ka.fє.,o.pe.'ra.riw]. Tal fato leva-a a sugerir que pode ser o caso de que, no português brasileiro, a hierarquia em (278) deva ser:

(279) Hierarquia de acento:

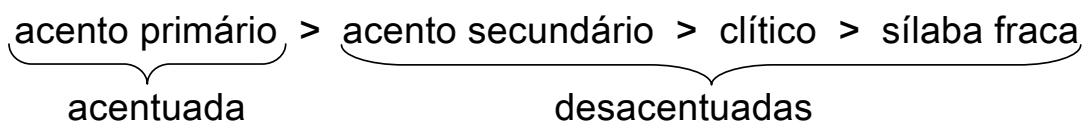

Em (279), o que se sugere é que o acento secundário também seja considerado como uma sílaba fraca no português brasileiro. Dessa forma, teríamos que uma sílaba fraca entre duas sílabas fortes $[\mathrm{x} \cdot \# \mathrm{x}$ ] desfavorece a queda de sílaba, pois há dois acentos adjacentes; para os outros contextos - uma sílaba fraca entre um acento primário e um secundário [ $\mathrm{x} \cdot \# \mathrm{y}$ ], um lapso de 2 sílabas (em que a última é um clítico) [ $\mathrm{x} ・ \# \mathrm{c}$ ] e lapso de 2 sílabas fracas [ $x \cdot \# \cdot$ ] - a única restrição seria não desfavorecer, pois, se o resultado da aplicação de queda de sílaba nestes contextos não causa choque acentual, a tendência pode tanto ser ao favorecimento quanto à neutralidade da aplicação do processo.

\subsection{Prosódia}

Nesta variável, pudemos verificar que a fronteira entre duas frases fonológicas é (levemente) mais propícia à queda de sílaba, o que corrobora os resultados de Battisti (2004), Pavezi (2006a) e Leal (2006). Na fronteira entre dois grupos clíticos (que também pode ser dentro de frase fonológica reestruturada), não há qualquer efeito; finalmente, entre sentenças (frases entonacionais), o processo é (levemente) desfavorecido. E estes resultados para os três níveis estudados são os mesmos nas duas cidades. 
Assim, uma primeira interpretação dos resultados é que a hierarquia prosódica não interfere no processo, pois ele pode ocorrer em qualquer nível (cf. Tenani 2002, Pavezi 2006a e Leal 2006) e, além disso, vimos que os resultados dos fatores não são muito polarizados - a frase fonológica influencia levemente na queda de sílaba.

Como reportamos em 3.2.4, os dados de Tenani (2002) apontam que a aplicação de haplologia se dá inversamente aos níveis prosódicos; assim, quanto mais baixo for o constituinte, maior é a taxa de implementação do processo. Estes resultados não foram corroborados em nossos dados, pois a queda de sílaba foi levemente favorecida entre frases fonológicas (o que corrobora Battisti 2004, Pavezi 2006a, para a haplologia, e Leal 2006, para a queda de sílaba).

Chamamos a atenção para o fato de que, como vimos em 8.5, Capivari e Campinas têm regras diferentes de queda de sílaba; mesmo assim, nas duas cidades, há um pequeno favorecimento entre frases fonológicas. Para os dialetos de Porto Alegre (cf. Battisti 2004), de São José do Rio Preto e de São Paulo (ambos os dialetos, cf. Pavezi 2006a), é também entre frases fonológicas que a haplologia mais ocorre. Estes resultados podem ser pistas de que a tendência ao apagamento entre duas frases fonológicas é uma característica do português brasileiro: o primeiro dialeto é do sul do país, a variedade de Porto Alegre (Battisti 2004); o outro é do norte do estado de São Paulo, o dialeto de São José do Rio Preto (Pavezi 2006a); há ainda a variedade da capital do estado de São Paulo (Pavezi 2006a); e finalmente, o favorecimento de frase fonológica foi encontrado em duas cidades próximas do interior paulista, Capivari e Campinas - mas vale lembrar que estas duas cidades têm regras segmentais diferentes de aplicação do processo.

Dado que há neutralidade em grupo clítico, um (leve) desfavorecimento em frase entonacional e (leve) favorecimento apenas em frase fonológica, levantamos a hipótese de ser este um processo característico de frase fonológica no português brasileiro. Se estivermos na direção certa, a queda de sílaba pode ser utilizada na investigação de processos de interface fonologia-sintaxe (cf. Abousalh 1997, Santos 2002, 2003, 2009, Nunes \& Santos 2009). 


\subsection{Tamanho da palavra}

Nos resultados da variável de Número de Segmentos (selecionada apenas em Capivari), vimos que a tendência de aplicação é diretamente proporcional ao tamanho da palavra: dissílabos desfavorecem (levemente) o processo, trissílabos são neutros e palavras com 4 sílabas ou mais favorecem (levemente) a queda de sílaba.

Podemos associar estes resultados com a recuperação da informação, pelo ouvinte, do que "não está lá". Observe os exemplos a seguir, em que há aplicação de queda de sílaba e, originalmente, a primeira palavra do exemplo (280) tem 4 sílabas e a do exemplo (281) tem duas sílabas:

(280) [dẽ.si.'da] do alho 1a palavra: 4 sílabas

(281) ['dẽ] do alho 1a palavra: 2 sílabas

Em (280), o processo é um pouco favorecido (a palavra tem 4 sílabas) e, em (281), a queda de sílaba é levemente desfavorecida (a palavra sujeita à queda é um dissílabo). Comparando-se as duas aplicações, a informação apagada no exemplo (280) é muito mais facilmente recuperada, e o ouvinte pode deduzir que a primeira palavra só pode ser densidade; a produção em (281) pode ser ambígua, já que ['dẽ] do alho pode se referir a dentro do alho ou a dente do alho; assim, o ouvinte está muito mais dependente do contexto em (281) do que em (280).

Observe os exemplos a seguir:

$\begin{array}{lll}\text { (282) } & \text { [ar.ki.'te] de Campinas } & \text { 1a palavra: } 4 \text { sílabas } \\ \text { (283) } & \text { ['ga] de Capivari } & \text { 1a palavra: } 2 \text { sílabas }\end{array}$

Assim como no par apresentado em (280) e (281), a informação perdida com a aplicação da queda de sílaba em (282) pode ser mais ser mais facilmente recuperada do que em (283), também por causa do tamanho da palavra. Note que é mais difícil de se encontrar uma palavra que comece com [ar.ki.'tc]. Por outro lado, ['ga] em (283) pode se referir a garra, galo, gafe, etc. (considerando-se apenas palavras que começam por ['ga] 
como sílaba forte).

A diferença entre (280) [,dẽ.si. 'da] do alho e (281) ['dẽ] do alho, de um lado, e (282) [ar.ki. 'te] de Campinas e (283) ['ga] de Capivari, de outro, é que, no segundo par, é apagado também um morfema. Assim, em (282), a informação apagada pode ser arquitetO de Campinas ou arquitetA de Campinas; da mesma forma, em (283), os sintagmas podem ser gatO de Capivari ou gatA de Capivari. Mesmo com o apagamento de um morfema, a queda é permitida, e é muito mais simples para o ouvinte recuperar arquitet do que gat.

Podemos concluir que a condição de recuperação informacional depende do tamanho da palavra sujeita à queda - quanto mais sílabas, mais fácil se torna recuperar a palavra original, e talvez seja essa a razão de encontrarmos um padrão na queda proporcional ao tamanho da palavra.

\subsection{Estrutura silábica e geometria de traços: Sílabas ou segmentos?}

Nesta subseção discuto algumas questões sobre um fato curioso sobre a queda de sílaba: é um processo que tem como alvo a sílaba (pois o resultado é o apagamento desta unidade); entretanto, o gatilho da regra não é silábico, mas sim segmental - mais especificamente, consonantal. Em outras palavras, é a identidade de determinados traços consonantais da primeira posição do ataque de duas sílabas que importa para que o processo ocorra; nem os traços vocálicos interessam, nem a consoante num ataque ramificado. De qualquer forma, o processo parece depender de dois elementos (silábicos ou intrassilábicos) idênticos e discutimos também o OCP (cf. 2.2.2).

Assumimos a teoria da estrutura da sílaba de Selkirk (1982) (cf. subseção 2.2.2), repetida em (284): 
(284) Representação da estrutura da sílaba, adaptado de Selkirk (1982: 331)

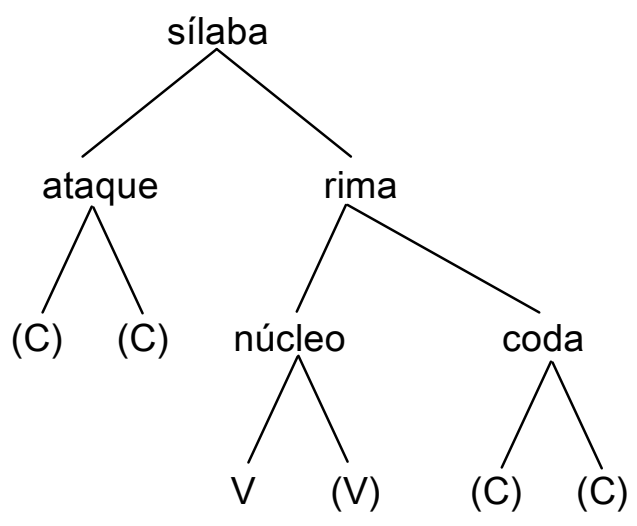

Como vemos em (284), a sílaba está dividida em ataque e rima, sendo que a rima se divide ainda em outros dois constituintes: o núcleo e a coda. $O$ ataque, o núcleo e a coda podem ser ramificados, e estes constituintes são todos binários para Selkirk (1982). Em (284), os parênteses indicam que as duas posições de ataque, as duas de coda e a segunda posição da rima não precisam ser necessariamente preenchidas; assim, temos exemplos do português brasileiro de estruturas de sílabas $\mathrm{V}$ (como no verbo ser flexionado É), CV (como em PÉ), CCV (por exemplo, PREto), CVC (PERto), CVV (PElto), VVCC (EINStein), CCVV (BREU), etc.

Se o ataque, a coda e a segunda posição da rima não têm necessidade de aparecer em todas as sílabas, como representado na notação em (284), a única posição da sílaba que deve ser obrigatoriamente preenchida é o núcleo (peak), ocupada, nas diversas línguas, por uma vogal, ou de um modo mais abrangente, por um segmento vocálico. ${ }^{108} \mathrm{Em}$ outras palavras, a vogal que preenche o núcleo é a parte fundamental da sílaba.

Um primeiro problema que se coloca é o fato de que a queda de sílaba "olha" para um segmento que não está na posição fundamental da sílaba; mais do que isso, o processo deve desprezar estes segmentos - as vogais - a fim de poder "enxergar" alguma identidade entre as consoantes. Para ilustrar a questão com duas sílabas CV, temos:

108 Os segmentos / $r /$ e /// são [+vocálicos] e podem também ser o núcleo de uma sílaba, como no inglês americano Jenifer > Jeni[fr] (cf. Clements \& Keyser 1983: 189, para quem / $\varepsilon$, I, r/ constituem picos silábicos nesta palavra). De acordo com Goldsmith (2011), no Imdlawn Tashlhiyt Berber (dialeto berber falado no Marrocos), o feminino da terceira pessoa do singular do verbo 'puxar' é $t / / / d i$, ou seja, o /// é o núcleo da primeira sílaba. 


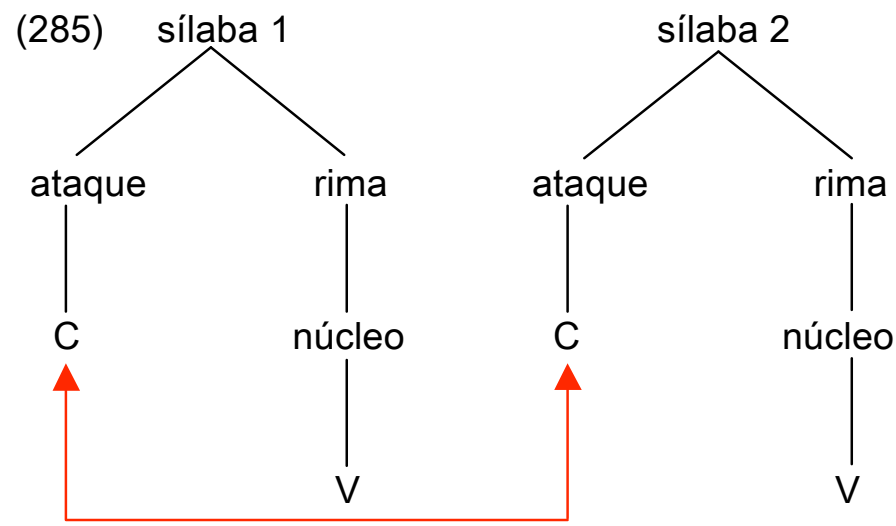

Este fato de o processo ter de ignorar as vogais para poder "enxergar" as consoantes vai de encontro à generalização de Clements \& Hume (1995: 288) dada a seguir:

It is a striking crosslinguistic generalization that consonantal place features do not appear to be able to spread as a unit from one consonant to another across vowels. (...) For example, although we common find rules in which a nasal assimilates to an adjacent consonant in all its place features, we never find rules in which a nasal assimilates to all place features of a consonant across a vowel. (grifos meus)

Os itálicos na citação acima indicam que os casos tratados pelos autores são espalhamento de traços (feature spreading), que vai de uma consoante a outra, o que não ocorre com a queda de sílaba. No entanto, mesmo não sendo um processo de assimilação (não há espalhamento de traços), mas sim um tipo de dissimilação (cf. Mercado 2001 e Plag 1998), o gatilho do processo (duas consoantes com determinados traços iguais) deve, de alguma forma, ignorar a vogal intermediária. Alguém poderia argumentar que o processo olha para os traços das consoantes e das vogais, como em:

(286) dependen(DO) DO dia

(q)

Neste caso, deveríamos tomar as sílabas $d o+d o$ como duas unidades, e não quatro; assim, o primeiro elemento do é igual e está adjacente ao segundo elemento do, o que pode resultar no apagamento de uma das unidades (silábicas) do. Assim, poderíamos 
concluir que o processo pode ocorrer com sílabas iguais, o que corroboraria o OCP: elementos (sílabas) adjacentes idênticos são proibidos.

Porém, o fato é que a queda de sílaba pode se dar com conteúdos diferentes (desde que com as consoantes do ataque tendo o mesmo ponto de $\mathrm{C}$ e [contínuo]), o que não pode ser explicado pelo OCP. Mais ainda: no caso de CCV (cf. exemplo (287)), o processo "pula" também a segunda consoante do ataque, o que mostra uma diferença das duas posições do ataque que não está capturada pelo esquema em (284), exemplificado a seguir:

(287) /tro + de/ encon(TRO) DE moto

(s)

No contexto segmental /tro + de/ acima, há não um, mas dois cruzamentos de linhas, pois há dois elementos intervenientes. Assim, o processo deve "enxergar" o ataque da primeira sílaba /t/ e o ataque da segunda sílaba /d/, "pulando" dois segmentos: a segunda consoante /r/ do ataque ramificado e a vogal da primeira sílaba /o/.

Um outro fato a ser levando em conta é que, se a queda de sílaba ignora a rima, e trata-se de uma regra de ataque, como explicar que CVC inibe a regra?

(288) /deN + dos/ orDEM DOS advogados

No contexto acima, a sílabas sujeita ao apagamento tem coda final, o que inibe a regra.

Podemos resumir as propriedades interessantes da queda de sílaba que levantam questões sobre a estrutura da sílaba com o seguinte exemplo: 
(289) /tros + de/ meu filho caiu de dois me(TROS) DE altura

(Q)

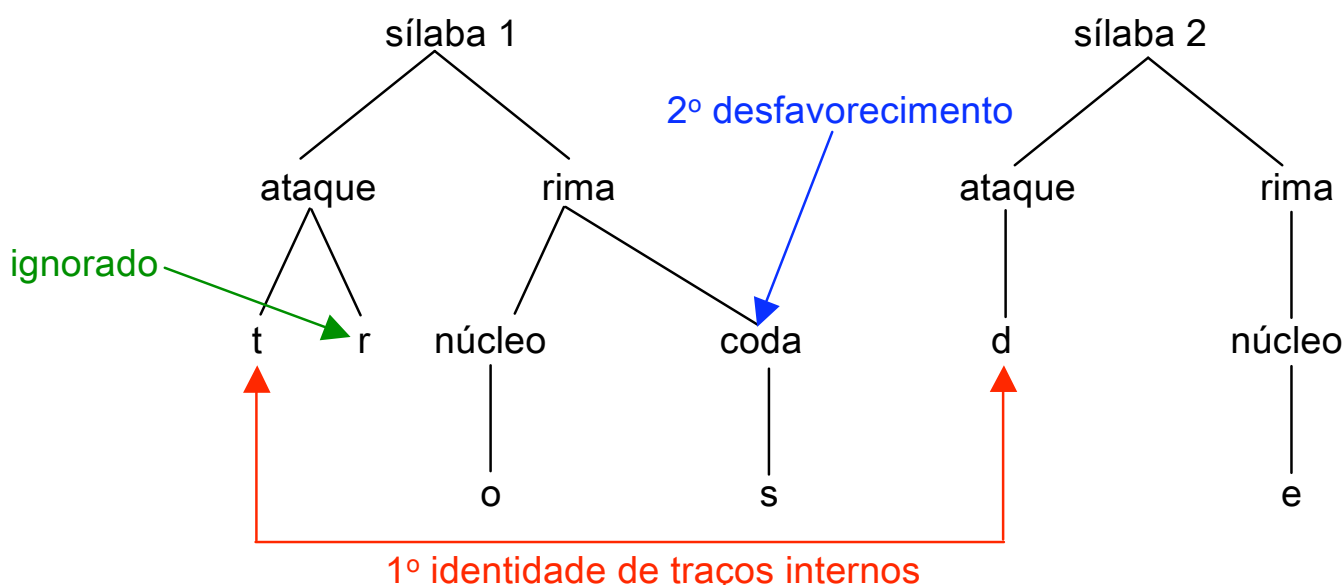

Assim, a questão a ser respondida é: se não é o OCP o desencadeador da queda de sílaba, qual é a restrição? Em outras palavras, se a identidade que o processo olha não é a das sílabas, qual(is) é(são) esta(s) unidade(s)?

A discussão a seguir tem o objetivo de relacionar a geometria de traços aos resultados de queda de sílaba para o nó de cavidade oral (o que engloba o ponto de $\mathrm{C}$ e o traço [contínuo]), para o traço [nasal] e para o traço [vozeamento] (que é dominado pelo nó [laringal]).

Observe a geometria apresentada a seguir, em que estão os nós e traços relevantes para a discussão que se segue:109

109 Os traços que não serão discutidos foram retirados do Gráfico 38 para facilitar a visualização. Cf. a árvore completa em Clements \& Hume (1995: 292) e também na subseção 2.2.1 desta tese. 


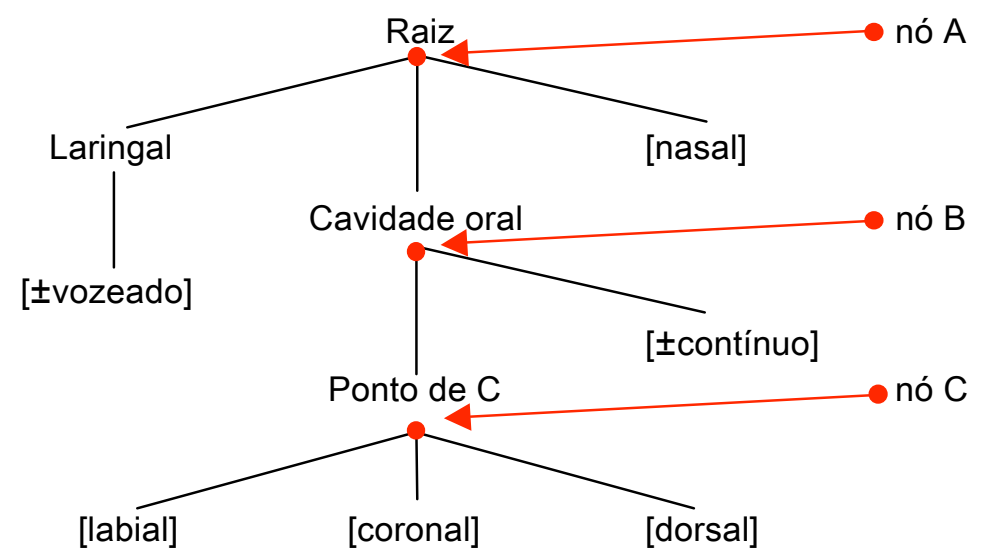

Gráfico 38- Geometria dos nós: raiz, laringal e cavidade oral (adaptado de Clements \& Hume 1995: 292)

Na subseção 2.2.1, vimos que os traços estão organizados de modo que, se uma regra fonológica se aplica num nó, todos os nós dominados também serão afetados, pois as linhas de associação agrupam constituintes (classes naturais de sons) - cf. Clements \& Hume (1995: 251). Adicionalmente, os autores (p. 50) propõem o princípio de que as regras fonológicas devem executar uma única operação (cf. 2.2.1). Unindo este princípio e a organização de traços apresentada no Gráfico 38 aos resultados obtidos no presente trabalho, quais sejam:

- traço [ \pm vozeado] (submetido ao nó laringal): se forem diferentes, não interferem na queda de sílaba (há neutralidade); se forem iguais, favorecem.

- o traço [nasal]: interfere na queda de sílaba, desfavorecendo-a;

- [ \pm contínuo] (submetido à cavidade oral): interfere na queda de sílaba, bloqueando se não houver igualdade nestes traços;

- ponto de C (submetido à cavidade oral): interfere na queda de sílaba, bloqueando se não houver igualdade neste nó,

a pergunta que buscamos responder é: em qual(is) nó(s) ou traço(s) a queda de sílaba se aplica?

Observe-se inicialmente o nó $\mathrm{C}$ que inclui o ponto de $\mathrm{C}$ e o que está abaixo dele. Os resultados (cf. Leal 2006) mostraram que não só o ponto de C é importante, mas que o traço [contínuo] também tem um papel na aplicação de queda de sílaba. Uma vez que este 
traço está acima de ponto de $C$, podemos concluir que a regra não atua no nó $C$. Leal (2006) propõe que é no nó B que o processo se baseia, pois ele inclui ponto de C e [contínuo]. No entanto, não pode ser neste nó, pois nossos resultados apontam que [nasal] interfere no processo, desfavorecendo-o, e este traço está acima do nó B (cavidade oral) o que indica que a regra de queda de sílaba depende mais do que de ponto de $\mathrm{C} \mathrm{e}$ [contínuo], ao contrário do que afirma Leal (2006).

Assim, para que a queda de sílaba "enxergue" o traço [nasal], a única opção é que o processo se aplique no nó $A$, na raiz do segmento:

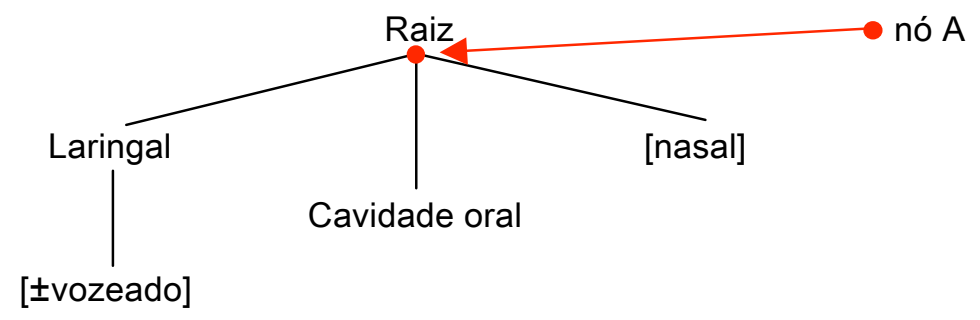

Gráfico 39- Aplicação de queda de sílaba: nó de raiz

Se a queda de sílaba se aplica ao nó A (a raiz), esta hipótese dá conta do fato que a regra "enxerga" o traço [nasal] e a cavidade oral (ponto de C e [contínuo]), como exemplifico a seguir:

(290) tem bugri(NO) NA família

(291) fazen(DO) NAda de errado (m)

Em (290), há duas consoantes com um mesmo ponto de C [coronal], um mesmo valor [-contínuo] e são duas nasais; em (291), /d+n/ diferem em [nasal], pois a primeira é oral. Em ambos os casos, o processo é desfavorecido.

No entanto, o nó de raiz também engloba o traço [vozeamento], que é dependente do nó [laringal]. Se o processo procura a igualdade no nó $A$, então casos com variação de [vozeamento] deveriam desfavorecer o processo: 
(292) /z + s/ qua(SE) CERteza

(293) $/ d+d /$ apareci(DA) DO norte
$(G)$

Em (292), há uma consoante [+vozeado] seguida de outra [-vozeado], contexto em que encontramos uma neutralidade da queda de sílaba; em (293), ambas as consoantes têm um mesmo valor [+contínuo], casos em que há um favorecimento do processo.

A resposta para a questão pode estar no resumo dos fatos: enquanto que pontos de C diferentes e [contínuo] diferentes bloqueiam o processo, uma diferença em [nasal] ou [vozeamento] não bloqueia o processo, apenas desfavorece ou mantém-se neutro.

Assim, a questão que se coloca é que parece que cada nó/traço tem um peso diferente no processo. A discussão que desenvolveremos a seguir diz respeito questões:

1. Qual(is) é(são) o(s) nó(s) ou traço(s) que impõe $(\mathrm{m})$ o bloqueio do processo?

2. Qual(is) é(são) o(s) nó(s) ou traço(s) responsável(is) pela variação da queda de sílaba? Em outras palavras, qual(is) é(são) o(s) nó(s) ou traço(s) responsável(is) pelo favorecimento, neutralidade e desfavorecimento do processo?

Voltando ao Gráfico 38, temos que a cavidade oral (nó B) é o que rege a queda de sílaba, pois é no ponto de C e no traço [contínuo] que está o contexto de queda de sílaba: se as cavidades orais das consoantes forem diferentes num desses dois traços, não há implementação do processo, como exemplifico a seguir:

(294) /d + v/ mas gostava também quanDO VInha na cidade

A produção da informante a em (294) é um dos dados do estudo piloto (cf. 5.1.1) e ilustra um contexto $/ d+v /$, com duas consoantes com cavidades orais diferentes: /d/ é uma [coronal, -contínuo] e /v/ é uma [labial, +contínuo], e neste contexto nunca houve aplicação de queda de sílaba nos dados do piloto. Quaisquer que sejam os processos fonológicos que possam ser implementados no contexto quanDO VInha, não é a queda de sílaba.

Por outro lado, os traços [nasal] e [vozeamento] não regem o processo (bloqueio ou possibilidade de aplicação), mas definem sua tendência: se há uma ou duas consoantes 
nasais no contexto, haverá um desfavorecimento; se [vozeamento] for igual, o processo é neutro. Isto significa que, apesar de ambos serem dominados pelo nó de raiz, há uma diferença de comportamento.

Ainda, além de o ponto de $\mathrm{C}$ definir a regra (juntamente com [contínuo]), os traços que estão abaixo deste nó também ditam tendências: coronais (orais) favorecem e dorsais podem favorecer (em Capivari) ou desfavorecer (em Campinas) - nada afirmamos sobre as labiais porque houve poucos tokens nestes contextos (cf. subseções 5.3.1.1.2, 6.1.1.2 e 7.1.1.2). Dessa forma, mesmo sendo traços irmãos (ou seja, todos dominados pelo nó ponto de C), [labial], [coronal] e [dorsal] têm comportamentos diferentes na queda de sílaba. ${ }^{110}$

Uma forma de dar conta entre dados e teoria seria interpretar que há, pelos menos, duas "fases" na queda de sílaba:

- 1a fase: verificar se a cavidade oral das consoantes, isto é, o ponto de C e [ \pm contínuo], é a mesma (nó B);

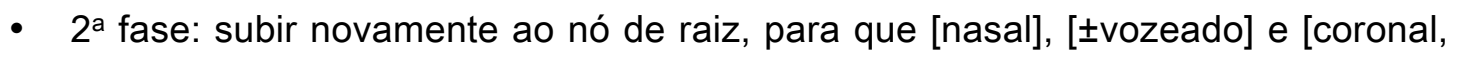
dorsal e labial] possam atuar com favorecimento, neutralidade ou desfavorecimento.

Esquematicamente, temos que o local de aplicação da regra é na cavidade oral (em vermelho) e os traços que ditam as tendências estão circulados (em azul):

\footnotetext{
110 Não discutimos os traços [anterior, distribuído] das coronais porque estes contextos tiveram pouca ocorrência neste trabalho. No entanto, uma vez que estes traços são dominados por [coronal] e, mais acima, por ponto de C e cavidade oral, uma hipótese a ser checada é que deve haver igualdade em [anterior, distribuído] nas consoantes para que o processo aconteça; se estes traços forem diferentes nas coronais, a hipótese é que o processo é bloqueado - da mesma forma que pudemos concluir do nó de cavidade oral.
} 


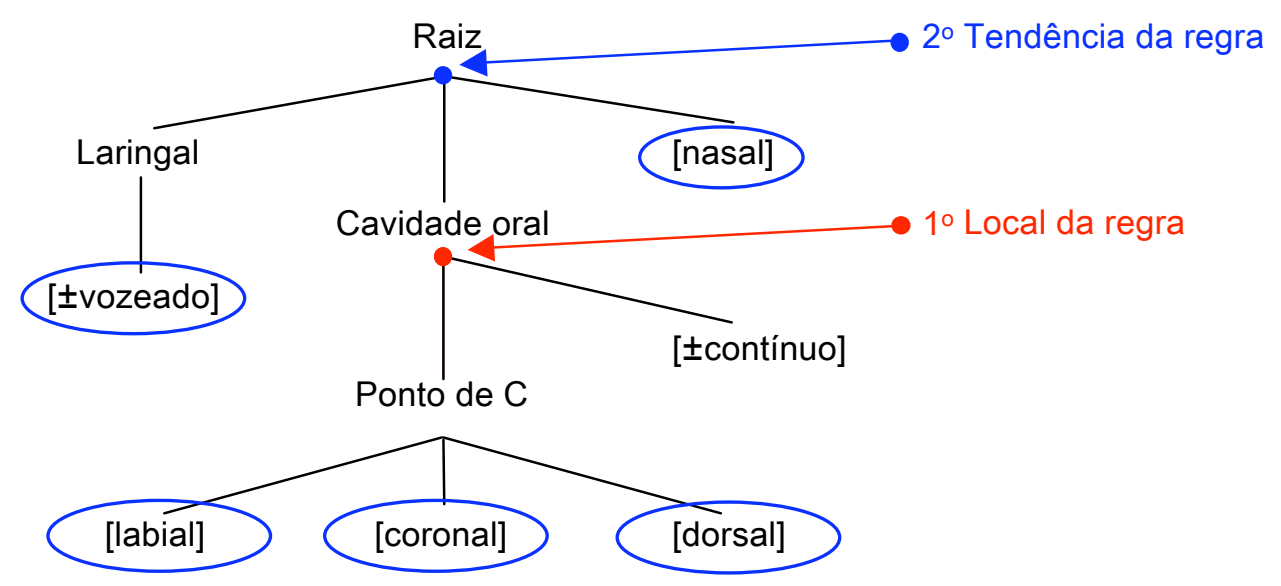

Gráfico 40-Geometria dos nós: raiz, laringal e cavidade oral (adaptado de Clements \& Hume 1995: 292)

No entanto, esta interpretação de duas "fases" contraria o princípio de que regras fonológicas executam uma única operação (Clements \& Hume 1995: 250), pois a queda de sílaba identifica primeiro a cavidade oral (local da regra, em vermelho no gráfico) e sobe novamente ao nó de raiz, para que os traços circulados no Gráfico 40 ditem favorecimento, neutralidade ou desfavorecimento. Esta interpretação vai de encontro também ao princípio de que, se um processo fonológico é aplicado num determinado nó, aplica-se também a todos os seus nós dominados (cf. Clements \& Hume 1995: 251): na segunda fase, em que o processo "retorna" ao nó de raiz para determinar a tendência do processo, deve-se ignorar [ \pm contínuo], pois este traço determina a possibilidade de aplicação ou o bloqueio nunca a tendência.

Em vista do que apresentamos nesta subseção, vemos que há ainda uma grande dificuldade em capturar a queda de sílaba. Por outro lado, estudos sobre este processo fonológico podem contribuir para a teoria fonológica. 


\section{CAPÍTULO X}

\section{Conclusão}

Esta pesquisa teve como início aplicações de queda de sílaba que são peculiares a capivarianos, e que são rejeitadas por campineiros. Por exemplo, dos outputs:

(295) [na.,ka.de.'mi.a] [na.'ka.de.'mi.a]

vimos que pode haver dois inputs /na.a.,ka.de.'mi.a/ > n[a]cademia ou /na.'ka.za.de.'mi.a/ > na ca(sa) de Mia em Capivari, mas /na.'ka.za.de.'mi.a/ > *na ca(sa) de Mia é uma interpretação impossível em Campinas.

Com base nesta diferença, o principal objetivo desta tese foi verificar se a implementação da queda de sílaba é igual ou diferente nos dialetos de Capivari e de Campinas. Interessantemente, o contexto segmental $/ z+d /$ foi descartado como contexto para aplicação do processo logo no estudo piloto, pois veio a ser um contexto de exceção de queda de sílaba (cf. resultados do estudo piloto em 5.1).

$\mathrm{Na}$ rodada Geral, vimos que a variável Cidade não foi selecionada, de onde concluiríamos que não há interferência se o falante é capivariano ou campineiro - ou seja, Capivari e Campinas teriam uma mesma regra de aplicação de queda de sílaba. Porém, partindo das frequências de aplicação do processo nas duas cidades, um segundo exame apontou que Capivari e Campinas aplicam o processo de modo diferente; assim, com base nestes resultados, computamos as duas cidades separadamente, a fim de analisar mais profundamente quais são as diferenças entre as duas cidades.

Pudemos concluir que propriedades segmentais, suprassegmentais e lexicais são diferentes em Capivari e Campinas. Na primeira subseção deste capítulo, apresento as constatações gerais desta tese e, na subseção seguinte, apresento pistas para trabalhos a serem desenvolvidos - sugestões motivadas pelos resultados que encontramos. 


\subsection{Do que foi constatado}

Nesta subseção, apresento os resultados que corroboram a literatura sobre o assunto e também aqueles que foram encontrados pela primeira vez nesta tese.

Com relação ao contexto consonantal, concluímos que há possibilidade de queda de sílaba com segmentos diferentes de /t/ e /d/, o que corrobora Pavezi (2006a) (para haplologia) e Leal (2006) (para a queda de sílaba) - chamamos a atenção para o fato de que utilizamos ferramentas estatísticas, diferentemente das metodologias empregadas por Pavezi (2006a) e Leal (2006).

Ainda para os traços consonantais, constatamos que capivarianos e campineiros têm tendências idênticas com relação ao ponto de C [coronal] (de consoantes orais) e ao traço [nasal]: as coronais orais favorecem o processo (sem importar os valores para [contínuo]), enquanto que nasais desfavorecem. No caso das nasais, vimos que Pavezi (2006a) verificou que estas consoantes permitem a haplologia; os dados de Leal (2006) resultaram que a queda de sílaba (elisão silábica e haplologia) também pode ser aplicada com nasais, mas há uma exceção nos testes, sequências [nasal + oral] - cf. descrição dos trabalhos sobre as nasais nas subseções 3.2.1, 3.3 e 4.1.4.1.1.3. Dos resultados desta tese, vimos que ambas as cidades preferem uma configuração em que estes segmentos são levados em conta, já que, nas rodadas Geral, em Capivari e em Capivari, só foram selecionadas as variáveis em que este traço foi examinado em separado. $\mathrm{Na}$ variável Cavidade Oral das Consoantes com Distinção de [nasal], pudemos concluir que este é um traço que interfere na regra, no sentido de desfavorecer o processo, nos dois dialetos estudados. Entretanto, as cavidades orais das consoantes não são iguais em Capivari e Campinas porque as cidades divergem no traço [dorsal]: há um favorecimento do processo entre os capivarianos, e um desfavorecimento entre os campineiros.

Quanto ao traço [vozeamento], corroboramos a literatura em dois pontos. Primeiramente, este traço não bloqueia o processo, o que corrobora Alkmim \& Gomes (1982), de Lacy (1999), Tenani (2002), Pavezi (2006a) e Leal (2006), dentre outros. Em segundo lugar, encontramos um resultado que revela que, se as consoantes forem diferentes em [vozeamento], há uma neutralidade ao processo. No entanto, se as consoantes forem idênticas, isto é, os contextos consonantais forem iguais em 
[vozeamento], o processo é favorecido. Em outras palavras, pudemos nos certificar com ferramentas estatísticas de que o traço [vozeamento] interfere na queda de sílaba se ambas as consoantes tiverem o mesmo valor para este traço, de modo a favorecer o processo.

No que concerne ao contexto vocálico, pudemos observar que não há bloqueio com vogais dorsais, o que corrobora Pavezi (2006a) e Leal (2006). Este resultado vai de encontro à proposta de Alkmim \& Gomes (1982), para quem só há haplologia com vogais [+alto]; interessantemente, contextos com vogais dorsais desfavorecem o processo em ambas as cidades. Da Cavidade Oral das Vogais, pudemos constatar que houve: (i) diferenças: nos contextos com duas coronais e com uma dorso-labial seguida de uma coronal, há um favorecimento em Campinas e uma neutralidade em Capivari; (ii) semelhanças: contextos em que há uma coronal seguida de uma dorsal favorecem o processo nos dois dialetos, e a tendência é maior em Capivari; outra semelhança diz respeito aos contextos com dorsais, já que há um desfavorecimento nas duas cidades, e os capivarianos aceitam mais o apagamento com estes contextos do os campineiros; e (iii) igualdades: há favorecimento do processo, com pesos relativos próximos, nas sequências com duas dorso-labiais e nos contextos de uma dorso-labial seguida de uma dorsal em ambas as cidades. Um resultado interessante está relacionado a vogais iguais versus diferentes: pudemos verificar que a igualdade destes segmentos não é relevante para aplicação da queda de sílaba, mas sim qual é o traço da vogal sujeita ao apagamento: duas coronais no contexto de queda e duas dorso-labiais favorecem, enquanto que duas dorsais desfavorecem - portanto, a igualdade das vogais não é relevante, mas sim o ponto de $C$ da vogal sujeita ao apagamento.

Para as Estruturas das Sílabas do contexto de queda, houve variação com estruturas CCV na primeira posição, ou seja, não há bloqueio do processo com sílabas de ataque ramificado, resultado que vai de encontro aos de Alkmim \& Gomes (1982), e corrobora Battisti (2004), Pavezi (2006a) e Leal (2006). Foi verificado também que estruturas CCV parecem não interferir no processo, pois os resultados indicam uma neutralidade da queda de sílaba. Concluímos também que sílabas que tenham estruturas com coda CVC na primeira sílaba desfavorecem o processo em ambas as cidades. Assim como para vogais, verificamos nesta variável que é a estrutura da sílaba sujeita à queda (e 
não a igualdade entre elas) que dita se há um maior ou menor favorecimento em ambas as cidades.

Da variável Métrica, os resultados são semelhantes nas duas cidades: há um favorecimento nos contextos originais de uma sílaba forte seguida de uma fraca e um clítico [ $\mathrm{x} \cdot \# \mathrm{c}$ ] e de uma sílaba forte seguida de uma fraca e um acento secundário [ $\mathrm{x} \cdot \# \mathrm{y}$ ]; há uma neutralidade em contextos de uma sílaba forte seguida de duas fracas $[\mathrm{x} \bullet \# \cdot$ ]; e há um desfavorecimento se o contexto original resultar em choque acentual depois da aplicação do processo $[\mathrm{x} \cdot \# \mathrm{x}]$.

Com relação às variáveis Igualdade de Segmentos, Número de Sílabas e Frequência de Uso da Palavra Sujeita ao Apagamento, os resultados para as duas cidades foram diferentes, já que estas variáveis foram selecionados apenas em uma delas. Ao examinar o contexto segmental como uma gradação de sílabas com segmentos iguais versus sílabas com segmentos diferentes, foi verificado que só há efeito de Igualdade de Segmentos para os campineiros (a variável não foi selecionada em Capivari). Em Campinas, se as consoantes forem idênticas, há uma maior aplicação; se as consoantes variarem em vozeamento, há uma neutralidade; por fim, se a diferença consonantal for a nasalidade, há um desfavorecimento, o que corrobora os achados da variável Cavidade Oral das Consoantes com Distinção de [nasal] - vimos que este traço desfavorece o processo. O tamanho fonológico (variável Número de Sílabas) é importante na aplicação do processo, também a depender do dialeto: a variável foi selecionada em Capivari, mas não em Campinas. Em Capivari, vimos que dissílabos desfavorecem (levemente) o processo, trissílabos são neutros e palavras de mais de quatro sílabas favorecem um pouco a queda de sílaba. Com base nestes resultados, interpretamos que a informação pode ser mais facilmente recuperada pelo ouvinte se a palavra sujeita à queda for maior.

A variável Frequência de Uso da Palavra Sujeita ao Apagamento não é importante no dialeto capivariano, enquanto que os campineiros levam em conta se é uma palavra de média frequência (que favorece o processo) e de baixa frequência (desfavorecendo a queda de sílaba), enquanto que há uma neutralidade se a palavra for de alta frequência.

Vimos que o efeito da Prosódia é idêntico nas duas cidades: há uma neutralidade em fronteira entre grupos clíticos, o processo é inibido entre sentenças e é favorecido na 
fronteira entre duas frases fonológicas - este resultado da relação entre queda de sílaba e frase fonológica corrobora Battisti (2004), Pavezi (2006a) e Leal (2006): as autoras sustentam que este é o nível mais favorável à haplologia (especificamente, também para a elisão silábica em Leal 2006).

Dentre as variáveis externas, vimos que a variável Gênero tem um mesmo comportamento nos dois dialetos: em Capivari, os homens aplicaram 1,662 vezes mais do que as mulheres; em Campinas, os homens aplicaram 1,656 vezes mais do que as mulheres. Quanto à Escolaridade e Faixa Etária dos falantes, houve um comportamento diferente nas duas cidades. Para Escolaridade, campineiros com menos anos de estudo aplicam mais a queda de sílaba do que campineiros que cursaram faculdade; e em Capivari, não há diferença se o informante estudou até o ensino fundamental ou até o ensino superior. Para a Faixa Etária, capivarianos mais jovens aplicam mais do que capivarianos mais velhos; e, em Campinas, as porcentagens foram praticamente as mesmas nos fatores de 20 a 35 anos e de mais de 50 anos de idade.

Assim, concluímos que as cidades têm regras diferentes de aplicação de queda de sílaba.

\subsection{Das pistas encontradas: continuação de estudos}

Nesta tese, pudemos nos certificar de que os dialetos de Capivari e de Campinas têm regras diferentes no que concerne à queda de sílaba. O presente trabalho pode abrir portas a novos estudos: a identificação e a descrição da queda de sílaba em trabalhos futuros pode ampliar a investigação do processo, com base nos resultados encontrados nesta tese.

Nesta subseção, apresento pistas encontradas nesta pesquisa que podem servir de base a outros trabalhos.

Para o contexto segmental, partimos da proposição de que a sílaba é o alvo do processo fonológico, mas o que determina se o apagamento ocorre ou é bloqueado é o nível segmental, as consoantes. Foi importante separar consoantes e vogais neste estudo, de onde pudemos comprovar que estas duas classes fonológicas têm papéis diferentes na implementação da regra: as consoantes definem o processo, já que se deve levar em conta 
traços internos a estes segmentos; quanto às vogais, a importância é que ditam a produtividade do processo, e não o bloqueiam. Um outro modo de se analisar o contexto segmental seria unir sílaba 1 + sílaba 2 , ou seja, colocar os segmentos das sílabas $\mathrm{C} 1 \mathrm{~V} 1+\mathrm{C} 2 \mathrm{~V} 2$ numa única variável, com o objetivo de responder à seguinte questão: há um favorecimento à queda se todos os segmentos do contexto tiverem um mesmo ponto de $C$ ? Por exemplo, uma hipótese seria que, em sequências de segmentos [ $\mathrm{C} 1$ coronal $\mathrm{V} 1$ coronal + $\mathrm{C} 2$ coronal $\mathrm{V} 2$ coronal ], há uma maior propensão ao processo.

Um resultado interessante foi que são as características da sílaba que ocupa a primeira posição no contexto que parece ser importante na queda de sílaba, e não a igualdade/diferença entre as unidades. Estes resultados foram obtidos nas variáveis de Cavidade Oral das Vogais e de Estrutura Silábica: não importam as semelhanças/ diferenças entre as duas vogais/estruturas das sílabas, mas sim quais são as características da vogal/estrutura sujeita à queda. Com relação a [vozeamento], os resultados apontam que, se as consoantes forem diferentes neste traço, o processo é neutro; e se as consoantes forem idênticas (ou seja, tiverem o mesmo valor para [vozeamento]), há um leve favorecimento da queda de sílaba. No entanto, não verificamos como a sucessão destes traços nas sílabas podem interferir no processo, como ocorre com as vogais e estrutura das sílabas. Assim, um tema a ser considerado em trabalhos futuros é examinar como as combinações entre consoantes [ \pm vozeado] podem interferir no processo, respondendo a questões como: (i) Há alguma diferença na aplicação do processo se as consoantes forem [+vozeado] + [-vozeado] ou [-vozeado] + [+vozeado]? (ii) Se a igualdade em [vozeamento] favorece, há alguma diferença se as consoantes forem [+vozeado] + [+vozeado] ou [-vozeado] + [-vozeado]? (iii) Assim como os resultados encontrados para vogais e para estruturas das sílabas, o que deve ser levado em conta é o vozeamento da primeira consoante ou a igualdade deste traço entre as consoantes?

No que concerne à Métrica, vimos que contextos originais $[\mathrm{x} \cdot \# \mathrm{x}]$ que resultam em choque de acento com a aplicação de queda de sílaba são desfavorecedores, enquanto que uma sílaba forte seguida de uma fraca e um clítico $[x \cdot \# c]$ são favorecedores. No entanto, contextos com uma sílaba forte seguida de duas fracas [ $\mathrm{x}$ - $\cdot$ ] deveriam se comportar linguisticamente de modo semelhante à sequência $[x \cdot \# c]$ (favorecendo a queda 
de sílaba, e não resultando em neutralidade, como pudemos verificar), enquanto que contextos $[x \cdot \# y]$ deveriam ter resultados parecidos com $[x \cdot \# x]$, inibindo o processo (e não favorecendo-o, como resultaram estes dados). Interpretamos estes dados da seguinte maneira (cf. subseção 9.1): (i) ou a hierarquia de acentos deve ser revista, considerando que há apenas uma acento forte (o primário) e todos os outros graus são fracos; (ii) ou a aplicação de queda de sílaba leva em conta apenas o acento primário, desprezando o acento secundário e o acento de um clítico fonológico. Um tema interessante para trabalhos futuros (que relacionem a queda de sílaba à métrica) é englobar um contexto mais amplo do que o acento forte na primeira palavra seguido de uma (ou duas) sílaba(s) fraca(s) e a primeira sílaba da segunda palavra, a fim de examinar como a métrica interfere no processo, considerando-se os quatro graus de acento.

Houve algumas análises inconclusivas no presente estudo, devido à baixa frequência de tokens, quais sejam: os contextos consonantais com labiais [+contínuo] e [-contínuo] e com consoantes diferentes em [anterior, distribuído]; os dados de estruturas com sílabas CCV + CCV e CVC + CVC; e contextos em que a aplicação de queda de sílaba é possível com duas consoantes que diferem na cavidade oral. Assim, investigar estes contextos pode ser temas interessantes para trabalhos futuros.

Um fator que não foi analisado no presente estudo e que poderia ser associado à queda de sílaba é a taxa de elocução da fala. Logo no início de seu artigo, Alkmim \& Gomes (1982) afirmam que a taxa de elocução pode ser um fator importante no condicionamento da haplologia - e, de modo mais amplo, da queda de sílaba.

Com relação às variáveis externas, um trabalho a ser feito poderia discutir se a queda de sílaba é um processo socialmente marcado, já que, de acordo Labov (1972) e Guy (1981), processos fonológicos de apagamento são socialmente marcados. Observando os resultados de Escolaridade e Gênero do presente estudo (as variáveis que podem indicar se a variável dependente é socialmente marcada), uma pista de que a queda de sílaba pode ser um processo fonológico marcado está na variável Gênero, tanto em Capivari quanto em Campinas (o processo é mais aplicado por homens); quanto à Escolaridade, parece que esta interpretação de a queda de sílaba ser marcada socialmente só se sustenta em Campinas, já que as taxas para Capivari foram muito próximas. Desta 
forma, trabalhos futuros que foquem a relação entre a queda de sílaba ser ou não marcada são necessários.

Neste trabalho, pudemos responder a questões interessantes sobre a queda de sílaba, em diversos níveis fonológicos - segmental, suprassegmental e lexical.

No entanto, esta seção mostra que o trabalho está apenas começando e ainda há muitas questões a serem discutidas (algumas sugeridas aqui, outras que só se revelarão quando mais estudos forem conduzidos). 


\section{Referências Bibliográficas}

Abousalh, E.S.F. (1997). Resolução de choques de acento no português brasileiro. Tese de doutorado, Universidade Estadual de Campinas (UNICAMP), Brasil.

Alkmim, T.M.; Gomes, C. A. (1982). Dois fenômenos de supressão de segmentos em limite de palavra. Ensaios de Linguística, 7: 43-51.

Amaral, A. (1920). O dialeto caipira. Disponível em: $<$ http://www.dominiopublico.gov.br/download/texto/bi000004.pdf>. Acesso em: 08 set 2006.

Battisti, E. (2004). Haplologia sintática e efeitos da economia. Organon (UFRGS), Porto Alegre - RS, v. 18, n. 36, p. 31-39.

Brasil. Constituição (1988). Constituição da República Federativa do Brasil: promulgada em 5 de outubro de 1988. Disponível em:

<http://www.senado.gov.br/legislacao/const/con1988/CON1988_05.10.1988/CON1988 .pdf>. Acesso em: 26 mar 2012.

Bisol, L. (1989). O ditongo na perspectiva da fonologia atual. D.E.L.T.A, v. 5, n. 2, p. 185224.

(1992). O acento e o pé métrico binário. Cadernos de Estudos Linguísticos, n. 22 ed. UNICAMP 69-80 Campinas.

(1996). O sândi e a ressilabação. Letras de Hoje. Porto Alegre, Vol. 31, 2: 159-168.

(2000). O troqueu silábico no sistema fonológico (Um adendo ao artigo de Plínio Barbosa). D.E.L.T.A. Vol.16, 2: 403-13.

(2003). Sandhi in Brazilian Portuguese. Probus 15: 177-200.

Boersma, P.; Weenink, D. (2010). Praat: doing phonetics by computer (Versão 5.1.23). Disponível em: <http://www.praat.org/>. Acesso em: 24 mai 2011.

Borges Neto, J.; Müller, A. L. (1987). Linguistas ou camaleões? - Uma resposta a Tarallo. D.E.L.T.A., 3.1: 85-95.

Camacho, R. (1988). A variação lingüística. Subsídios à proposta curricular de Língua Portuguesa para o $1^{\circ}$ e $2^{\circ}$ graus. Secretaria da Educação do Estado de São Paulo, p. 29-41.

Camara Jr., J.M. (1969). Problemas de Linguística Descritiva. Petrópolis: Vozes. (1970). Estrutura da Língua Portuguesa. Petrópolis: Vozes.

Casali, R. F. (1997) Vowel elision in hiatus contexts: which vowel goes? Language 73(3): 493-528.

Chomsky, N. (1965). Aspects of the Theory of Syntax. Cambridge: The MIT Press

Chomsky, N.; Hale, M. (1968). The Sound Pattern of English. New York: Harper \& Row.

Clements, G.N.; Hume, E. (1995). 'The Internal Organization of Speech Sounds. J. Goldsmith (ed). The Handbook of Phonological Theory. Oxford: Basil Blackwell, pp. 245-306.

Clements, G.N.; Keyser, S.J. (1983). CV Phonology: a Generative Theory of the Syllable. J. A. Goldsmith (ed.) (1999) Phonological Theory: The Essential Readings. Oxford: Blackwell. 
Collischonn, G. (2007). Proeminência acentual e estrutura silábica: seus efeitos em fenômenos do português brasileiro. Gabriel Antunes de Araújo (org.) $O$ acento em português. São Paulo: Parábola.

Corbin, D; Plénat. P. (1992). Note sur l'haplologie des mots construits. In: Langue française. $\mathrm{N}^{\circ} 96,1992$. pp. 101-112.

Cristófaro-Silva, T. (1999). O Método das Vogais Cardeais e as Vogais do Português Brasileiro. Revista de Estudos da Linguagem, Belo Horizonte, v. 8, n. 2, p. 127-53.

(2001). Difusão Lexical: Estudo de Casos do Português Brasileiro. E.A.M. Mendes, P.M. Oliveira \& V. Benn-lbler (orgs). O Novo Milênio: interfaces lingüísticas e literárias. Faculdade de Letras. Belo Horizonte, pp. 209-218.

Cristófaro-Silva, T.; Oliveira, D.M.L. (2004). Efeitos da freqüência na produção de fricativas alveopalatais emergentes. Estudos Lingüísticos XXXIII, pp. 656-662.

Crystal, D. (1985). Dicionário de linguística e fonética. Trad. [da $2^{\mathrm{a}}$ ed. inglesa de 1985]: Maria Carmelita Pádua Dias (2003). Rio de Janeiro: Jorge Zahar.

De Lacy, P. (1999). Morphological haplology and correspondence. P. de Lacy; A. Nowak, (eds). University of Massachusetts Occasional Papers: Papers from the 25th Reunion. Amherst, MA: GLSA, 1999. (ROA 289).

Dicionário Priberam da Língua Portuguesa [online], 2010. Disponível em: <http://www.priberam.pt/dlpo/dlpo.aspx >. Acesso em: 07 jan 2012.

Feagin, C. (2002). Entering the Community: fieldwork. Handbook of Language Variation and Change. J. K. Chambers, Peter Trudgill \& Natalie Schilling-Estes (eds.), 20-39.

Fikkert, P.; Levelt, C. (2006). How does Place fall into Place? The lexicon and emergent constraints in children's developing phonological grammar. Manuscript January 2006.

Françozo, E.; Oliveira, L.F.; Ruiz, L.G.; Lima, P.L.C; Navas, A.L.G.P. (2002). Conhecimento Lexical e Processamento da Linguagem. Reunião Anual do GEL, 2002, São Paulo. Anais da $25^{a}$ Reunião Anual do GEL. São Paulo: GEL.

Frota, S. (1995). Os domínios prosódicos e o português europeu: fenómenos de sandhi. Actas do $10^{\circ}$ Encontro Nacional da APL. Évora, 1994, pp. 221-238.

Fudge, E. (1999). Words and feet. Journal of Linguistics 35.2, pp.273-296.

Galves, C.; Abaurre, M.B.M. (1996) Os clíticos no português brasileiro: elementos para uma abordagem sintático-fonológica. A.T. Castilho; M. Basílio (orgs.). Gramática do português falado. Vol IV. Campinas: Ed. Unicamp.

Garcia R.R. (2009a). Para o estudo de formação e expansão do dialeto caipira em Capivari. Dissertação de mestrado. São Paulo: DLCV-USP.

(2009b). Para o estudo de formação e expansão do dialeto caipira em Capivari. Estudos Linguísticos, São Paulo, 38 (2): 43-57.

(1990). Autosegmental and Metrical Phonology. Oxford: Blackwell.

(2011). The Syllable. J. Goldsmith, J. Riggle and A. C. L. Yu. The Handbook of Phonological Theory, Second Edition (eds). Oxford, UK: Wiley-Blackwell.

Gouskova, M. (2003). Deriving economy: syncope in Optimality Theory. Ph.D. Dissertation. University of Massachusetts, Amherst.

Grammont, M. (1933). Traité de Phonétique. Paris: Librairie Delagrave.

Guy, G.R. (1981). Linguistic Variation in Brazilian Portuguese: Aspects of the Phonology, Syntax, and Language History. Ph.D. Dissertation. University of Pennsylvania. 
(1988). Varbrul: análise avançada. [Trad. Ana Zilles] In: Guy, G.; Zilles, A. (2007). Sociolinguística quantitativa: Instrumental de análise. São Paulo: Parábola Editorial.

Guy, G.R.; Bisol, L. (1991). A teoria fonológica e a variação. Organon, v. 5, n. 18, p.126-36.

Guy, G.; Zilles, A. (2007). Sociolinguística quantitativa: Instrumental de análise. São Paulo: Parábola Editorial.

Hayes, B. (1989). The Prosodic Hierarchy in meter. Paul Kiparsky and Gilbert Youmans, eds., Rhythm and Meter, Academic Press, Orlando, FL, pp. 201-260.

(1995). Metrical Stress Theory: Principles and Case Studies. Chicago: University of Chicago Press.

(2009). Introductory Phonology. Malden: Blackwell.

Hock, H. H. (1991). Principles of Historical Linguistics. Berlin, New York: Mouton de Gruyter.

Honeybone, P. (2011). Variation and linguistic theory. W. Maguire \& A. McMahon (eds.) Analysing variation in English. Cambridge: Cambridge University Press, 151-77.

IBGE (Instituto Brasileiro de Geografia e Estatística). Disponível em: <http://www.ibge.gov.br/home/>. Acesso em: 3 de abr 2011.

Jakobson, R.; Fant, C.G.M.; Halle, M. (1952). Preliminaries to speech analysis: the distinctive features and their correlates. Cambridge, Mass.: MIT Press.

Labov, W. (1972). Sociolinguistic Patterns. Philadelphia: University of Pensilvania Press. (1990). The intersection of sex and social class in the course of linguistic change. Language Variation and Change 2, 205-254.

(1994). Principles of linguistic change, vol. I, Internal factors. Malden and Oxford: Blackwell Publishers.

(2001). Principles of linguistic change, vol. II, Social factors. Malden and Oxford: Blackwell Publishers.

Ladefoged (2003). Phonetic data analysis: An introduction to fieldwork and instrumental techniques. Oxford: Blackwell.

(2006). A Course in Phonetics. (5 $5^{\text {th }}$ ed.). Boston: Heinle \& Heinle.

Lawrence, W.P. (1998). Haplology and vowel underspecification. Report of the special research project for the typological investigation of the languages and cultures of the east and west, 381-8.

Leal, E.G. (2006). Elisão silábica e haplologia: aspectos fonológicos do falar da cidade paulista de Capivari. Dissertação de mestrado. São Paulo: FFLCH-USP.

(2007). A queda da sílaba: análise do contexto consonantal pela geometria de traços. Revista Virtual de Estudos da Linguagem - ReVEL. Edição especial n. 1. Disponível em: <www.revel.inf.br>.

Leal, E.G.; Santos, R.S. (2010). Post-tonic syllables and prosodic boundaries in Brazilian Portuguese. Proceedings of the 5th International Conference Speech Prosody 5th International Conference Speech Prosody, 2010, Chicago.

Leben, W. (1973). Suprasegmental Phonology. Ph.D. Dissertation. MIT: Cambridge, Massachusetts.

Lee, S-H. (1994): A Regra do Acento do Português: Outra Alternativa. Letras de Hoje 98, PUC-RS, v. 98, p. 43-53.

(1999). Sobre a Formação de Diminutivo do Português Brasileiro. Revista de Estudos da Linguagem, Belo Horizonte, v. 8, n. 1, pp. 113-23. 
Leite, Cândida M.B. (2004). Atitudes linguísticas: a variante retroflexa em foco. Doutorado em Linguística. Tese de doutorado, Universidade Estadual de Campinas (UNICAMP), Brasil.

(2005). O /r/ em coda silábica no dialeto campineiro. IV Congresso Internacional da ABRALIN, Brasília. IV Congresso Internacional da ABRALIN. v. 1. pp. 102-4.

(2011). Estudo do /r/ em coda silábica medial e final no falar campineiro. VII Congresso Internacional da ABRALIN, Curitiba. Anais do VII Congresso Internacional da Abralin.

Liberman, M. \& Prince, A. (1977). On stress and linguistic rhythm. Linguistic Inquiry 8:249336.

Malamud, S.A. (2004). 'The puzzle of language change'. Disponível em: <http://www.ling.upenn.edu/courses/Summer_2004/ling001/lecture7.html>.

Massini-Cagliari, G. (1995). Cantigas de amigo: do ritmo poético ao lingüístico - um estudo do percurso histórico da acentuação em Português. Doutorado em Linguística. Universidade Estadual de Campinas, UNICAMP.

Mattos e Silva, R.V. (2004). Ensaios para uma sócio-história do português brasileiro. São Paulo: Parábola.

McBride, A.I. (2004). A Constraint-Based Approach to Morphology. PhD Dissertation. University of California, Los Angeles.

McCarthy, J. (1979). On stress and syllabification. Linguistic Inquiry 10: 443-465. (1986): OCP effects: gemination and antigemination. Linguistic Inquiry 17, pp.20763.

(1988). Feature geometry and dependency: A review. Phonetica 45: 84-108.

Menn, L. \& McWhinney, B. (1984). The Repeated Morph Constraint: toward an Explanation. Language 60, 519-541.

Mercado, A. (2001). Phonology and poetics: The Problem of Greek amphiphoreús and amphoreús. Presented at the American Philological Association Annual Meeting, San Diego, Ca, Jan. 4, 2001.

Miller, P. (1992): Clitics and Constituents in Phrase Structure Grammar. New York, London: Garland Publishing, Inc.

Mollica, M. C.; Roncarati, C. (2001). Questões teórico-descritivas em Sociolinguística e em Sociolinguística Aplicada e uma proposta de agenda de trabalho. D.E.L.T.A., São Paulo, v. 17, Edição especial.

Neeleman, A. \& Koot, H. (2005). Syntactic OCP effects. The Blackwell syntactic companion, edited by M. Everaert and Henk van Riemsdijk. London: Blackwell.

Nespor, M. \& Vogel, M. (1986): Prosodic phonology. Dordrecht: Foris Publications.

Nunes, J.; Santos, R.S. (2009). Stress shift as a diagnosis for identifying empty categories in Brazilian Portuguese. Jairo M. Nunes. (Org.). Minimalist Essays in Brazilian Portuguese Syntax. John Benjamins.

Oliveira, M.A. (1992). Aspectos da difusão lexical. Rev. Est. Ling., Belo Horizonte, ano 1, v.l, p. 31-41.

Ortmann, A.; Popescu, A. (2000). Haplology involving morphologically bound and free elements: Evidence from Romanian. J. van Marle and G. Booij (eds). Yearbook of morphology 2000, 43-70. Dordrecht: Kluwer. 
Pagotto, E.G. (2004). Variação e (') identidade. Maceió: EDUFAL.

Paradis, C.; Prunet, J.F. (1991). Phonetics and Phonology: The Special Status of Coronals. Vol. 2. San Diego: Academic Press.

Pavezi, V.C. (2006a). A haplologia na variedade paulista. Dissertação de mestrado. São José do Rio Preto: Unesp.

(2006b). Haplologia entre fronteiras acima da palavra fonológica. Estudos Linguísticos XXXV, pp. 1945-51.

Plag, I. (1998). Morphological haplology in a constraint-based morpho-phonology. W. Kehrein and R. Wiese (eds.) Phonology and Morphology of the Germanic Languages. 199-215. Tübingen: Niemeyer.

PNUD (Programa das Nações Unidas para o Desenvolvimento). "Entenda o cálculo do IDH Municipal (IDH-M)". Disponível em: <www.pnud.org.br/atlas/PR/Calculo_IDH.doc>. Acesso em: 26 mar 2012.

Prefeitura Municipal de Campinas. Disponível em: <http://www.campinas.sp.gov.br/>. Acesso em: 3 abr 2011.

Prefeitura Municipal de Capivari. Disponível em: <http://www.capivari.sp.gov.br/>. Acesso em 3 abr 2011.

Russel, K. (1999). MOT: sketch of an OT approach to morphology. MS, University of Manitoba.

Sá Nogueira, R. (1958). Tentativa de Explicação dos Fenômenos Fonéticos em Português. Lisboa: Livraria Clássica Editora.

Sagey, E.C. (1986). The representation of features and relations in non-linear phonology. $\mathrm{PhD}$ thesis. MIT, Cambridge.

Sankoff, D.; Tagliamonte, S.; Smith, E. (2005). Goldvarb X: A variable rule application for Macintosh and Windows. Department of Linguistics, University of Toronto.

Sandalo, M. F.; Abaurre, M. B. M. (2007). Acento secundário em duas variedades do português. G.A. Araújo (ed.). $O$ acento em português: abordagens fonológicas. São Paulo: Parábola Editorial. pp. 145-67.

Santos, R. S. (2002). Categorias Sintáticas Vazias e Retração de Acento em Português Brasileiro. Documentação de Estudos em Lingüística Teórica e Aplicada, D.E.L.T.A. São Paulo, v. 18, n. 1, p. 67-86.

(2003a). Traces, pro and Stress Shift in Brazilian Portuguese. Journal of Portuguese. Linguistics, Portugal, v. 2, n. 2, pp. 101-13. (2003b). Parasitic gaps and stress retraction in Brazilian Portuguese. Prosodic Interfaces, Nantes. Proceedings of IP2003. Nantes, 2003. v. I. pp. 307-12.

(2007). A aquisição prosódica do português brasileiro de 1 a 3 anos. Tese de Livredocência. FFLCH-USP, São Paulo.

(2009). Segmental and Prosodic Aspects in the Acquisition of Elision in Brazilian Portuguese. In: Boston University Conference on Language Development, 2009, Boston. Proceedings of the 33rd annual Boston University Conference on Language Development. Somerville, MA: Cascadilla Press, v. 2., pp. 456-67.

Sasaki, K. (2008). Syllable deletion as a prosodically conditioned derived environment effect (2008/11/10 version). [Manuscript] 18th Japanese/Korean Linguistics Conference. The City University of New York, Nov. 13-15, 2008. 
Schwindt, L.C.S.; Quadros, E.S.; Toledo, E.E.; Gonzalez, C.A.A. (2007). A influência da variável escolaridade em fenômenos fonológicos variáveis: efeitos retroalimentadores da escrita. Revista Virtual de Estudos da Linguagem - ReVEL. Vol. 5, n. 9.

Selkirk, E.O. (1982). The syllable. H. van der Hulst \& N. Smith (eds). The structure of phonological representations. Foris Publications.

(1984). Phonology and Syntax: the relation between sound and structure. Cambridge, Mass: MIT Press.

Stemberger, J.P. (1981). Morphological haplology. Language 57: 791-817.

Tagliamonte, S.A. (2006). Analysing Sociolinguistic Variation. Cambridge: Cambridge University Press.

Tarallo, F. (1983) Zelig: um camaleão linguista. D.E.L.T.A. - Vol. 2, 1, pp. 127-44. (1991). Reflexões sobre o conceito de mudança linguística. Organon 18:11-22.

Tenani, L.E. (2002). Domínios prosódicos no português do Brasil: implicações para a prosódia e para a aplicação de processos fonológicos. Tese de doutorado. Campinas, Unicamp.

(2003). Haplologia e domínios prosódicos. Letras de Hoje, Porto Alegre: Edipucrs. (2006). Considerações sobre a relação entre processos de sândi e ritmo. Estudos da Língua(gem), Vitória da Conquista, v. 03, p. 105-122.

Veloso, B. S. (2003). A elisão de monomorfemas em casos de sândi vocálico externo em três variedades do português. Dissertação de Mestrado - Instituto de Estudos da Linguagem, Universidade Estadual de Campinas.

Weinreich, U.; Labov, W. \& Herzog, M. (1968). Empirical foundations of a linguistic theory of change. W. Lehmann; Y. Malkiel (eds.). Directions for historical linguistics. Austin: University of Texas Press.

Wetzels, L. (1997). The Lexical Representation of Nasality in Brazilian Portuguese. Probus, 9.2: 203-232.

(2000). Comentários sobre a estrutura fonológica dos ditongos nasais no Português do Brasil. Revista de Letras (UFC) no. 22, vol.1/2: 25-30.

(2007). Primary Stress in Brazilian Portuguese and the Quantity Parameter. Journal of Portuguese Linguistics. Vol 5/6, Special Issue on the Prosody of the Iberian Languages: 9-58.

Yip, M. (1998). Identity avoidance in phonology and morphology. In: Morphology and its relation to Phonology and Syntax, Steven LaPointe, Diane Brentari and Patrick Farrell (eds.), 216-246. Stanford: CSLI Publications. 


\section{Anexos}

Anexo I: Características dos Informantes

\begin{tabular}{|c|c|c|c|c|c|}
\hline número & Capivari & Campinas & Escolaridade & Gênero & Faixa Etária \\
\hline 1 & $a$ & $\mathrm{~m}$ & ensino fundamental & feminino & mais de 50 anos \\
\hline 2 & $\mathrm{~b}$ & $\mathrm{n}$ & ensino fundamental & feminino & mais de 50 anos \\
\hline 3 & $\mathrm{C}$ & 0 & ensino fundamental & feminino & mais de 50 anos \\
\hline 4 & $d$ & $\mathrm{~s}$ & ensino fundamental & masculino & mais de 50 anos \\
\hline 5 & $\mathrm{e}$ & $\mathrm{t}$ & ensino fundamental & masculino & mais de 50 anos \\
\hline 6 & $f$ & $\mathrm{u}$ & ensino fundamental & masculino & mais de 50 anos \\
\hline 7 & $g$ & $p$ & ensino superior & feminino & mais de 50 anos \\
\hline 8 & $\mathrm{~h}$ & $q$ & ensino superior & feminino & mais de 50 anos \\
\hline 9 & $\mathrm{i}$ & $r$ & ensino superior & feminino & mais de 50 anos \\
\hline 10 & $j$ & $\mathrm{v}$ & ensino superior & masculino & mais de 50 anos \\
\hline 11 & $\mathrm{k}$ & $x$ & ensino superior & masculino & mais de 50 anos \\
\hline 12 & 1 & $z$ & ensino superior & masculino & mais de 50 anos \\
\hline 13 & A & $\mathrm{M}$ & ensino fundamental & feminino & de 20 a 35 anos \\
\hline 14 & $\mathrm{~B}$ & $\mathrm{~N}$ & ensino fundamental & feminino & de 20 a 35 anos \\
\hline 15 & $\mathrm{C}$ & $\mathrm{O}$ & ensino fundamental & feminino & de 20 a 35 anos \\
\hline 16 & $\mathrm{D}$ & S & ensino fundamental & masculino & de 20 a 35 anos \\
\hline 17 & $E$ & $\mathrm{~T}$ & ensino fundamental & masculino & de 20 a 35 anos \\
\hline 18 & $\mathrm{~F}$ & $U$ & ensino fundamental & masculino & de 20 a 35 anos \\
\hline 19 & $G$ & $\mathrm{P}$ & ensino superior & feminino & de 20 a 35 anos \\
\hline 20 & $\mathrm{H}$ & $Q$ & ensino superior & feminino & de 20 a 35 anos \\
\hline 21 & 1 & $\mathrm{R}$ & ensino superior & feminino & de 20 a 35 anos \\
\hline 22 & $\mathrm{~J}$ & $\mathrm{~V}$ & ensino superior & masculino & de 20 a 35 anos \\
\hline 23 & $\mathrm{~K}$ & $x$ & ensino superior & masculino & de 20 a 35 anos \\
\hline 24 & $\mathrm{~L}$ & Z & ensino superior & masculino & de 20 a 35 anos \\
\hline
\end{tabular}


ANEXO II: Frequências do Estudo Piloto para a Cavidade Oral das Consoantes

\begin{tabular}{|c|c|c|c|}
\hline sílaba 1 & sílaba 2 & $\mathrm{~N}$ & \%apl \\
\hline dorsal, labial & coronal [+contínuo] & $0 / 1$ & 0 \\
\hline labial [+contínuo] & dorsal & $1 / 33$ & 3 \\
\hline labial [+contínuo] & coronal [-contínuo] & $0 / 79$ & 0 \\
\hline laringal & labial [-contínuo] & $0 / 3$ & 0 \\
\hline laringal & coronal [+contínuo] & $0 / 3$ & 0 \\
\hline laringal & coronal [-contínuo] & $0 / 5$ & 0 \\
\hline dorsal & labial [+contínuo] & $0 / 58$ & 0 \\
\hline dorsal & laringal & $0 / 4$ & 0 \\
\hline dorsal & coronal [+contínuo] & $4 / 54$ & 7,4 \\
\hline labial [-contínuo] & laringal & $0 / 5$ & 0 \\
\hline labial [-contínuo] & coronal [+contínuo] & $0 / 49$ & 0 \\
\hline coronal [+contínuo] & dorsal, labial & $0 / 7$ & 0 \\
\hline coronal [+contínuo] & dorsal & $0 / 303$ & 0 \\
\hline coronal [+contínuo] & labial [-contínuo] & $0 / 289$ & 0 \\
\hline coronal [-contínuo] & labial [+contínuo] & $0 / 116$ & 0 \\
\hline coronal [-contínuo] & laringal & $0 / 16$ & 0 \\
\hline \multicolumn{2}{|c|}{ ponto de $\mathrm{C}$ diferente, [contínuo] diferente } & $5 / 1025$ & 0,5 \\
\hline labial [+contínuo] & laringal & $0 / 3$ & 0 \\
\hline labial [+contínuo] & coronal [+contínuo] & $1 / 34$ & 2,9 \\
\hline dorsal & labial [-contínuo] & $2 / 102$ & 2 \\
\hline dorsal & coronal [-contínuo] & 13/181 & 7,2 \\
\hline labial [-contínuo] & dorsal, labial & $1 / 7$ & 14,3 \\
\hline labial [-contínuo] & dorsal & $1 / 84$ & 1,2 \\
\hline labial [-contínuo] & coronal [-contínuo] & $0 / 127$ & 0 \\
\hline coronal [+contínuo] & labial [+contínuo] & $0 / 215$ & 0 \\
\hline coronal [+contínuo] & laringal & $0 / 13$ & 0 \\
\hline coronal [-contínuo] & dorsal, labial & $0 / 7$ & 0 \\
\hline coronal [-contínuo] & dorsal & $2 / 185$ & 1,1 \\
\hline coronal [-contínuo] & labial [-contínuo] & $1 / 249$ & 0,4 \\
\hline dorsal, labial & labial [-contínuo] & $0 / 2$ & 0 \\
\hline \multicolumn{2}{|c|}{ ponto de $\mathrm{C}$ diferente, [contínuo] igual } & $21 / 1209$ & 1,7 \\
\hline labial [+contínuo] & labial [-contínuo] & $4 / 49$ & 8,2 \\
\hline labial [-contínuo] & labial [+contínuo] & $0 / 53$ & 0 \\
\hline coronal [+contínuo] & coronal [-contínuo] & $21 / 617$ & 3,4 \\
\hline coronal [-contínuo] & coronal [+contínuo] & $2 / 162$ & 1,2 \\
\hline
\end{tabular}




\begin{tabular}{|c|c|c|c|}
\hline \multicolumn{2}{|c|}{ ponto de C igual, [contínuo] diferente } & $27 / 881$ & 3,1 \\
\hline dorsal, labial & dorsal & $0 / 1$ & 0 \\
\hline labial [+contínuo] & labial [+contínuo] & $7 / 24$ & 29,2 \\
\hline dorsal & dorsal, labial & $0 / 2$ & 0 \\
\hline dorsal & dorsal & $13 / 91$ & 14,3 \\
\hline labial [-contínuo] & labial [-contínuo] & $10 / 105$ & 9,5 \\
\hline coronal [+contínuo] & coronal [+contínuo] & $2 / 154$ & 1,3 \\
\hline coronal [-contínuo] & coronal [-contínuo] & $89 / 532$ & 16,7 \\
\hline \multicolumn{2}{|c|}{ ponto de C igual, contínuo igual } & $121 / 909$ & 13,3 \\
\hline \multicolumn{2}{|c|}{ total } & $174 / 4024$ & 4,3 \\
\hline
\end{tabular}

